DEPARTMENT OF THE INTERIOR

Albert B. FALL, Secretary

United States Geological Survey

George OTIS SMITH, Director

Water-Supply Paper 468

\title{
RECORDS OF WATER LEVELS IN WELLS IN SOUTHERN CALIFORNIA
}

\author{
BY \\ F. C. EBERT \\ Prepared in cooperation with \\ THE DEPARTMENT OF ENGINEERING OF THE \\ STATE OF CALIFORNIA

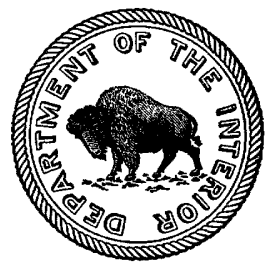 \\ WASHINGTON \\ GOVERNMENT PRINTING OFFIOE





\section{CONTENTS.}

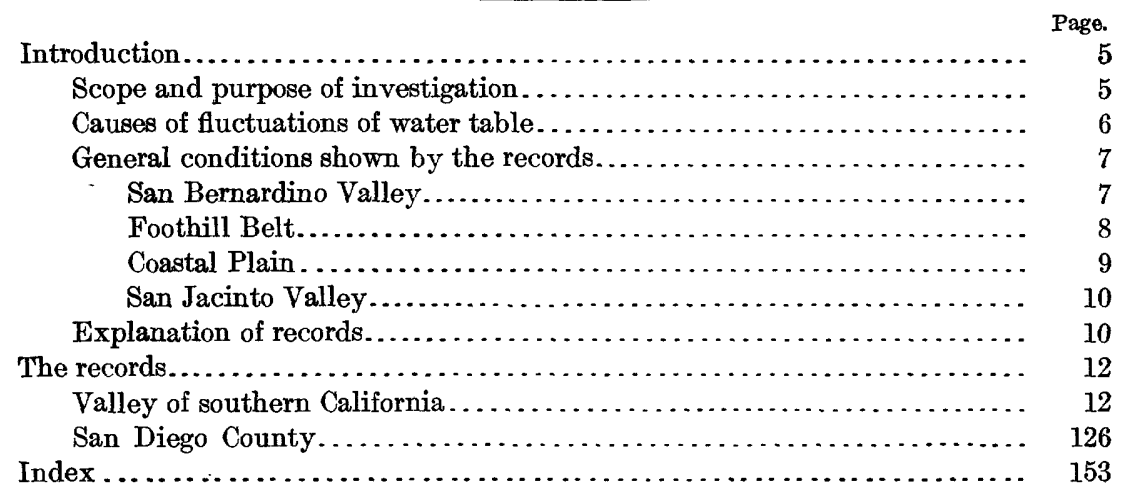

\section{ILLUSTRATIONS.}

Piate I. Map of a part of southern California showing locations of observation wells and certain precipitation and stream-gaging stations..... In pocket.

II. Graph showing fluctuation of water level in the Williams well, in San Bernardino Valley, Calif., together with precipitation at San Bernardino and discharge of Santa Ana River.................

III. Graph showing fluctuation of water level in well No.42, in the foothill belt, between Los Angeles and San Bernardino, Calif., together with precipitation at Los Angeles and discharge of San Gabriel River.

IV. Graph showing fluctuation of water level in well No. 41 (Neff well), in the Coastal Plain of southern California, together with precipitation near Tustin ......................................

Figure 1. Graph showing fluctuation of water level in well No. 72, in San Jacinto Valley, Calif., together with precipitation at San Jacinto..

Page. 



\title{
RECORDS OF WATER LEVELS IN WELLS IN SOUTHERN CALIFORNIA.
}

\author{
By F. C. EberT.
}

\section{INTRODUCTION.}

\section{SCOPE AND PURPOSE OF INVESTIGATION.}

The valley of southern California, as defined by W. C. Mendenhall," is the lowland region that is limited on the north by the San Gabriel Range and is separated from the Mohave and Colorado deserts on the east by the San Bernardino and San Jacinto mountains. Toward the west it is open to the Pacific, and on the south its. limits are irregular and to a certain degree indefinite, the lowlands gradually giving way to the highlands of San Diego County. The wells whose records of fluctuations of water level are given in this report are chiefly in this lowland region, which includes San Bernardino Valley, the foothill belt between San Bernardino Valley and Los Angeles, the coastal plain west and south of Los Angeles, and San Jacinto Valley and adjacent areas. (See Pl. I.) A few records are also given for wells in San Diego County (pp. 126-151).

The prosperity of this important region is very largely dependent upon its ground-water resources. Most of the water supplies, whether used for domestic purposes or irrigation, are obtained wholly or in part from ground water. In $1905 \mathrm{Mendenhall}^{2}$ estimated that twothirds of the land at that time under irrigation in this region obtained its water from subterranean sources during the protracted period of low run-off then prevailing. Since that time much more land has been brought under irrigation, and the proportion of land supplied with ground water has probably been increased.

In 1900 the United States Geological Survey began a series of studies of the occurrence, amount, distribution, and use of the ground water in the region, and published reports on the ground-water resources of San Bernardino Valley, ${ }^{3}$ the foothill belt, ${ }^{4}$ and the coastal

1 Mendenhall, W. C., Development of underground watersin the western coastal-plain region of southern California: U. S. Geol. Survey Water-Supply Paper 139, pp. 9-10, 1905.

2 Mendenhall, W. C., Proceedings of second conference of engineers of the Reclamation Service with accompanying papers: U. S. Geol. Survey Water-Supply Paper 146, p. 119, 1905.

3 Mendenhall, W. C., The hydrology of San Bernardino Valley, Calif.: U. S. Geol. Survey Water-Supply Paper 142, 1905.

- Mendenhall, W. C., Ground waters and irrigation enterprises in the foothill belt, southern California: U.S. Geol. Survey Water-Supply Paper 219, 1908. 
plain.5 A report on San Jacinto Valley and adjacent areas has recently been published. ${ }^{6}$ For such studies, records of the fluctuations of the water table extending over long periods are very valuable, because they show the extent of the depletion of the subterranean supply during times of light precipitation and heavy pumping and the extent of replenishment of this supply during the times of relatively heavy precipitation.

When the work was begun it was found that records of water-level fluctuations were available for only a few widely separated wells. Typical wells, properly distributed over the region under investigation, were therefore selected for observation, and measurements of the depths to the water level in these wells were made from time to time. In recent years additional wells have been selected and at least two measurements are made every year in each of the observation wells-one measurement in the spring, when the water level is generally highest, and one in the fall, when it is generally lowest. The Gage Canal Co. has furnished a record of a large number of measurements of a well known as the Williams well, near San Bernardino (see p. 121 and Pl. II), and Mr. J. B. Neff has furnished a record of measurements of his well near Anaheim (see well No. 41, p. 44, and Pl. IV).

Most of the data collected prior to 1912 have already been published ${ }^{7}$ in water-supply papers, but, for the convenience of those who wish to use the records, all the data are included in this report.

\section{CAUSES OF FLUCTUATIONS OF WATER TABLE.}

The supply of ground water in the valley of southern California is derived from the following sources:

1. The streams which rise in adjacent mountain regions and flow over the valley areas, where their water percolates into the underlying gravels. This is the source of most of the ground water, but, owing to the intensity of rainfall and the resulting rapid run-off in floods, much of the surface water escapes to the sea. Several methods of preventing this waste have been tried, the method most

${ }^{5}$ Mendenhall, W. C., Development of underground waters in the eastern coastal-plain region of southern Califormia: U.S. Geol. Survey Water-Supply Paper 137, 1905; Development of underground waters in the central coastal-plain region of southern California: U. S. Geol. Survey Water-Supply Paper 138, 1905; Development of underground waters in the western coastal-plain region of southern California: U. S. Geol. Survey Water-Supply Paper 139, 1905.

${ }^{6}$ Waring, G. A., Ground water in San Jacinto and Temecula basins, Calif.: U. S. Geol. Survey WaterSupply Paper 429, 1919.

? Clapp, W. B., The surface water supply of California, 1906, with a section on ground-water levels in southern California (Great Basin and Pacific Ocean drainages in California and Lower Colorado River drainage): U. S. Geol. Survey Water-Snpply Paper 213, pp. 189-205, 1907.

Clapp, W. B., and Martin, W. F., Surface water supply of the United States, 1907-8, Part XI, California, prepared under the direction of M. O. Leighton: U. S. Geal. Survey Water-Supply Paper 251, pp. 338-348, 1910.

McGlashan, H. D., and Stevens, G. C., Surface water supply of the United States, 1912, Part X, Pacific coast basins in California: U. S. Geol. Survey Water-Supply Paper 331, pp. 425-434, 1914. 
generally used being to increase the percolation area by spreading the flood waters over the débris cones where the streams enter the valley areas.

2. The rain which falls upon the valley areas. The amount of absorption from this source depends largely on the perviousness of the soil and underlying deposits.

3. The water applied in irrigation. During the irrigating season practically all surface water is conveyed through pipe lines or canals from the canyons to the points of application. After being applied to the land a considerable portion of the water sinks into the gravel and is added to the ground-water supply.

The supply of ground water is depleted by the following causes:

1. Pumping from wells for irrigation and domestic supply.

2. Discharge of springs and flowing wells.

3. Transpiration from vegetation.

4. Evaporation from sloughs and other low lands where the water table is near the surface.

A record of the fluctuations of the water table extending over a period of years will show the depletion and replenishment of the supply of ground water. Such a record, when studied in connection with records of precipitation and run-off, will show whether the supply, which has been depleted by superimposed draft due to increased use of ground water in addition to the natural depletion during dry years, is renewed during years of abundant rainfall. In a basin in which this does not take place either the replenishment must be increased by water spreading or other means, or else the withdrawals must be reduced by preventing waste or decreasing the pumpage. Otherwise the water table will be lowered to such a depth that it will no longer be profitable to pump the water.

\section{GENERAL CONDITIONS SHOWN BY THE RECORDS.}

To illustrate more plainly the favorable and unfavorable periods of replenishment and their effect on the ground-water level, graphs have been prepared showing precipitation, run-off, and fluctuation of the water table in the four principal areas-San Bernardino Valley, the foothill belt, the coastal plain, and San Jacinto Valley. The records of measurements during 1920 are given, but it has not been possible to bring the graphs up to date.

\section{SAN BERNARDINO VALLEY.}

San Bernardino Valley lies near the eastern end of the valley of southern California and consists of the lowlands in San Bernardino County, in the Redlands and San Bernardino quadrangles. (See Pl. I.) The hydrology of this region has been treated in WaterSupply Papers 60, 61, and 142. For this area there are several 
fairly long records of water-level fluctuation, which are of interest in a study of ground-water conditions.

The principal source of ground-water replenishment is Santa Ang River and its tributaries. The Geological Survey has measured the flow of Santa Ana River near the mouth of its canyon since 1896. (See Pl. I and table below.) The longest record of precipitation in the valley is that at the city of San Bernardino, kept by the United States Weather Bureau since 1870. (See Pl. I.) The Gage Canal Co. has kept a record of the fluctuation of the water level in the Williams well, about $4 \frac{1}{2}$ miles east of San Bernardino, since 1892. (See Pl. I and p. 121.)

Plate II shows the departure from the average annual precipitation at San Bernardino, the annual discharge of Santa Ana River at the mouth of its canyon, and the fluctuation of the water surface in the Williams well from observations made by the Gage Canal Co.

Observation wells Nos. 64 to 68 and 86 to 135 , inclusive, are located in San Bernardino Valley. (See Pl. I.)

Discharge, in acre-feet, of Santa Ana River at mouth of canyon, entrance to San Bernardino Valley.

\begin{tabular}{|c|c|c|c|c|c|c|c|c|c|c|c|c|c|}
\hline Year. & July. & Aug. & Sept. & Oct. & Nov. & Dec. & Jan. & Feb. & Mar. & Apr. & May. & June. & Total. \\
\hline & 753 . & 353 & 124 & 372 & & & 4.170 l & 10.282 & 7637 & 8.899 & 4.690 & 4.723 & $62,60 \mathrm{C}$ \\
\hline & 077 &, 303 & 968 & $\begin{array}{l}4,372 \\
3,347\end{array}$ & $\begin{array}{l}2,148 \\
2,678\end{array}$ & ' & 年, & $\begin{array}{r}10,284 \\
2,688\end{array}$ & & $\begin{array}{l}0,899 \\
2,333\end{array}$ & $\begin{array}{l}4,090 \\
3,727\end{array}$ & 2,840 & \\
\hline & 2,625 & 2,653 & 2,223 & 1,571 & 1,285 & 1,364 & 1,593 & 1,516 & 1,949 & 1,458 & 1,365 & 1,315 & 20,9 \\
\hline & 371 & 782 & 690 & 1,015 & 1,268 & 1,427 & 1,414 & 1,222 & 1,414 & 1,488 & 3,505 & 1,309 & 16,9 \\
\hline & 1,168 & 676 & 714 & 861 & 6,367 & 1,722 & 4,796 & 10,774 & 4,181 & 2,559 & 2,582 & 2,202 & $38,60 \mathrm{C}$ \\
\hline & 2,337 & 3,074 & 2,916 & 2,951 & 1,547 & 1,476 & 1,476 & 2,110 & 4,858 & 3,035 & 2,214 & 1,964 & $30,00 c$ \\
\hline & 1,599 & 1,537 & 1,428 & 2,398 & 1,428 & 1,353 & 2,029 & 2,666 & 9,100 & 20,945 & 5,657 & 3,808 & $53,90 C$ \\
\hline & 3,136 & 3,382 & 3,094 & 2,890 & 1,785 & 1,660 & 1,599 & 1,898 & 3,935 & 3,154 & 2,521 & 2,618 & 31,700 \\
\hline & 2,767 & 2,828 & 2,975 & 2,951 & 1,190 & 1,230 & 2,251 & 5,420 & 7,993 & 5,385 & 10,580 & 4,624 & $50,20 \mathrm{C}$ \\
\hline & 3,867 & 4,107 & 4,064 & 3,025 & 2,827 & 2,362 & 2,880 & 3,500 & 32,600 & 16,300 & 15,100 & 10,200 & 101,000 \\
\hline & & & 3,810 & 4,390 & 3,590 & 6,820 & 14,700 & 16,200 & 41,900 & 32,800 & 14,500 & 10,200 & $161,00 \mathrm{C}$ \\
\hline & 8,300 & 5,550 & 4,360 & 5,180 & 7,080 & 3,710 & 5,050 & 7,760 & 7,690 & 5,880 & 4,690 & 3,670 & 68,90 \\
\hline & 3,950 & 3,920 & 3,500 & 3,550 & 2,550 & 2,670 & 7,380 & 13,200 & 11,300 & 12,400 & 9,720 & 5,790 & 79,9 \\
\hline & 4,240 & 3,950 & 3,680 & 3,560 & 3,150 & 8,360 & $a 3,090$ & 6,220 & 6,330 & 6,250 & & 4,130 & \\
\hline & 4,000 & 3,840 & 3,870 & 3,780 & 2,800 & 2,730 & 7,870 & 10,900 & 27,900 & 12,700 & 7,990 & 6,190 & 94,60 \\
\hline & 5,470 & $\mathbf{3}, \mathbf{9 7 0}$ & 3,920 & 3,730 & 3,000 & 2,850 & 2,740 & 2,340 & 5,760 & 6,010 & & 3,750 & 48,9 \\
\hline & 3,730 & 3,700 & 3,520 & 3,370 & 2,330 & 2,250 & 2,100 & 2,480 & 3,340 & 3,650 & 3,590 & 3,420 & 37,5 \\
\hline & & 3,600 & 3,430 & 3,310 & 1,990 & 1,770 & 10,500 & 15,300 & 8,550 & 7,440 & 8,730 & 6,840 & 75,500 \\
\hline & & 4,370 & 3,800 & 3,630 & 2,850 & 3,030 & 4,700 & 15,900 & 11,100 & 14,400 & 18,900 & 14,000 & 102,000 \\
\hline & 9,840 & 6,150 & 4,840 & 4,390 & 4,020 & 3,880 & $\begin{array}{l}b 5 \\
5\end{array}, 500$ & $c 27,400$ & 47,200 & 23,700 & 15,600 & 10,900 & 163,000 \\
\hline & & 6,640 & 6,430 & 6,700 & 5,300 & 4,970 & 5,260 & 5,530 & 6,330 & 7,200 & 8,050 & 5,050 & $76,10 \subset$ \\
\hline & & & & & & & & & & & & & \\
\hline
\end{tabular}

FOOTHILL BELT.

The foothill belt of the valley of southern California is the area eastward from the Arroyo Seco, near Pasadena, along the base of the San Gabriel Range, to the west rim of San Bernardino Valley. It includes the Cucamonga Plain and the San Gabriel Valley and the divide separating them. The Cucamonga Plain is the lowland west of San Bernardino Valley and above Santa Ana Canyon, where the river breaks through the Santa Ana Mountains. San Gabriel Valley is the area drained by San Gabriel River and its tributaries above 


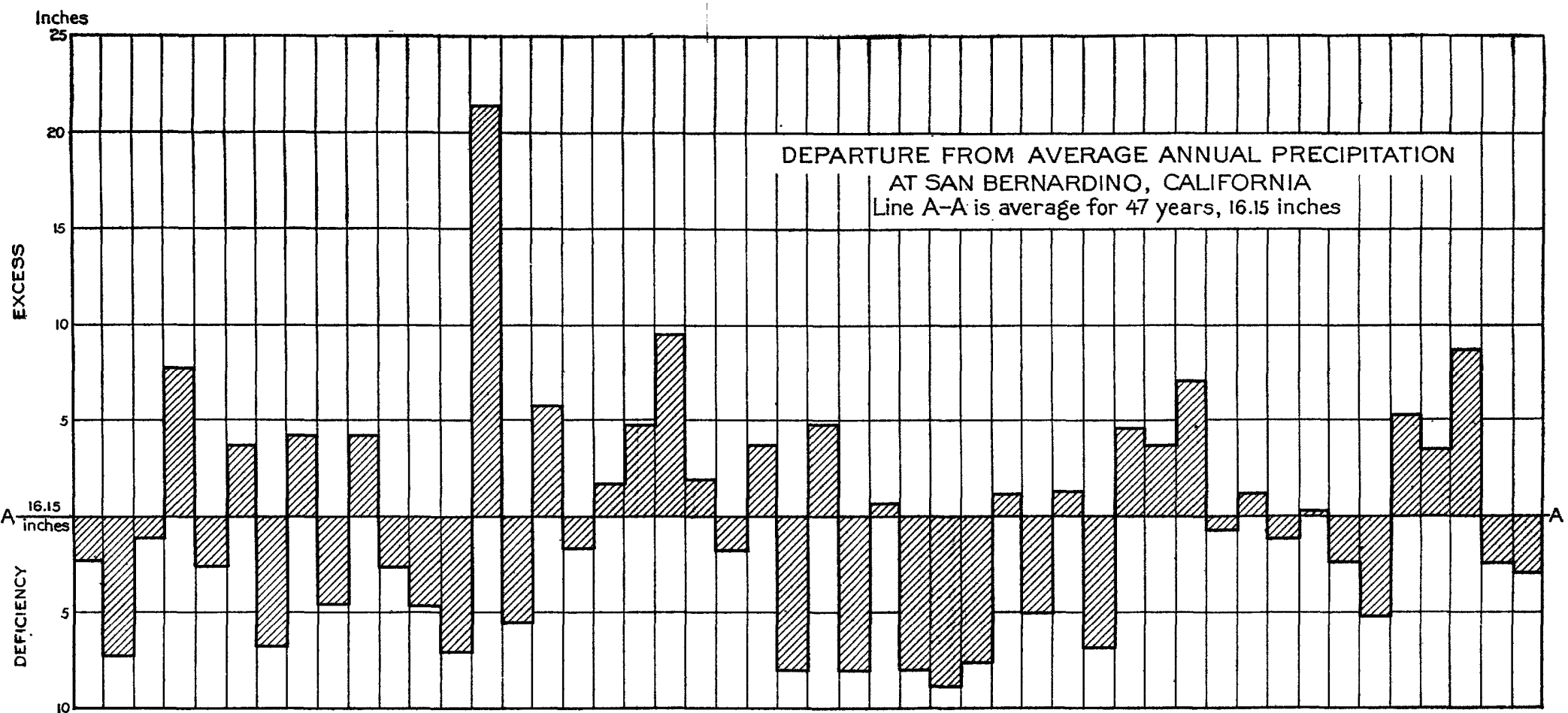

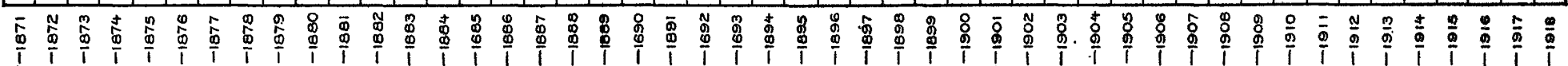

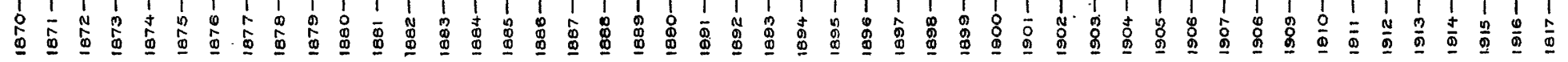

DISCHARGE OF SANTA ANA RIVER AT ENTRANCE TO SAN BERNARDINO VALLEY FROM 1896 TO 1917

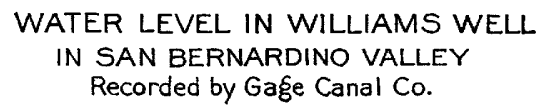

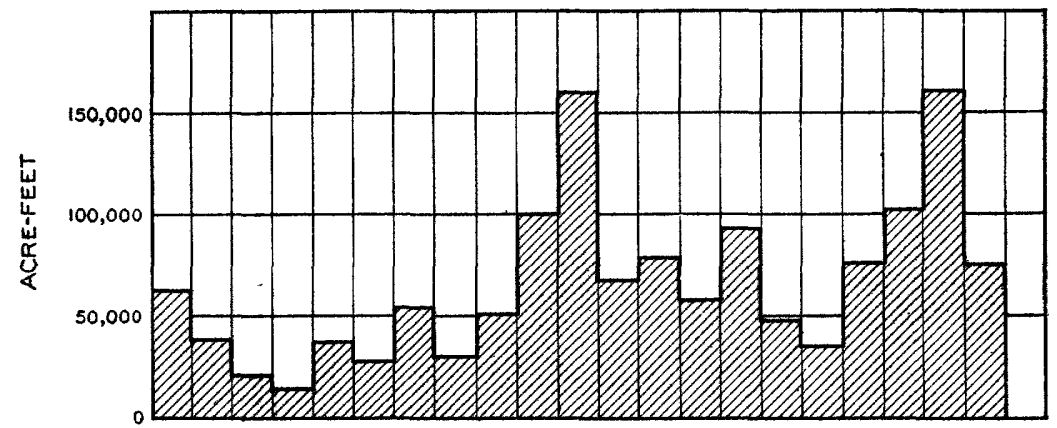

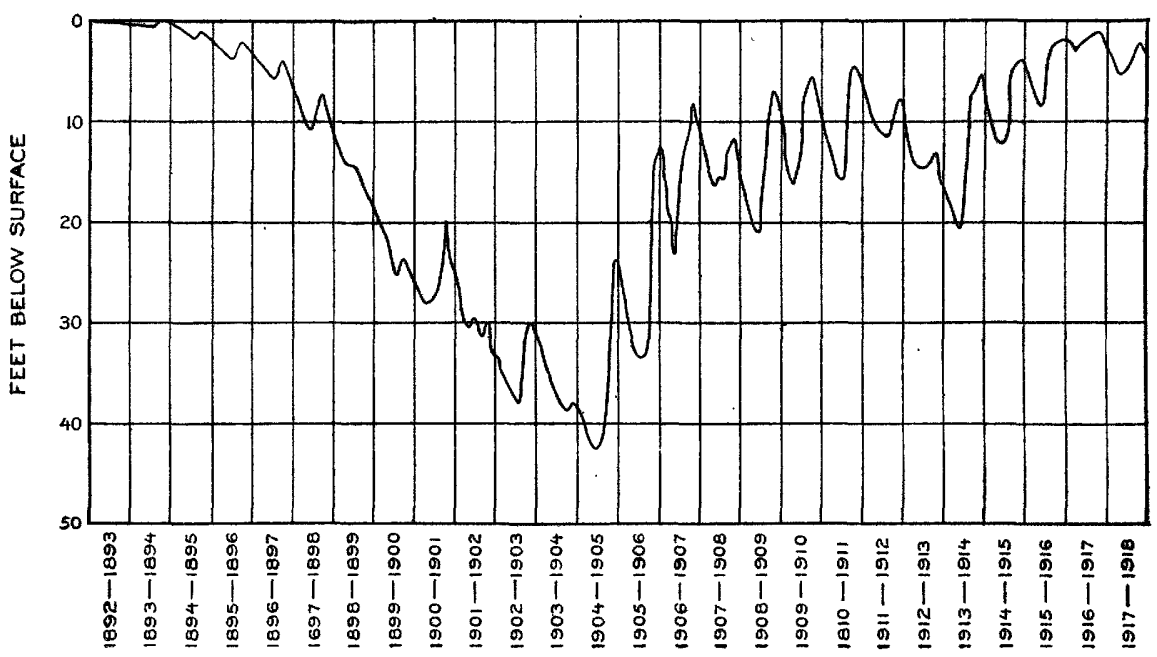





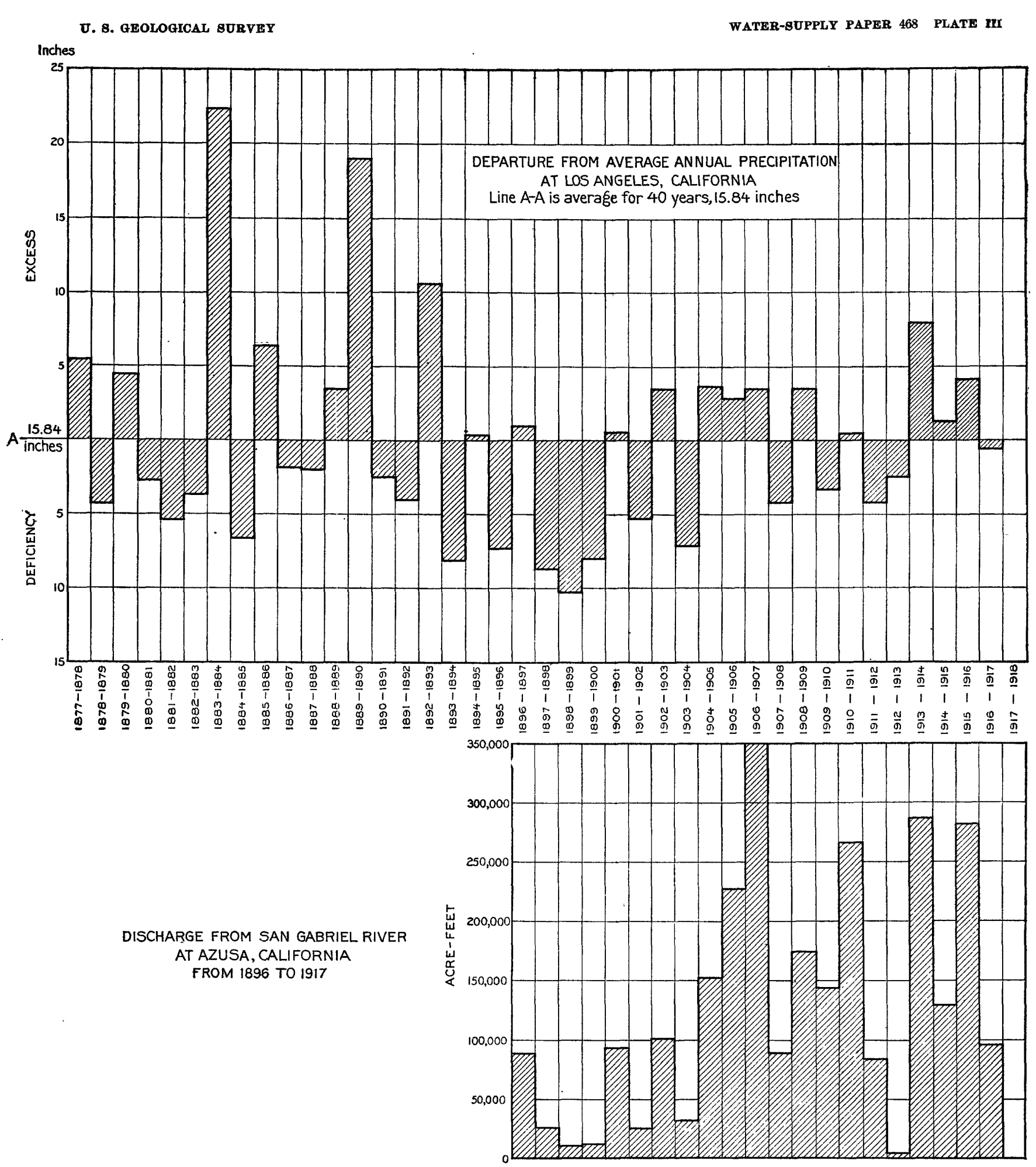




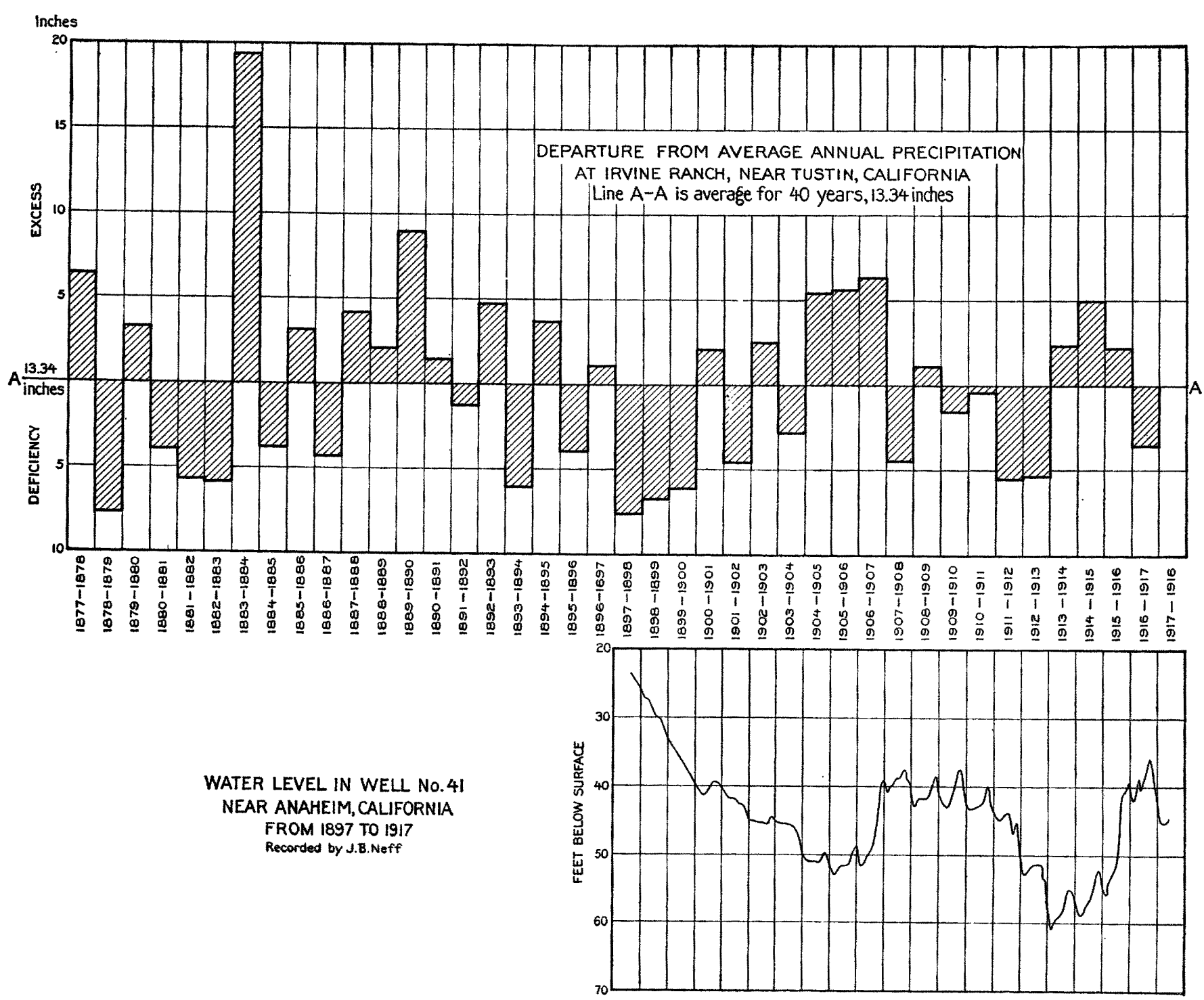

GRAPH Showing Fluctuation OF WATER LEVEL IN WELl No. 41 (NEFF WELI), IN THE COASTAL PLAIN OF SOUTHERN CALIFORNIA, TOGETHER WITH PRECIPITATION NEAR TUSTIN 
$\cdot$

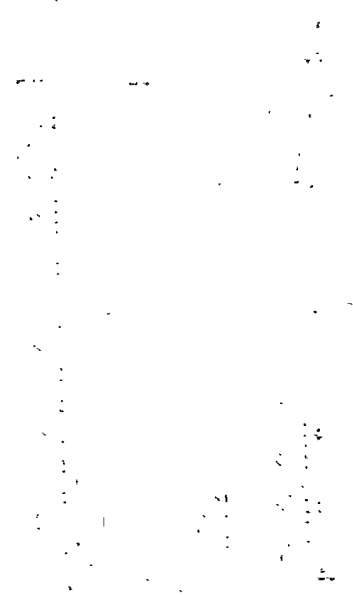

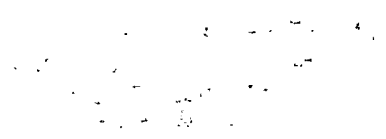

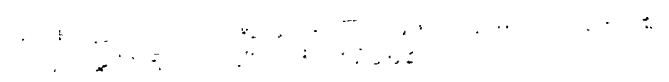


Paso de Bartolo except Arroyo Seco. The foothill belt is shown on the maps of the Cucamonga, Pomona, and Pasadena quadrangles. (See Pl. I.)

The principal source of ground water is the upper San Gabriel drainage basin. Important secondary sources are San Antonio, San Dimas, and other streams draining southwest from the San Gabriel Mountains. The United States Geological Survey has maintained a gaging station at the mouth of San Gabriel River Canyon since 1896. (See Pl. I.) The resulting discharge data, given in the table below, and the record of precipitation for Los Angeles, which has been kept since 1877, show the favorable and unfavorable years for augmenting subterranean storage. Hence, a comparison of these two records with the fluctuation of the water level in well No. 42 (p. 47), at Baldwin Park, is of interest. (See PI. III.)

Observation wolls Nos. 23 to 33 and 42 to 63a. inclusive are located in the foothill belt. (See Pl. I.)

Discharge, in acre-feet, of San Gabriel River near Azusa, Calif.

\begin{tabular}{|c|c|c|c|c|c|c|c|c|c|c|c|c|c|}
\hline Year. & ly. & ug. & Sept. & Det. & Nov. & Dec. & Jan. & Feb. & Mar. & Apr. & May. & June. & Total. \\
\hline $\begin{array}{l}7 . . \\
8 . \\
9 . \\
900 \\
1 . . \\
2 . . \\
3 . . \\
4 . . \\
6 . . \\
78 . \\
9 . . \\
0 . . \\
1 . . \\
2 . \\
4 . \\
5 . \\
6\end{array}$ & $\begin{array}{r}738 \\
2,343 \\
672 \\
221 \\
369 \\
1,845 \\
676 \\
2,644 \\
861 \\
5,103 \\
9,530 \\
8,360 \\
2,560 \\
5,040 \\
2,450 \\
5,230 \\
3,060 \\
1,690 \\
5,570 \\
7,010 \\
4,770 \\
3,140\end{array}$ & $\begin{array}{r}861 \\
1,613 \\
456 \\
295 \\
246 \\
1240 \\
430 \\
1,783 \\
793 \\
2,631 \\
4,480 \\
5,390 \\
2,210 \\
3,120 \\
1,710 \\
3,610 \\
1,960 \\
1,070 \\
3,630 \\
3,980 \\
3,570 \\
2,200\end{array}$ & $\begin{array}{r}774 \\
1,226 \\
467 \\
220 \\
238 \\
1,012 \\
298 \\
1,488 \\
643 \\
1,869 \\
2,840 \\
3,580 \\
1,820 \\
2,320 \\
1,370 \\
2,830 \\
1,550 \\
893 \\
2,730 \\
3,270 \\
2,810\end{array}$ & $\begin{array}{r}1,476 \\
5,564 \\
533 \\
683 \\
307 \\
1,476 \\
430 \\
1,476 \\
738 \\
1,771 \\
2,450 \\
4,090 \\
2,070 \\
2,310 \\
1,500 \\
3,140 \\
1,830 \\
910 \\
2,770 \\
2,770 \\
7,010\end{array}$ & $\begin{array}{r}1,131 \\
1,860 \\
580 \\
847 \\
11,068 \\
1,904 \\
1,131 \\
1,428 \\
762 \\
2,660 \\
2,400 \\
3,800 \\
1,960 \\
2,880 \\
1,870 \\
2,800 \\
1,730 \\
2,280 \\
2,440 \\
3,010 \\
4,130\end{array}$ & $\begin{array}{r}1,353 \\
1,875 \\
832 \\
1,247 \\
1,269 \\
1,660 \\
1,968 \\
1,476 \\
1,039 \\
2,466 \\
11,600 \\
3,600 \\
2,870 \\
20,900 \\
2,020 \\
2,870 \\
1,760 \\
2,170 \\
4,290 \\
3,580 \\
13,600\end{array}$ & $\begin{array}{r}3,617 \\
2,453 \\
1,414 \\
1,968 \\
10,391 \\
1,722 \\
9,100 \\
1,500 \\
2,251 \\
4,190 \\
58,400 \\
11,100 \\
25,500 \\
69,500 \\
37,200 \\
2,800 \\
2,910 \\
61,400 \\
7,380 \\
148,000 \\
9,280\end{array}$ & $\begin{array}{r}19,146 \\
2,241 \\
1,244 \\
1,111 \\
37,765 \\
2,055 \\
5,665 \\
2,744 \\
25,880 \\
3,780 \\
47,100 \\
15,000 \\
59,400 \\
11,500 \\
44,300 \\
2,230 \\
13,200 \\
121,000 \\
30,200 \\
39,400 \\
13,200\end{array}$ & $\begin{array}{r}28,623 \\
2,131 \\
1,623 \\
1,230 \\
13,589 \\
6,088 \\
15,802 \\
6,813 \\
75,140 \\
133,000 \\
116,000 \\
12,700 \\
26,300 \\
9,590 \\
122,000 \\
23,000 \\
10,200 \\
48,000 \\
21,500 \\
34,800 \\
13,600\end{array}$ & $\begin{array}{r}17,519 \\
1,950 \\
1,262 \\
1,012 \\
6,545 \\
3,928 \\
47,127 \\
5,337 \\
19,580 \\
34,400 \\
58,400 \\
9,280 \\
28,000 \\
8,270 \\
28,200 \\
18,000 \\
7,140 \\
21,400 \\
17,300 \\
19,900 \\
10,500\end{array}$ & \begin{tabular}{|r|}
8,851 \\
2,213 \\
842 \\
2,275 \\
7,440 \\
2,398 \\
13,343 \\
4,089 \\
17,090 \\
21,000 \\
21,500 \\
7,190 \\
15,200 \\
5,050 \\
16,600 \\
10,900 \\
4,970 \\
16,900 \\
20,400 \\
10,400 \\
8,610
\end{tabular} & $\begin{array}{r}4,033 \\
1,159 \\
565 \\
893 \\
3,749 \\
1,190 \\
5,653 \\
1,517 \\
8,271 \\
15,600 \\
15,100 \\
4,190 \\
8,570 \\
3,560 \\
7,500 \\
4,990 \\
2,890 \\
9,580 \\
11,400 \\
5,830 \\
5,270\end{array}$ & \begin{tabular}{|c|c}
3 & 88,10 \\
9 & 26,60 \\
5 & 10,50 \\
3 & 12,00 \\
93 & 93,00 \\
26,50 \\
102,00 \\
32,30 \\
153,00 \\
228,00 \\
350,00 \\
88,30 \\
176,000 \\
144,00 \\
267
\end{tabular} \\
\hline
\end{tabular}

\section{Coastal plain.}

The coastal plain has an area of approximately 775 square miles. It consists of the lands between the Santa Monica Mountains and the San Joaquin Hills and extends from the Santa Ana Mountains and Puente Hills to the Pacific. The drainage consists of Santa Ana River below the lower Santa Ana Canyon, San Gabriel River below Paso de Bartolo, Los Angeles River, and Santiago Creek. The region is shown on the maps of the Santa Monioa, Redondo, Downey, Las Bolsas, Santa Ana, and Anaheim quadrangles. (See Pl. I.)

The principal sources of ground water in this area are the flood waters of the streams that traverse the area. Plate IV shows the 
fluctuation of the water level in well No. 41, based on a record kept by the owner, Mr. J. B. Neff (see p. 44), and the variation of the annual precipitation at the Irvine ranch, near Tustin. (See Pl. I.) No gaging stations are maintained within the area, but the run-off records of Santa Ana River and San Gabriel River (see Pl. I and pp. 8 ,9) are applicable in comparing the causes of replenishment and depletion of ground-water supply as shown by the fluctuations of the water table.

Observation wells Nos. 1 to $22 \mathrm{c}$ and 34 to 41 , inclusive, are in the Coastal Plain. (See Pl. I.)

\section{SAN JACINTO VALLEY.}

San Jacinto Valley is the lowland area in the San Jacinto River drainage basin above Railroad Canyon, which is a few miles southwest of Perris. The region is shown on the maps of the San Jacinto and Elsinore quadrangles. (See Pl. I.)

The replenishment of ground water in this valley is largely by percolation from San Jacinto River during periods of high water, but, owing to the low permeability of the soils, the percolation is slow.

That there is an overdraft in some portions of the valley is indicated by figure 1, which shows the fluctuation at well No. 72 (see p. 75), and the departure from the average annual precipitation at San Jacinto. (See Pl. I.) It will be noted that in spite of favorable precipitation in the past four years the water table has been constantly lowered.

Observation wells Nos. 69 to 85a, inclusive, are in San Jacinto Valley. (See Pl. I.)

\section{EXPLANATION OF RECORDS.}

In 1900 Lippincott made measurements of the depth to the water level in approximately 900 wells in San Bernardino Valley. ${ }^{8}$ In 1904 Mendenhall measured the same wells. ${ }^{9}$ A large number of these wells have never since been measured by the United States Geological Survey and are not considered herein. At a few wells, however, measurements have been made at irregular intervals, and these measurements are included in this report. In 1913 the wells still in existence and a few companion wells were given new numbers (Nos. 86 to 135, inclusive), and are designated by these new numbers in the following tables. Data collected prior to 1913 from the wells which had been destroyed or were inaccessible in 1913 are published in a separate table (p. 120) under the numbers by which they are designated in Water-Supply Paper 142.

\footnotetext{
${ }^{8}$ Lippincott, J. B., Development and application of water near San Bernardino, Colton, and Riverside, Calif., Part II: U. S. Geol. Survey Water-Supply Paper 60, pp. 97-141, 1902.

${ }^{\circ}$ Mendenhall, W.C., The hydrology of San Bermardino Valley, Calif.: U. S. Gecl. Survey Water-Supply Paper 142, 124 pp. 12 pls., 1905.
} 
altitudes of bench marks of wells Nos. 86 to 135, inclusive, were determined by instrumental leveling and are believed to be accurate. For wells Nos. 86 to 135, inclusive, the bench marks described were not located until 1914, and all measurements prior to this date were made from the surface of the ground. Most of the wells have been described in earlier water-supply papers, and references to these papers are given under these wells.

In order to perpetuate the series, companion wells are being chosen, wherever possible, for wells in bad repair.

Observations of the pressure of a few flowing wells in San Bernardino Valley have also been started, and the data thus far obtained are given on pages $117-119$.

\section{THE RECORDS.}

\section{VALLEY OF SOUTHERN CALIFORNIA.}

Records of water levels in the valley of southern California.

1. Richard Kidøon, corner Forty-ninth and Main atreets, Los Angeles, Redondo quadrangle.

[Bored well, 52 feet deep, 7 inches in diameter; sunk about 1874; elevation of surface, about 165 feet above sea level; method of lift, wind; use, domestic. Water contains 840 parts per million of dissolved solids, Bench mark from which measurements were made is not known. Well No. 848, Water-Supply Paper 139, p. 94.]

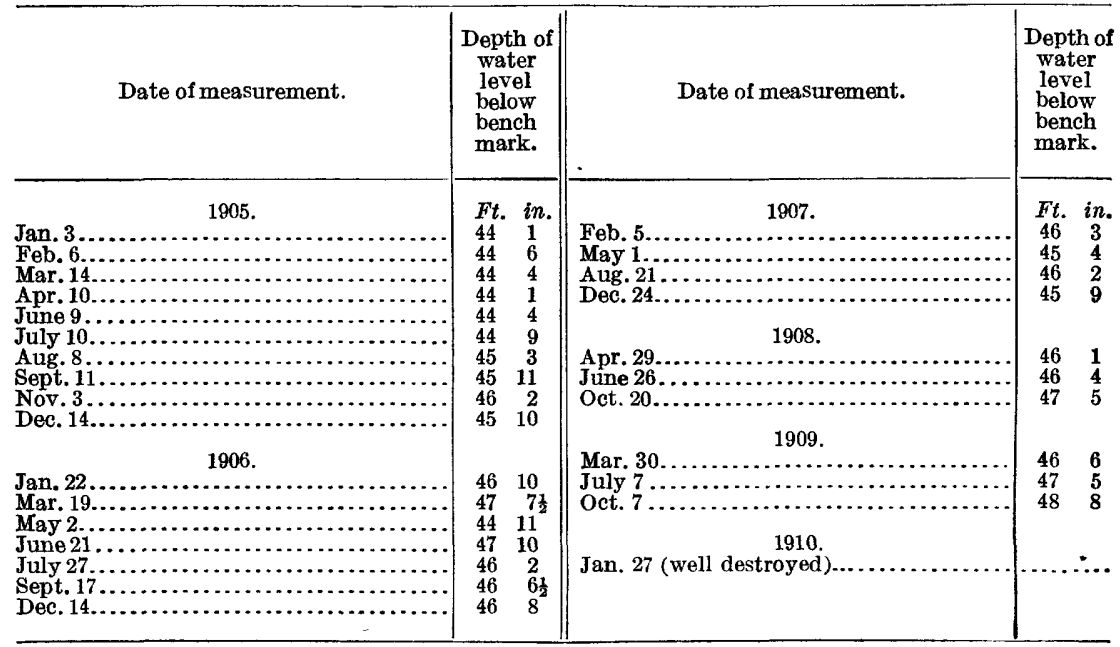




\section{Records of water levels in the valley of southern California-Continued.}

2. Chinese gardeners, half a mile southwest of Slauson, Redondo quadrangle.

[Bored well, 146 feet deep; sunk 1896; altitude of surface, about 145 feet above sea level; method of lift, wind; use, domestic and stock. Water contains 470 parts per million of dissolved solids. Bench mark from which measurements were made is not known. Well No. 800, Water-Supply Paper 139, p. 92.]

\begin{tabular}{|c|c|c|c|}
\hline Date of measurement. & $\begin{array}{l}\text { Depth of } \\
\text { water } \\
\text { level } \\
\text { below } \\
\text { bench } \\
\text { mark. }\end{array}$ & Date of measurement. & $\begin{array}{l}\text { Depth of } \\
\text { water } \\
\text { level } \\
\text { below } \\
\text { bench } \\
\text { mark. }\end{array}$ \\
\hline 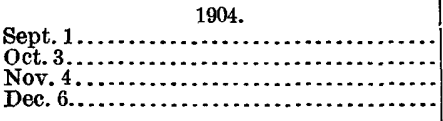 & $\begin{array}{ll}F t . & \text { in } \\
25 & 2 \frac{1}{2} \\
22 & 4 \frac{1}{2} \\
22 & 7 \frac{1}{2} \\
22 & 2\end{array}$ & 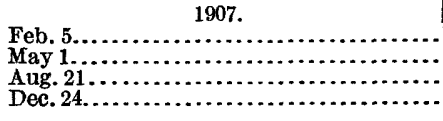 & $\begin{array}{lc}\text { Ft. } & \text { in. } \\
23 & 8 \\
22 & 1 \\
24 & 10 \\
23 & 12\end{array}$ \\
\hline 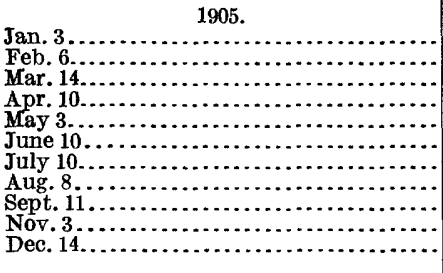 & \begin{tabular}{rr}
21 & 10 \\
21 & 9 \\
21 & $1 \frac{1}{2}$ \\
20 & 5 \\
20 & 5 \\
24 & 6 \\
23 & 0 \\
24 & 0 \\
24 & 7 \\
23 & 6 \\
23 & \multicolumn{1}{c}{$\frac{1}{2}$}
\end{tabular} & 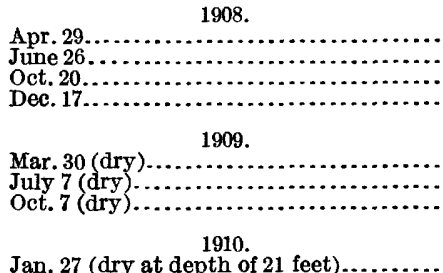 & $\begin{array}{rr}23 & 3 \\
25 & 1 \\
24 & 10 \\
24 & 8\end{array}$ \\
\hline 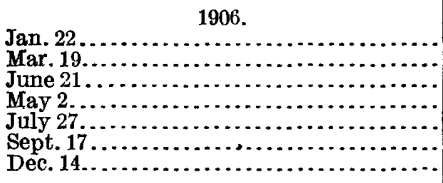 & $\begin{array}{ll}22 & 6 \\
22 & 1 \\
23 & 6 \frac{1}{2} \\
23 & 1 \\
24 & 3^{\frac{1}{2}} \\
25 & 3^{1} \\
23 & 8 \frac{1}{2}\end{array}$ & 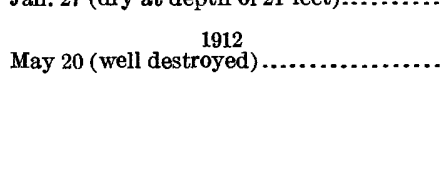 & \\
\hline
\end{tabular}

3. Eliza Connelly, Seventy-ninth and Budlong streets, Los Angeles, Redondo quadrangle.

[Bored well, 108 feet deep, 7 inches in diameter; aititude of surface about 140 feet; method of lift, wind; use, domestic and stock. Water contains 450 parts per million of dissolved solids. Bench mark: Top of casing, level with surface. Well No. 733, Water-Supply Paper 139, p. 90.]

\begin{tabular}{|c|c|c|c|}
\hline Date of measurement. & $\begin{array}{l}\text { Depth } \\
\text { of water } \\
\text { level } \\
\text { below } \\
\text { bench } \\
\text { mark. }\end{array}$ & Date of measurement. & $\begin{array}{l}\text { Depth } \\
\text { of water } \\
\text { level } \\
\text { below } \\
\text { bench } \\
\text { mark. }\end{array}$ \\
\hline 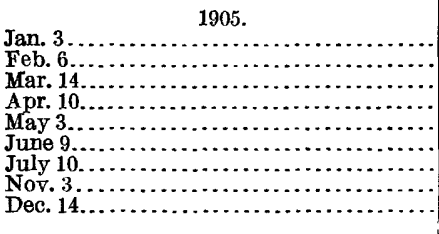 & $\begin{array}{lc}F t . & \text { in } \\
22 & 5 \\
22 & 6 \\
21 & 11 \\
21 & 6 \\
21 & 5 \\
22 & 7 \frac{1}{2} \\
23 & 6 \\
23 & 10 \\
23 & \frac{1}{2}\end{array}$ & 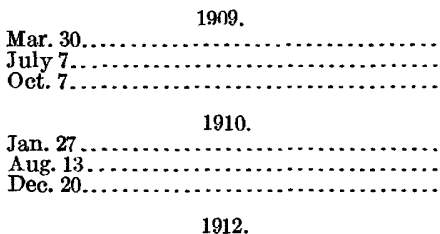 & $\begin{array}{lc}\text { Ft. } & \text { in. } \\
23 & 6 \\
25 & 11 \\
26 & 0 \\
& \\
24 & 7 \\
28 & 0 \\
27 & 0\end{array}$ \\
\hline 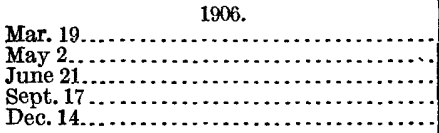 & $\begin{array}{ll}22 & 6 \\
22 & 7 \frac{1}{2} \\
23 & 9 \frac{1}{2} \\
24 & 4 \frac{1}{2} \\
23 & 7\end{array}$ & 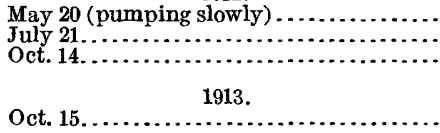 & $\begin{array}{rr}30 & 6 \\
33 & 1 \\
31 & 11 \\
& \\
& \\
37 & 2 \frac{1}{2}\end{array}$ \\
\hline 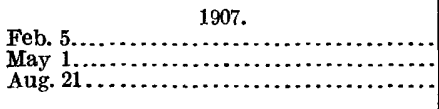 & $\begin{array}{lr}22 & 7 \\
22 & 7 \\
23 & 10\end{array}$ & 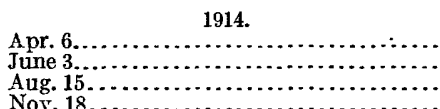 & $\begin{array}{lr}27 & 3 \frac{1}{2} \\
28 & 11 \\
29 & 2 \frac{1}{2} \\
29 & 3\end{array}$ \\
\hline 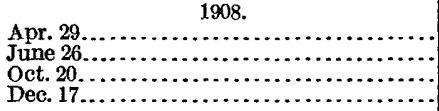 & $\begin{array}{ll}23 & 5 \\
24 & 6 \\
24 & 8 \\
24 & 4\end{array}$ & $\begin{array}{c}1915 . \\
\text { May } 28 \text { (well filled) ......... }\end{array}$ & ........... \\
\hline
\end{tabular}


Records of water levels in the valley of southern California-Continued.

4. Mrs. Bedell (former owners, Demmy Till and Mrs. Mary Vigus), Ninetieth Street and Vermont Avenue, Los Angeles, Redondo quadrangle.

[Bored well, 110 feet deep, 7 inches in diameter; altitude of surface, a bout 145 feet above sea level; method of lift, wind; use, domestic and stock. Water contains 680 parts per million of dissolved solids. Bench mark: Top of casing, 5 inches above surface. Well No. 713, Water-Supply Paper 139, p. 89. On July 21,1912 , found 2 feet of casing removed. Observations since that time have been corrected by adding 2 feet.]

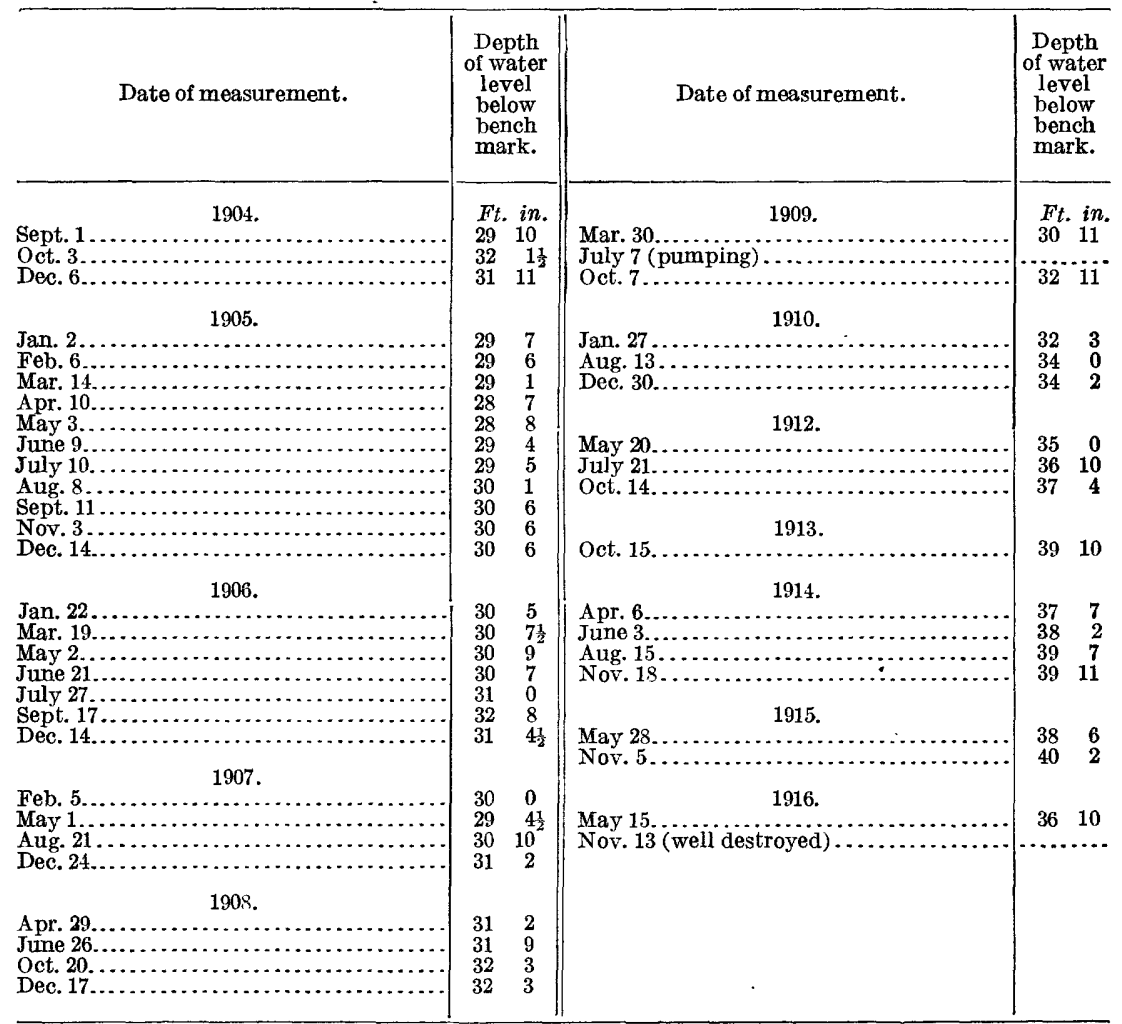

4a. Fred W. Lofland, 1131 West Ninety-second Street, Los Angeles, Redondo quadrangle.

[Well, 85 feet deep, 8-inch casing; method of lift, wind; use, domestic. Companion well for No. 4. Bench mark: Top of casing, 2 feet 7 inches above surface.]

\begin{tabular}{|c|c|c|c|}
\hline Date of measurement. & $\begin{array}{l}\text { Depth } \\
\text { of water } \\
\text { level } \\
\text { below } \\
\text { bench } \\
\text { mark. }\end{array}$ & Date of measurement. & $\begin{array}{l}\text { Depth } \\
\text { of water } \\
\text { level } \\
\text { below } \\
\text { bench } \\
\text { mark. }\end{array}$ \\
\hline 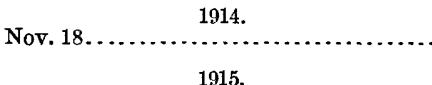 & $\begin{array}{l}F t . \\
54\end{array}$ & 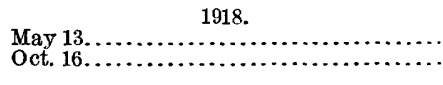 & $\begin{array}{lc}\text { Ft. } & \text { in } \\
54 & 10 \\
56 & 1\end{array}$ \\
\hline $\begin{array}{l}\text { May } 28 \ldots \ldots \ldots \ldots \ldots \ldots \ldots \ldots \ldots \ldots \ldots \ldots \ldots \ldots \ldots \ldots \ldots \ldots \ldots \ldots \ldots \\
\text { Nov. } 5, \ldots \ldots \ldots, \ldots \ldots \ldots \ldots\end{array}$ & $\begin{array}{ll}55 & 5 \\
55 & 8\end{array}$ & 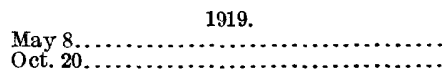 & $\begin{array}{lr}54 & 11 \\
56 & 5\end{array}$ \\
\hline $\begin{array}{l}\text { May } 15 \text { (pumping) } \ldots \ldots \ldots \ldots \ldots \ldots \ldots \ldots \ldots \ldots \\
\text { Nov. } 13 \ldots \ldots \ldots \ldots \ldots \ldots \ldots \ldots \ldots \ldots \ldots \ldots \ldots \ldots \ldots \ldots \ldots \ldots\end{array}$ & $\begin{array}{ll}78 & 0 \\
57 & 4\end{array}$ & 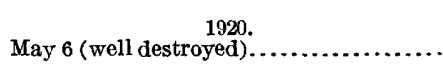 & $\ldots \ldots$ \\
\hline $\begin{array}{l}\text { May } 29 . \ldots \ldots \ldots \ldots \ldots \ldots \ldots \ldots \ldots \ldots \ldots \ldots \ldots \ldots \\
\text { Nov. } 19 \ldots \ldots \ldots \ldots \ldots \ldots \ldots \ldots \ldots \ldots \ldots\end{array}$ & $\begin{array}{ll}55 & 0 \\
56 & 8\end{array}$ & & \\
\hline
\end{tabular}


Records of water levels in the valley of southern California-Continued.

\section{J. B. Brockley, corner Vermont Avenue and Garfield Street, Los Angeles, Redondo quadrangle.}

[Bored well, 120 feet deep, 7 inches in diameter; sunk in 1884; altitude of surface, about 185 feet above sea level; method of lift, wind; use, domestic and stock. Water contains 440 parts per million of dissolved solids. Bench mark: Top of casing, 10 inches above surface. Well No. 700, Water-Supply Paper 139, p. 88. Hand pump installed since description given in Water-Supply Paper 139.]

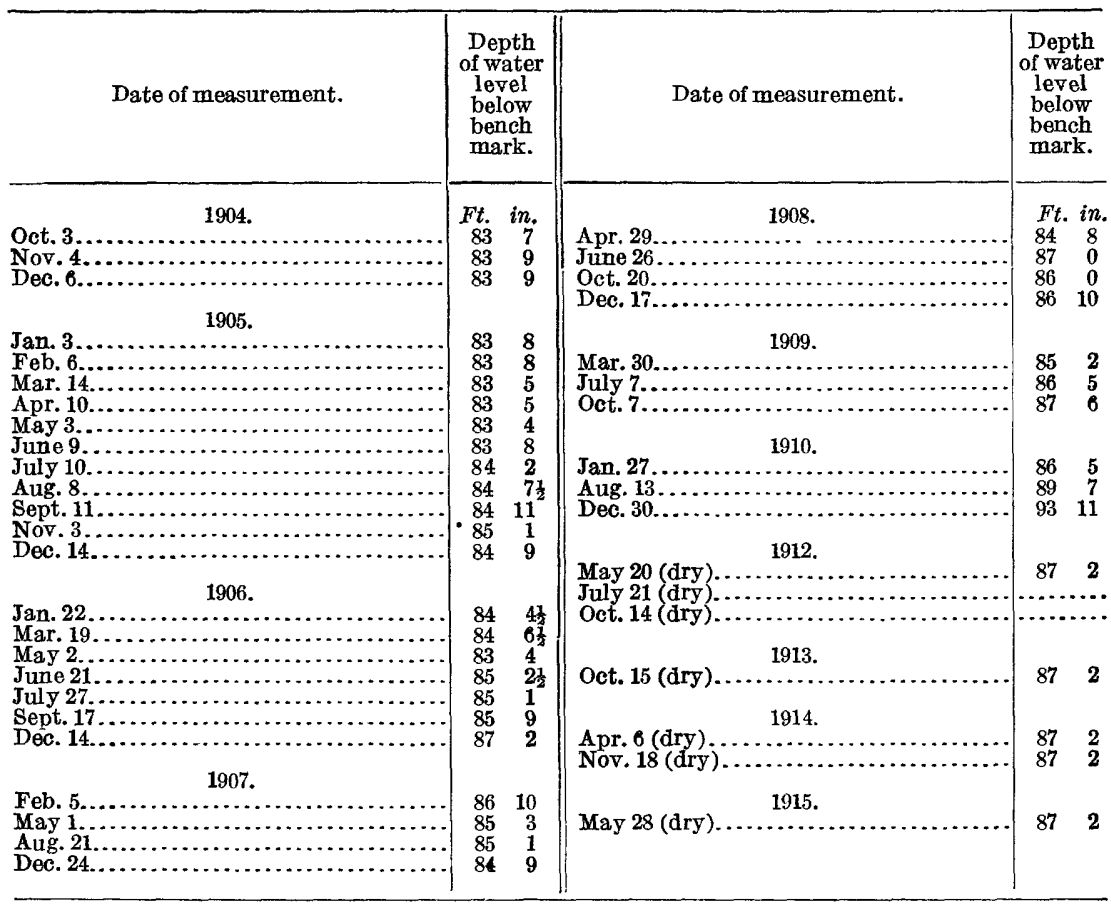

5a. Mrs. Bates, one-eighth mile west of Vermont Avenue on Garfield Street, Los Angeles, Redondo quadrangle.

[Well, 104 feet deep, 6-inch casing; method of lift, wind; use, domestic. Companion well for No. 5. Bench mark: Top of pipe bracket, 10 inches above surface.]

\begin{tabular}{|c|c|c|c|}
\hline Date of measurement. & $\begin{array}{c}\text { Depth } \\
\text { of water } \\
\text { level } \\
\text { below } \\
\text { bench } \\
\text { mark. }\end{array}$ & Date of measurement. & $\begin{array}{l}\text { Depth } \\
\text { of water } \\
\text { level } \\
\text { below } \\
\text { bench } \\
\text { mark. }\end{array}$ \\
\hline 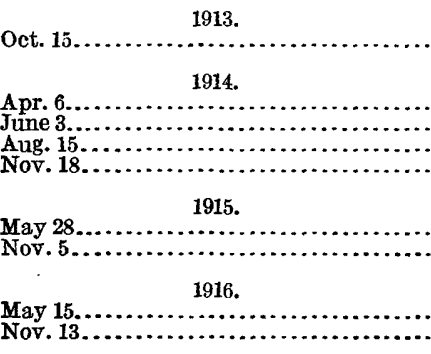 & $\begin{array}{rr}\text { Ft. } & \text { in. } \\
98 & 5 \\
& \\
96 & 10 \\
97 & 0 \\
98 & 8 \\
99 & 5 \\
& \\
97 & 8 \\
100 & 5 \\
& \\
98 & 6 \\
100 & 4\end{array}$ & 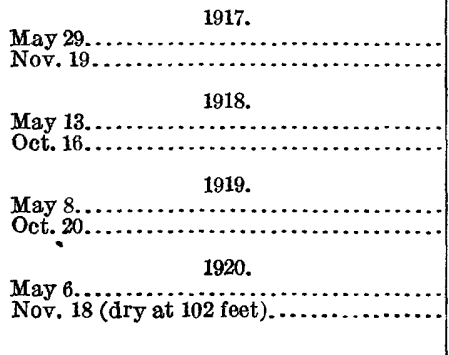 & $\begin{array}{rr}\text { Ft. } & \text { in. } \\
98 & 5 \\
102 & 6 \\
& \\
99 & 4 \\
100 & 10 \\
& \\
99 & 7 \\
102 & 1 \\
& \\
99 & 10 \\
9 & \end{array}$ \\
\hline
\end{tabular}




\section{Records of water levels in the valley of southern California-Continued.}

6. F. H. Carrel, $1 \frac{1}{2}$ miles southwest of Gardena, Redondo quadrangle.

[Bored well, 400 feet deep; sunk about 1900; altitude of surface, about 55 feet above sea level; water not used. Bench mark: Top of casing, level with surface. Well No. 1001, Water-Supply Paper 139, p. 99.]

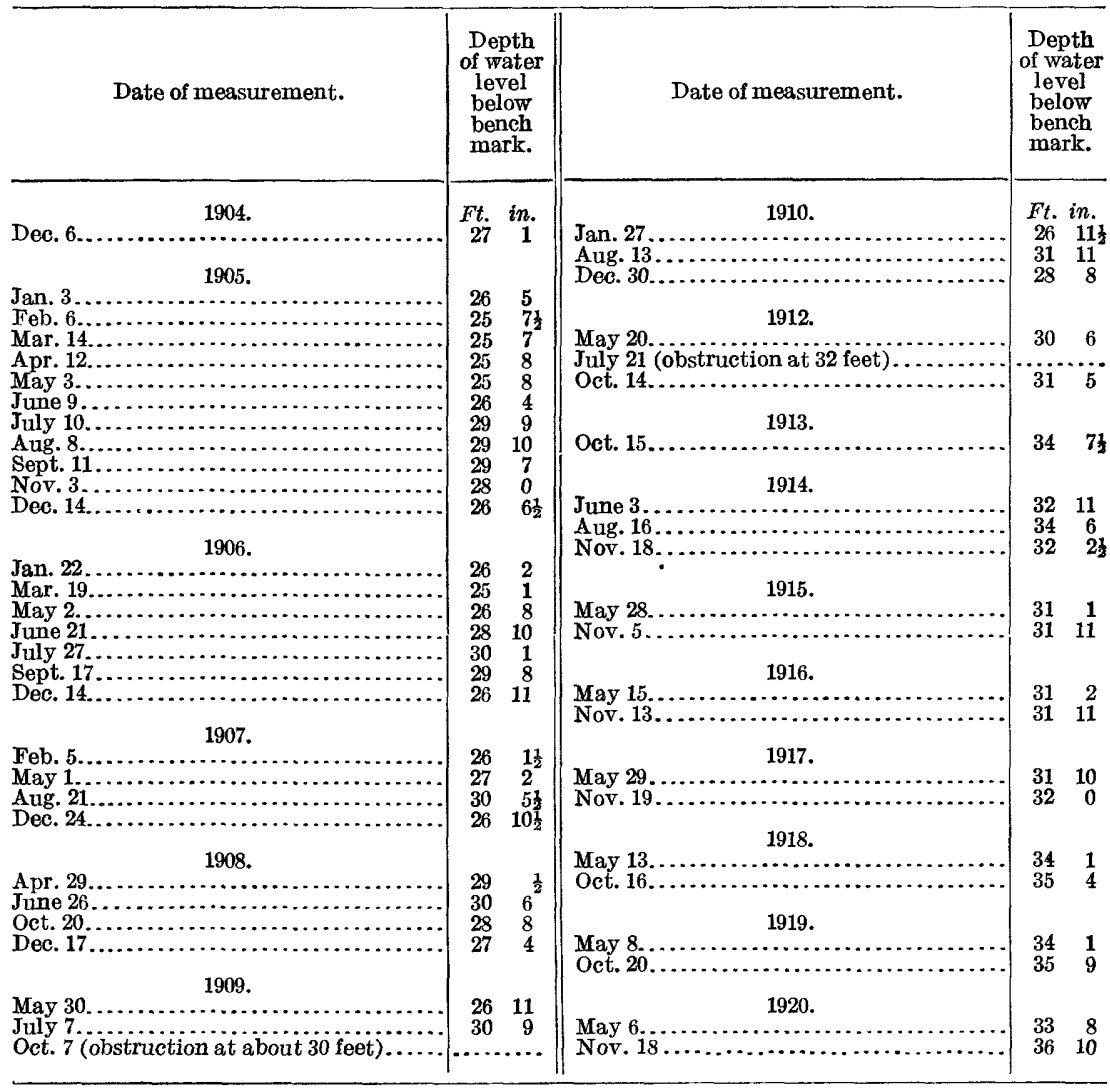

\section{A. B. Caldwell, one-fourth mile south of Moneta, Redondo quadrangle.}

[Bored well, 163 feet deep, 7 inches in diameter; sunk in 1897; altitude of surface, about 35 feet above sea level; method of lift, wind; use, domestic and stock. Water contains 360 parts per million of dissolved solids, Bench mark not known. Well No. 406, Water-Supply Paper 139, p. 76.]

\begin{tabular}{|c|c|c|c|}
\hline Date of measurement. & $\begin{array}{l}\text { Depth } \\
\text { of water } \\
\text { level } \\
\text { below } \\
\text { bench } \\
\text { mark. }\end{array}$ & Date of measurement. & $\begin{array}{c}\text { Depth } \\
\text { of water } \\
\text { level } \\
\text { below } \\
\text { bench } \\
\text { mark. }\end{array}$ \\
\hline 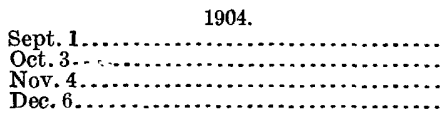 & $\begin{array}{lr}\text { Ft. } & \text { in } \\
41 & 11 \\
32 & 6 \\
38 & 11 \\
25 & 7\end{array}$ & 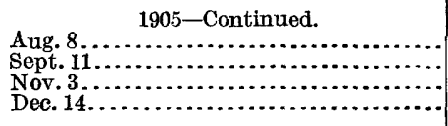 & $\begin{array}{ll}F t . & i \\
32 & 6 . \\
33 & 0 \\
28 & 4 \\
24 & 11\end{array}$ \\
\hline 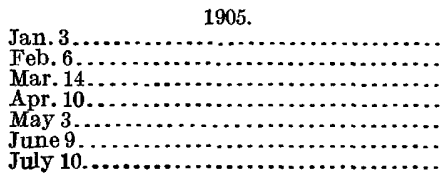 & $\begin{array}{rr}26 & 5 \\
41 & 9 \\
23 & 10 \\
48 & 2 \\
42 & 10 \\
32 & 2 \\
33 & 0\end{array}$ & 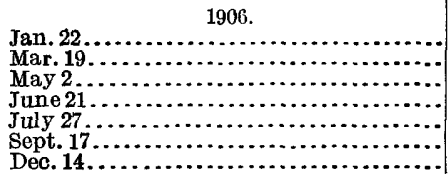 & $\begin{array}{cc}24 & 6 \\
23 & 8 \\
27 & 11 \\
32 & 3 \\
32 & 6 \frac{1}{2} \\
30 & 81 \\
25 & 0\end{array}$ \\
\hline
\end{tabular}


Records of water levels in the valley of southern California-Continued.

7. A. B. Caldwell-Continued.

\begin{tabular}{|c|c|c|c|}
\hline Date of measurement. & $\begin{array}{c}\text { Depth } \\
\text { of water } \\
\text { level } \\
\text { below } \\
\text { bench } \\
\text { mark. }\end{array}$ & Date of measurement. & $\begin{array}{c}\text { Depth } \\
\text { of water } \\
\text { level } \\
\text { below } \\
\text { bench } \\
\text { mark. }\end{array}$ \\
\hline 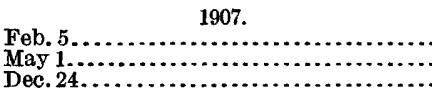 & $\begin{array}{lc}\text { Ft. } & \text { in. } \\
24 & 4 \frac{1}{2} \\
27 & 7 \\
24 & 117\end{array}$ & 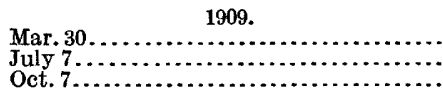 & $\begin{array}{lc}\text { Ft. } & \text { in. } \\
25 & 0 \\
33 & 6 \\
30 & 1\end{array}$ \\
\hline 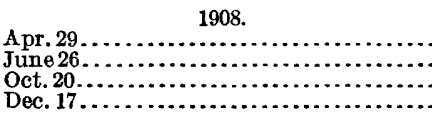 & $\begin{array}{ll}32 & 7 \\
33 & 6 \\
27 & 6 \\
25 & 7\end{array}$ & $\begin{array}{l}\text { Jan. } 27 \ldots 10 . \\
\text { Aug. } 13 \ldots \ldots \ldots \ldots \ldots \ldots \\
\text { Dec. } 30(\text { well inacessible }) \ldots \ldots \ldots \ldots \ldots\end{array}$ & $\begin{array}{rr}25 & 4 \\
35 & (?) \\
\cdots & \end{array}$ \\
\hline
\end{tabular}

8. C. C. Jorgensen (formerly owned by $\mathrm{H}$. J. Harris), half a mile north of Moneta, Redondo quadrangle.

[Bored well, 205 feet deep; sunk in 1902; altitude of surface, about 55 feet above sea level; method of lift, wind. Bench mark: Top of 1-inch cover over casing, a foot above surface. Well No. 295, Water-Supply Paper 139, p. 72.]

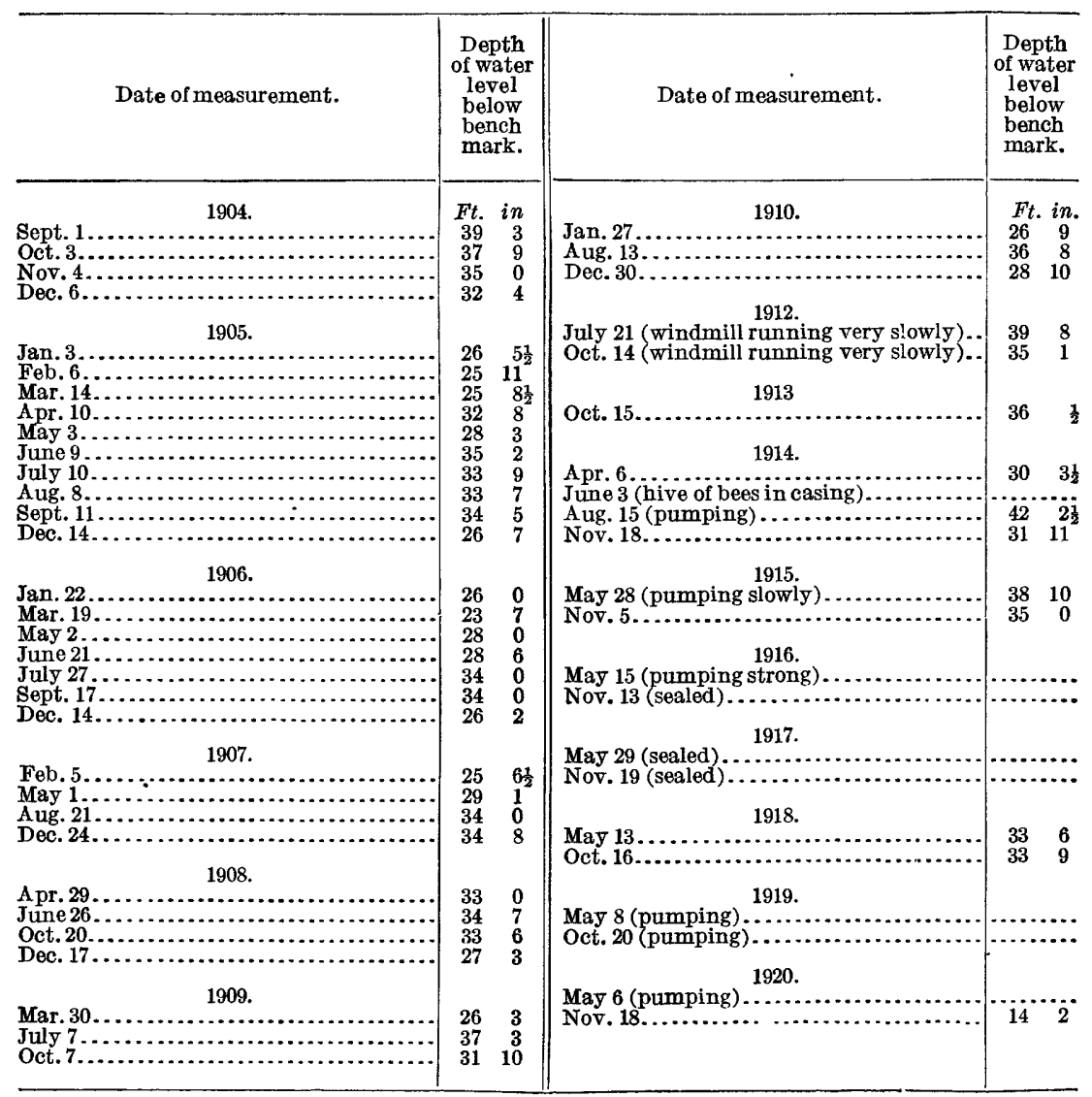




\section{Records of water levels in the valley of southern California-Continued.}

8a. Ben Long, five-eighths mile northwest of Moneta, Redondo quadrangle.

[Companion well for Nos. 8 and 9a; 185 feet deep, 8-inch casing; method of lift, wind; use, domestic. Bench mark: Top of casing, 2 feet above surface.]

\begin{tabular}{|c|c|c|c|}
\hline Date ofmeasurement. & $\begin{array}{c}\text { Depth } \\
\text { of water } \\
\text { level } \\
\text { below } \\
\text { bench } \\
\text { mark. }\end{array}$ & Date of measurement. & $\begin{array}{l}\text { Depth } \\
\text { of water } \\
\text { level } \\
\text { below } \\
\text { bench } \\
\text { mark. }\end{array}$ \\
\hline 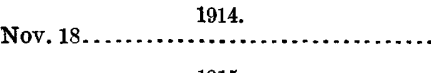 & $\begin{array}{cc}\text { Ft. } & \text { in. } \\
37 & 7\end{array}$ & 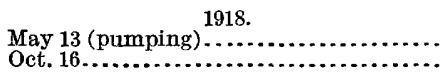 & 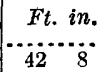 \\
\hline 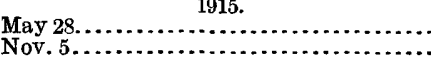 & $\begin{array}{cr}41 & 10 \\
37 & 6\end{array}$ & 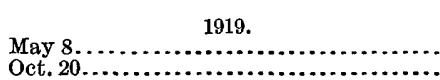 & $\begin{array}{l}43 \\
42\end{array}$ \\
\hline 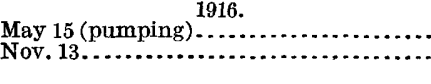 & $\begin{array}{ll}39 & 8 \\
36 & 5\end{array}$ & 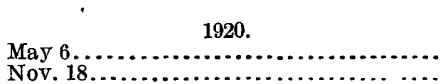 & $\begin{array}{l}43 \\
41\end{array}$ \\
\hline 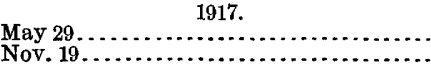 & $\begin{array}{ll}41 & 8 \\
38 & 2\end{array}$ & & \\
\hline
\end{tabular}

9. Ben Long (formerly owned by Stanley Bates), three-fourths mile northwest of Moneta, Redondo quadrangle.

LBored well, 10 inches in diameter; sunk in 1903; altitude of surface, about 62 feet above sea level. Water contains 1,040 parts per million of dissolved solids. Bench mark not known. Well No. 284, WaterSupply Paper 139, p. 71.]

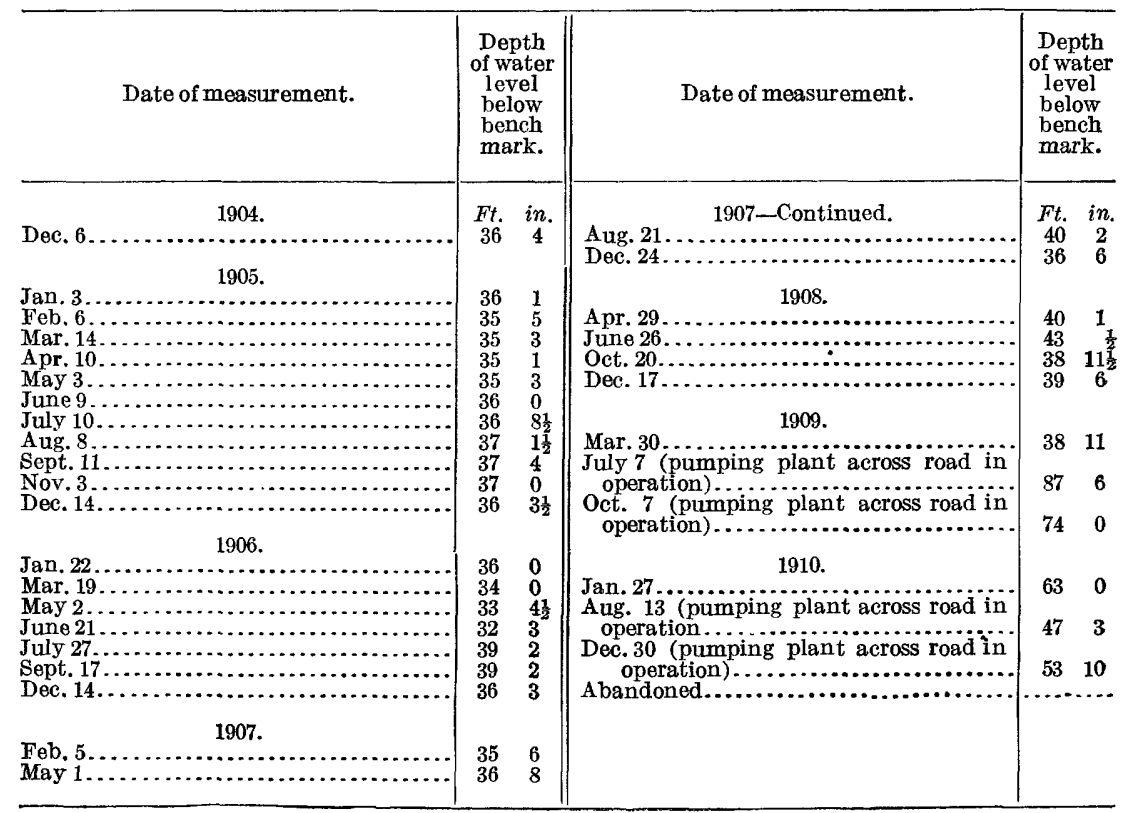


Records of water levels in the valley of southern California-Continued.

9a. W. G. Summers, five-eighths of a mile northwest of Moneta, Redondo quadrangle.

[Bored well, 171 feet deep, 7 inches in diameter; sunk in 1893; altitude of surface, about 60 feet above sea level; method of lift, wind; use, domestic. Water contains 600 parts per million of dissolved solids. Bench mark: Top of casing $1 \frac{1}{2}$ feet above surface. Well No. 285, Water-Supply Paper 139, p. 72 . Companion well for No. 9.]

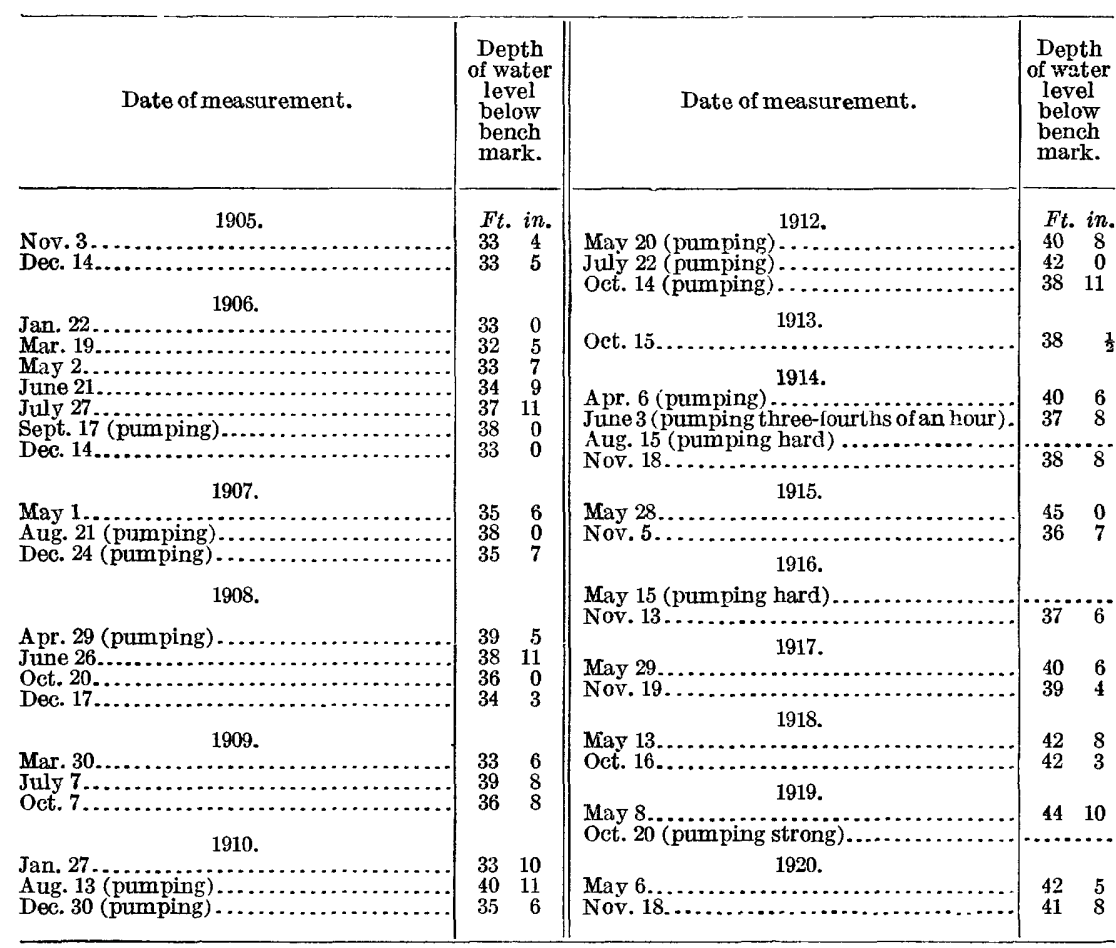

10. A. P. Johnson (formerly owned by Post \& Lockhart), 2 miles west of Howard Summit, Redondo quadrangle.

[Bored well, 200 feet deep, 7 inches in diameter; sunk in 1895; altitude of surface, about 62 feet above sea level; method of lift, wind; use, domestic. Water contains 430 parts per million of dissolved solids. Bench mank: Top of blocks resting over casing, 1 foot above surface. Well No. 255, Water-Supply Paper 139, p. 70.]

\begin{tabular}{|c|c|c|c|}
\hline Date of measurement. & $\begin{array}{l}\text { Depth } \\
\text { of water } \\
\text { level } \\
\text { below } \\
\text { bench } \\
\text { mark. }\end{array}$ & Date of measurement. & $\begin{array}{l}\text { Depth } \\
\text { of water } \\
\text { level } \\
\text { below } \\
\text { bench } \\
\text { mark. }\end{array}$ \\
\hline 1904. & Ft. in. & 1906-Continued. & Ft. in. \\
\hline Dec. 6 .................... & $35 \quad 7 \frac{1}{2}$ & June $21 \ldots \ldots \ldots \ldots$ & $38 \quad 2$ \\
\hline $\operatorname{Jan} .3 \ldots \ldots \ldots$ & & July $27 .$. & $\begin{array}{ll}37 & 10 \\
37 & 108\end{array}$ \\
\hline Feb. $6 \ldots \ldots$ & 38 & Dec. $14 \ldots$ & $37 \quad 1 \frac{1}{2}$ \\
\hline Mar. $14 \ldots . . .$. & 374 & & \\
\hline 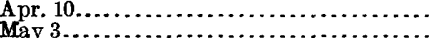 & $\begin{array}{ll}35 & 8 \\
35 & 9\end{array}$ & 1907. & \\
\hline July $10, \ldots \ldots \ldots$ & $\begin{array}{ll}50 \\
38 & 6\end{array}$ & May $1, \ldots \ldots \ldots \ldots \ldots \ldots \ldots \ldots$ & $\begin{array}{rr}38 & 4 \frac{1}{2} \\
30 & 10 \frac{1}{2}\end{array}$ \\
\hline Aug. $8 \ldots . .$. & 403 & Dec. 24 . & $30 \quad 9$ \\
\hline $\begin{array}{l}\text { Sept. } 11, \ldots \\
\text { Dec. } 14 \ldots \ldots\end{array}$ & $\begin{array}{ll}47 & 4 \\
39 & 3\end{array}$ & 1908 & \\
\hline 1906. & & Apr. 29 (pumping)....... & \\
\hline $\begin{array}{l}\text { Jan. } 22 \ldots \ldots \ldots \\
\text { Mar. } 19 . \ldots \ldots \ldots\end{array}$ & $\begin{array}{l}36 \\
34\end{array}$ & June $26 \ldots \ldots \ldots$ & .37 \\
\hline May $2 . . . . . . . .$. & $\begin{array}{ll}04 & 5 \\
33 & 4 \frac{1}{2}\end{array}$ & Dec. $17 . . . . . . . . . . . . . .$. & 36 \\
\hline
\end{tabular}


Records of water levels in the valley of southern California-Continued.

10. A. P. Johnson-Continued.

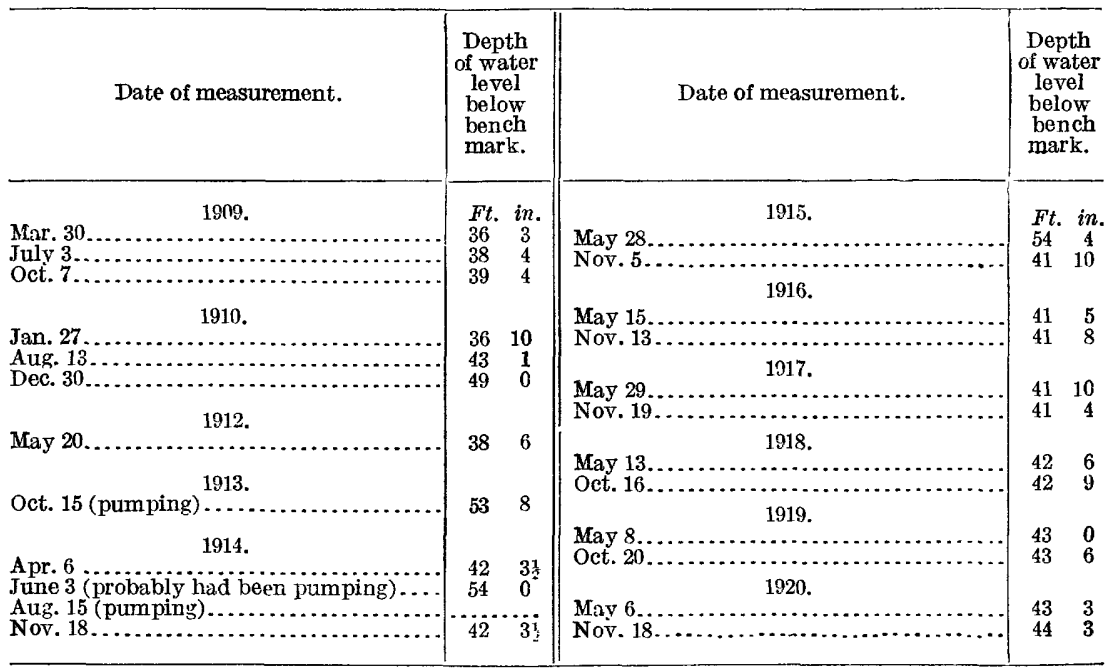

\section{E. L. Doheny (formerly owned by William Bayley), 10 Chester Place, Los Angeles, Santa Monics} quadrangle.

[Bored well, 88 feet deep, 7 inches in diameter; altitude of surface, about 205 feet above sea level; water not used. Bench mark: Top of casing, 1.0 foot above surface. Well No. 962, Water-Supply Paper 139, p. 59.]

\begin{tabular}{|c|c|c|c|}
\hline Date of measurement. & $\begin{array}{l}\text { Depth } \\
\text { of water } \\
\text { level } \\
\text { below } \\
\text { bench } \\
\text { mark. }\end{array}$ & Date of measurement. & $\begin{array}{l}\text { Depth } \\
\text { of water } \\
\text { level } \\
\text { below } \\
\text { bench } \\
\text { mark. }\end{array}$ \\
\hline 1904. & Ft. In. & 1909. & Ft. in. \\
\hline 1905. & & $\begin{array}{l}\text { July } 8, \ldots \ldots \ldots \ldots \\
\text { Oct. } 8, \ldots \ldots \ldots \ldots\end{array}$ & $\begin{array}{ll}72 & 2 \\
72 & 7\end{array}$ \\
\hline Jan. $6 .$. & & 1910. & \\
\hline & 695 & Jan. $28 \ldots . .$. & 7210 \\
\hline ............... & 69 & Aug. $12 \ldots \ldots \ldots \ldots \ldots$ & 728 \\
\hline$\cdots$ & $\begin{array}{l}69 \\
69\end{array}$ & Dec. $31 \ldots \ldots \ldots \ldots$ & 74 \\
\hline & 698 & May $21 \ldots .$. & 77 \\
\hline ....... & $69 \quad 10$ & Oet. $12 \ldots$ & 83 \\
\hline $9 \ldots \ldots \ldots \ldots \ldots$ & $\begin{array}{ll}70 & 0 \\
70 & 11\end{array}$ & Oct 24 & 87 \\
\hline & 70 & 1914. & \\
\hline Dec. $15 . \ldots .$. & 70 & June $3 \ldots \ldots \ldots \ldots$ & 82 \\
\hline 1906. & & Nov. 18 (dry, well filled in)..... & $\begin{array}{l}82 \\
82\end{array}$ \\
\hline & $\begin{array}{ll}70 & 0 \\
70 & 4\end{array}$ & 1915 & \\
\hline & $70 \quad 6 \frac{1}{2}$ & May $29 . \ldots \ldots \ldots \ldots \ldots$ & 82 \\
\hline & $\begin{array}{l}70 \\
70\end{array}$ & Nov, 5 (wet sand) ...... & \\
\hline $18 . .$. & 70 & May $15 \ldots . . . .$. & 81 \\
\hline Dec. $15 \ldots . .$. & 71 & Nov. $13 . .$. & 81 \\
\hline Feb. 6...... & & May $29 \ldots$ & 79 \\
\hline May $2 \ldots . .$. & 70 & Nov, $19 \ldots$ & 81 \\
\hline g. $22 \ldots$ & 70 & May $13 . . . . . . .$. & \\
\hline Dec. $25 . .$. & & Oct. 16. & 80 \\
\hline 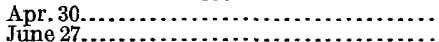 & $\begin{array}{rr}70 & 6 \\
70 & 10\end{array}$ & 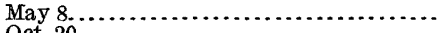 & $\begin{array}{l}79 \\
79\end{array}$ \\
\hline Oct. $21 . . . .$. & 71010 & 1920. & \\
\hline Dec. $18 . . . . . . . . .$. & 7111 & May $6 . . .$. & $\begin{array}{ll}78 & 11\end{array}$ \\
\hline
\end{tabular}


Records of water levels in the valley of southern California-Continued.

12. Tony Bright, northwest corner Jefferson Street and Vermont Avenue, Los Angeles, Santa Monica quadrangle.

[Bored well, 135 feet deep, 7 inches in diameter; sunk in 1894; altitude of surface, about 184 feet above sea level; method of lift, wind; use domestic. Water contains 640 parts per million of dissolved solids. Bench mark not known. Well No. 186, Water-Supply Paper 139, p. 29.]

\begin{tabular}{|c|c|c|c|}
\hline Date of measurement. & $\begin{array}{c}\text { Depth } \\
\text { of water } \\
\text { level } \\
\text { below } \\
\text { bench } \\
\text { mark. }\end{array}$ & Date of measurement. & $\begin{array}{l}\text { Depth } \\
\text { of water } \\
\text { level } \\
\text { below } \\
\text { bench } \\
\text { mark. }\end{array}$ \\
\hline 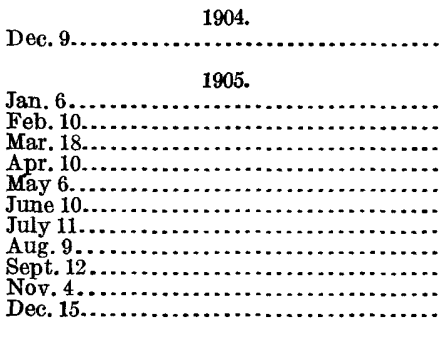 & $\begin{array}{cc}\text { Ft. } & \text { in. } \\
48 & 6 \\
& \\
48 & 8 \\
48 & 10 \\
48 & 8 \frac{1}{2} \\
48 & 4 \\
48 & 1 \\
48 & 6 \\
48 & 10 \frac{1}{2} \\
49 & 1 \frac{1}{2} \\
49 & 4 \frac{1}{2} \\
49 & 6 \\
49 & 8 \frac{1}{2}\end{array}$ & 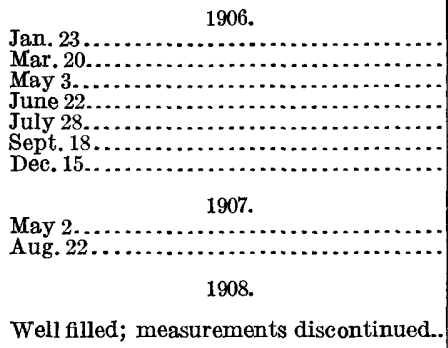 & $\begin{array}{cc}F t . & \text { in. } \\
49 & 8 \\
49 & 4 \\
49 & 4 \\
49 & 6 \frac{1}{2} \\
49 & 10 \\
50 & 1 \\
50 & 0 \\
& \\
& \\
49 & 3 \frac{1}{2} \\
49 & 8 \frac{1}{2}\end{array}$ \\
\hline
\end{tabular}

13. Mrs. Showers (formerly Mrs. Emelie Hertel), 1870 West Jefferson Street, Los Angeles, Santa Monica quadrangle.

[Bored well, 60 feet deep, 7 inches in diameter; stunk in 1897; altitude of surface, about 157 feet above sea level; method of lift, wind; use, domestic. Water contains 410 parts per million of dissolved solids Bench mark not known. Well No. 198, Water-Supply Paper 139, p. 29.]

\begin{tabular}{|c|c|c|c|}
\hline Date of measurement. & $\begin{array}{l}\text { Depth } \\
\text { of water } \\
\text { level } \\
\text { below } \\
\text { bench } \\
\text { mark. }\end{array}$ & Date of measurement. & $\begin{array}{l}\text { Depth } \\
\text { of water } \\
\text { level } \\
\text { below } \\
\text { bench } \\
\text { mark. }\end{array}$ \\
\hline 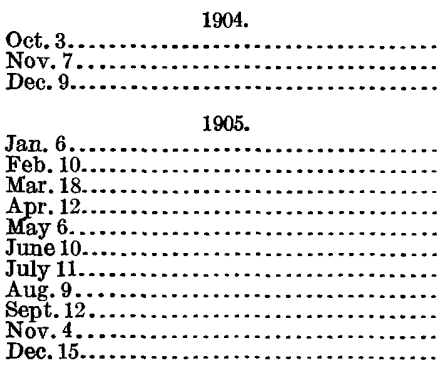 & $\begin{array}{rr}\text { Ft. } & \text { in. } \\
33 & 8 \\
33 & 9 \\
33 & 6 \\
& \\
33 & 6 \\
33 & 0 \\
32 & 2 \\
32 & 1 \\
32 & 9 \\
33 & 0 \\
33 & 9 \\
34 & 4 \\
34 & 7 \\
34 & 9 \\
34 & 3\end{array}$ & 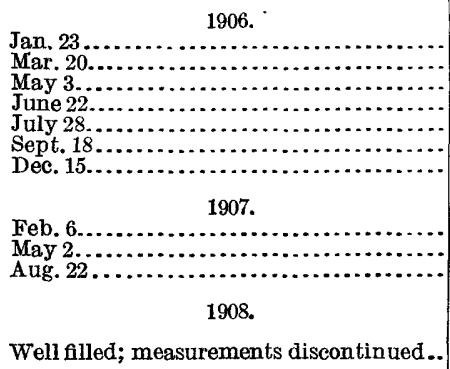 & $\begin{array}{cc}F t & \text { in. } \\
\mathbf{3 4} & \mathbf{1} \\
\mathbf{3 3} & \mathbf{3} \\
\mathbf{3 3} & 6 \\
\mathbf{3 3} & 11 \\
\mathbf{3 4} & 7 \frac{1}{2} \\
\mathbf{3 5} & 3 \\
\mathbf{3 4} & 9\end{array}$ \\
\hline
\end{tabular}


Records of water levels in the valley of southern California-Continued.

14. Artesian Land \& Water Co., Montelaire Street, three-fourths mile north of Cienega station, Santa Monica quadrangle.

[Bored well, 12 inches in diameter; altitude of surface, about 140 feet above sea level; method of lift, wind; use, domestic and stock. Water contains 520 parts per million of dissolved solids. Bench mark: Top of casing, 7 inches above surface. Well No. 46, Water-Supply Paper 139, p. 23.]

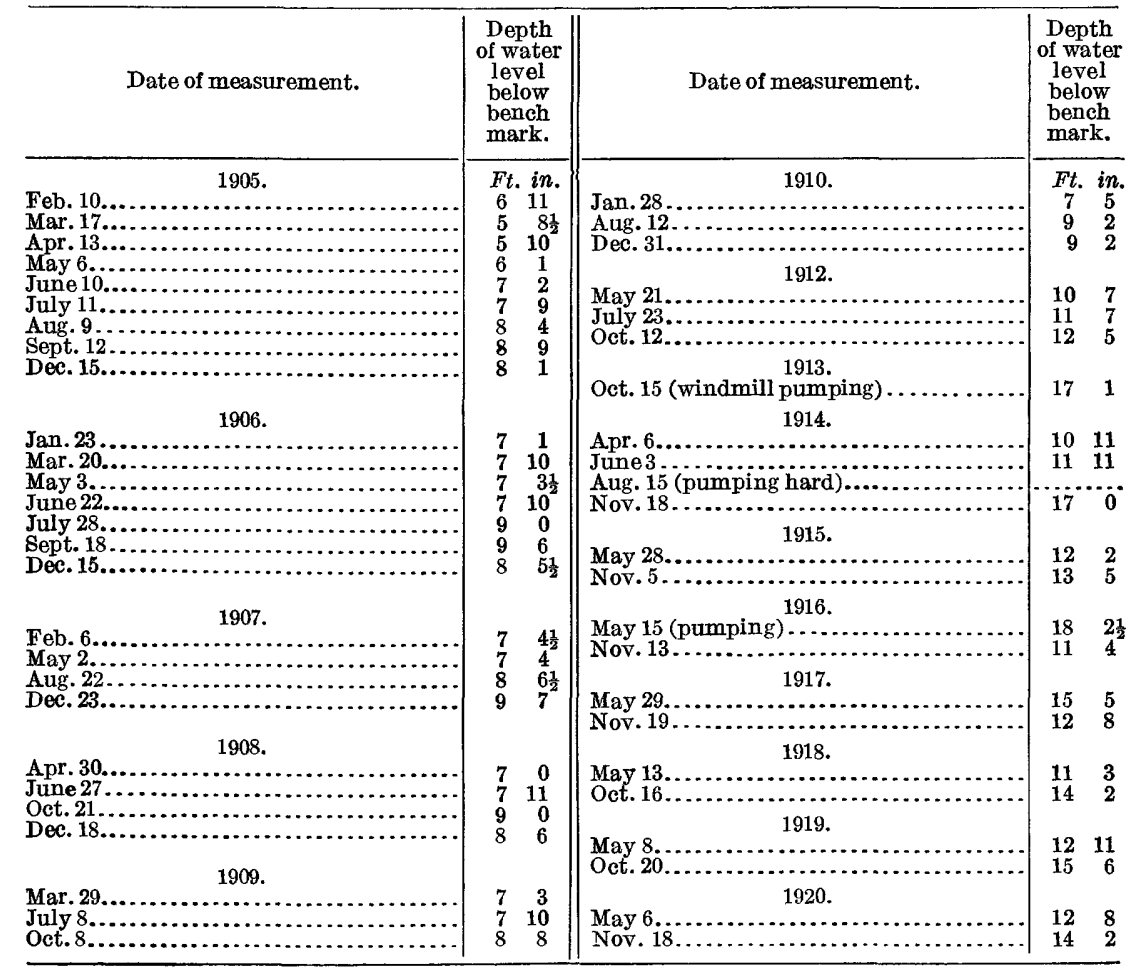

15. County well, Ivy station, Santa Monica quadrangle.

(Borea well, 47 feet deep, 7 inches in diameter; sunk in 1901; altitude of surface, about 102 feet above sea level; method of lift, wind; use, roads and stock. Water contains 770 parts per million of dissolved solids. Bench mark: Top of casing, 2 feet above surface. Well No. 606, Water-Supply Paper 139, p. 45.]

\begin{tabular}{|c|c|c|c|}
\hline Date of measurement. & $\begin{array}{l}\text { Depth } \\
\text { of water } \\
\text { level } \\
\text { below } \\
\text { bench } \\
\text { mark. }\end{array}$ & Date of measurement. & $\begin{array}{l}\text { Depth } \\
\text { of water } \\
\text { level } \\
\text { below } \\
\text { bench } \\
\text { mark. }\end{array}$ \\
\hline 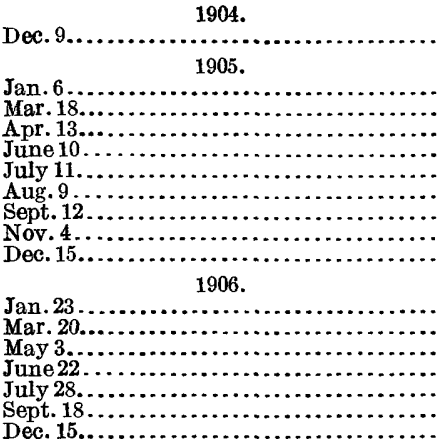 & $\begin{array}{cc}\text { Ft. } & \text { in } \\
13 & 11 \\
& \\
13 & 0 \\
12 & 1 \\
12 & 0 \\
12 & 3 \\
12 & 7 \\
13 & 0 \\
13 & 4 \frac{1}{2} \\
13 & 3 \\
13 & 3 \frac{1}{2} \\
& \\
13 & 1 \\
12 & 5 \\
12 & 2 \\
9 & 8 \frac{1}{2} \\
12 & 10 \\
13 & 3 \\
13 & 3 \frac{1}{2}\end{array}$ & 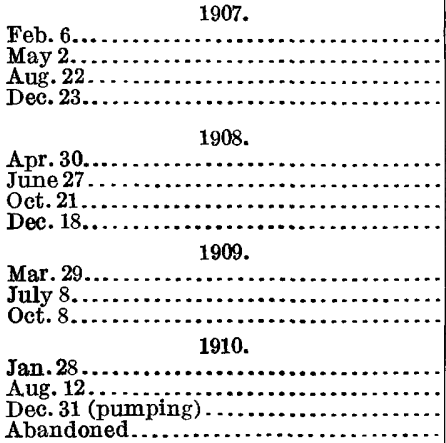 & \begin{tabular}{|cc}
12 & 4 \\
12 & 8 \\
13 & 4 \\
13 & 2 \\
& \\
11 & 7 \\
12 & 4 \\
13 & 0 \\
& \\
12 & 4 \\
13 & 1 \\
$\ldots \ldots . .$.
\end{tabular} \\
\hline
\end{tabular}


Records of water levels in the valley of southern California-Continued.

\section{M. P. Kane, Palms, Santa Monica quadrangle.}

[Bored well, about 250 feet deep, 7 inches in diameter; sunk in 1901; altitude of surface, about 125 feet above sea level; method of lift, wind; use, domestic. Water contains 650 parts per million of dissolved solids. Bench mark not known. Well No. 820, Water-Supply Paper 139, p. 53.]

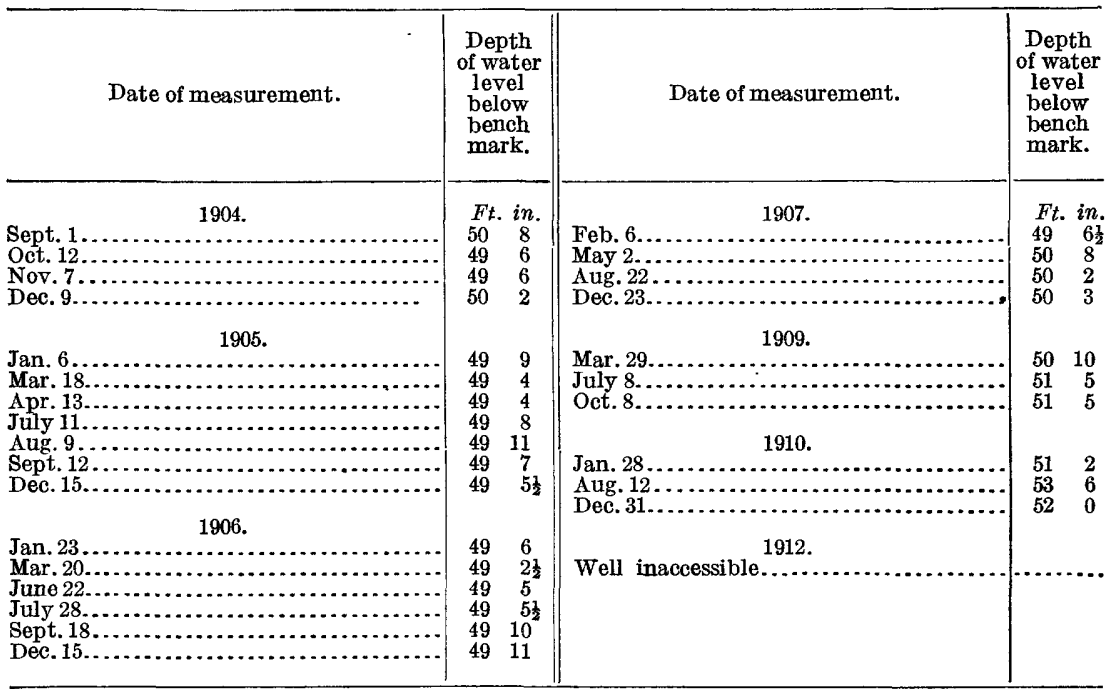

17. E. P. Bojorquez, Palms, Santa Monica quadrangle.

[Bored well, 66 feet deep, 7 inches in diameter; sunk in 1891; altitude of surface, about 100 feet above sea level; method of lift, wind; use, domestic. Water contains 300 parts per million of dissolved solids. Bench mark: Top of casing, 1 foot 8 inches above surface. Well No. 833, Water-Supply Paper 139, p. 54.]

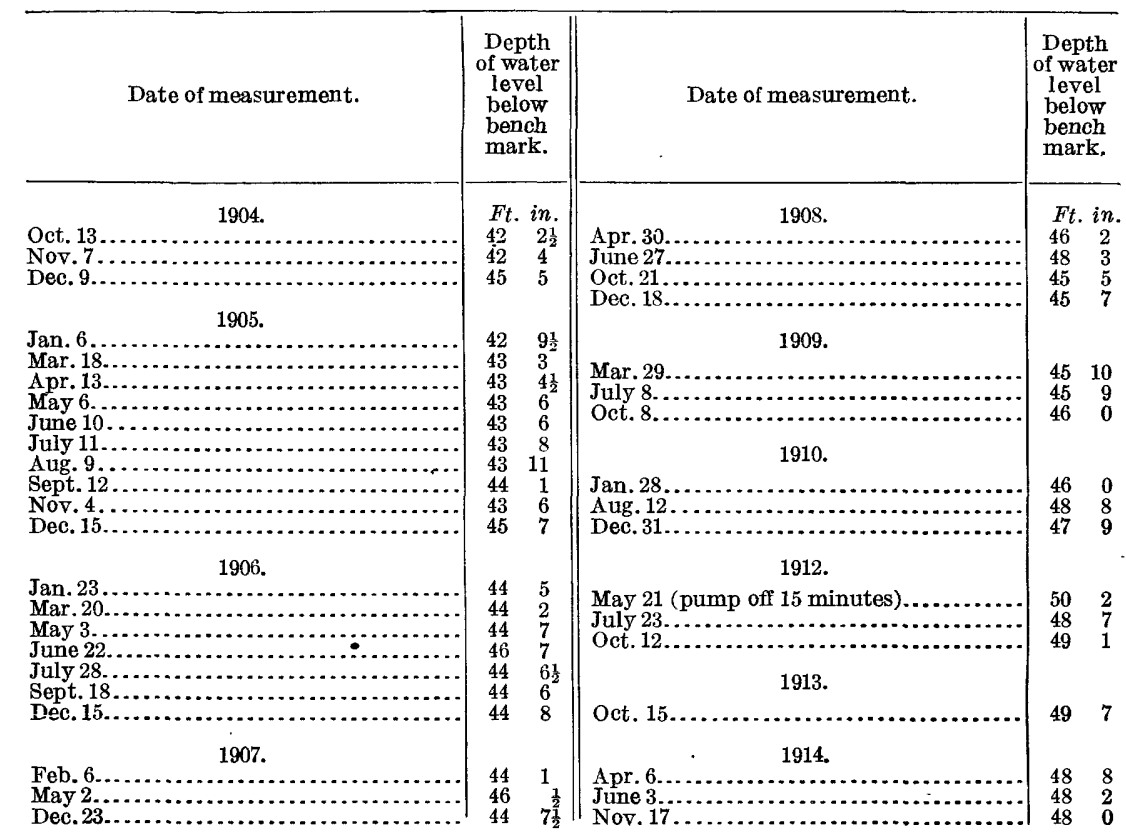


Records of water levels in the valley of southern California-Continued.

17. E. P. Bojorquez-Continued.

\begin{tabular}{|c|c|c|c|}
\hline Date of measurement. & $\begin{array}{c}\text { Depth } \\
\text { of water } \\
\text { level } \\
\text { below } \\
\text { bench } \\
\text { mark. }\end{array}$ & Date of measurement. & $\begin{array}{l}\text { Depth } \\
\text { of water } \\
\text { level } \\
\text { below } \\
\text { bench } \\
\text { mark. }\end{array}$ \\
\hline $\begin{array}{l}1915 . \\
\text { May } 28 \text { (pumping slowly) } \ldots \ldots \ldots \ldots \ldots \ldots \ldots \\
\text { Nov. } 5 . \ldots \ldots \ldots \ldots \ldots \ldots \ldots \ldots \ldots \ldots \ldots \ldots \ldots \ldots\end{array}$ & $\begin{array}{ll}\text { Ft. in. } \\
50 & 7 \\
48 & 9\end{array}$ & $\begin{array}{l}\text { 1918. } \\
\text { May } 13 \text { (gasoline pump working) ......... } \\
\text { Oct. } 16 . \ldots \ldots \ldots\end{array}$ & \begin{tabular}{l} 
Ft. in. \\
\hdashline $6^{2}$ i
\end{tabular} \\
\hline $\begin{array}{l}1916 . \\
\text { May } 15 \text { (gas engine installed) } \ldots \ldots \ldots \ldots \ldots \ldots \\
\text { Nov. } 13 \ldots \ldots \ldots \ldots \ldots \ldots \ldots \ldots \ldots \ldots \ldots \ldots \ldots \ldots\end{array}$ & $\begin{array}{ll}47 & 5 \\
46 & 7\end{array}$ & $\begin{array}{c}1919 . \\
\text { May } 8 \ldots \ldots \ldots \ldots \ldots \ldots \ldots \ldots \ldots \ldots \ldots \ldots\end{array}$ & $\begin{array}{lr}47 & 11 \\
48 & 5\end{array}$ \\
\hline 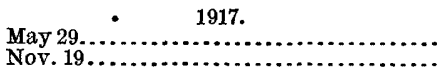 & $\begin{array}{ll}48 & 0 \\
48 & 2\end{array}$ & 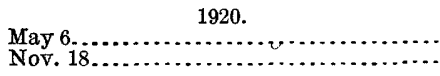 & $\begin{array}{ll}48 & 8 \\
48 & 0\end{array}$ \\
\hline
\end{tabular}

18. G. A. Cortelyou (formerly owned by Jose Sesma), 1 mile north of Ivy station, Santa Monica quadrangle.

[Bored well, 50 feet deep, 7 inches in diameter; sunk in 1893; altitude of surface, about 160 feet above sea level; method of lift, wind; use, domestic. Water contains 790 parts rer million of dissolved solids. Bench mark: Top of casing, 1 foot 4 inches above surface. Well No. 661, Water-Supply Paper 139, p. 47.]

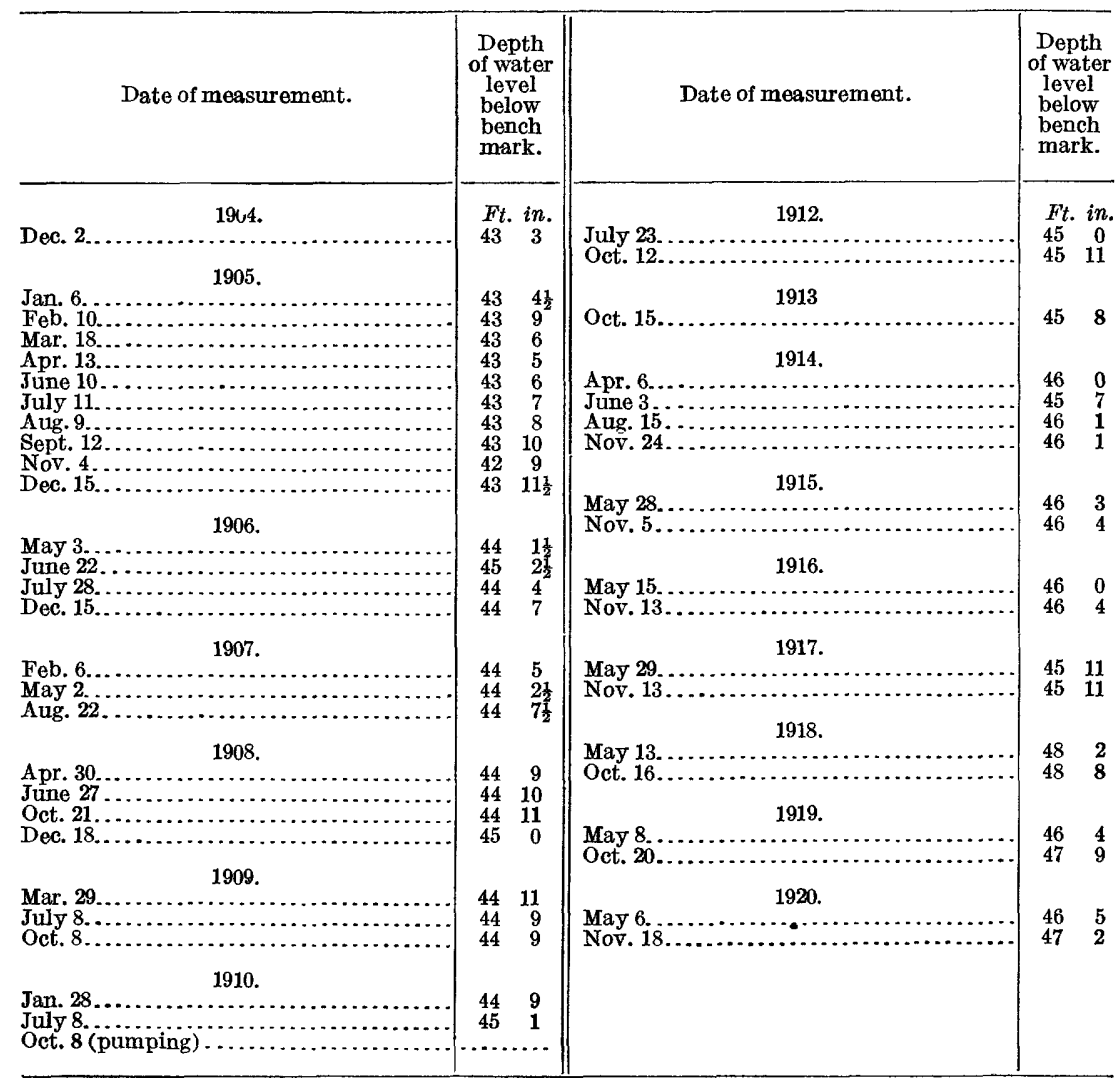


Records of water levels in the valley of southern California-Continued.

18a. H. R. Brinkerhoff (formerly owned by M. Arnez), 1 mile north of Ivy station, Santa Monica quadrangle.

[Bored well, 70 feet deep, 7 inches in diameter; altitude of surface, about 170 feet above sea level; method of lift, wind; use, domestic. Water contains 800 parts per million of dissolved solids. Bench mark: Top of casing, 1 foot 2 inches above surface. Well No. 662, Water-Supply Paper 139, p. 47. Companion well for No. 18.]

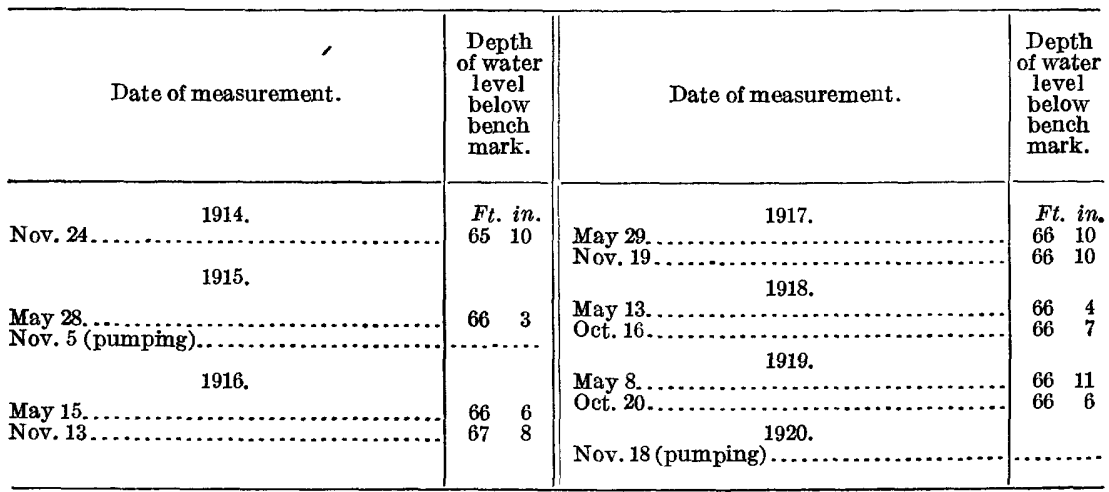

19. J. H. Whitworth, 2 miles south of Sherman, Santa Monica quadrangle.

[Bored well, 61 feet deep, 6 inches in diameter; sunk in 1887; altitude of surface, about 125 feet above sea level; method of lift, wind; use, domestic. Water contains 800 parts per million of dissolved solids. Bench mark: Top of casing, 6 inches above surface. 'Well No. 514, Water-Supply Paper 139, p. 42.]

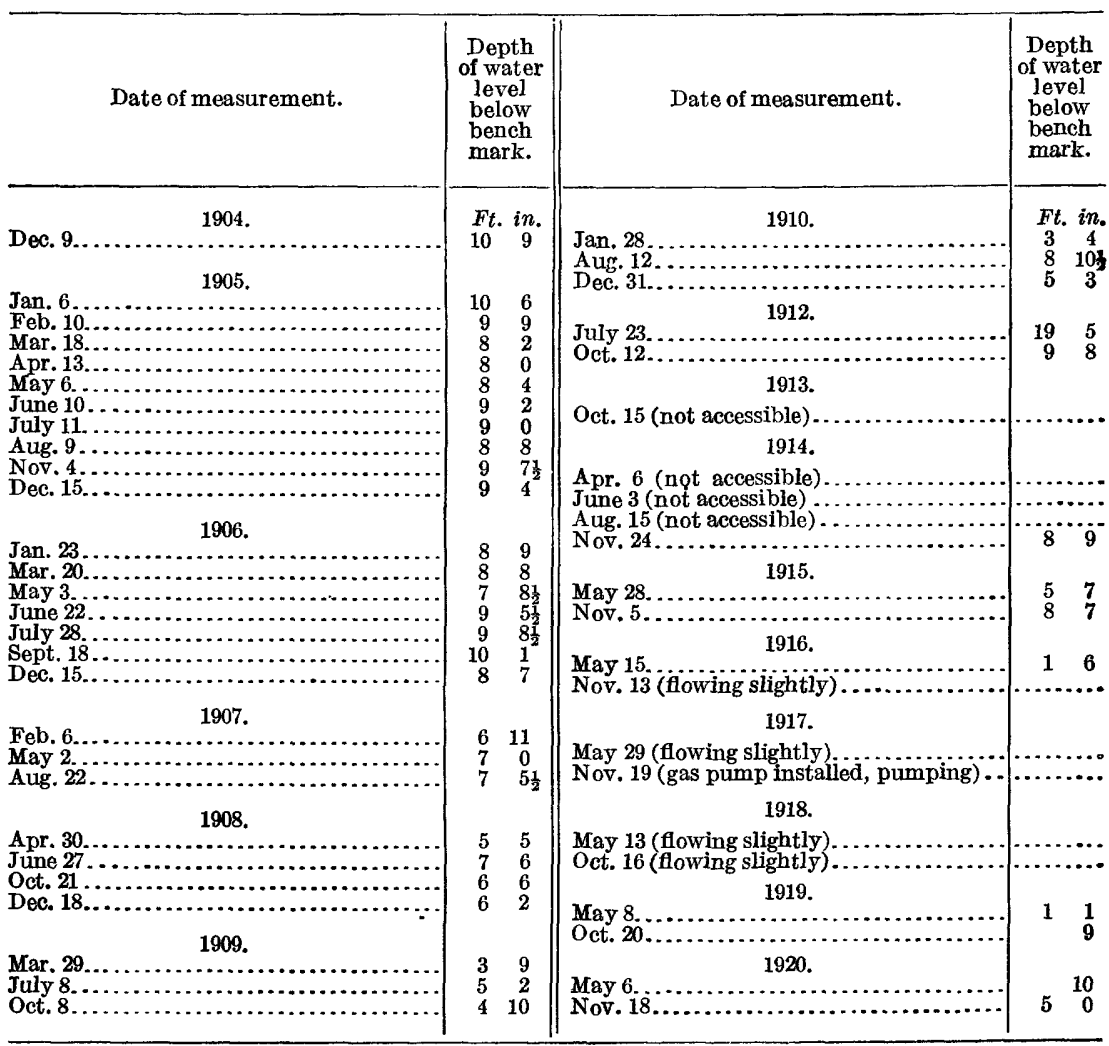


Records of water levels in the valley of southern California-Continued.

20. Hammel \& Decker, 1 mile south of Sherman, Santa Monica quadrangle.

[Bench mark not known.]

\begin{tabular}{|c|c|c|c|}
\hline Date of measurement. & $\begin{array}{c}\text { Depth } \\
\text { of water } \\
\text { level } \\
\text { below } \\
\text { bench } \\
\text { mark. }\end{array}$ & Date of measurement. & $\begin{array}{l}\text { Depth } \\
\text { of water } \\
\text { level } \\
\text { below } \\
\text { bench } \\
\text { mark. }\end{array}$ \\
\hline 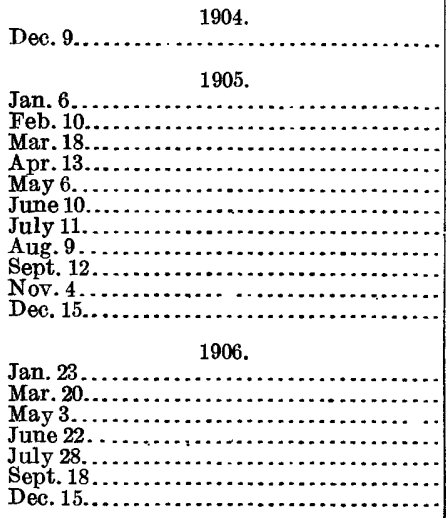 & $\begin{array}{cc} & \\
13 & 6 \\
12 & 11 \frac{1}{2} \\
11 & 9 \\
11 & 6 \\
11 & 7 \\
11 & 10 \\
12 & 1 \\
12 & 4 \\
12 & 10 \\
13 & 0 \\
12 & 10\end{array}$ & 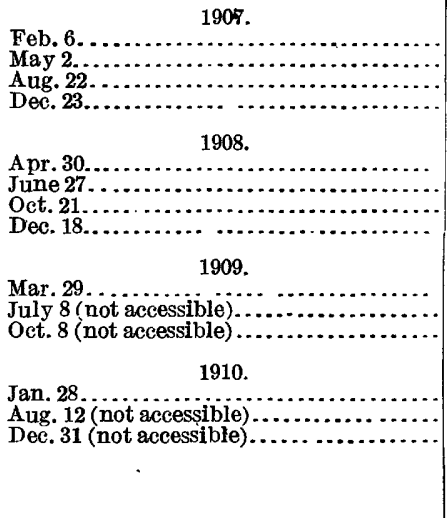 & $\begin{array}{cc}10 & 8 \\
11 & 2 \\
12 & 0 \\
29 & 1 \\
& \\
& \\
24 & 9 \\
\ldots \ldots \ldots \ldots\end{array}$ \\
\hline
\end{tabular}

21. William Niles, three-fourths mile south of Sherman, Santa Monica quadrangle.

[Bored well, 150 feet deep, 14 inches in diameter; altitude of surface, about 170 feet above sea level; method of lift, wind; use, domestic. Water contains 1,030 parts per million of dissolved solids. Bench mark: Top of board curbing, 2 feet 4 inches above surface. Well No. 518, Water-Supply Paper 139, p. 42.]

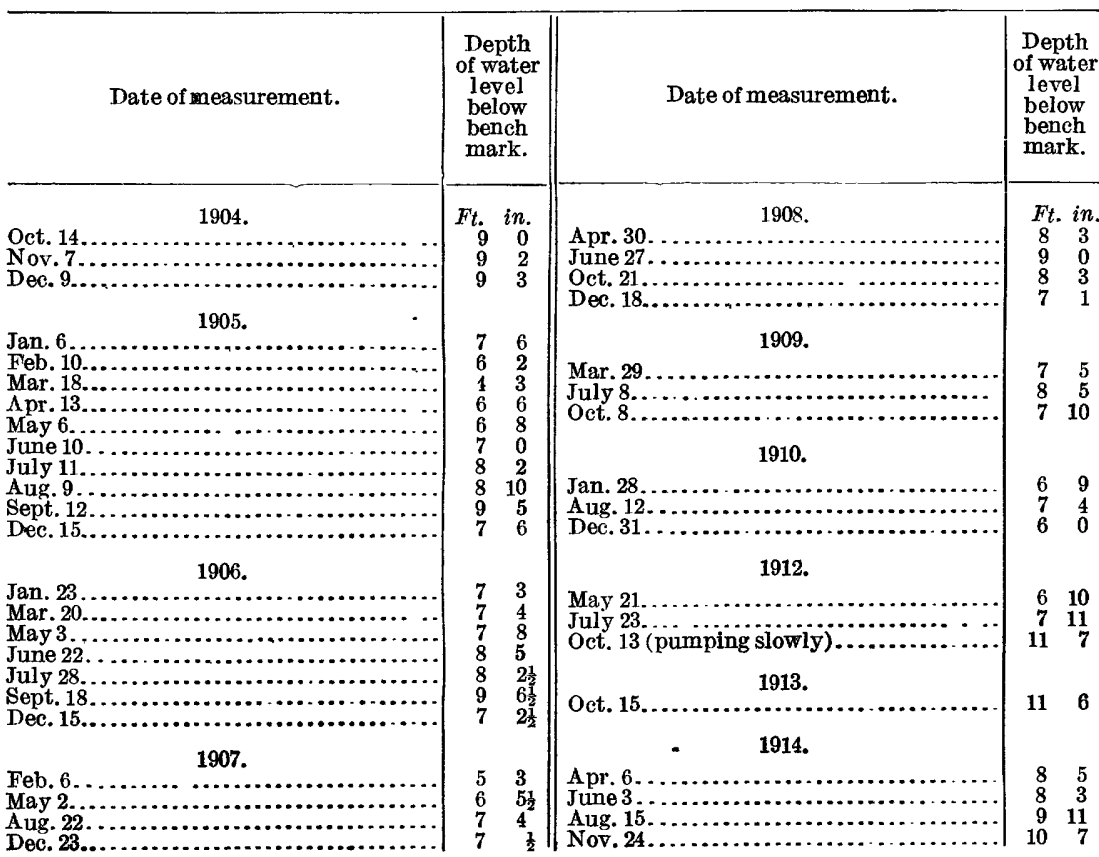


Records of water levels in the valley of southern California-Continued.

21. William Niles-Continued.

\begin{tabular}{|c|c|c|c|}
\hline Date of measurement. & $\begin{array}{c}\text { Depth } \\
\text { of water } \\
\text { level } \\
\text { below } \\
\text { beneh } \\
\text { mark. }\end{array}$ & Date of measurement. & $\begin{array}{c}\text { Depth } \\
\text { of water } \\
\text { level } \\
\text { below } \\
\text { bench } \\
\text { mark. }\end{array}$ \\
\hline 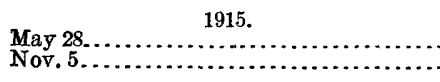 & $\begin{array}{cc}\text { Ft. } & \text { in. } \\
7 & 6 \\
9 & 4\end{array}$ & 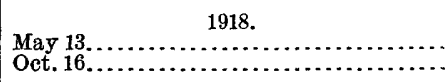 & $\begin{array}{ll}\text { Ft. } & \text { in. } \\
5 & 10 \\
5 & 10\end{array}$ \\
\hline 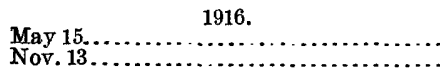 & $\begin{array}{ll}6 & 8 \\
6 & 4\end{array}$ & 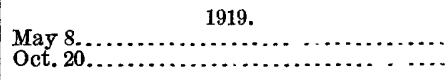 & $\begin{array}{rr}4 & 10 \\
5 & 2\end{array}$ \\
\hline 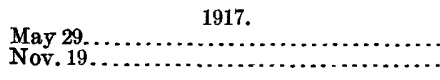 & $\begin{array}{l}6 \\
5\end{array}$ & $\begin{array}{l}\text { May } 6 \ldots 20 . \\
\text { Nov. } 18 \ldots \ldots \ldots \ldots \ldots \ldots \ldots \ldots \ldots \ldots \ldots \ldots \ldots \ldots \ldots \ldots \ldots \ldots\end{array}$ & $\begin{array}{l}5 \\
4\end{array}$ \\
\hline
\end{tabular}

22. County well, 1 mile east of Sherman, Santa Monica quadrangle.

[Bored well, 102 feet deep, 7 inches in diameter; altitude of surface, about 295 feet above sea level; method of lift, wind; use domestic. Water contains 530 parts per million of dissolved solids. Bench mark not known. Well No. 616, Water-Supply Paper 139, p. 45.]

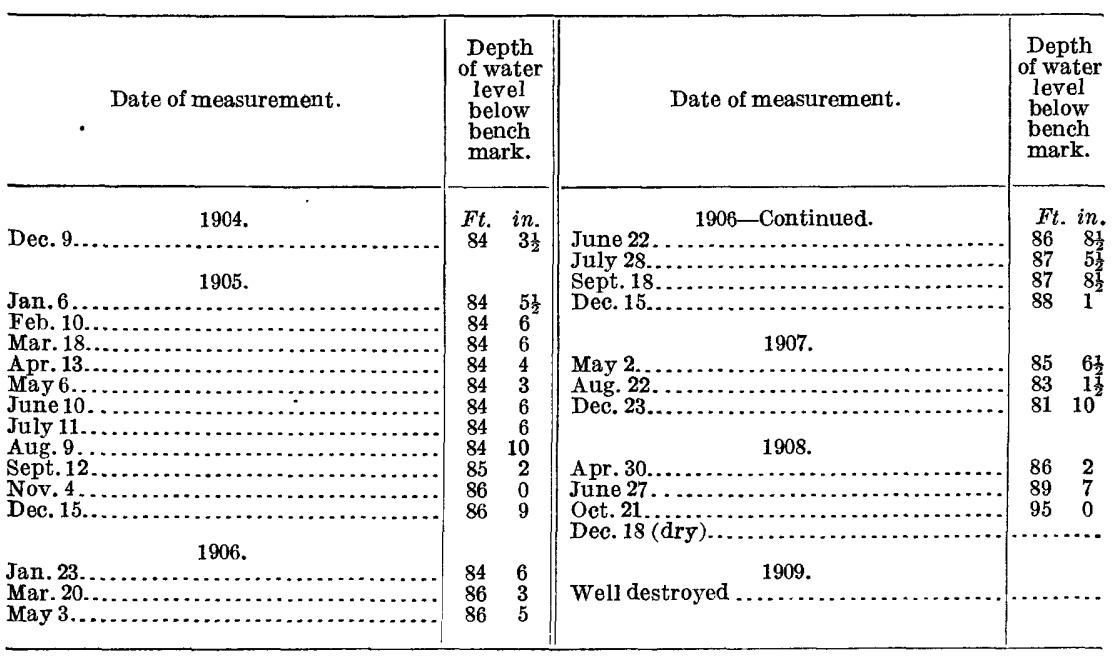


Records of water levels in the valley of southern California-Continued.

22a. H. E. Lodge, 6010 Willoughby Avenue, Hollywood, Santa Monica quadrangle.

[Bored well, 52 feet deep; 7 inches in diameter; method of lift, wind; use, domestic. Bench mark: Top of casing, level with surface. Measured in conjunction with observation wells but reeord not published heretofore.]

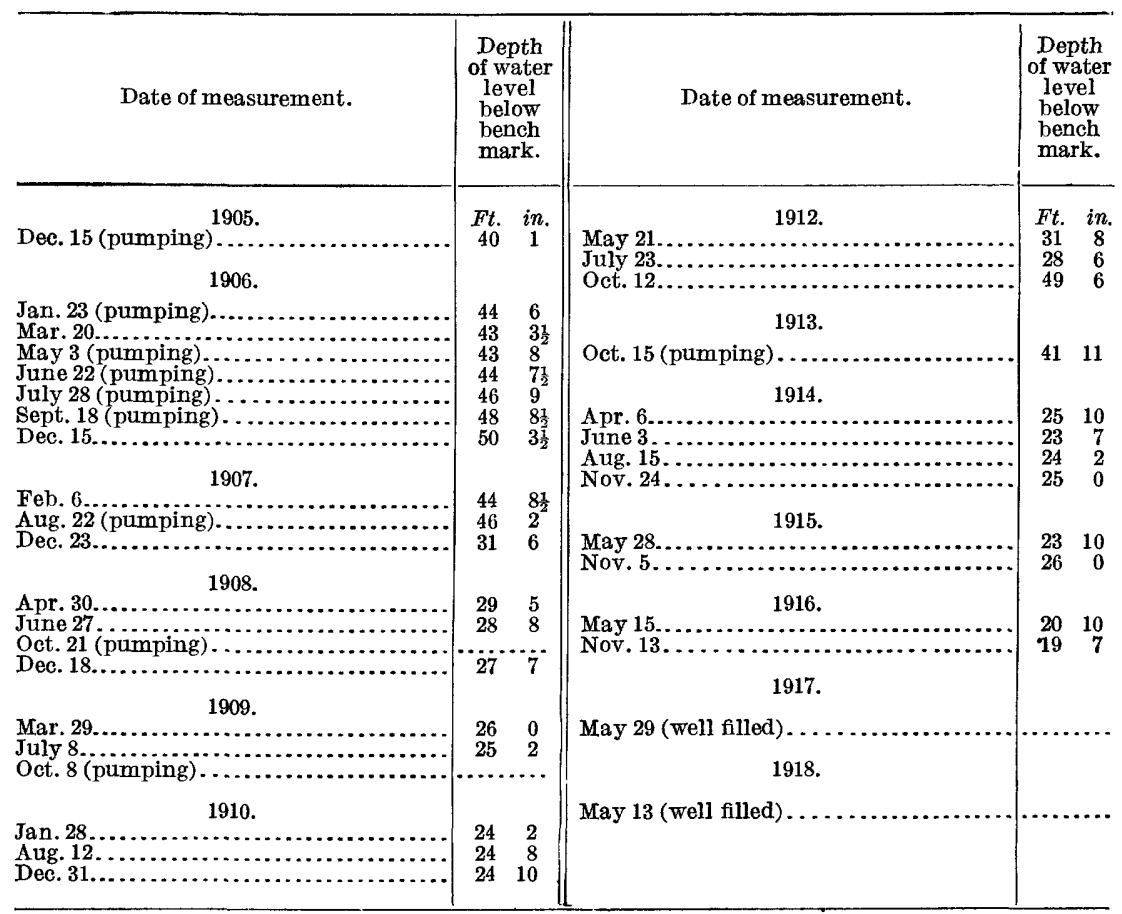

22b. Mrs. Sesma, corner Willoughby Avenue and Seward Street, Hollywood, Santa Monica quadrangle.

[Companion well for No. 22a. Bench mark: Top of casing, 2 feet above surface.]

\begin{tabular}{|c|c|c|c|}
\hline Date of measurement. & $\begin{array}{c}\text { Depth } \\
\text { of water } \\
\text { level } \\
\text { below } \\
\text { bench } \\
\text { mark. }\end{array}$ & Date of measurement. & $\begin{array}{l}\text { Depth } \\
\text { of water } \\
\text { level } \\
\text { below } \\
\text { bench } \\
\text { mark. }\end{array}$ \\
\hline 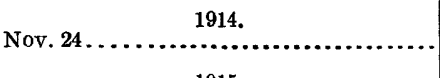 & $\begin{array}{l}\text { Ft. } \\
17\end{array}$ & $\begin{array}{l}\text { May } 29 \ldots \ldots \ldots \ldots \ldots \ldots \ldots \ldots \ldots \ldots \ldots \ldots \ldots \\
\text { Nov. } 19 . \ldots \ldots \ldots \ldots \ldots \ldots \ldots \ldots \ldots \ldots \ldots\end{array}$ & $\begin{array}{cc}\text { Ft. } & \text { in } \\
13 & 11 \\
14 & 0\end{array}$ \\
\hline 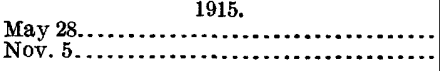 & $\begin{array}{rr}16 & 11 \\
18 & 7\end{array}$ & $\begin{array}{c}1918 . \\
\text { May } 13 \ldots \ldots \ldots \ldots \ldots \ldots \ldots \ldots \ldots \ldots\end{array}$ & 149 \\
\hline $\begin{array}{c}1916 . \\
\text { May } 15 \ldots \ldots \ldots \ldots \ldots \ldots \ldots \ldots \ldots \ldots \ldots \ldots \ldots \ldots \ldots \ldots \ldots \ldots \ldots \ldots\end{array}$ & $\begin{array}{ll}15 & 8 \\
15 & 3\end{array}$ & May 8 (well destroyed) ..... & \\
\hline
\end{tabular}


Records of water levels in the valley of southern California-Continued.

22c. H. A. Slack, 5310 Santa Monica Boulevard, Hollywood, Santa Monica quadrangle.

[Open well, 63 feet deep, 4 feet in diameter; method of lift, wind; use, domestic. Bench mark: Top of 4 by 6 across curb, 2 inches above surface. Has been measured in conjunction with obsorvation wells but record not published heretofore.]

\begin{tabular}{|c|c|c|c|}
\hline Date of measurement. & $\begin{array}{l}\text { Depth } \\
\text { of water } \\
\text { level } \\
\text { pelow } \\
\text { bench } \\
\text { mark. }\end{array}$ & Date of measurement. & $\begin{array}{c}\text { Depth } \\
\text { of water } \\
\text { level } \\
\text { below } \\
\text { bench } \\
\text { mark. }\end{array}$ \\
\hline 1906. & Ft. in. & 1913. & Ft. in. \\
\hline $\begin{array}{l}\text { July } 28 \ldots \ldots \ldots \ldots \ldots \ldots \\
\text { Dec. } 15 \ldots \ldots \ldots\end{array}$ & $53 \quad 5$ & Oct. $15 \ldots \ldots \ldots \ldots . . . .$. & 437 \\
\hline 1907. & & 1914. & \\
\hline Feb.6........ & $44 \quad 6 \frac{1}{3}$ & 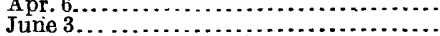 & $\begin{array}{ll}34 & 0 \\
39 & 4\end{array}$ \\
\hline 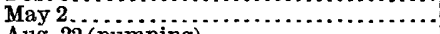 & 425 & Aug. 15 (pumping hard) & $\cdots \cdots \cdots$ \\
\hline $\begin{array}{l}\text { Aug. } 22 \text { (pumping) } \ldots \ldots \\
\text { Diec. } 23, \ldots \ldots \ldots \ldots \ldots \ldots \\
\end{array}$ & $\begin{array}{ll}47 & 9 \frac{1}{2} \\
42 & 10\end{array}$ & Nov. $23 . . . \ldots \ldots$ & $36 \quad 4$ \\
\hline 1908. & & May $28 \ldots \ldots \ldots \ldots \ldots$. & 38 \\
\hline $\begin{array}{l}\text { Apr. } 30 \ldots \ldots \\
\text { June } 27 . \ldots \ldots\end{array}$ & $\begin{array}{ll}42 & 0 \\
43 & 5\end{array}$ & Nov. $5 . \ldots \ldots \ldots \ldots . . . .$. & 36 \\
\hline Oct. $21 \ldots . .$. & 430 & 1916. & \\
\hline Dèc. $18 \ldots . .$. & 4211 & $\begin{array}{l}\text { May } 15, \ldots \ldots \\
\text { Nov, } 13 . \ldots \ldots\end{array}$ & $\begin{array}{l}32 \\
32\end{array}$ \\
\hline Mar. 29....... & 410 & 1917. & \\
\hline $\begin{array}{l}\text { July } 8, \ldots \ldots \ldots \ldots \ldots \ldots \\
\text { Oct. } 8, \ldots \ldots \ldots \ldots \ldots \ldots \ldots \ldots\end{array}$ & $\begin{array}{ll}41 & 1 \\
41 & 1\end{array}$ & May 29 (well flled) .............................. & \\
\hline $\operatorname{Jan} 28$. & 11 & 1918. & \\
\hline $\begin{array}{l}\text { Aug. } 12 \text { (pumping) } \\
\text { Dec. } 31 . \ldots\end{array}$ & $\begin{array}{rr}40 & 11 \\
45 & 0 \\
40 & 11\end{array}$ & May 13 (well filled)... & n........ \\
\hline 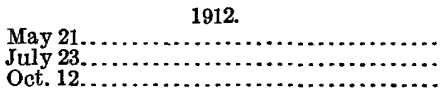 & $\begin{array}{ll}38 & 1 \\
39 & 1 \\
41 & 2\end{array}$ & & \\
\hline
\end{tabular}

23. F. E. Wilcox (formerly owned by Mr. Hurlbut), Orange Grove Avenue, Pasadena, Pasadena quadrangle.

[Bored well, 1,300 feet deep, 7 inches in diameter; altitude of surface, about 816 feet above sea level; water not used. Bench mark: Top of casing, level with surface. Well No. 56, Water-Supply Paper 219, p. 162.]

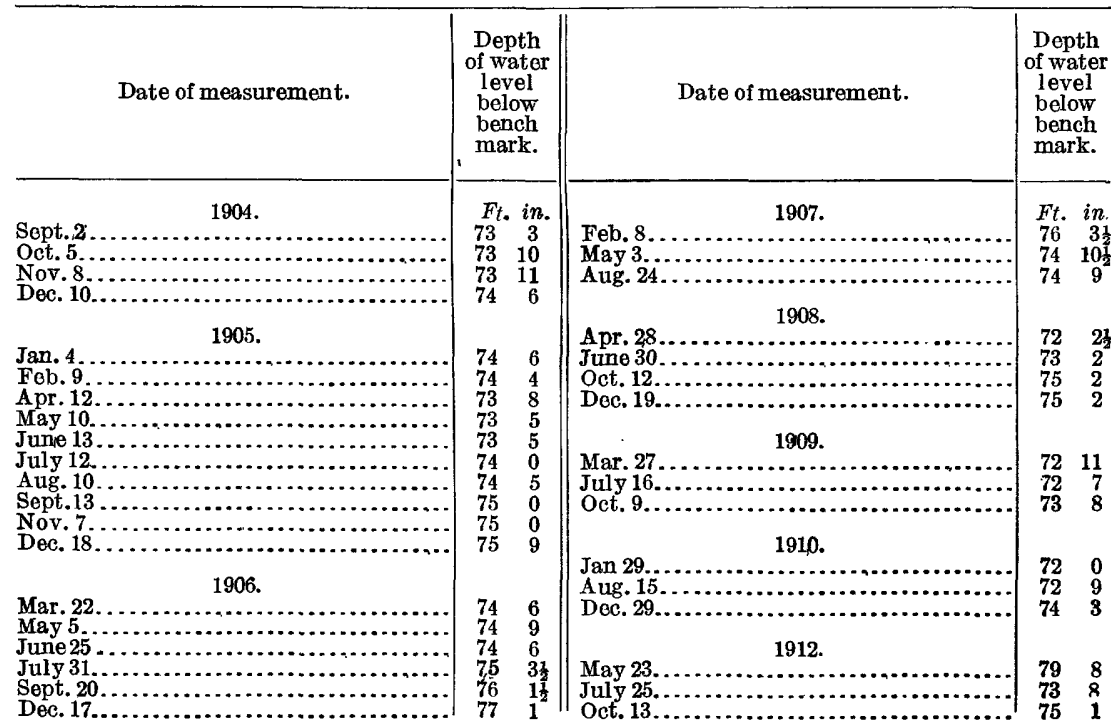


Records of water levels in the valley of southern California-Continued.

23. F. E. Wilcox-Continued.

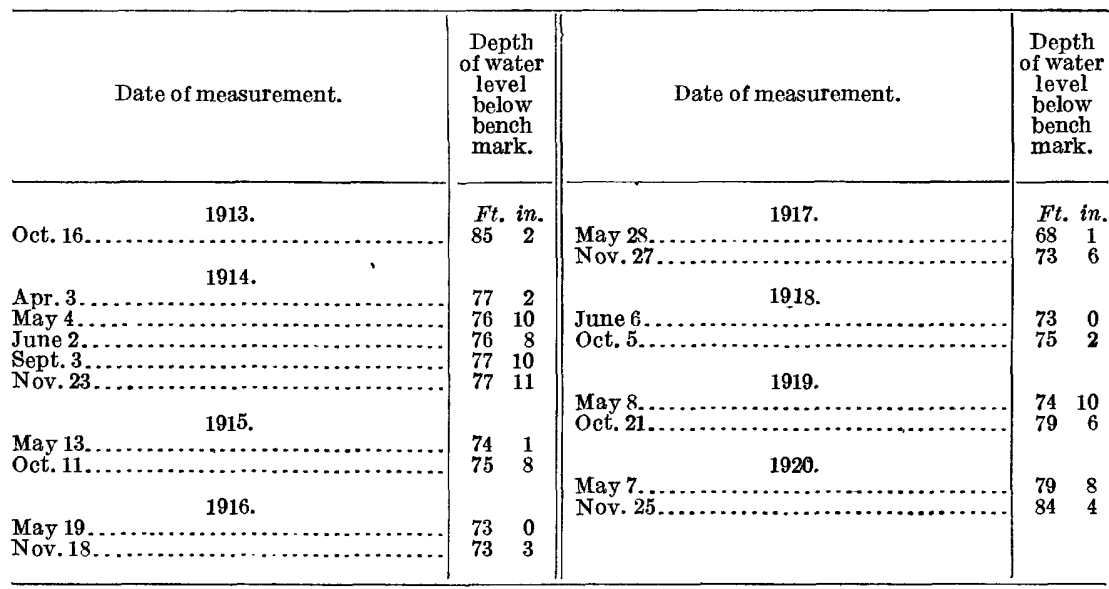

24. L. V. Harkness, southwest corner Colorado Street and Sierra Bonita Avenue, Pasadena, Pasadena quadrangle.

[Bored well, 272 feet deep, 12 inches in diameter; altitude of surface, ahout 787 feet above sea level; water not used. Bench mark not known. Well No. 17, Water-Supply Paper 219, p. 161.]

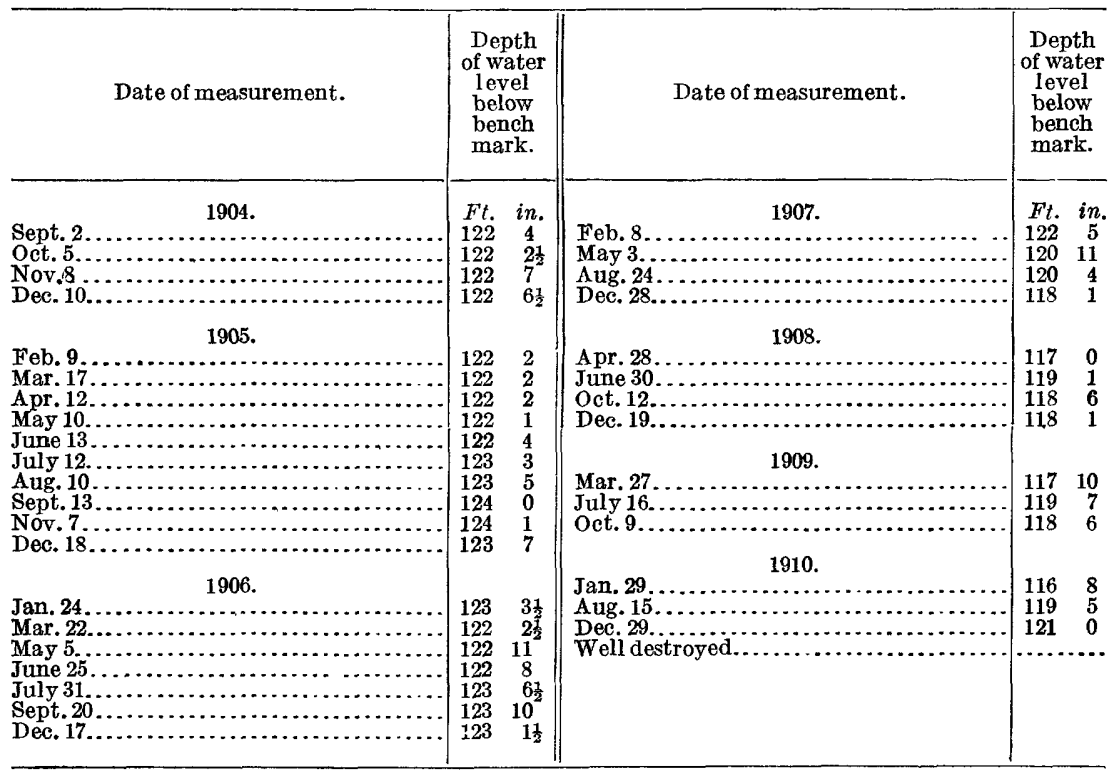


Records of water levels in the valley of southern California-Continued.

24a. Mr. Hislop (formerly owned by I. McCollum), southeast corner Colorado Street and Sierra Bonita Arenue, Pasadena, Pasadena quadrangle.

[Well, 151 feet deep; altitude of surface, about 785 feet above sea level; method of lift, wind; use, domestic andirrigation. Bench mark: Top of casing, 1 foot 3 inches above surface. Well No. 12, Water-Supply Paper 219, p. 161 . Companion well for No. 24. Has been measured in conjunction with observation wells, but record not published heretofore.]

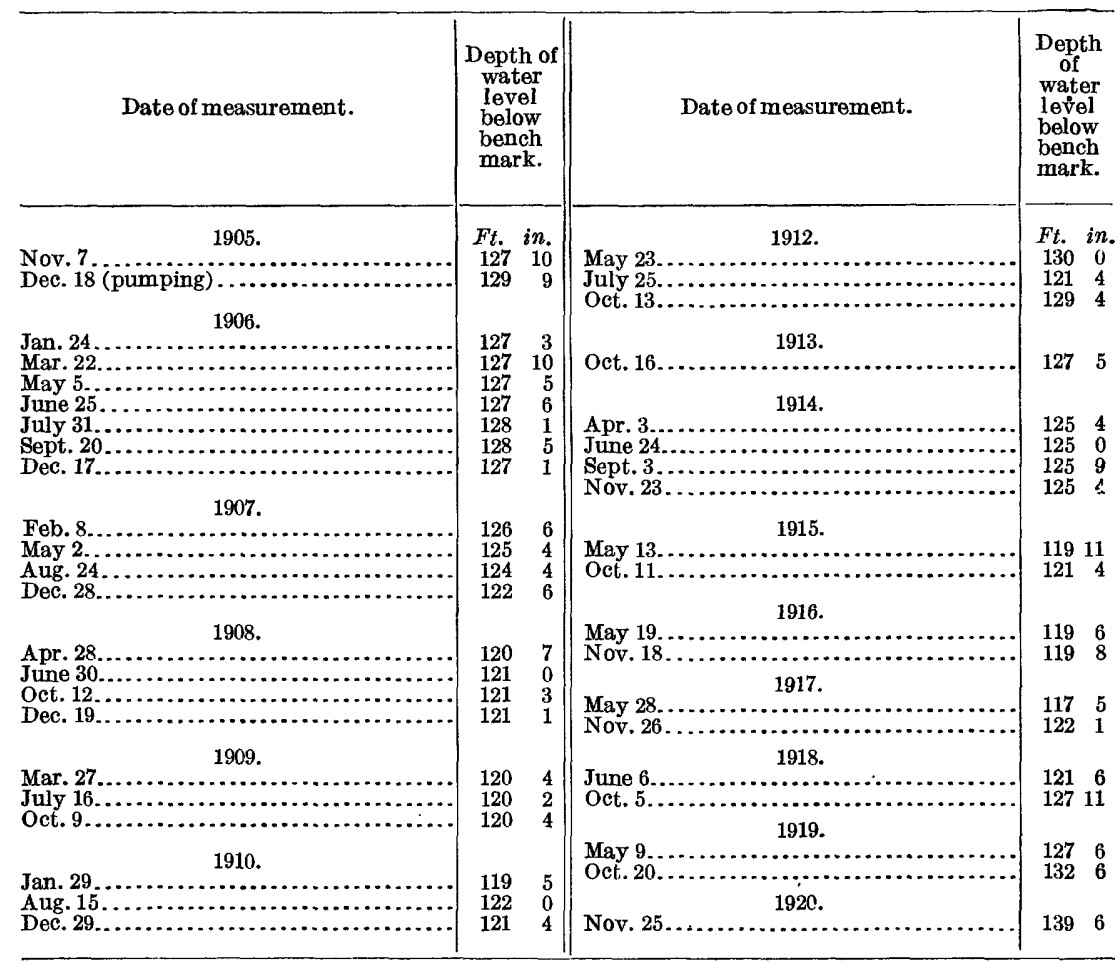

25. Titus ranch, Sunny Slope station, Pasadena quadrangle.

[Bored well, 132 feet deep, 7 inches in diameter; altitude of surface, about 620 feet above sea level; water not used. Bench mark not known. Well No. 475, Water-Supply Paper 219, p. 175.]

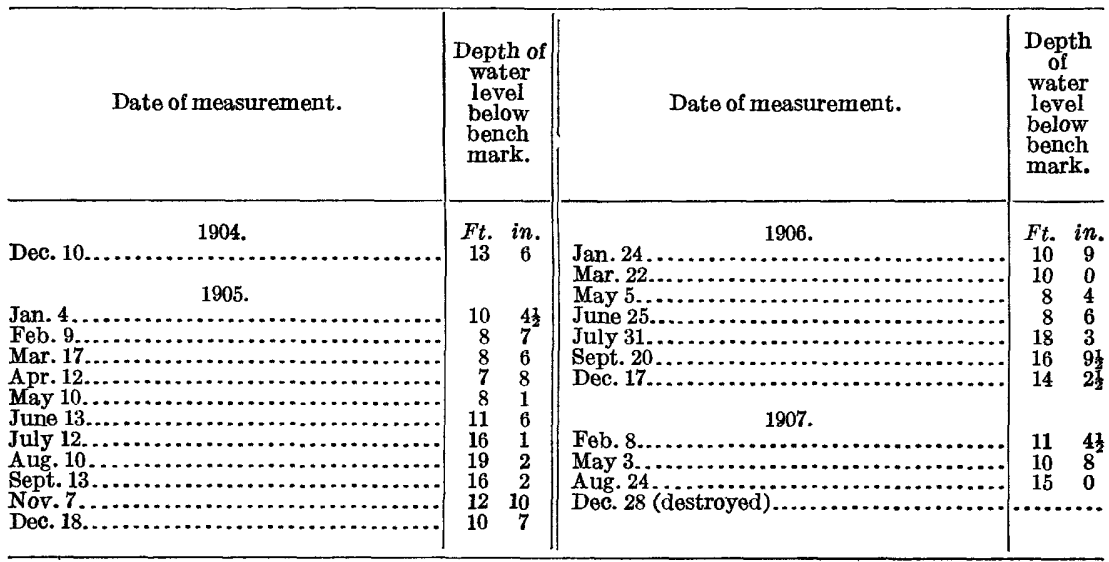




\section{Records of water levels in the valley of southern California-Continued.}

26. John MeClain estate, 1 mile south of San Gabriel, Pasadena quadrangle.

[Bored well,130feet deep, 7 inches in diameter; sunk in 1896; altitude of surface, about 342 feet above sea level; method of lift, wind; use, domestic. Bench mark not known. Well No. 107, Water-Supply Paper 219, p. 163.]

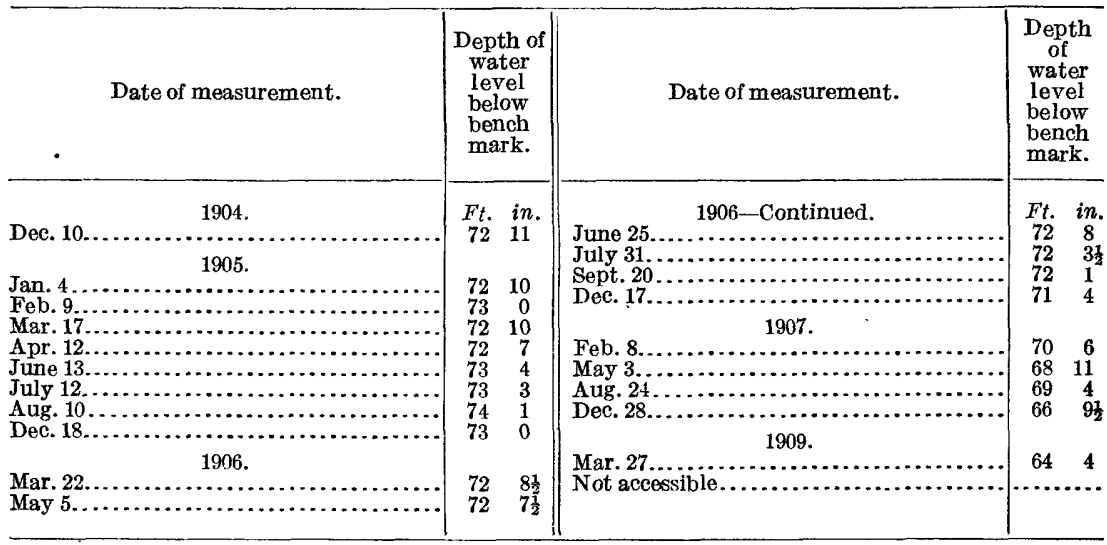

27. W. S. Torbert (formerly owned by F. E. Wilson), 2 miles south of San Gabriel, Pasadena quadrangle.

[Bored well, 36 feet deep, 6 inches in diameter; sunk in 1901; altitude of surface, about 287 feet above see level; method of lift, wind; use, domestic. Bench mark: Top of casing, originally 1 foot 8 inches above surface. Between Nov. 20, 1917, and May 11, 1918, 1 foot of casing was removed. Beginning with May $11,1918,1$ foot has been added to the measurements to make them comparable with earlier measurements. Well No. 102, Water-Supply Paper 219, p. 163.]

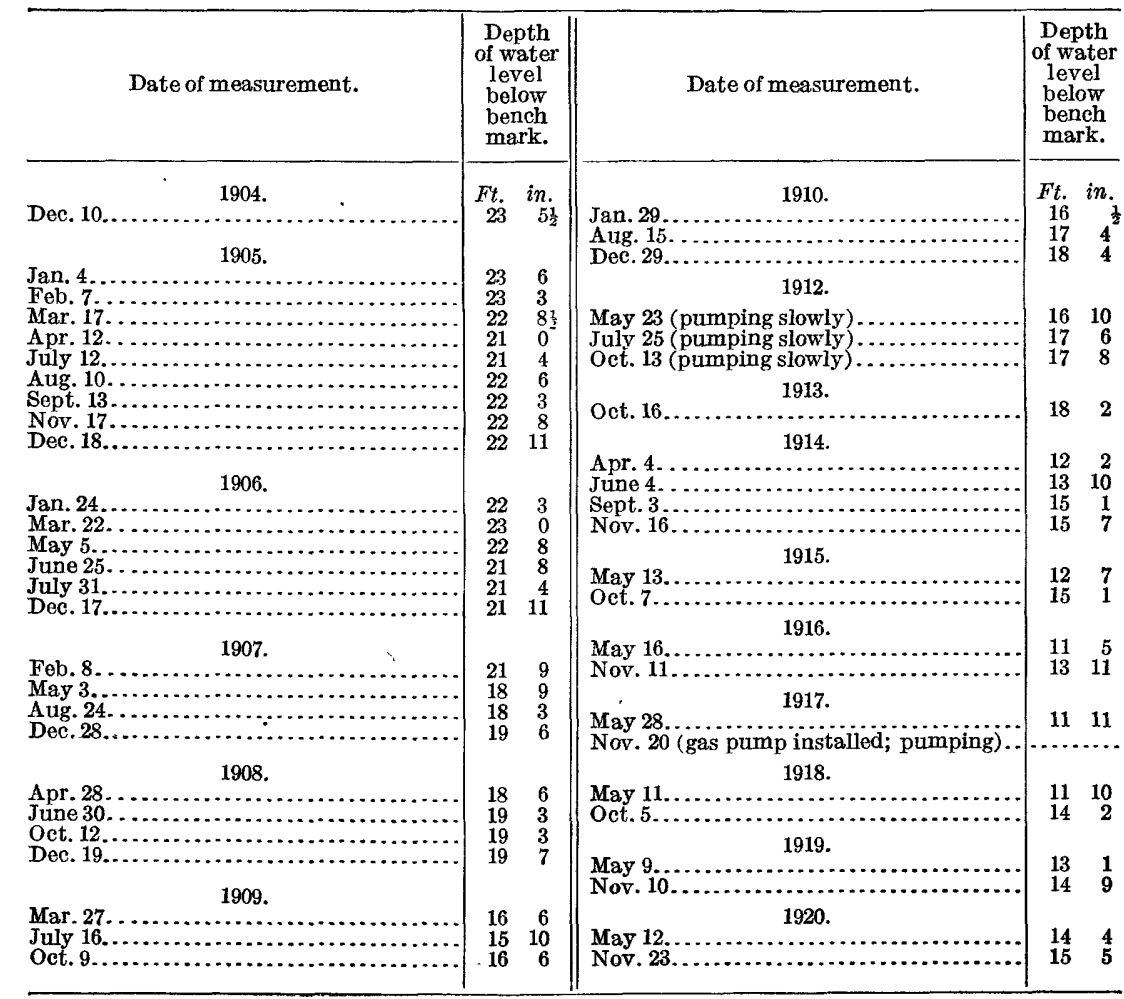


Records of water levels in the valley of southern California-Continued.

28. G. B. Renfro, three-fourths mile southwest of Savannah, Pasadena quadrangle.

[Bored well, 46 feet deep, 7 inches in diameter; altitude of surface, about 300 feet above sea level; method of lift, wind; use, domestic. Bench mark: Top of casing, level with surface. Well No. 476, WaterSupply Paper 219, p. 175.]

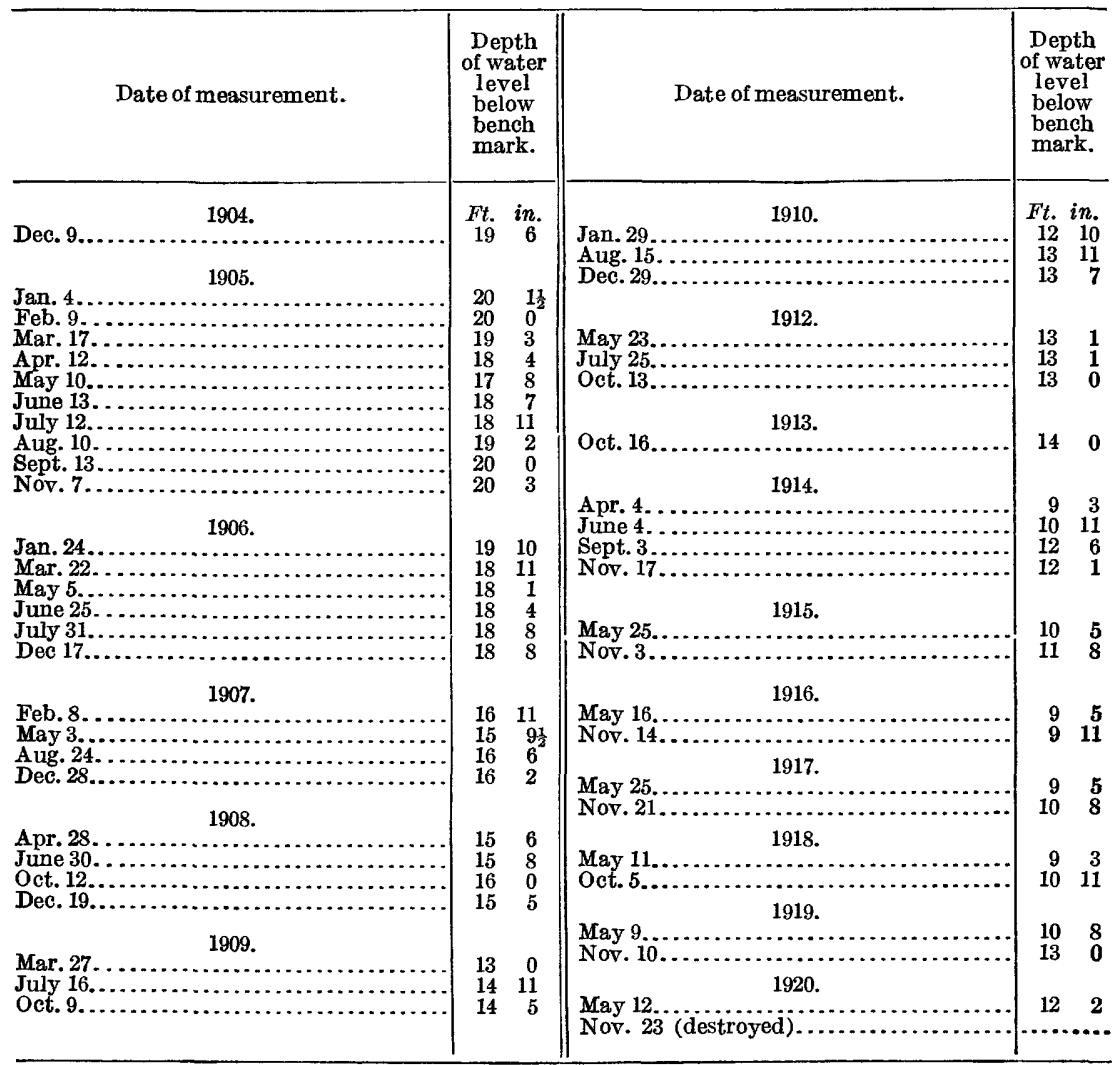

28a. G. B. Renfro, three-fourths mile southwest of Savannah, Pasadena quadrangle.

[Dug well, 5 feet in diameter for 24 feet, then 12-inch bore for 63 feet. Method of lift, wind and gasoline engine; use, irrigation and domestic; situated 50 feet south of well No. 28. Bench mark: Originally bottom of a 10 by $10 \mathrm{inch}$ timber across curb, 4 inches below surface. Between May 26, 1917, and May 11, 1918 , the 10 by 10 inch timber was removed. A new bench mark was established as the top of the west side of the curb, about 1 foot 4 inches higher than the original bench mark. An addition of 1 foot 4 inches has been made to all measurements previous to May 11, 1918, to make them comparable with measurements from the present bench mark.]

\begin{tabular}{|c|c|c|c|}
\hline Date of measurement. & $\begin{array}{c}\text { Depth } \\
\text { of water } \\
\text { level } \\
\text { below } \\
\text { bench } \\
\text { mark. }\end{array}$ & Date of measurement. & $\begin{array}{l}\text { Depth } \\
\text { of water } \\
\text { level } \\
\text { below } \\
\text { bench } \\
\text { mark. }\end{array}$ \\
\hline 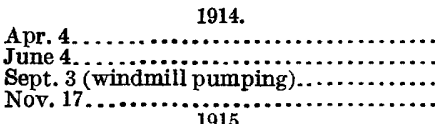 & \begin{tabular}{rr|} 
Ft. & in. \\
11 & 8 \\
10 & 2 \\
13 & 6 \\
12 & 5
\end{tabular} & 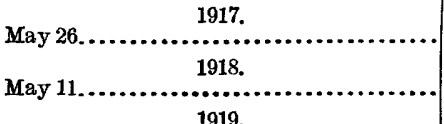 & $\begin{array}{rr}\text { Ft. } & \text { in. } \\
9 & 11 \\
11 & 2\end{array}$ \\
\hline 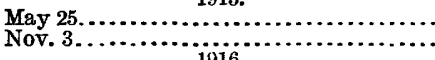 & $\begin{array}{rr}11 & 8 \\
11 & 11\end{array}$ & $\begin{array}{l}\text { May } 9 \ldots \ldots \ldots \ldots \ldots \ldots \ldots \ldots \ldots \\
\text { Nov. } 10 \ldots \ldots \ldots \ldots \ldots \ldots \ldots \ldots \ldots\end{array}$ & $\begin{array}{ll}11 & 0 \\
13 & 4\end{array}$ \\
\hline 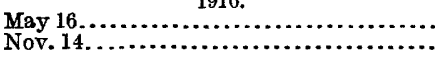 & $\begin{array}{ll}10 & 0 \\
10 & 6\end{array}$ & 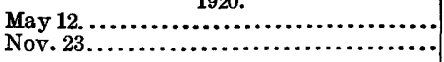 & $\begin{array}{lr}12 & 5 \\
13 & 11\end{array}$ \\
\hline
\end{tabular}


Records of water levels in the valley of southern California-Continued.

29. John MeCoy (formerly owned by J. A. Law), half a mile east of El Monte, Pasadena quadrangle.

[Bored well, 50 feet deep, 7 inches in diameter; altitude of surface,about 282 feet above sea level; method of lift, wind; use, domestic. Bench mark: Top of casing, 1 foot 9 inches above surface. Well No. 141, Water-Supply Páper 219, p. 164.]

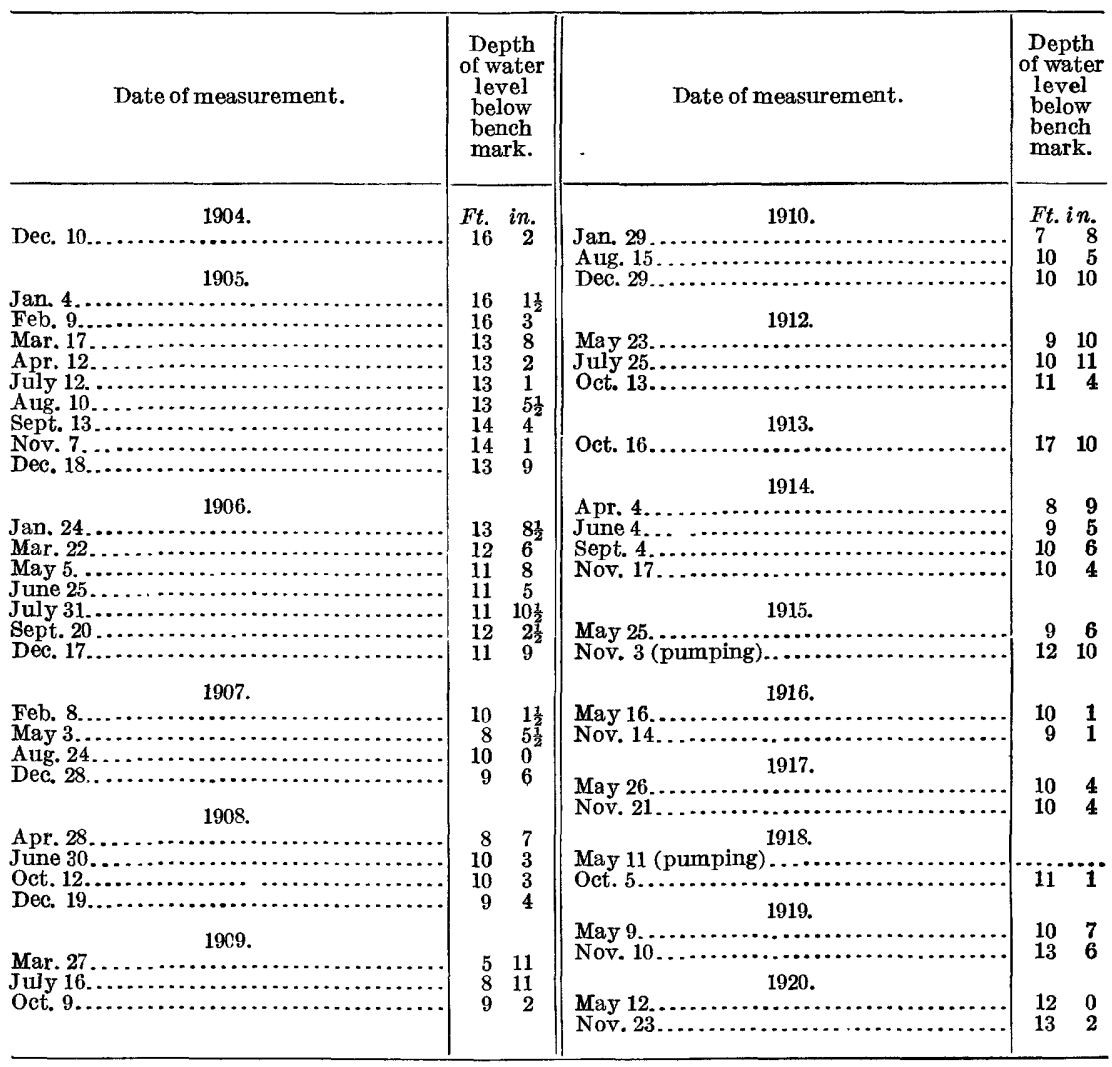

29a. Mr. Ward (formerly owned by Mr. Beck), half a mile east of El Monte, Pasadena quadrangle.

[Bored well, 7 inches in diameter; altitude of surface, about 275 feet above sea level; method of lift: wind; use, domestic. Bench mark: Top of casing, 1.0 foot above surface. Well No. 477, Water-Supply Paper 21:, p. 175. Has been measured in conjunction with observation wells but record not published heretofore.]

\begin{tabular}{|c|c|c|c|}
\hline Date of measurement. & $\begin{array}{l}\text { Depth } \\
\text { of water } \\
\text { level } \\
\text { below } \\
\text { bench } \\
\text { mark. }\end{array}$ & Date of measurement. & $\begin{array}{l}\text { Depth } \\
\text { of water } \\
\text { level } \\
\text { below } \\
\text { bench } \\
\text { mark. }\end{array}$ \\
\hline 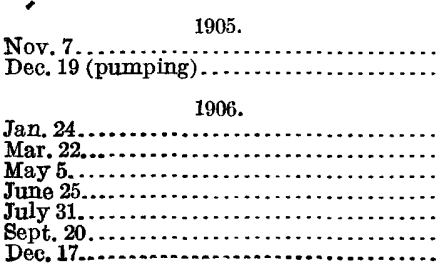 & $\begin{array}{ll}\text { Ft. } & \text { in. } \\
14 & 11 \\
15 & 5 \\
& \\
14 & 4 \\
14 & 9 \frac{1}{2} \\
13 & 7 \\
13 & 8 \frac{1}{2} \\
14 & 0 \\
14 & 2 \frac{1}{2} \\
13 & 1 \frac{1}{2}\end{array}$ & 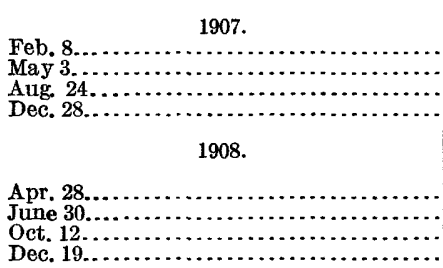 & $\begin{array}{rc}F t . & i n_{\text {. }} \\
11 & 10 \frac{1}{2} \\
9 & 11 \\
10 & 4 \\
10 & 7\end{array}$ \\
\hline
\end{tabular}


Records of water levels in the valley of southern California-Continued.

30a. County well, 1 mile southeast of El Monte, Pasadena quadrangle.

[Bored well, 30 feet deep, 7 inches in diameter; altitude of surface, about 284 feet above sea level; method of lift, wind; use, stock. Bench mark: Top of 1 -inch cover over casing, level with surface. Well No. 163, Water-Supply Paper 219, p. 165. Companion well for No. 30.]

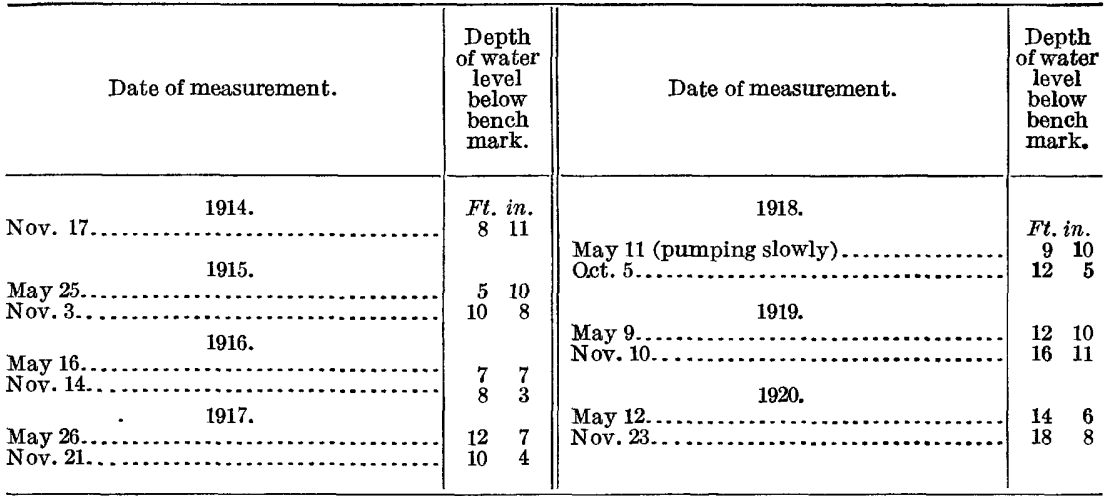

31. C. H. Clark (formerly owned by Mrs. McClure), three-fourths mile south of EI Monte, Pasadena quadrangle.

[Bored well, 61 feet deep, 7 inches in diameter; altitude of surface, about 265 feet above sea level; method of lift, wind; use, domestic. Bench mark: Top of casing, 1 foot 10 inches above surface. Well No. 479 , Water-Supply Paper 219, p. 175.]

\begin{tabular}{|c|c|c|c|}
\hline Date of measurement. & $\begin{array}{c}\text { Depth } \\
\text { of water } \\
\text { level } \\
\text { below } \\
\text { bench } \\
\text { mark. }\end{array}$ & Date of measurement. & $\begin{array}{c}\text { Depth } \\
\text { of water } \\
\text { level } \\
\text { below } \\
\text { bench } \\
\text { mark. }\end{array}$ \\
\hline 1905. & Ft, in. & 1912. & Ft. in. \\
\hline Jan. $4 . . . .$. & 166 & 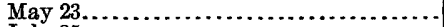 & 94 \\
\hline (n) & 1510 & July $25 \ldots \ldots \ldots \ldots \ldots \ldots \ldots$ & 11 \\
\hline $\begin{array}{l}\text { Mar. } 17 \ldots . . \\
\text { July } 12 . . .\end{array}$ & $\begin{array}{ll}14 & 2 \\
12 & 5\end{array}$ & Oct. $13 \ldots \ldots \ldots \ldots$ & 126 \\
\hline Aug. $10 \ldots$ & 139 & 1913. & \\
\hline $\begin{array}{l}\text { Sept. } 13 \ldots . \\
\text { Nov. } 7 . . .\end{array}$ & $\begin{array}{ll}14 & 8 \\
6\end{array}$ & Oct. $16 \ldots \ldots \ldots \ldots$ & 12 \\
\hline Dec. $18 . . .$. & $13 \quad 6$ & 10 & \\
\hline 1906. & & June $25 \ldots . . . . .$. & $\begin{array}{l}8 \\
9\end{array}$ \\
\hline $\operatorname{Jan} .24 \ldots .$. & $13 \quad 1$ & Sept. $4 \ldots . . .$. & 9 \\
\hline Mar. 22...... & 1210 & Nov. $17 . . . .$. & 9 \\
\hline $\begin{array}{l}\text { May } 5 \ldots \ldots \ldots \ldots \\
\text { June } 25\end{array}$ & $\begin{array}{ll}10 & 6 \\
10 & 0\end{array}$ & 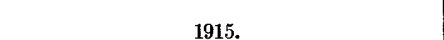 & \\
\hline July $31 \ldots . .$. & $10 \quad 4 \frac{1}{2}$ & May $25 . . . . .$. & 8 \\
\hline Sept. $20 \ldots$. & $12 \quad \frac{1}{2}$ & Nov. $3 . . . .$. & 9 \\
\hline Dec. $17 . . .$. & & 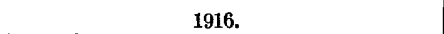 & \\
\hline Feb 8 & & May $16 \ldots \ldots \ldots \ldots \ldots$ & 9 \\
\hline May $3 \ldots \ldots \ldots$ & $\begin{array}{ll}8 & 1 \\
7 & 0 \\
8 & 6 \frac{1}{2}\end{array}$ & 1917. & 810 \\
\hline Dec. 28...... & 3 & (n) & $\begin{array}{r}9 \\
10\end{array}$ \\
\hline Apr. $28 \ldots \ldots \ldots$ & 8 & 1918. & \\
\hline June $30 \ldots \ldots . .$. & 2 & 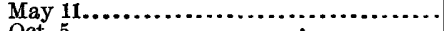 & 10 \\
\hline Dec. $19 \ldots \ldots \ldots$ & 94 & 1919. & 10 \\
\hline $\begin{array}{c}1909 . \\
\text { Mar. } 27 \ldots \ldots \ldots \ldots \ldots \ldots \ldots \ldots \ldots \ldots \ldots \ldots \ldots \ldots \ldots \ldots \ldots\end{array}$ & 6 & $\begin{array}{l}\text { May }{ }_{1}{ }_{1} \\
\text { Nov } 10, \ldots\end{array}$ & $\begin{array}{rr}10 & 11 \\
13 & 3\end{array}$ \\
\hline Oct. $9 . \ldots \ldots \ldots$. & 88 & May 12 & 12 \\
\hline 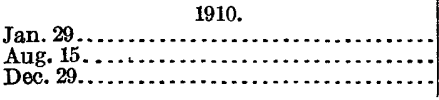 & $\begin{array}{rr}7 & 6 \\
10 & 4 \\
10 & 6\end{array}$ & Nov. 23. & 13 \\
\hline
\end{tabular}


Records of water levels in the valley of southern California-Continued.

31a. C. H. Clark, three-fourths mile south of El Monte, Pasadena quadrangle.

[Bench mark, bottom of 12 by 12 timber across curb, level with ground, marked with white paint. Companion well for No. 31, 175 feet northwest of No. 31. Engine and pump house.]

\begin{tabular}{|c|c|c|c|}
\hline Date of measurement. & $\begin{array}{l}\text { Depth } \\
\text { of water } \\
\text { level } \\
\text { below } \\
\text { bench } \\
\text { mark. }\end{array}$ & Date of measurement. & $\begin{array}{l}\text { Depth } \\
\text { of water } \\
\text { level } \\
\text { below } \\
\text { bench } \\
\text { mark. }\end{array}$ \\
\hline 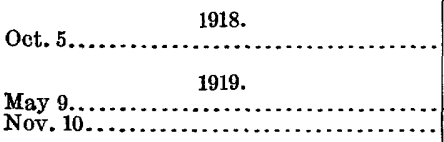 & $\begin{array}{rr}\text { Ft. in. } \\
8 & 6 \\
& \\
8 & 10 \\
11 & 4\end{array}$ & 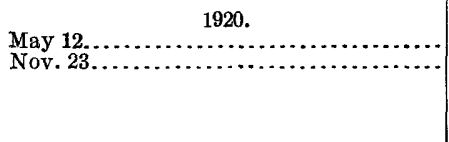 & $\begin{array}{l}\text { Ft. in. } \\
10 \text {. } \\
11 \text { 11 }\end{array}$ \\
\hline
\end{tabular}

32. L. Bergstrom (formerly owned by T. D. Andrews), $1 \frac{1}{2}$ miles southeast of El Monte, Pasadena quadrangle.

[Bored well, 25 feet deep, 7 inches in diameter; altitude of surface, about 275 feet above sea level; method of lift, hand pump; use, domestic. Bench mark: Top of 2 -inch cover over casing, 2 feet 5 inches above surface. Well No. 164, Water-Supply Paper 219, p. 165.]

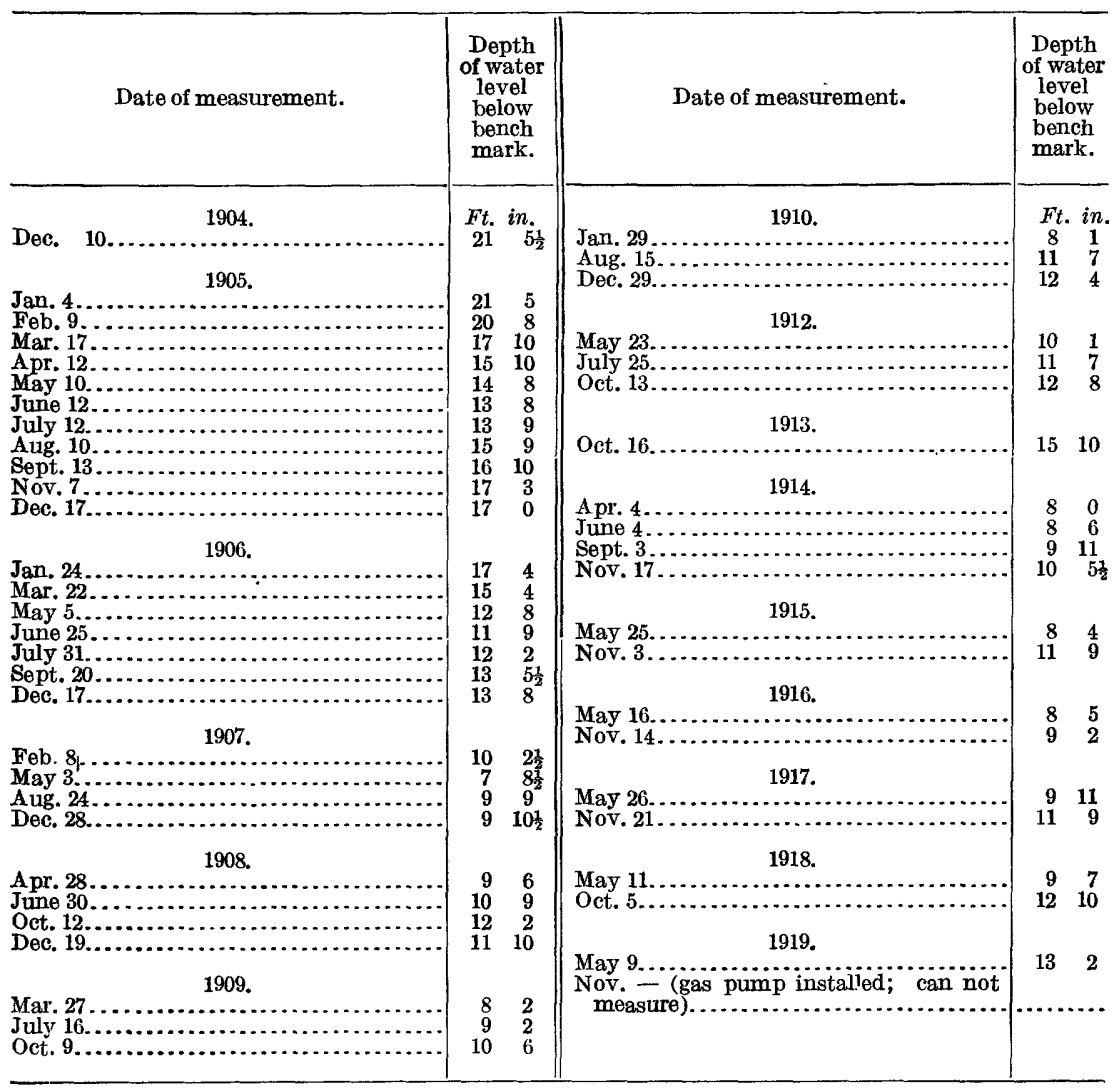


Records of water levels in the valley of southern California-Continued.

33. Jackson Freer, 2 miles southeast of El Monte, Pasadena quadrangle.

[Bored well, 7 inches in diameter; altitude of surface, about 290 feet above sea level; method of lift, wind; use, domestic. Bench mark not known. Well No. 173, Water-Supply Paper 219, p. 165.]

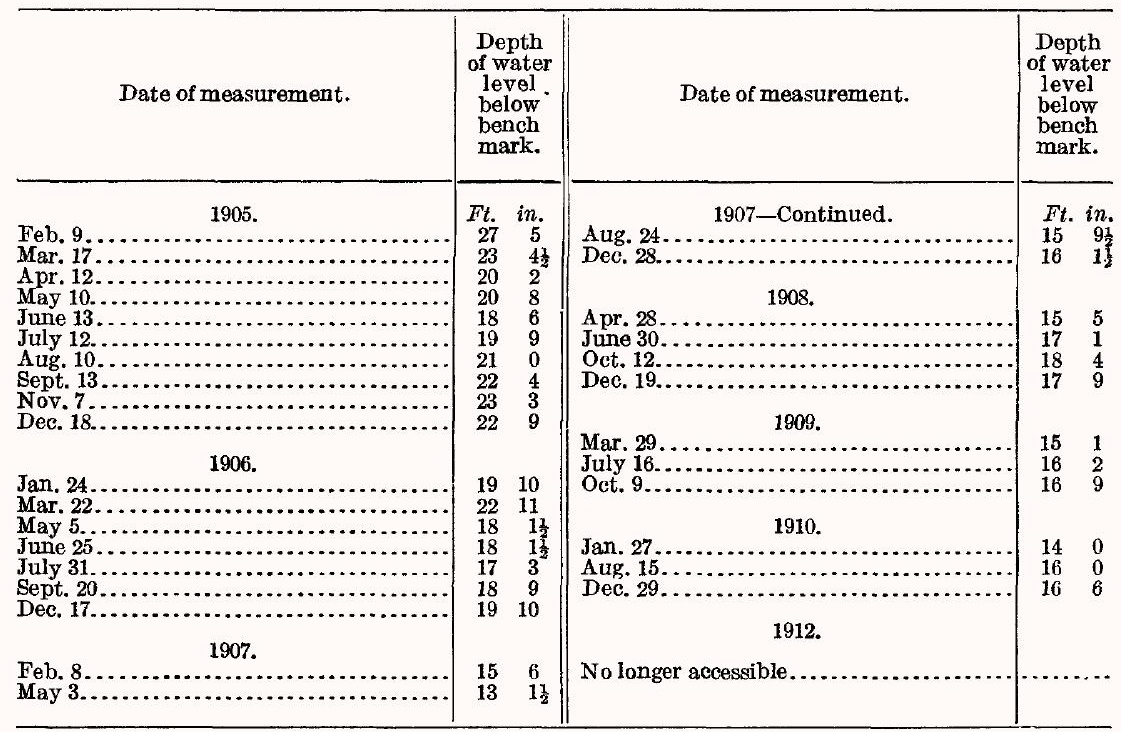

33a. Jackson Freer, 2 miles southeast of El Monte, Pasadena quadrangle.

[Bored well, 7 inches in diameter. Situated 200 feet southwest of No. 33. Small gasoline pumping plant. Bench mark: Top of casing, 3 inches above surface.]

\begin{tabular}{|c|c|c|c|}
\hline Date of measurement. & $\begin{array}{l}\text { Depth } \\
\text { of water } \\
\text { level } \\
\text { below } \\
\text { bench } \\
\text { mark. }\end{array}$ & Date of measurement. & $\begin{array}{l}\text { Depth } \\
\text { of water } \\
\text { level } \\
\text { below } \\
\text { bench } \\
\text { mark. }\end{array}$ \\
\hline 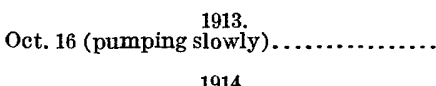 & $\begin{array}{rr}\text { Et. } & \text { in. } \\
20 & 1\end{array}$ & 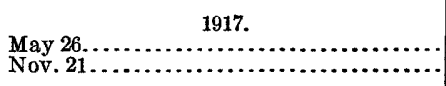 & $\begin{array}{ll}F t . & \text { in } \\
13 & 11 \\
15 & 10\end{array}$ \\
\hline 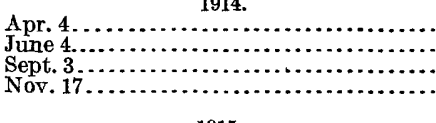 & $\begin{array}{rr}11 & 10 \\
12 & 1 \\
14 & 0 \\
14 & 3\end{array}$ & 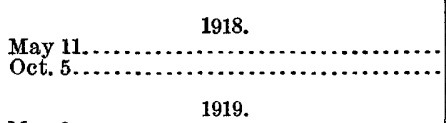 & 14 \\
\hline 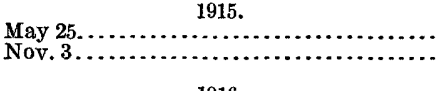 & $\begin{array}{ll}11 & 4 \\
14 & 6\end{array}$ & 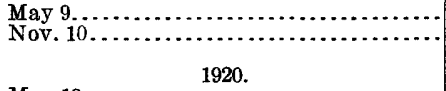 & $\begin{array}{ll}15 & 5 \\
21 & 6\end{array}$ \\
\hline 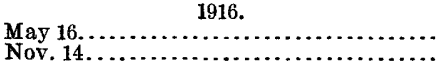 & $\begin{array}{ll}11 & 8 \\
12 & 8\end{array}$ & $\begin{array}{l}\text { May } 12, \ldots \ldots \ldots \ldots \ldots \\
\text { Nov, } 23 \ldots \ldots \ldots \ldots\end{array}$ & $\begin{array}{rr}18 & 11 \\
22 & 3\end{array}$ \\
\hline
\end{tabular}


Records of water levels in the valley of southern California-Continued.

33b. A. Elliot, half a mile southwest of well No. 33a, Pasadena quadrangle.

[Well bored 45 feet deep, 6 inches in diameter; method of lift, wind; use, domestic. Ccmpanion well for Nos. 32 and 33a. Bench mark: Top of easing, 1 foot 4 inches above surface.]

\begin{tabular}{|c|c|c|c|}
\hline Date of measurement. & $\begin{array}{l}\text { Depth } \\
\text { of water } \\
\text { level } \\
\text { below } \\
\text { bench } \\
\text { mark. }\end{array}$ & Date of measurement. & $\begin{array}{l}\text { Depth } \\
\text { of water } \\
\text { level } \\
\text { below } \\
\text { bench } \\
\text { mark. }\end{array}$ \\
\hline 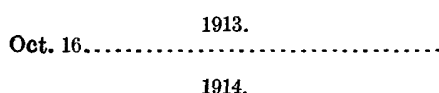 & $\begin{array}{rr}\text { Ft. } & \text { in. } \\
12 & 7\end{array}$ & 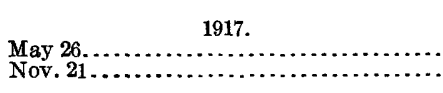 & $\begin{array}{lr}F t . & \text { in } \\
11 & 0 \\
10 & 11\end{array}$ \\
\hline 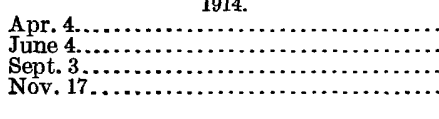 & $\begin{array}{rr}8 & 10 \\
9 & 1 \\
10 & 0 \\
9 & 11\end{array}$ & 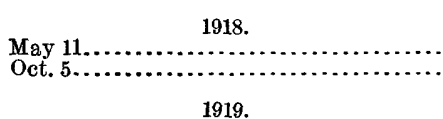 & $\begin{array}{r}9 \\
12\end{array}$ \\
\hline $\begin{array}{l}\text { May } 28 \ldots \ldots \ldots \ldots \ldots \ldots \ldots \ldots \ldots \ldots \ldots \ldots \ldots \\
\text { Nov. } 3 \ldots \ldots \ldots \ldots \ldots \ldots \ldots \ldots \ldots \ldots \ldots \ldots \ldots\end{array}$ & $\begin{array}{rr}8 & 7 \\
11 & 4\end{array}$ & 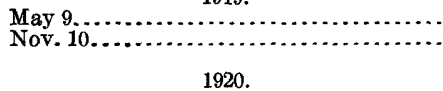 & $\begin{array}{ll}11 & 7 \\
14 & 6\end{array}$ \\
\hline 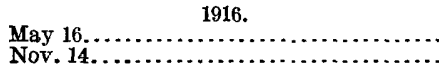 & $\begin{array}{rr}9 & 11 \\
9 & 0\end{array}$ & $\begin{array}{l}\text { May } 12, \ldots \ldots \ldots \ldots \\
\text { Nov, } 23 \ldots \ldots \ldots \ldots \ldots \ldots \ldots\end{array}$ & $\begin{array}{l}13 \\
15\end{array}$ \\
\hline
\end{tabular}

34. E. Gurado, 3 miles southwest of Whittier, Downey quadrangle.

[Bored well, 41 feet deep, 7 inches in diameter; altitude of surface, about 180 feet above sea level; method of lift, wind: use, domestic. Water contains 260 parts per million of dissolved solids. Bench mark not known. Well No. 2867, Water-Supply Paper 138, p. 143.]

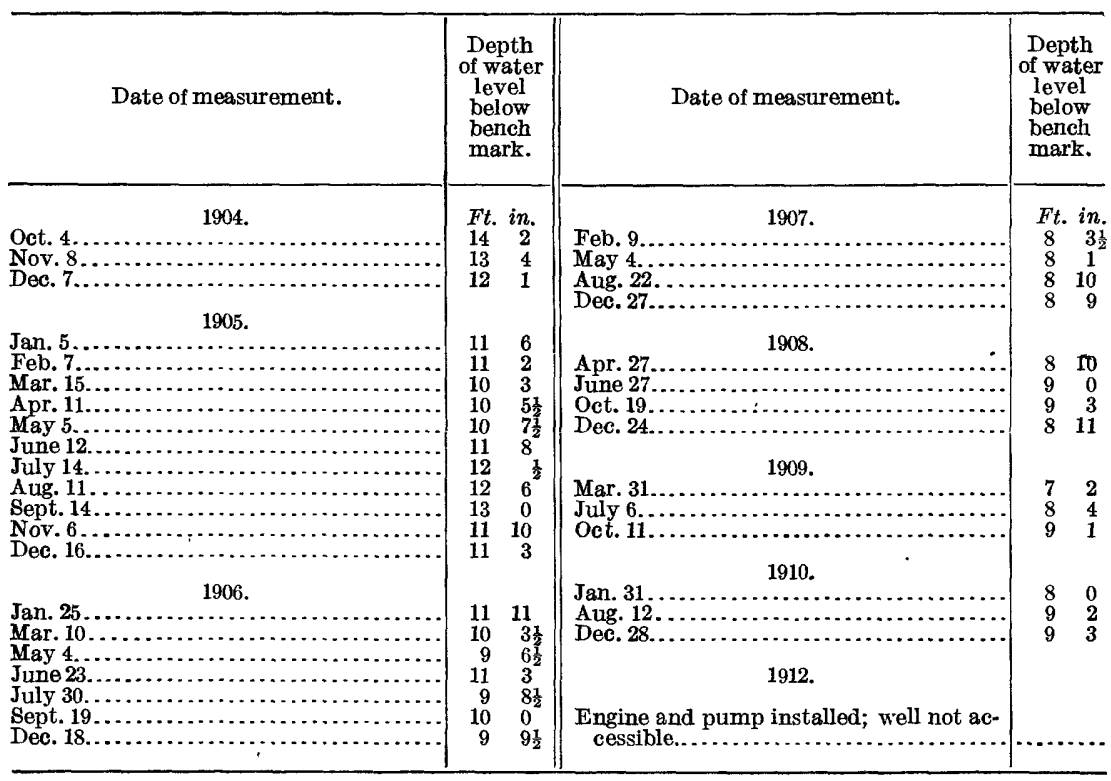


Records of water levels in the valley of southern California-Continued.

35. Mrs. Mary Theland, 2 miles southwest of Whittier, Downey quadrangle.

[Bored well, 72 feet deep, 4 inches in diameter; sunk about 1874; altitude of surface, about 157 feet above sea level; method of lift, wind; water contains 390 parts per million of dissolved solids. Bench mark not known. Well No. 2902, Water-Supply Paper 138, p. 145.]

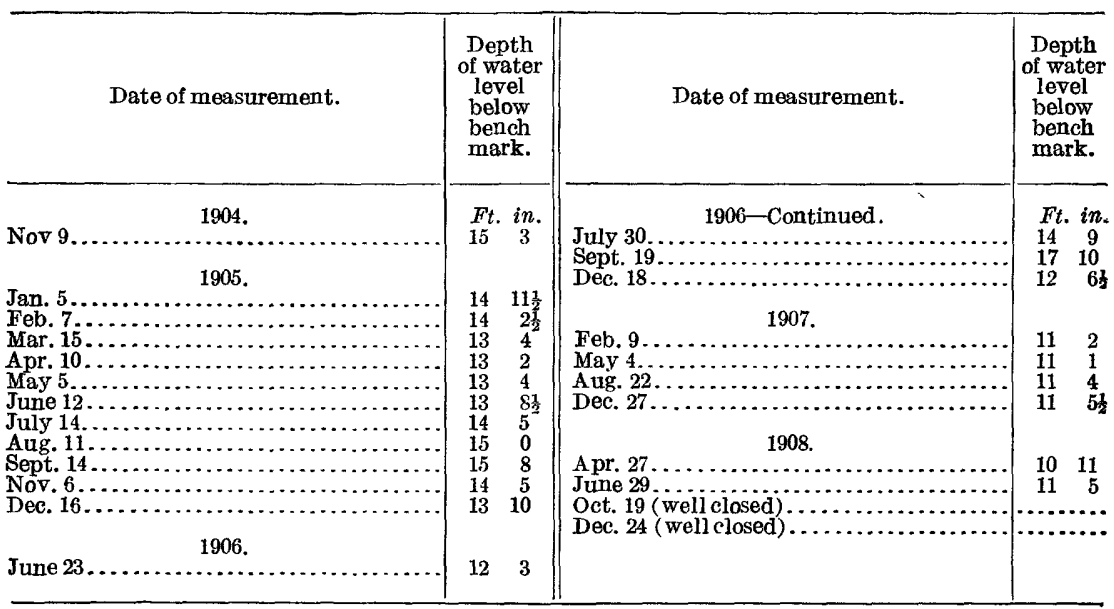

36. J. C. Buckmaster (formerly owned by H. C. Baldwin), half a mile southeast of Whittier, Downe quadrangle.

[Bench mark not known.]

\begin{tabular}{|c|c|c|c|}
\hline Date of measurement. & $\begin{array}{l}\text { Depth } \\
\text { of wcter } \\
\text { level } \\
\text { below } \\
\text { bench } \\
\text { mark. }\end{array}$ & Date of measurement. & $\begin{array}{l}\text { Depth } \\
\text { of water } \\
\text { level } \\
\text { below } \\
\text { bench } \\
\text { mark. }\end{array}$ \\
\hline 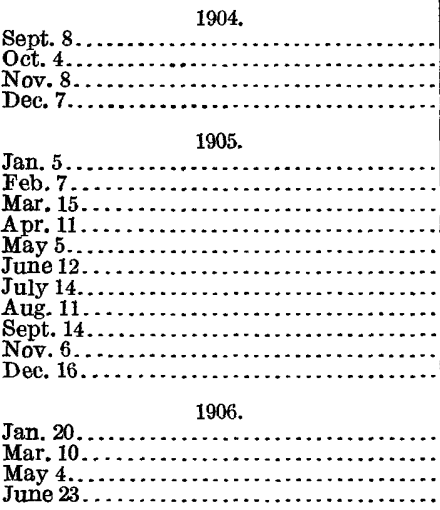 & $\begin{array}{cc}F t . & \text { in. } \\
129 & 2 \\
128 & 4 \frac{1}{2} \\
128 & 5 \\
128 & 7 \frac{1}{2} \\
& \\
& \\
128 & 6 \\
128 & 7 \\
128 & 8 \\
128 & 4 \\
128 & 3 \\
128 & 4 \frac{1}{2} \\
128 & 8 \\
128 & 10 \\
128 & 11 \\
129 & 0 \\
128 & 10\end{array}$ & 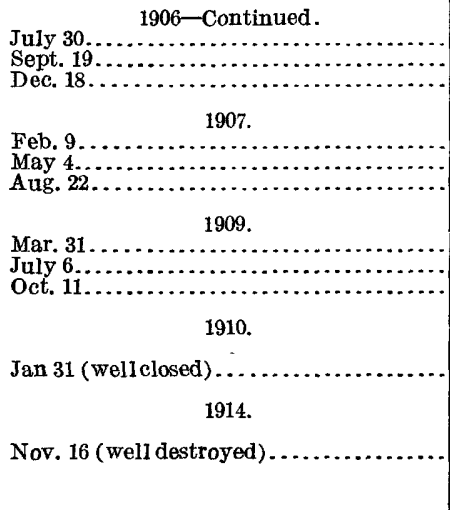 & $\begin{array}{cc}F t \text {. } & \text { in. } \\
128 & 6 \\
128 & 6 \frac{1}{2} \\
128 & 6 \\
& \\
& \\
127 & 103 \\
127 & 4 \\
127 & 7 \\
& \\
& \\
64 & 0 \\
63 & 0 \\
63 & 0\end{array}$ \\
\hline
\end{tabular}


Records of water levels in the valley of southern California-Continued.

37. R. A. Wallace (formerly owned by C. A. Landreth), 1 mile south of Whittier, Downey quadrangle.

[Bored well, 78 feet deep, 4 inches in diameter; sunk in 1901; altitude of surface, about 191 feet above sea level; method of lift, hand pump; use, domestic and stock. Water contains 1,020 varts per million of dissolved solids. Bench mark: Top of hand pump base, 2 feet above surface. Well No. 2979, Water Supply Paper 138, p. 147.]

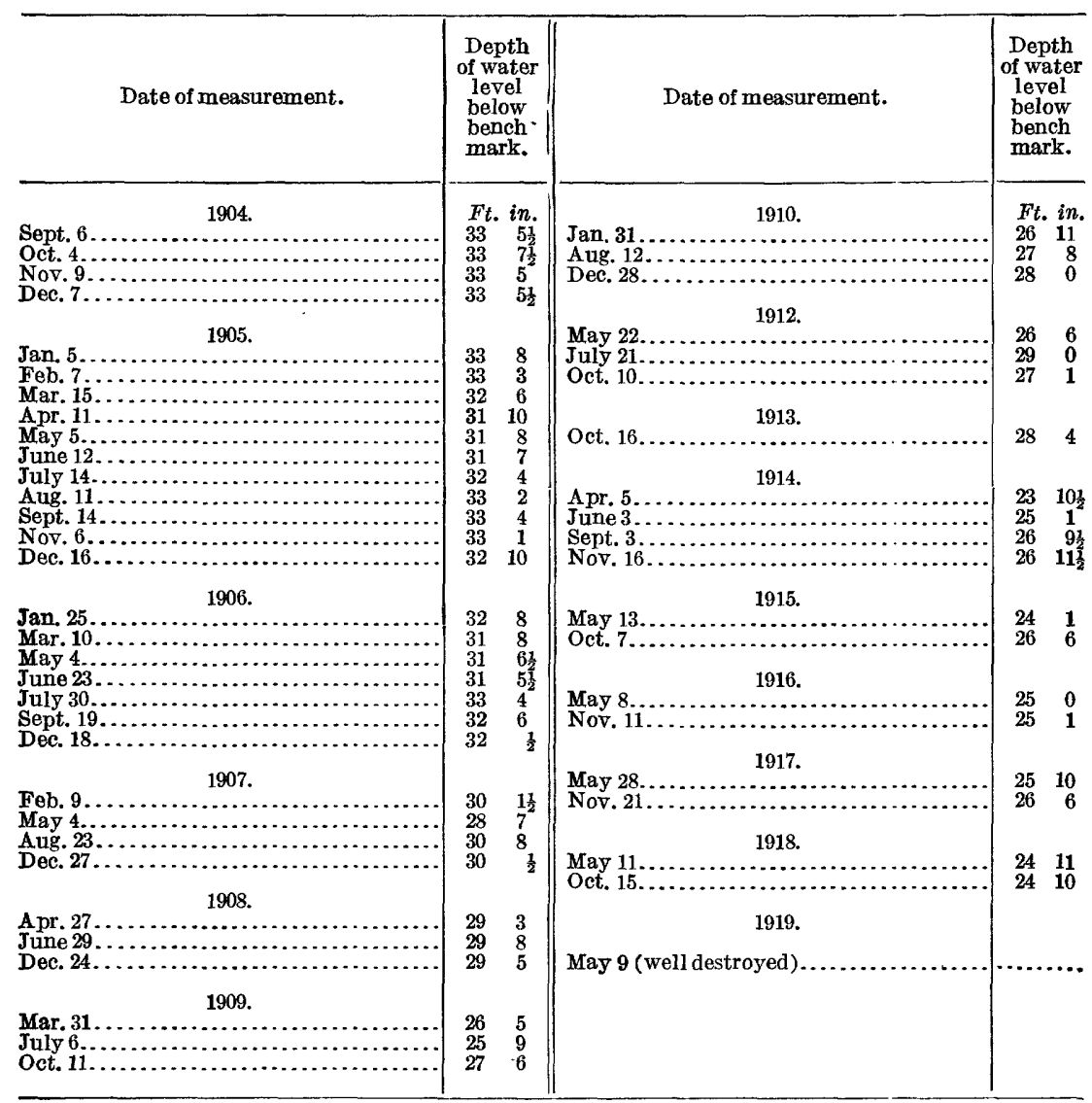


Records of water levels in the valley of southern California-Continued.

38. L. A. Brunson (formerly owned by J. W. Sharp), Santa Fe Springs, Downey quadrangle.

[Bored well, 380 feet deep, 7 inches in diameter; sunk about 1877; altitude of surface, about 150 feet above sea level; water not used. Bench mark: Top of 8 by 8 timber over well curb, 10 inches above surface. Well No. 2099, Water-Supply Paper 138, p. 117.]

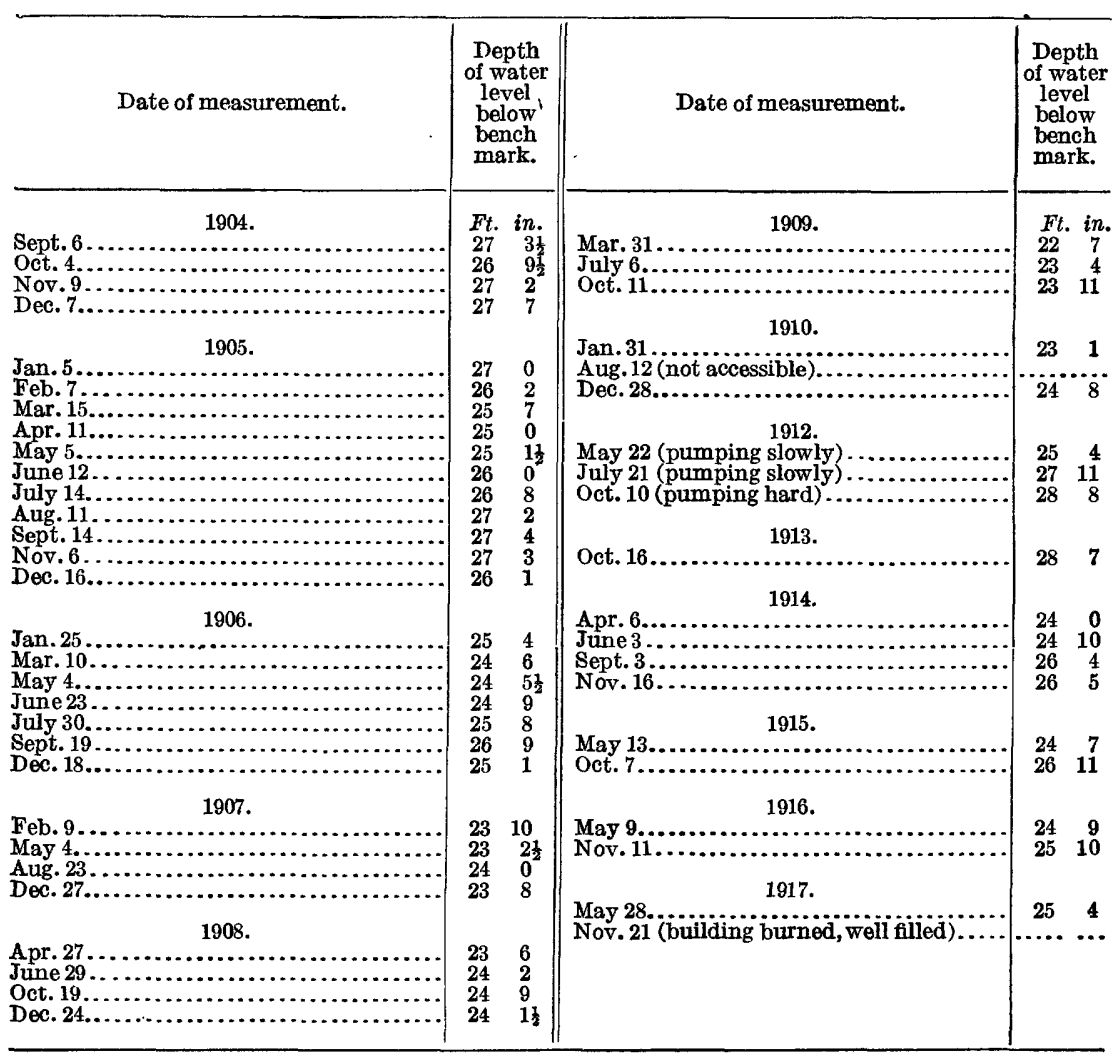

38a. W. H. Kuntz, Santa Fe Springs, Downey quadrangle.

[Companion well for No. 38; 7-inch casing, method of lift, wind; use, domestic; situated about 300 feet northeast of No. 38. Bench mark: Top of casing, 5 inches above surface.]

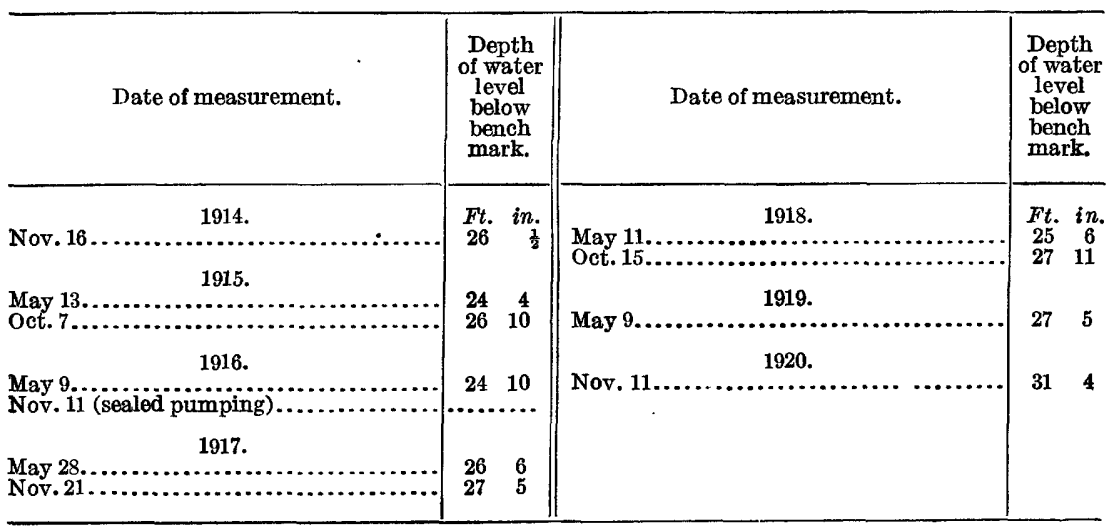


Records of water levels in the valley of southern California-Continued.

39. John H. Borden, $1 \frac{1}{2}$ miles north of Norwalk, Downey quadrangle.

[Bored well, 38 feet deep, 5 inches in diameter; sunk in 1903; altitude of surface, about 125 feet above sea level; bench mark not known. Well No. 2112, Water-Supply Paper 138, p. 117.]

\begin{tabular}{|c|c|c|c|}
\hline Date of measurement. & $\begin{array}{c}\text { Depth } \\
\text { of water } \\
\text { level } \\
\text { below } \\
\text { bench } \\
\text { mark. }\end{array}$ & Date of measurement. & $\begin{array}{l}\text { Depth } \\
\text { of water } \\
\text { level } \\
\text { below } \\
\text { bench } \\
\text { mark. }\end{array}$ \\
\hline 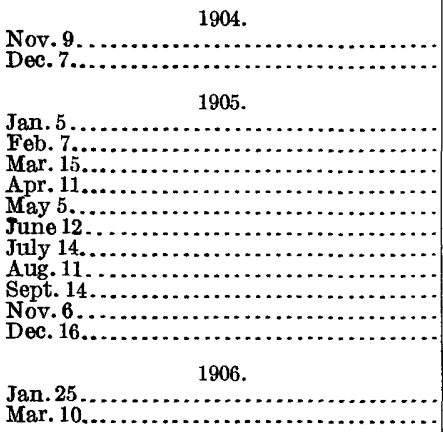 & $\begin{array}{rc}\text { Ft. } & \text { in. } \\
7 & 10 \\
8 & 5 \\
& \\
& \\
7 & 11 \\
6 & 10 \\
5 & 10 \frac{1}{2} \\
5 & 4 \\
5 & 1 \\
6 & 6 \\
7 & 2 \\
8 & 0 \\
8 & 8 \\
8 & 7 \\
7 & 1\end{array}$ & 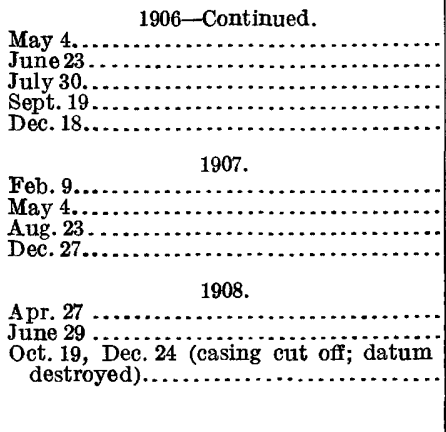 & $\begin{array}{rr}F t . & i n . \\
4 & 10 \frac{1}{2} \\
5 & 6 \frac{1}{2} \\
7 & 3 \frac{1}{2} \\
6 & 9 \frac{1}{2} \\
5 & 10 \\
& \\
& \\
4 & 31 \\
3 & 6 \frac{1}{2} \\
4 & 1 \frac{1}{2} \\
3 & 2 \frac{1}{2} \\
& \\
& \\
1 & 6 \\
5 & 1 \\
\ldots & \end{array}$ \\
\hline
\end{tabular}

40. Norwalk Builders Association, Norwalk, Downey quadrangle.

[Bored well, 97 feet deep, 7 inches in diameter; sunk in 1893; altitude of surface, about 100 feet above sea level; method of lift, wind; use, domestic. Water contains 510 parts per million of dissolved solids. Bench mark: Top of casing, 1 foot 2 inches above surface. Well No. 2125, Water-Supply Paper 138, p. 117.]

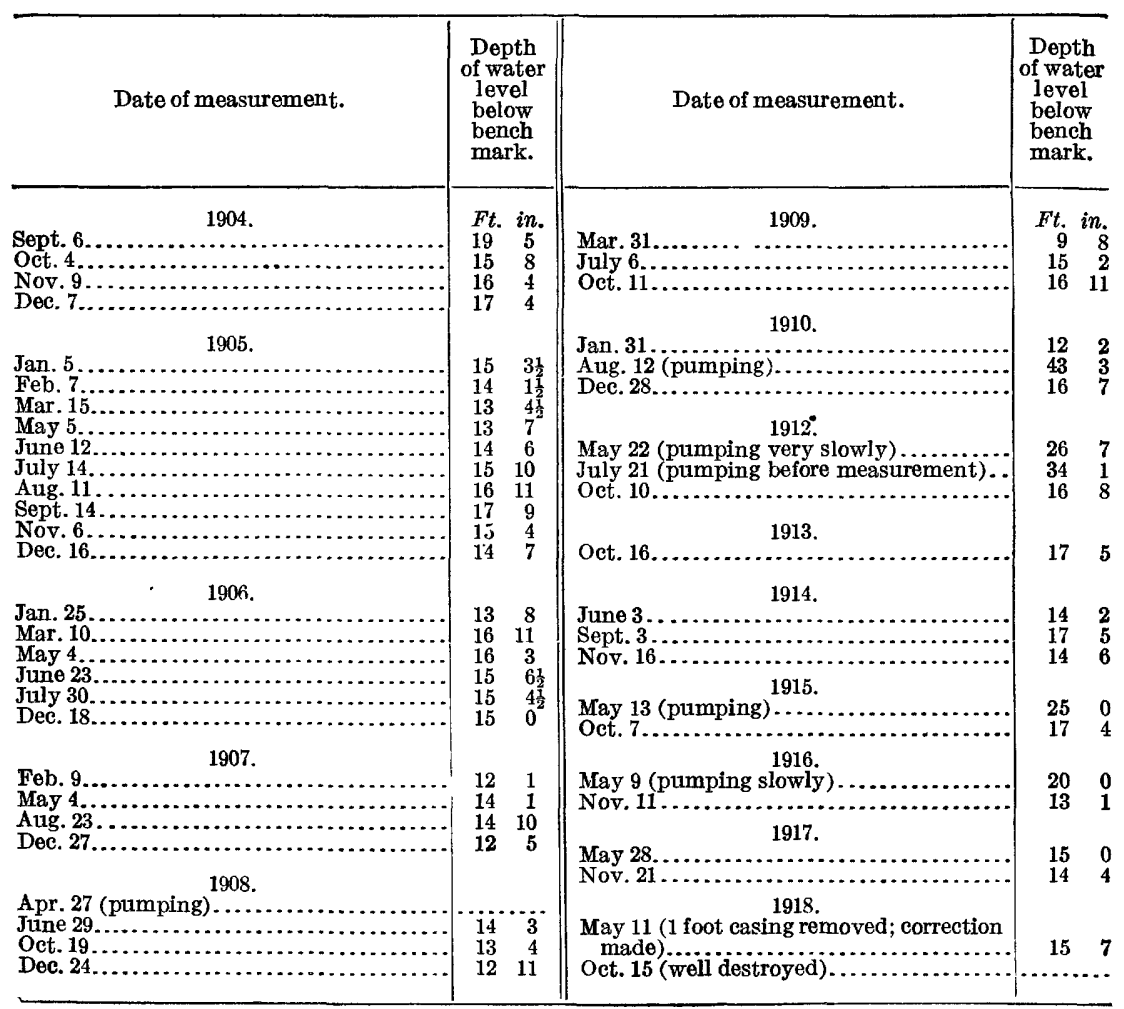


Records of water levels in the valley of southern California-Continued.

40a. Bank of Norwalk, Norwalk, Downey quadrangle.

[Companion well for No. 40. Four-inch casing; method of lift, wind; use, domestic; situated 50 feet southeast of No. 40. Bench mark: Top of casing, 1 foot 5 inches above surface.]

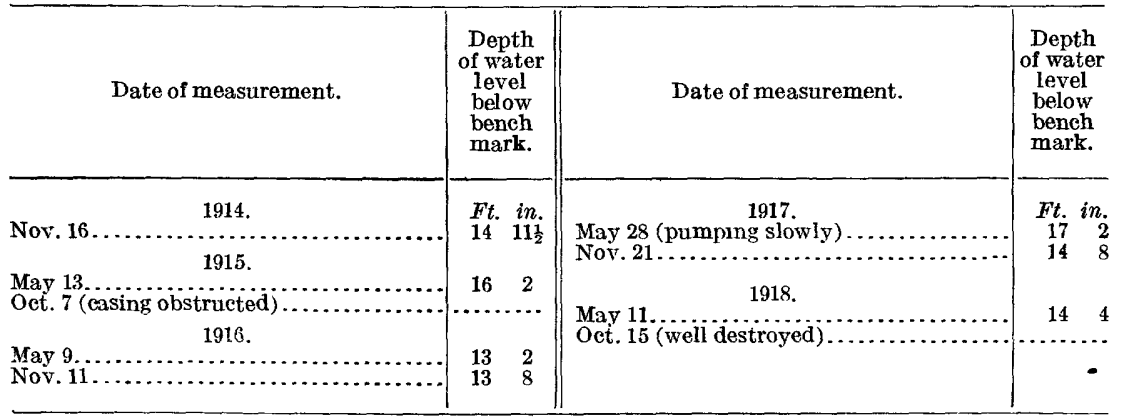

40b. G. B. Banta, Norwalk (Rose Lawn), Downey quadrangle.

[Bench mark: Top of casing, 6 inches above surface of ground. Companion well to No. 40a; selected Oct. 15, 1918; formerly flowed; 397 feet deep; 20 feet of 4-inch casing, remainder 2 -inch.]

\begin{tabular}{|c|c|c|c|}
\hline Date of measurement. & $\begin{array}{l}\text { Depth } \\
\text { of water } \\
\text { level } \\
\text { below } \\
\text { bench } \\
\text { mark. }\end{array}$ & Date of measurement. & $\begin{array}{l}\text { Depth } \\
\text { of water } \\
\text { level } \\
\text { below } \\
\text { bench } \\
\text { mark. }\end{array}$ \\
\hline 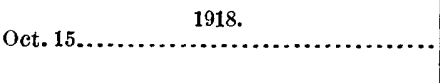 & ${ }_{8}{ }_{8}$ in & 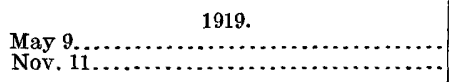 & $\begin{array}{rr}\text { Ft. } & \text { in. } \\
10 & 10 \\
12 & 2\end{array}$ \\
\hline
\end{tabular}

41. J. B. Neff, $1 \frac{1}{2}$ miles south of Anaheim, Anaheim qnadrangle.

[Bench mark: Top of curb, 50 feet 4 inches above top of casing. Records furnished by owner.]

\begin{tabular}{|c|c|c|c|}
\hline Date of measurement. & $\begin{array}{l}\text { Depth } \\
\text { of water } \\
\text { level } \\
\text { below } \\
\text { bench } \\
\text { mark. }\end{array}$ & Date of measurement. & $\begin{array}{l}\text { Depth } \\
\text { of water } \\
\text { level } \\
\text { below } \\
\text { bench } \\
\text { mark. }\end{array}$ \\
\hline 1898. & Ft. in. & 1899-Continued. & Ft, in. \\
\hline Feb. $22 \ldots \ldots \ldots \ldots \ldots \ldots$ & 234 & July $30 \ldots \ldots \ldots$ & 335 \\
\hline May $26 \ldots . . . . . .$. & 250 & Aug. $14, \ldots \ldots$ & 34 \\
\hline June $20 . \ldots . . .1$. & 2510 & Aug. 20 ............ & 34 \\
\hline July 1 . & 262 & Sept. 1 . & 34 \\
\hline 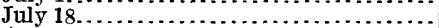 & 2610 & Sept. 13 & 34 \\
\hline Aug. 18 . . & $27 \quad 0$ & Oct. $2 \ldots \ldots$ & 34 \\
\hline Sept. 1 & 27 & (n) & 35 \\
\hline Sept. $10 \ldots \ldots \ldots \ldots$ & 27 & Nov. $30 \ldots . .$. & 35 \\
\hline 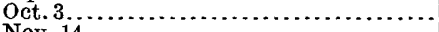 & 280 & Dec. $28 \ldots \ldots \ldots$ & $35 \quad 10$ \\
\hline $\begin{array}{l}\text { Nov. } 14, \ldots \ldots \ldots \\
\text { Nov. } 30 \ldots \ldots \ldots\end{array}$ & $\begin{array}{ll}28 & 7 \\
28 & 9\end{array}$ & 1900. & \\
\hline Dec. $15, \ldots \ldots \ldots \ldots \ldots \ldots \ldots \ldots$ & $29 \quad 2$ & Jan. $11 \ldots$ & 36 \\
\hline 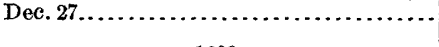 & $29 \quad 6$ & $\begin{array}{l}\text { Jan } 30 \ldots \ldots \ldots \ldots \ldots \ldots \ldots \ldots \ldots \ldots \ldots \\
\text { Feb. } 26, \ldots \ldots \ldots \ldots \ldots\end{array}$ & $\begin{array}{l}36 \\
36\end{array}$ \\
\hline Jan. 14 & & $\ldots \ldots \ldots$. & $\begin{array}{l}37 \\
38\end{array}$ \\
\hline Feb. $7 \ldots$ & 0 & May $29 .$. & $\begin{array}{l}38 \\
38\end{array}$ \\
\hline Mar & 30 & 1030. & 39 \\
\hline Mar. 31... & 31 & July $31 \ldots \ldots \ldots \ldots \ldots \ldots \ldots$ & 39 \\
\hline Apr. 27... & 31 & Aug. $31 \ldots \ldots \ldots \ldots \ldots \ldots \ldots \ldots \ldots$ & 40 \\
\hline May $13 . . . .$. & 11 & Oct. $4 \ldots .$. & 40 \\
\hline May $29 . . .$. & 32 & Nov, $4 \ldots$ & 41 \\
\hline June $28 \ldots$. & 3211 & V. $27 \ldots$ & 41 \\
\hline July $20 . \ldots$. & 335 & c. 12 . & 41 \\
\hline
\end{tabular}


Records of water levels in the valley of southern California-Continued.

41. J. B. Neff-Continued.

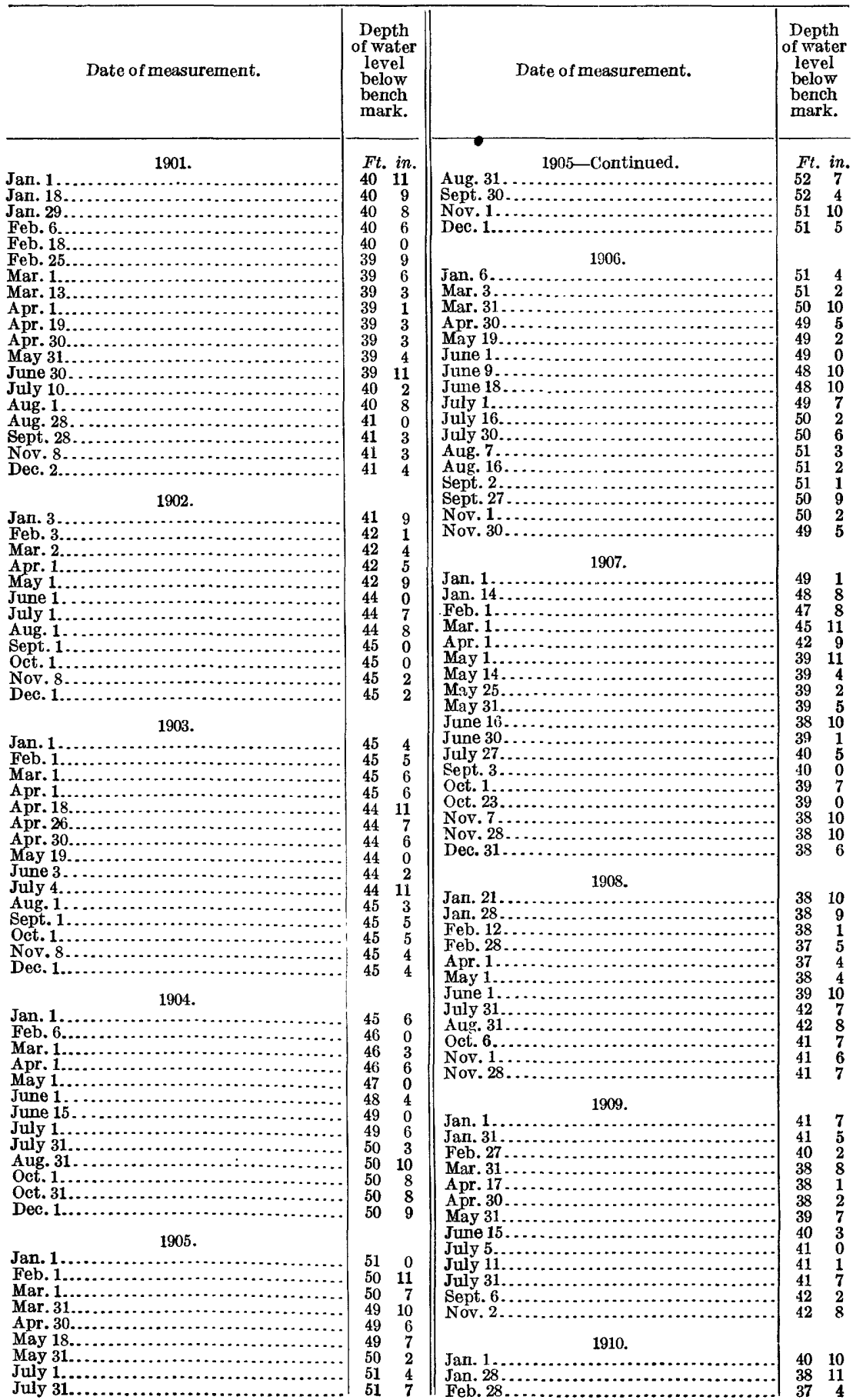


Records of water levels in the valley of southern California--Continued.

41. J. B. Neff-Continued.

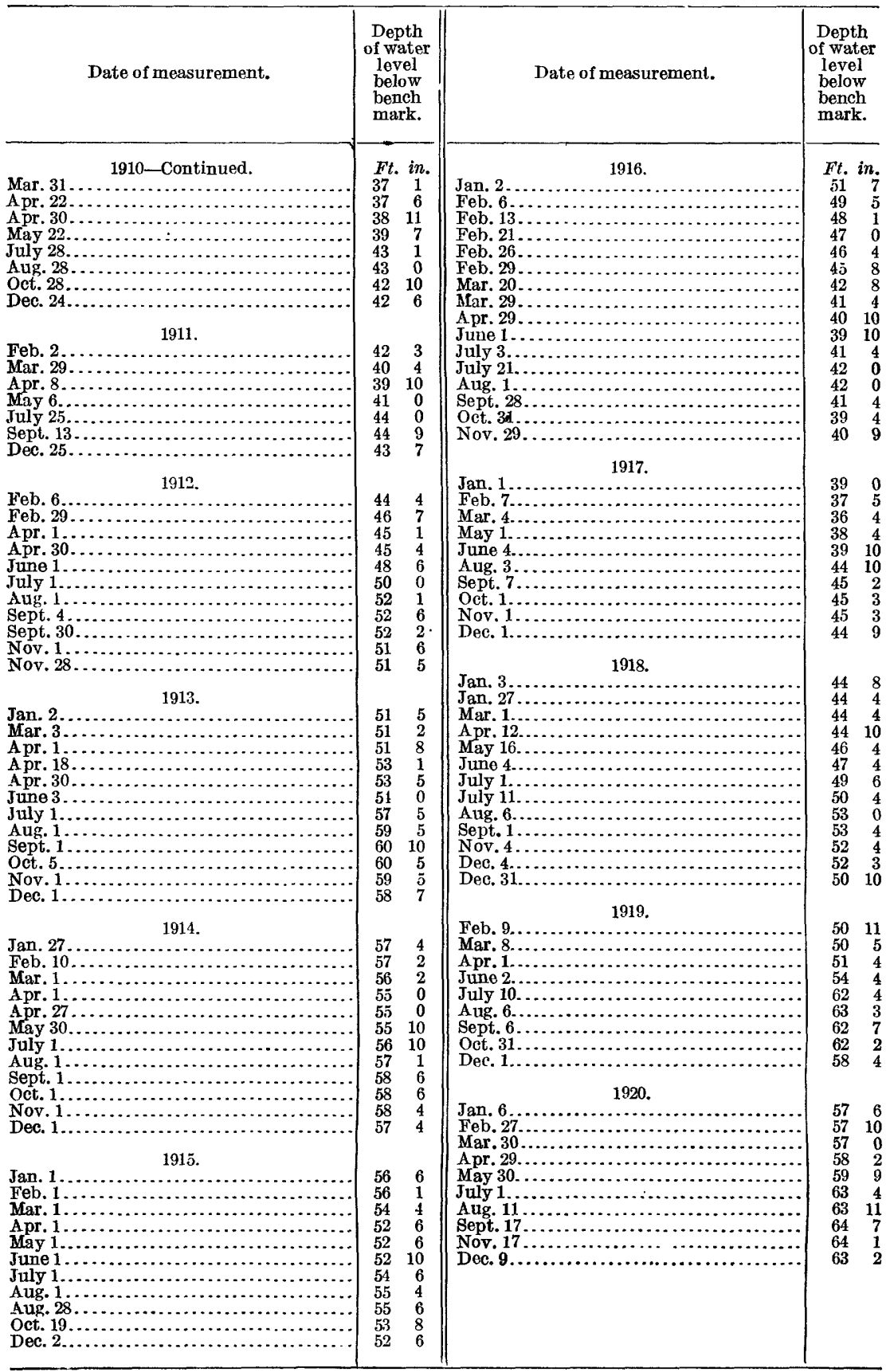


Records of water levels in the valley of southern California-Continued.

42. Abandoned school, Baldwin Park (formerly called Vineland), Pomona quadrangle.

[Bored well, 140 feet deep, 7 inches in diameter; altitude of surface, about 382 feet above sea level; method of lift, wind; use, domestic. Water contains 270 parts per million of dissolved solids. Bench mark: Top of casing, 4 feet 1 inch above surface. Well No. 87, Water-Supply Paper 219, p. 155.]

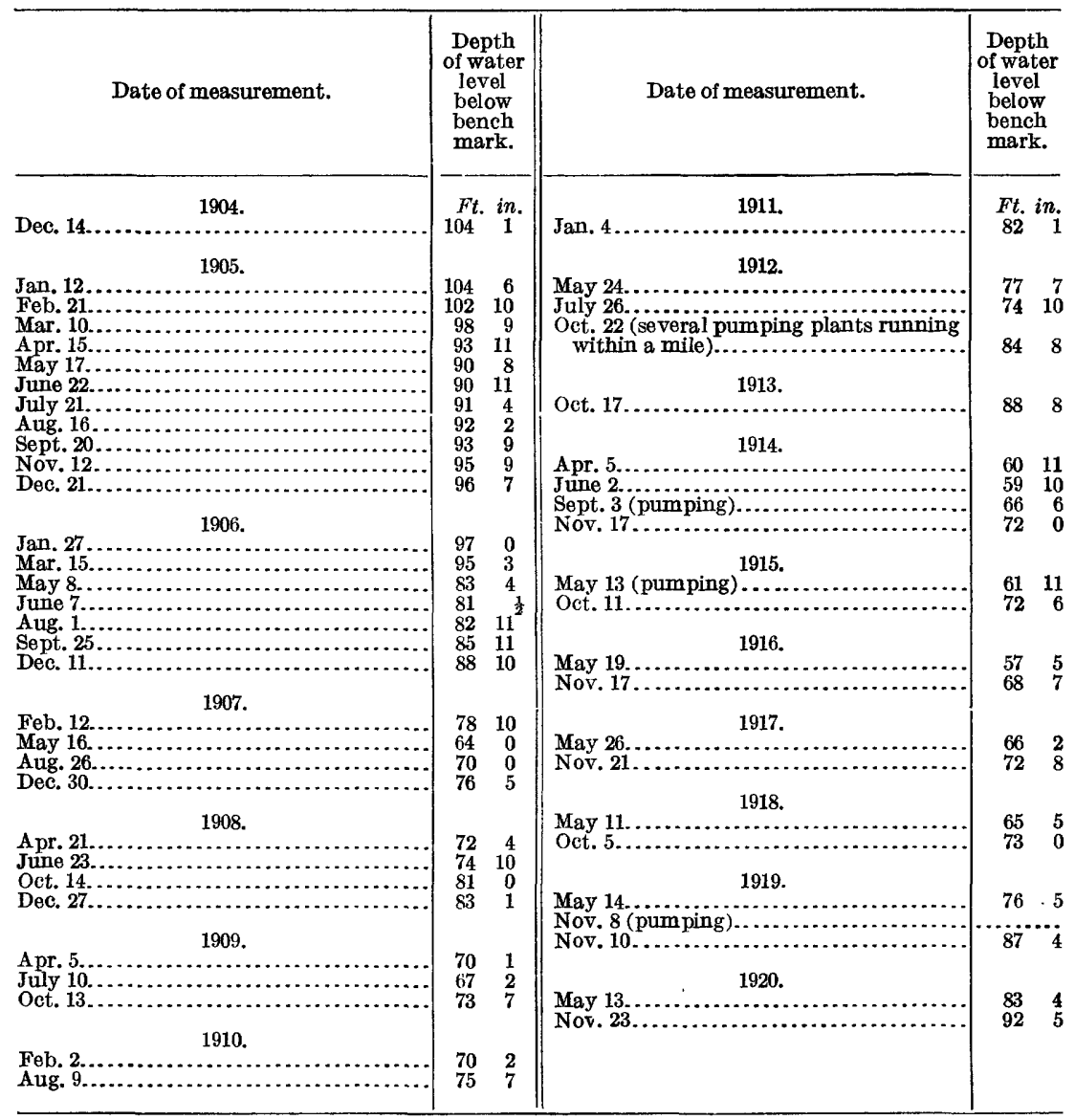


Records of water levels in the valley of southern California-Continued.

43. G. F. Chamberlain, 2 miles southwest of Covina, Pomona quadrangle.

[Dug well, 118 feet deep 3 by 3 feet in cross section; sunk in 1900; altitude of surface, about 422 feet above sea level; method of lift, wind; use, domestic. Water contains 220 parts per million of dissolved solids. Bench mark: Top of 2-inch cover over casing, 1 foot 5 inches above surface. Well No. 96, Water-Supply Paper 219, p. 155.]

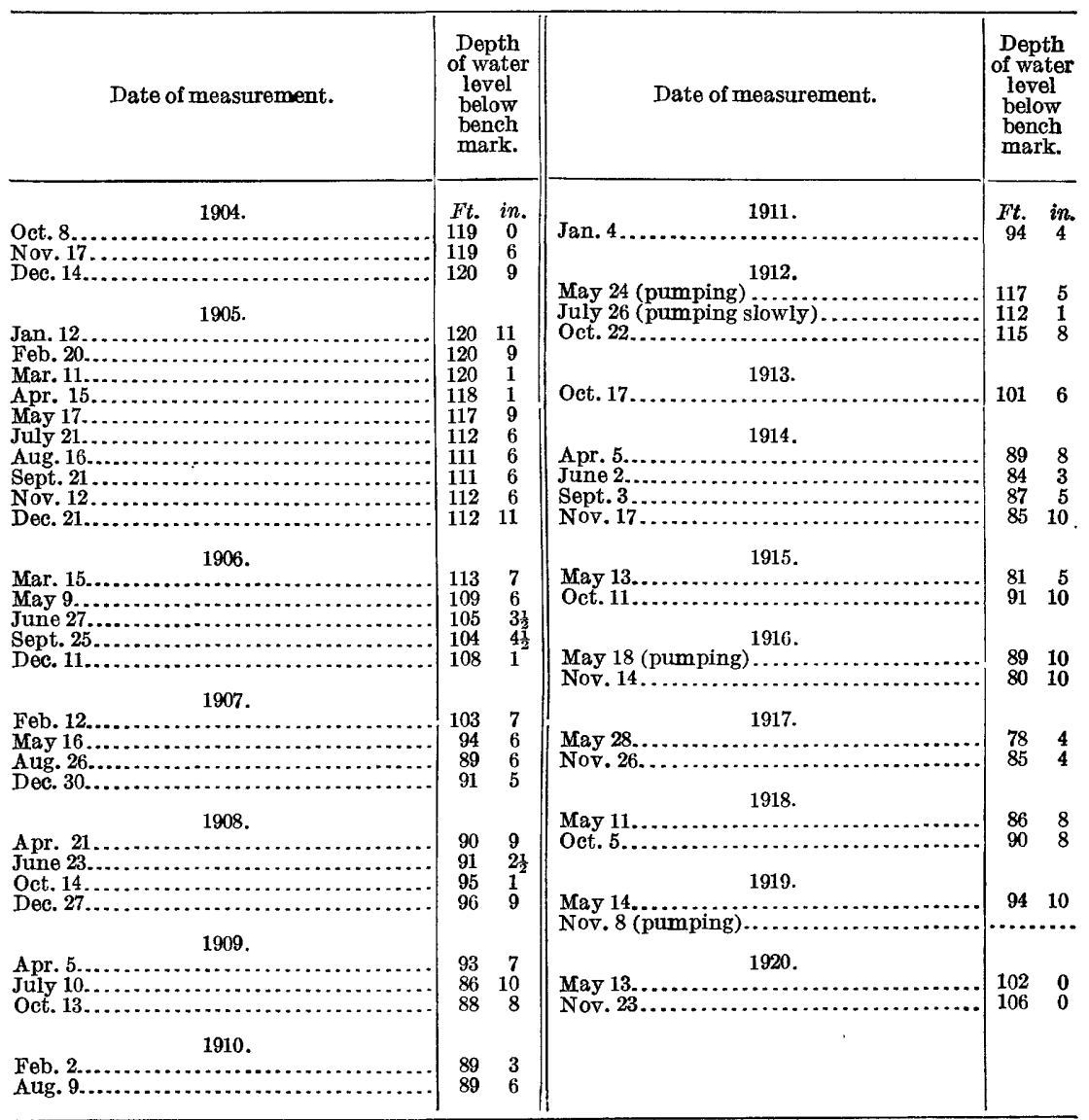


Records of water levels in the valley of southern California-Continued.

\section{H. Heinze, Puente, Pomona quadrangle.}

[Bored well, 127 feet deep, 7 inches in diameter; sunk in 1896; altitude of surface, about 323 feet above sea level; method of lift, wind; use, domestic. Water contains 590 parts per million of dissolved solids. Bench mark: Top of casing, originally 1 foot 7 inches above surface. Between Oct. 14, 1918, and May 10, 1919, 1 foot of casing was removed. Beginning with May 10, 1919, 1 foot has been added to the measurements to make them comparable with earlier measurements. Well No. 117, Water-Supply Paper 219, p. 155.]

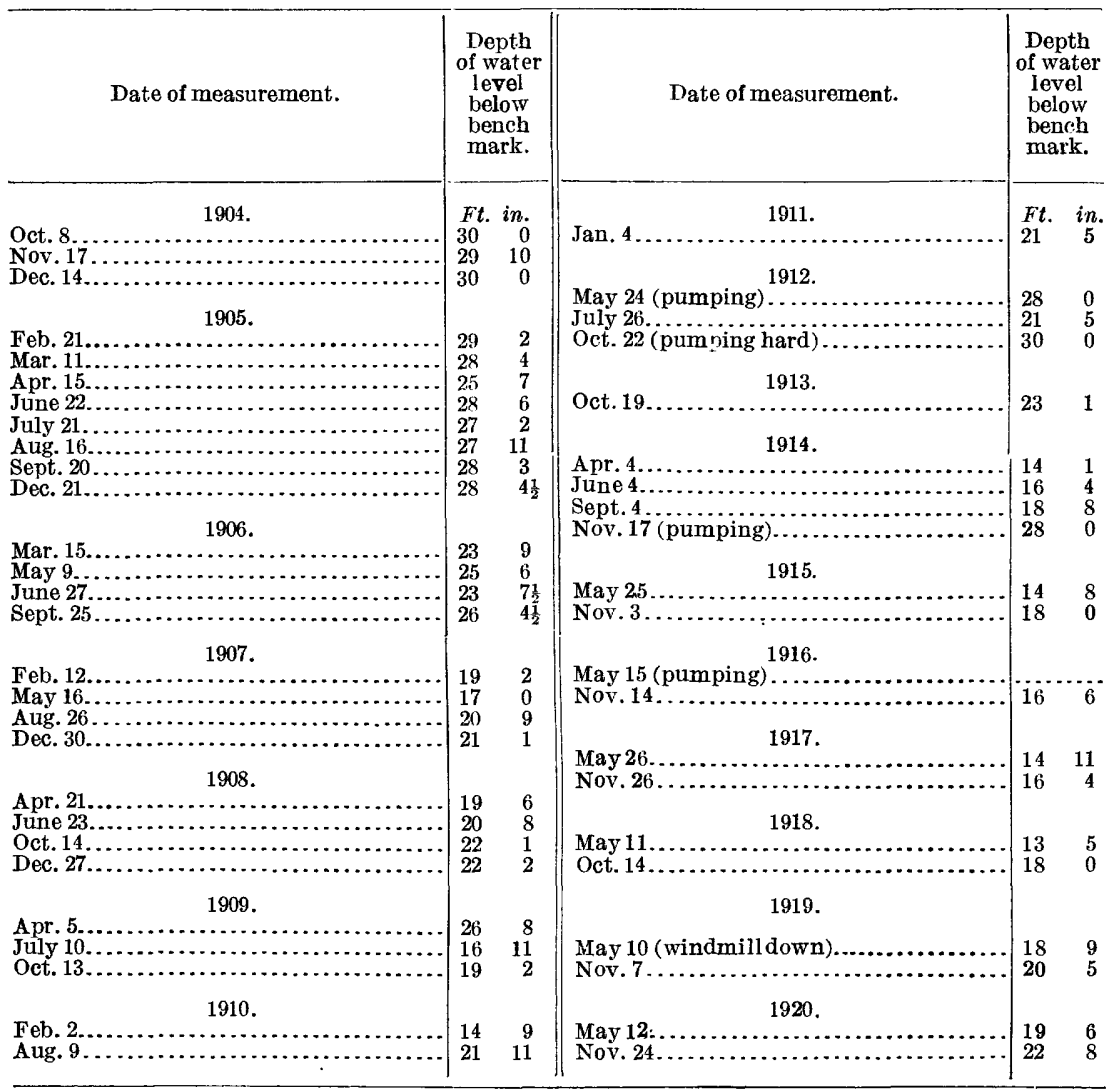

$1820^{\circ}-21-$ W SP 468 
Records of water levels in the valley of southern California-Continued.

44a. E. Fickewith, 2 miles northeast of Puente, Pomona quadrangle.

[Bored well, about 300 feet deep, 10 inches in diameter; altitude of surface, about 352 feet above sea level; method of lift, wind; use, domestic. Water contains 260 parts per million of dissclved solids. Bench mark: Top of casing, originally 1 foot 7 inches above surface. Between Nov. 26, 1917, and May 11, 1918, 1 foot of casing was cut off. Beginning with May 11, 1918, 1 foot has been added to the measurements to make them comparable with earlier ones. Well No. 98, Water-Supply Paper 219, p. 155. Has been measured in conjunction with observation wells, but record has not been published heretcfore.]

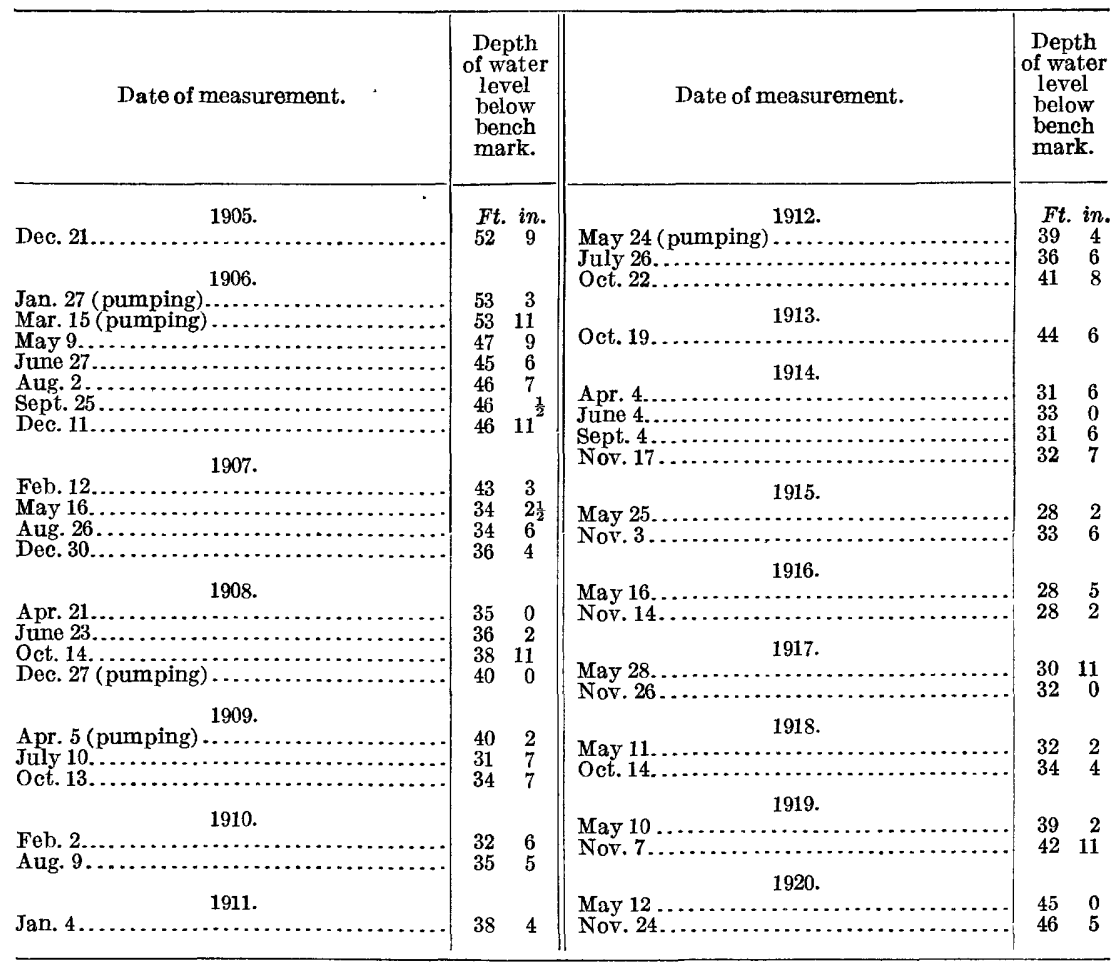

44b. County well, half a mile west of Puente, Pomona quadrangle.

[Bored well, 58 feet deep, 7 inches in diameter; altitude of surface, about 320 feet above sca level; method of lift, wind; use, roads. Water contains 530 parts per million of dissolved solids. Bench mark: Top of casing, 1 foot 4 inches above surface. Well No. 107, Water-Supply Paper 219, p. 155 . Companion well for No. 44.]

\begin{tabular}{|c|c|c|c|}
\hline Date of measurement. & $\begin{array}{l}\text { Depth } \\
\text { of water } \\
\text { level } \\
\text { below } \\
\text { bench } \\
\text { mark. }\end{array}$ & Date of measurement. & $\begin{array}{l}\text { Depth } \\
\text { of water } \\
\text { level } \\
\text { below } \\
\text { bench } \\
\text { mark. }\end{array}$ \\
\hline Nov. 17.................. & $\begin{array}{rl}F t . & \text { in } \\
6 & 10\end{array}$ & $\begin{array}{c}1918 . \\
\text { Oct. } 14 . \ldots \ldots \ldots \ldots \ldots \ldots \ldots \ldots \ldots \ldots \ldots \ldots \ldots\end{array}$ & $\underset{7}{\text { Ft. in }}$. \\
\hline 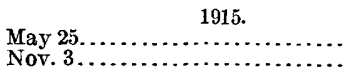 & $\begin{array}{ll}3 & 8 \\
7 & 0\end{array}$ & $\begin{array}{l}\text { May } 10 \ldots 19 . \\
\text { Nov. } 7 \text { (casing filled to } 5 \text { feet } 6 \text { inches) } \ldots\end{array}$ & $\begin{array}{cc}8 & 8 \\
\cdots & -\ldots\end{array}$ \\
\hline $\begin{array}{l}\text { May } 15, \ldots \ldots \ldots \ldots \ldots \ldots \ldots \ldots \ldots \\
\text { Nov. } 14 \ldots \ldots \ldots \ldots \ldots \ldots \ldots \ldots \ldots \ldots \ldots\end{array}$ & $\begin{array}{rr}3 & 11 \\
4 & 2\end{array}$ & $\begin{array}{l}1920 . \\
\text { May } 12 \text { (filled above water surface)...... }\end{array}$ & \\
\hline $\begin{array}{l}\text { May } 26 \ldots 17 . \\
\text { No reading in November. }\end{array}$ & 39 & & \\
\hline
\end{tabular}


Records of water levels in the valley of southern California-Continued.

45. William Rowland, one-fourth mile south of Rowland, Pomona quadrangle.

[Bored well, 90 feet deep, 10 inches in diameter; sunk in 1902; altitude of surface, about 350 feet above sea level; method of lift, wind; use, domestic and stock. Bench mark: Top of casing, 1.0 foot above surface. Well No. 256, Water-Supply Paper 219: p. 160.]

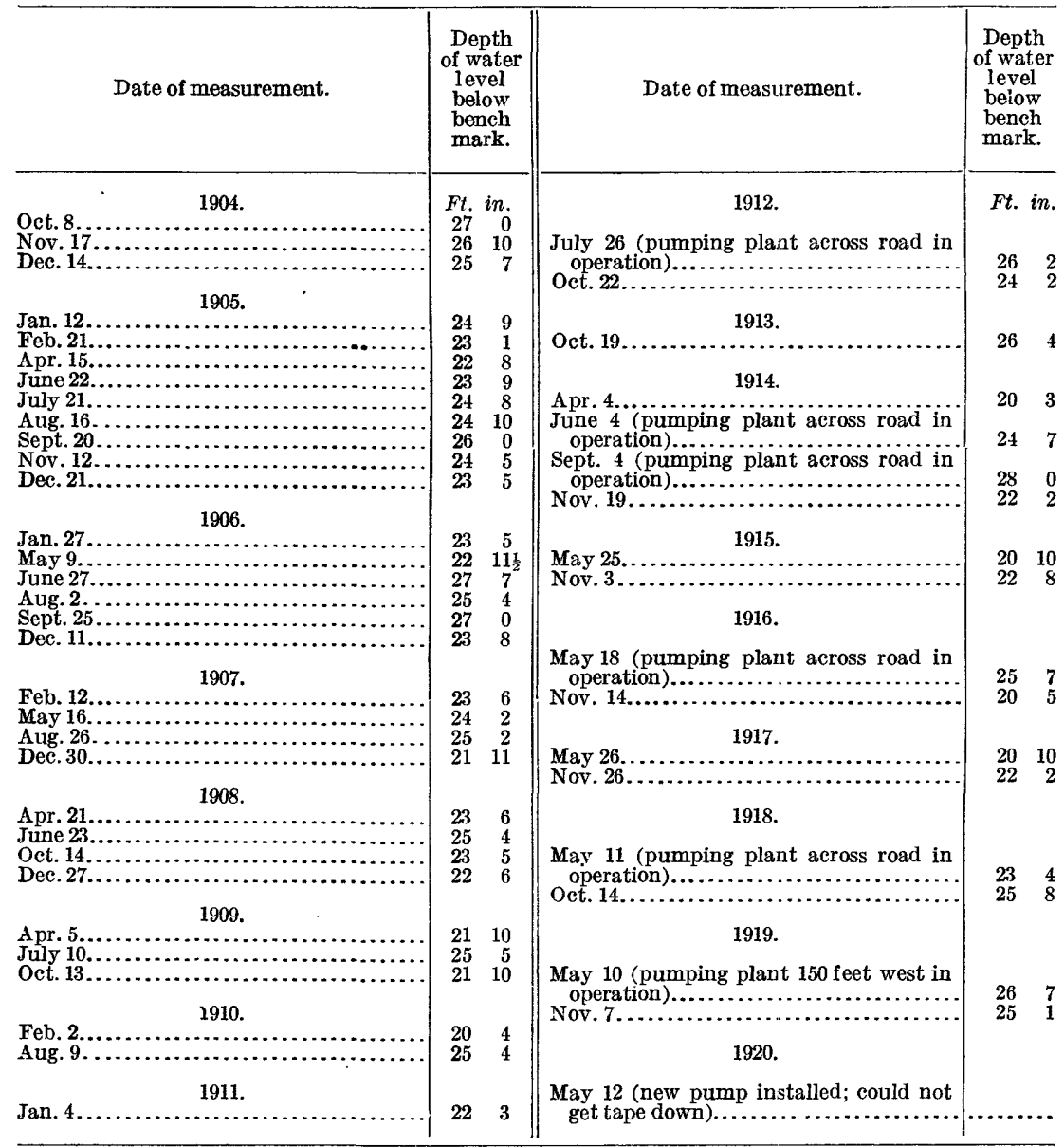


Records of water levels in the valley of southern California-Continued.

45a. William Rowland, one-fourth mile south of Rowland, Pomona quadrangle.

[Companion well for No. 45; 12-inch casing; abandoned. Situated across the road and about 100 feet west of No. 45. Bench mark: Top of casing, 4 inches above surface.]

\begin{tabular}{|c|c|c|c|}
\hline Date of measurement. & $\begin{array}{l}\text { Depth } \\
\text { of water } \\
\text { level } \\
\text { below } \\
\text { bench } \\
\text { mark. }\end{array}$ & Date of measurement. & $\begin{array}{l}\text { Depth } \\
\text { of water } \\
\text { level } \\
\text { below } \\
\text { bench } \\
\text { mark. }\end{array}$ \\
\hline 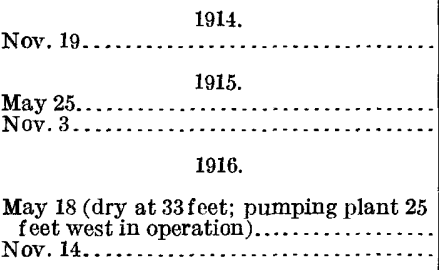 & $\begin{array}{cc}\text { Ft. } & \text { in. } \\
22 & 8 \\
21 & 4 \\
23 & 3\end{array}$ & 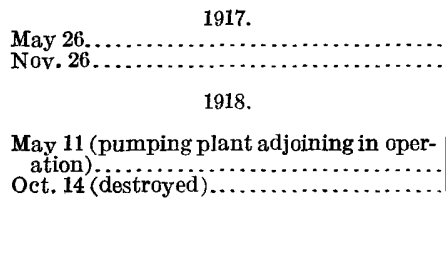 & $\begin{array}{rr}\text { Ft. } & \text { in. } \\
24 & 10 \\
22 & 6 \\
& \\
& \\
& \\
& \\
& \end{array}$ \\
\hline
\end{tabular}

46. B. Yorba, $1 \frac{1}{2}$ miles east of Rowland, Pomona quadrangle.

[Bored well, 50 feet deep, 7 inches in diameter; altitude of surface, about 395 feet above sea level; method of lift, wind; use, domestic. Water contains 600 parts per million of dissolved solids. Bench mark: Top of casing, 1 foot 10 inches above surface. Well No. 135, Water-Supply Paper 219, p. 156.]

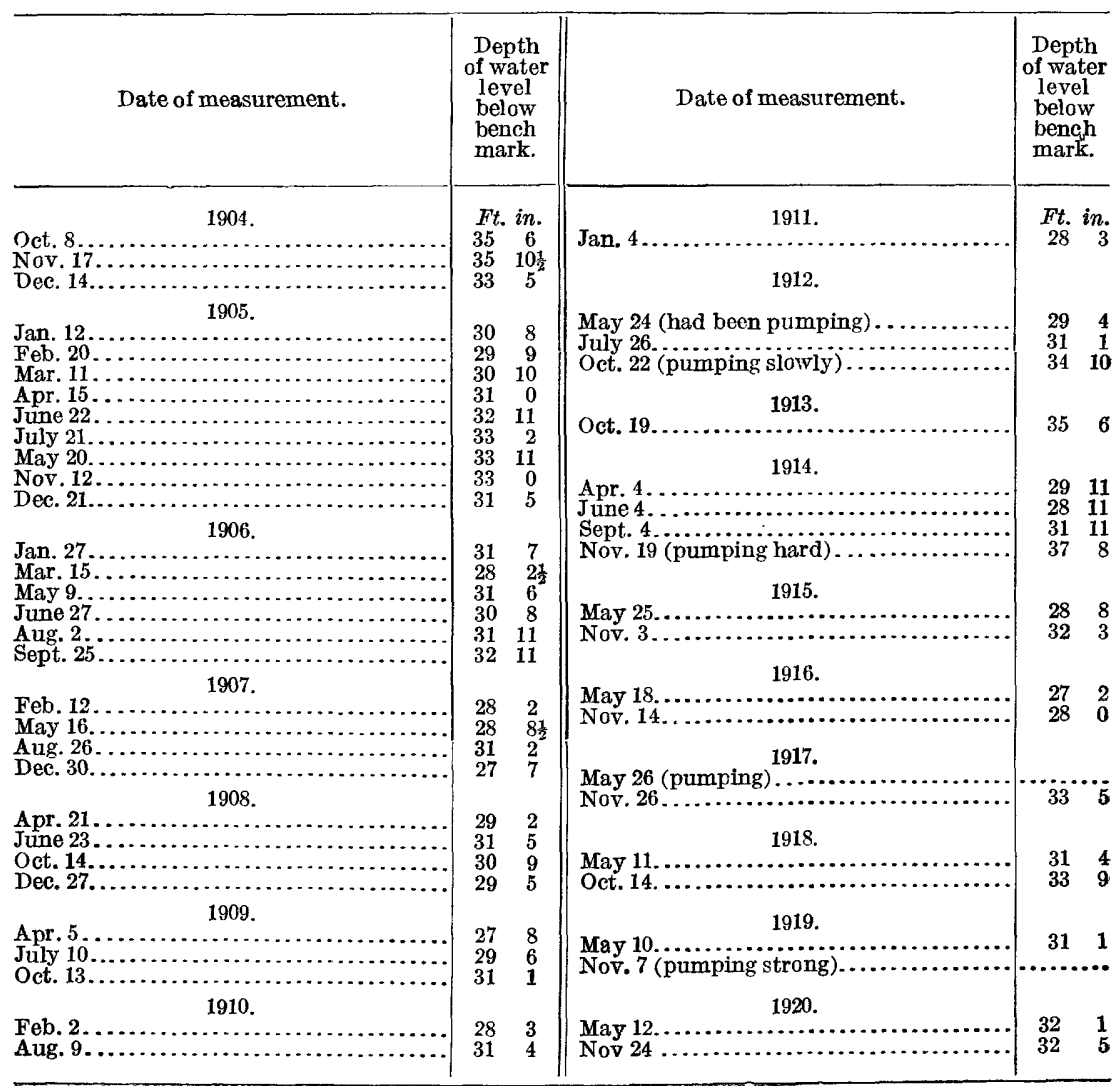


Records of water levels in the valley of southern California-Continued.

47. Mrs. Sadie G. Persons (formerly owned by F. Bowers), Walnut (formerly Lemon), Pomona quadrangle.

[Bored well, 40 feet deep, 7 inches in diameter; sunk in 1900; altitude of surface, about 525 feet above sea level; method of lift, wind; use, domestic. Bench mark: Top of easing, 1 foot above surface. Well No. 257, Water-Supply Paper 219, p. 160.]

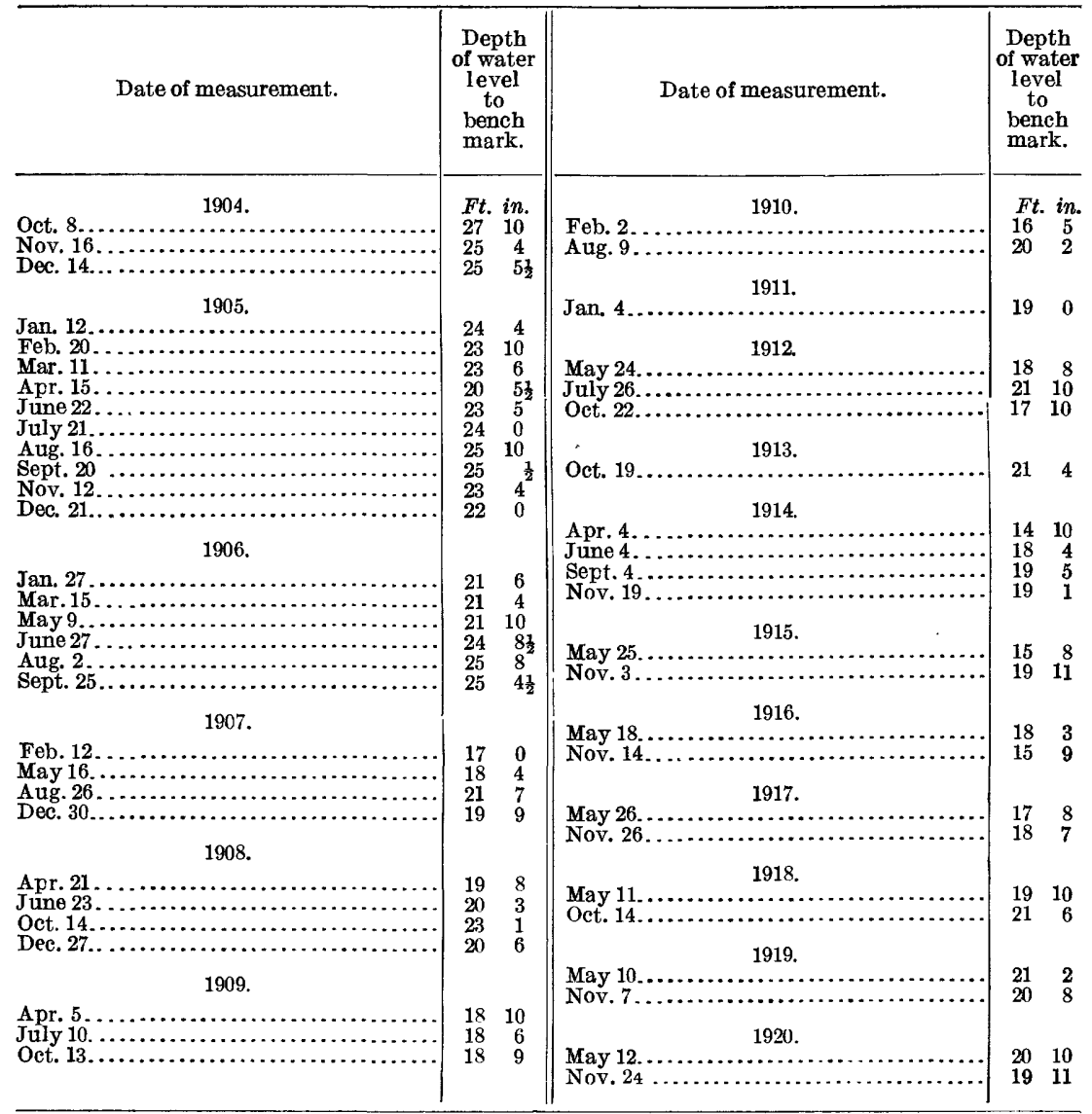


Records of water levels in the valley of southern California-Continued.

48. S. E. Hicks, one-fourth mile west of Spadra, Pomona quadrangle.

[Bored well, 78 feet deep, 7 inches in diameter; altitude of surface, about 700 feet above sea level; method of lift, wind; use, domestic. Bench mark: Top of casing, 1 foot 7 inches above surface. Well No. 258, Water-Supply Paper 219, p. 160.]

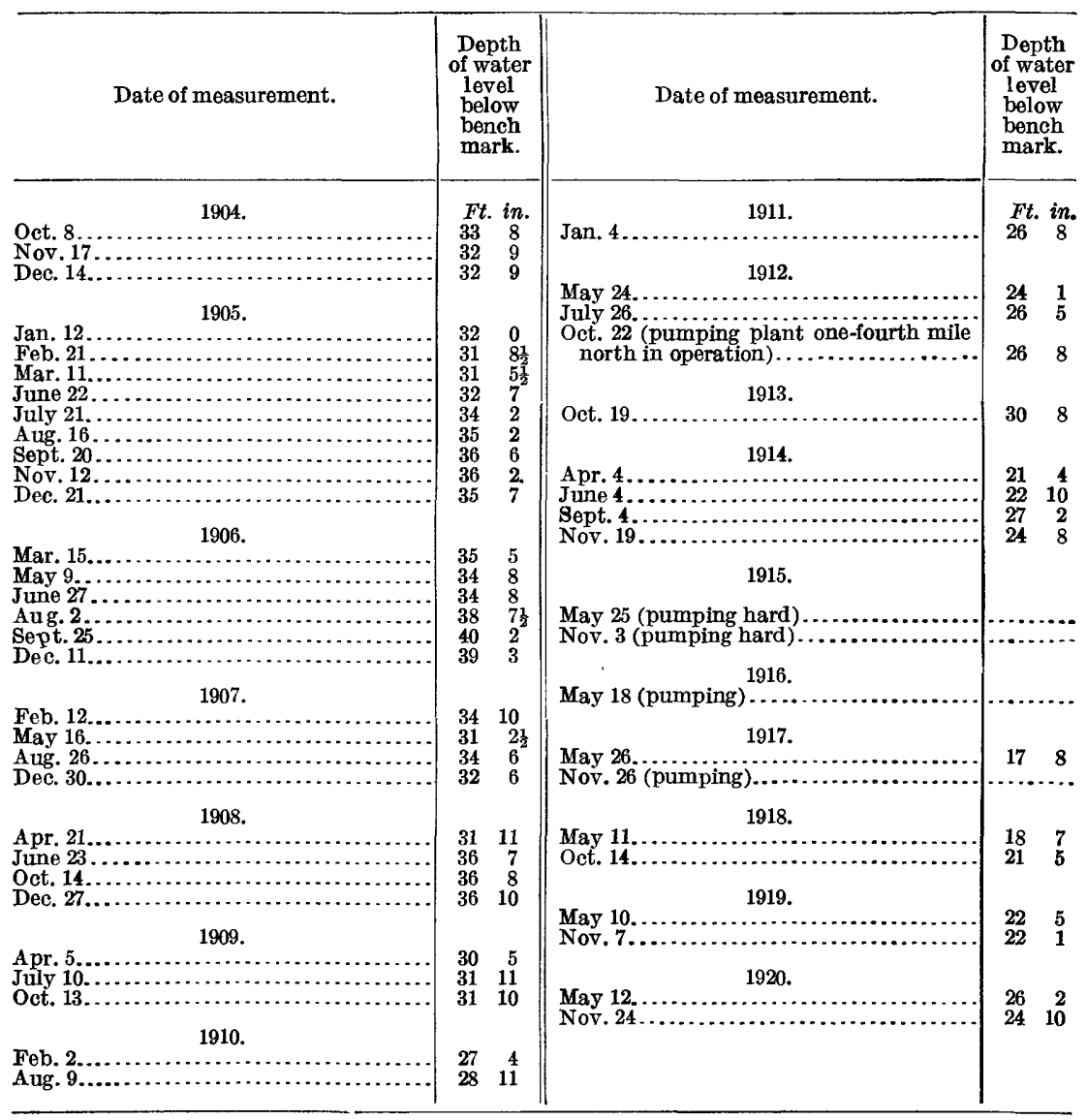


Records of water levels in the valley of southern California-Continued.

\section{8a. County well, Spadra, Pomona quadrangle.}

[Bored well, 55 feet deep, 7 inchesin diameter; altitude of surface, about 705 feet above sea level; method of lift, wind; use, roads. Bench mark: Top of casing, 5 inches below surface. Well No. 259, Water-Supply Paper 219, p. 160. Companion well for No. 48. Has been measured in conjunction with observation wells, but record has not been published heretofore.]

\begin{tabular}{|c|c|c|c|}
\hline Date of measurement. & $\begin{array}{l}\text { Depth } \\
\text { of water } \\
\text { level } \\
\text { below } \\
\text { bench } \\
\text { mark. }\end{array}$ & Date of measurement. & $\begin{array}{l}\text { Depth } \\
\text { of water } \\
\text { level } \\
\text { below } \\
\text { bench } \\
\text { mark. }\end{array}$ \\
\hline 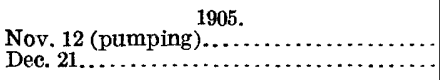 & $\begin{array}{rr}\text { Ft. } & \text { in } \\
36 & 10 \\
36 & 0\end{array}$ & $\begin{array}{l}\text { } 1910 . \\
\text { Feb. } 2 \ldots \ldots \ldots \ldots \ldots \ldots \ldots \\
\text { Aug. } 9 . \ldots \ldots \ldots \ldots \ldots \ldots \ldots\end{array}$ & $\begin{array}{ll}F t . & \text { in. } \\
27 & 2 \\
28 & 8\end{array}$ \\
\hline 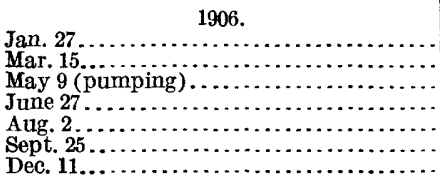 & $\begin{array}{rr}36 & 10 \\
36 & 7 \\
38 & 6 \\
37 & 2 \\
39 & 3 \\
40 & 5 \\
39 & 9\end{array}$ & 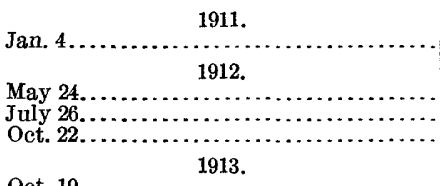 & $\begin{array}{l}28 \\
26 \\
31 \\
27\end{array}$ \\
\hline 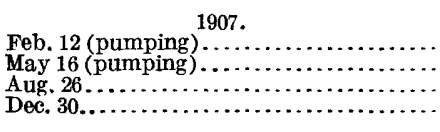 & $\begin{array}{ll}35 & 21 \\
31 & 2 \\
35 & 21 \\
32 & 9\end{array}$ & 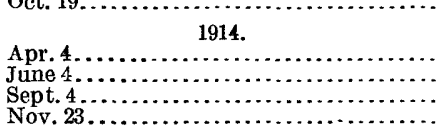 & $\begin{array}{l}20 \\
22 \\
29 \\
26\end{array}$ \\
\hline 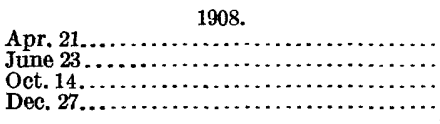 & $\begin{array}{rr}32 & 0 \\
36 & 11 \\
37 & 1 \\
34 & 10\end{array}$ & 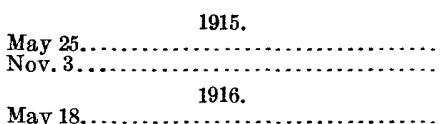 & $\begin{array}{l}20 \\
25\end{array}$ \\
\hline \begin{tabular}{l}
\multicolumn{1}{c}{1909.} \\
Apr. $5 \ldots \ldots \ldots \ldots \ldots \ldots \ldots$ \\
July $10 \ldots \ldots \ldots \ldots \ldots \ldots \ldots$
\end{tabular} & $\begin{array}{ll}37 & 6 \\
32 & 4 \\
32 & 0\end{array}$ & $\begin{array}{l}\text { Nov. } 14 \ldots \ldots \ldots \ldots \ldots \ldots \\
\text { May } 26 \ldots \ldots \ldots \ldots \ldots \ldots \ldots \ldots\end{array}$ & $17 \quad 11$ \\
\hline
\end{tabular}

49. Sidney Deacon, 2 miles west of San Dimas, Pomona quadrangle.

[Bored.well, 160 feet deep, 12 inches in diameter; al titude of surface, about 825 feet above sea level; method of lift, steam; water not used. Bench mark not known. Well No. 149, Water-Supply Paper 219, p. 156.]

\begin{tabular}{|c|c|c|c|}
\hline Date of measurement. & $\begin{array}{c}\text { Depth } \\
\text { of water } \\
\text { level } \\
\text { below } \\
\text { bench } \\
\text { mark. }\end{array}$ & Date of measurement. & $\begin{array}{l}\text { Depth } \\
\text { of water } \\
\text { level } \\
\text { below } \\
\text { bench } \\
\text { mark. }\end{array}$ \\
\hline 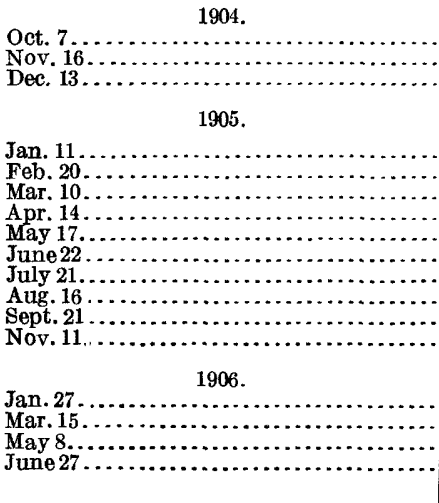 & $\begin{array}{ll}123 & 6 \\
123 & 5 \\
127 & 0 \\
125 & 0 \\
124 & 8 \\
125 & 1 \frac{1}{2} \\
125 & 5 \\
125 & 5 \\
125 & 7 \\
126 & 0 \\
& \\
124 & 6 \\
124 & 3 \\
125 & 2 \\
124 & 6\end{array}$ & 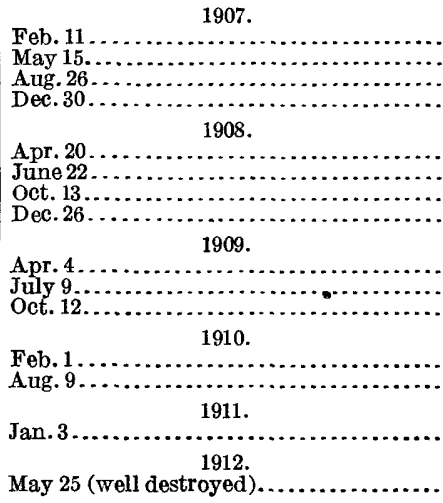 & $\begin{array}{lr}\text { Ftt. } & \text { in. } \\
35 & 3 \frac{1}{2} \\
39 & 6 \\
43 & 3 \\
46 & 9 \\
& \\
47 & 11 \\
49 & 3 \\
62 & 7 \\
67 & 5 \\
& \\
65 & 4 \\
71 & 9 \\
75 & 0 \\
& \\
76 & 8 \\
82 & 4 \\
& \\
86 & 4\end{array}$ \\
\hline
\end{tabular}


Records of water levels in the valley of southern California-Continued.

50. William Terry, $1 \frac{1}{2}$ miles southwest of San Dimas, Pomona quadrangle.

[Bored well, 222feet deep, 10inches in diameter; sunk in 1900; altitude of surface,about 855 feet above sea level; water not used. Bench mark: Top of casing, 6 inches above surface. Well No. 144, Water-Supply Paper 219, p. 156.]

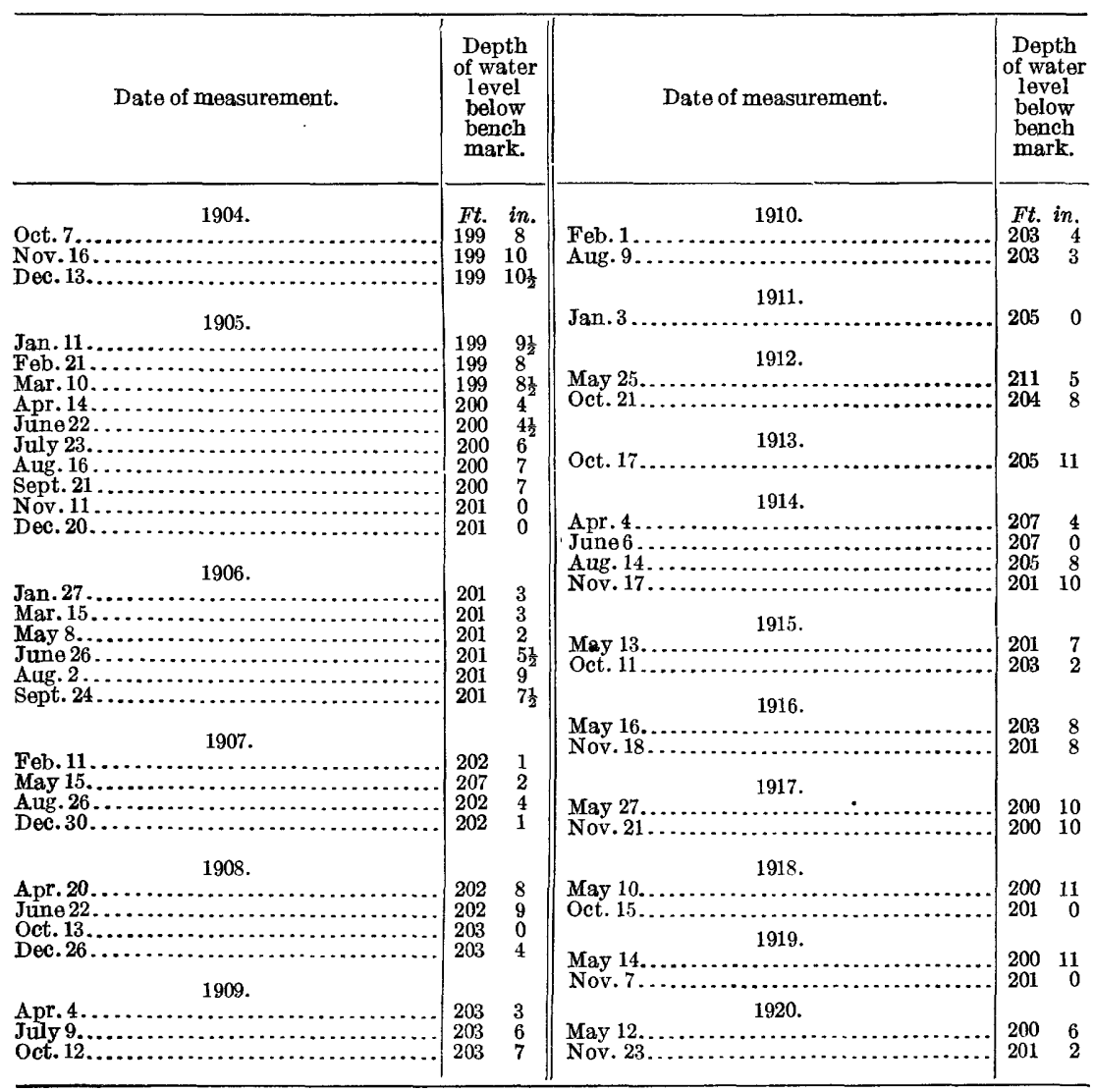


Records of water levels in the valley of southern California-Continued.

51. Azusa Irrigation Co., San Dimas Wash, Pomona quadrangle.

[Bench mark not known.]

\begin{tabular}{|c|c|c|c|}
\hline Date of measurement. & $\begin{array}{l}\text { Depth } \\
\text { of water } \\
\text { level } \\
\text { below } \\
\text { bench } \\
\text { mark. }\end{array}$ & Date of measurement. & $\begin{array}{l}\text { Depth } \\
\text { of water } \\
\text { level } \\
\text { below } \\
\text { bench } \\
\text { mark. }\end{array}$ \\
\hline 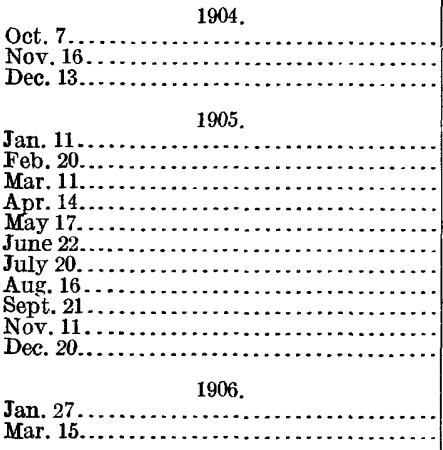 & $\begin{array}{lc}\text { Ft. } & \text { in. } \\
97 & 2 \\
97 & 8 \\
98 & 11 \\
& \\
& \\
99 & 1 \\
98 & 4 \\
97 & 4 \\
95 & 6 \\
94 & 3 \\
94 & 1 \\
95 & 4 \\
96 & 4 \\
97 & 4 \\
98 & 6 \\
99 & 0 \\
& \\
97 & 10 \\
97 & 2 \frac{1}{2}\end{array}$ & 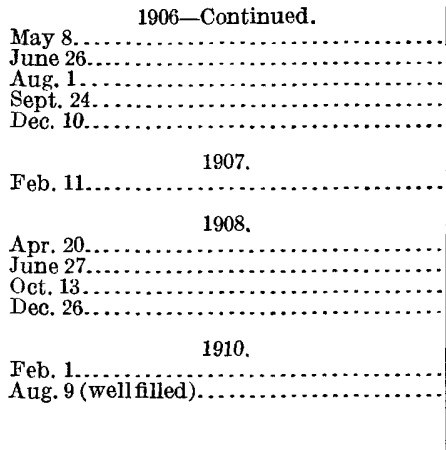 & \begin{tabular}{|rr}
93 & $1 \frac{1}{2}$ \\
& \\
52 & 0 \\
53 & 7 \\
56 & 11 \\
59 & 9 \\
& \\
53 & 6 \\
$\ldots \ldots$ &
\end{tabular} \\
\hline
\end{tabular}

52. J. R. Dennison (formerly owned by Emil Firth), San Dimas Wash, Pomona quadrangle.

[Method of lift, gasoline engine; use, domestic. Bench mark: Top of pump base, 2 feet 6 inches below surface. Well No. 246, Water-Supply Paper 219, p. 159.]

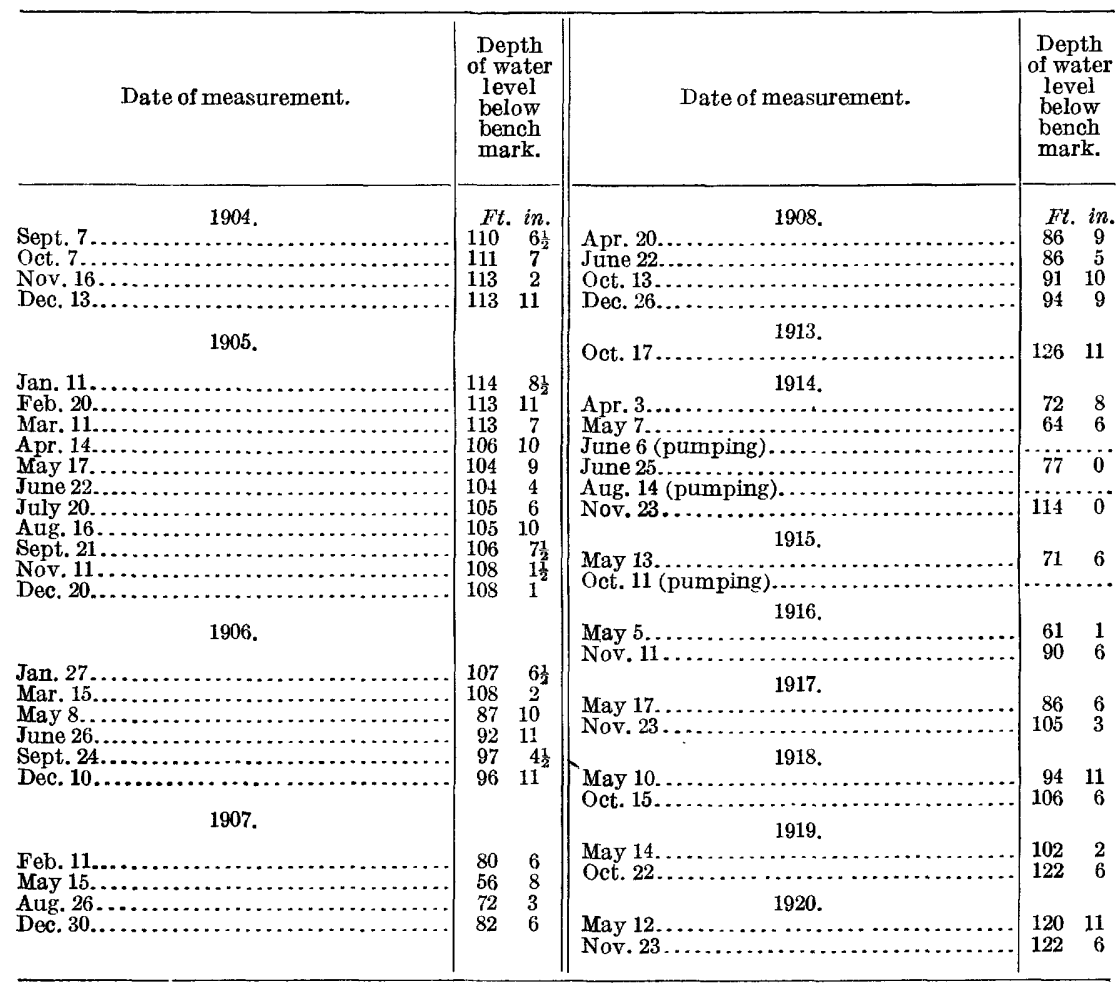


Records of water levels in the valley of southern California-Continued.

53. Charles Alley, 1 mile northwest of Lordsburg, Pomona quadrangle.

[Bored well, 175 feet deep, 10 inches in diameter; altitude of surface, about 1,120 feet above sea level; method of lift, wind; use, stock. Bench mark: Top of casing, 10 inches above surface. Well No. 250 , Water-Supply Paper 219, p. 159.]

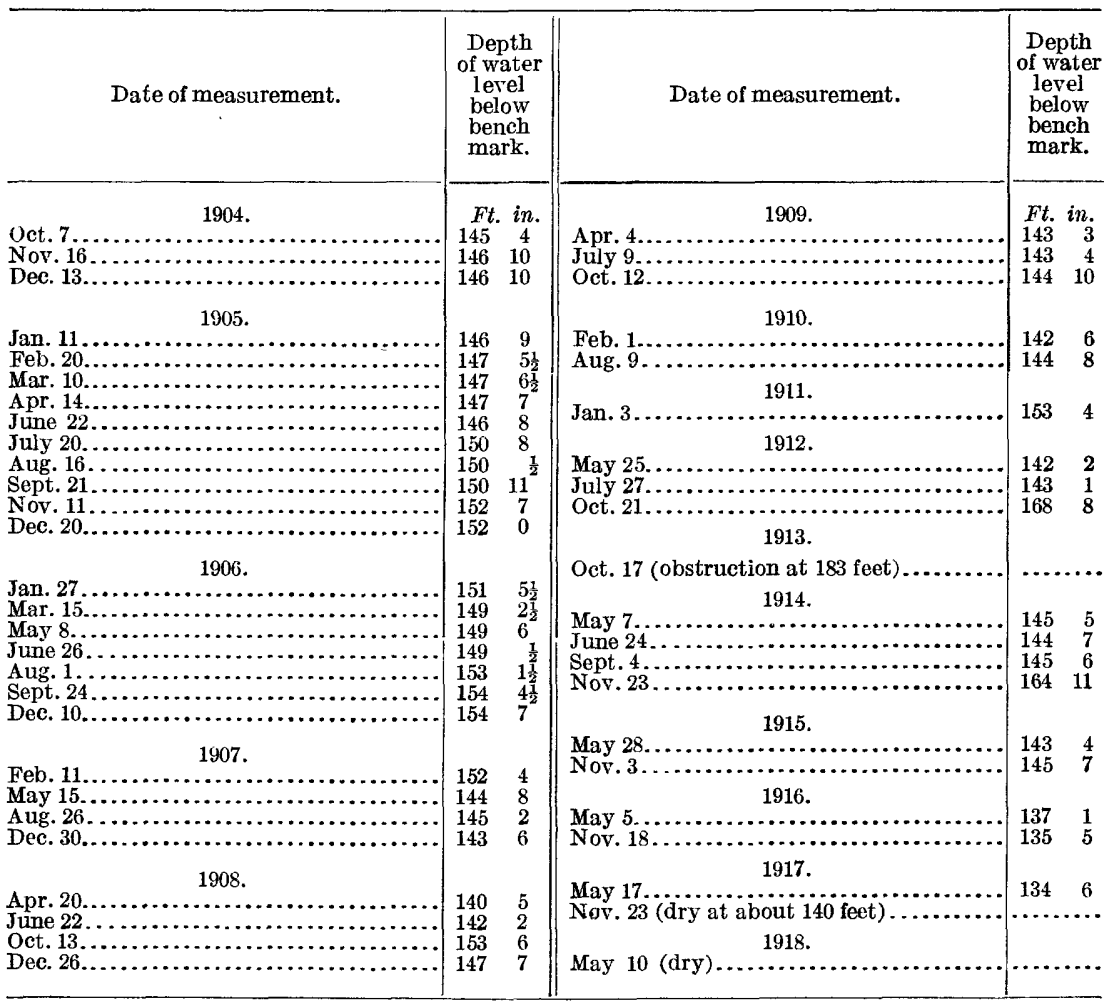

\section{George Silvey (formerly owned by Mr. Massey), three-fourths mile northeast of Lordsburg,} Pomona quadrangle.

[Bored well, 200 + feet deep, 10inches in diameter; sunk in 1898; altitude of surface, about 1,165 feet above sea level; water not used. Bench mark: Top of casing, 1 foot 5 inches above surface. Well No. 67, Water-Supply Paper 219, p. 153.]

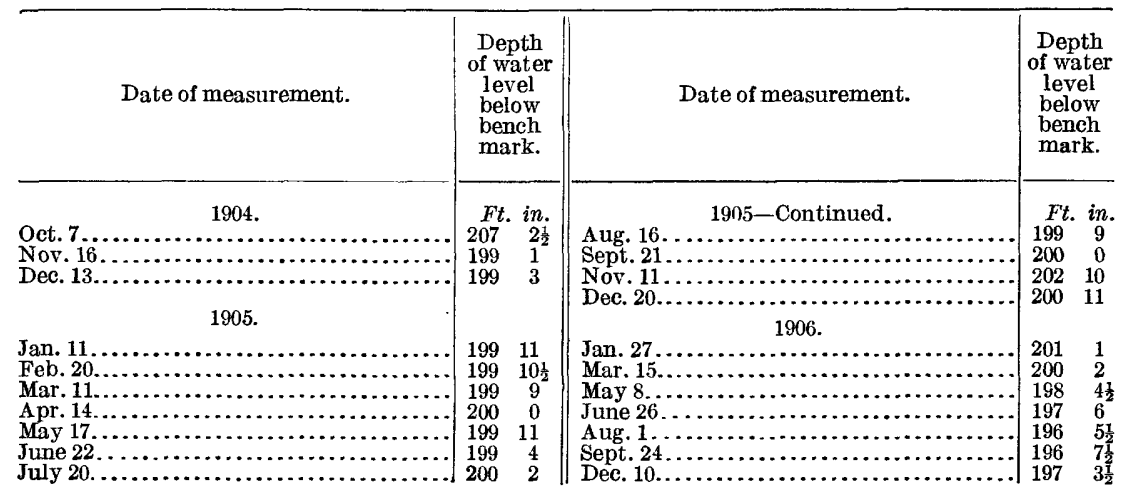


Records of water levels in the valley of southern California-Continued.

54. George Silvey-Continued.

\begin{tabular}{|c|c|c|c|}
\hline Date of measurement. & $\begin{array}{l}\text { Depth } \\
\text { of water } \\
\text { level } \\
\text { below } \\
\text { bench } \\
\text { mark. }\end{array}$ & Date of measurement. & $\begin{array}{l}\text { Depth } \\
\text { of water } \\
\text { level } \\
\text { below } \\
\text { bench } \\
\text { mark. }\end{array}$ \\
\hline 1307 & $F t$, in & 1913. & Ft in \\
\hline$\ldots \ldots \ldots \ldots \ldots \ldots \ldots \ldots$ & 1963 & Oct. $17 \ldots \ldots \ldots$ & 1736 \\
\hline 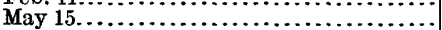 & $191 \quad 1$ & Vel. $18 \ldots . . . . . .$. & \\
\hline (n) & 183 & 1914 & \\
\hline Dec, $30 \ldots \ldots \ldots \ldots$ & 163 & 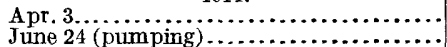 & $\begin{array}{cr}169 & 3 \\
\ldots \ldots & \ldots\end{array}$ \\
\hline $\begin{array}{cc} & 1908 .\end{array}$ & 147 & Sept. 4 . & 1692 \\
\hline 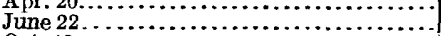 & $\begin{array}{ll}147 & 1 \\
146 & 0\end{array}$ & 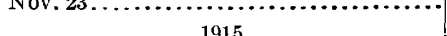 & \\
\hline$\ldots \ldots \ldots \ldots \ldots \ldots \ldots \ldots$ & 1513 & May 28. 1915. & 154 \\
\hline Dec. $26 \ldots . . . \ldots$ & 152 & Oct. $11 \ldots \ldots \ldots \ldots \ldots$ & 157 \\
\hline Apr. $4 \ldots \ldots \ldots \ldots \ldots \ldots \ldots$ & 151 & May 5 (pumping) 1916. & \\
\hline July 9 & 153 & Nov $18, \ldots \ldots \ldots$ & 12310 \\
\hline $\begin{array}{r}\text { Oct. } 12 \ldots \ldots \ldots \ldots \ldots \ldots \ldots \ldots \ldots \ldots \ldots \ldots \ldots \ldots \ldots \ldots \ldots \ldots \\
\text { Feb. } 1 \text { (pumping) } 1910 .\end{array}$ & 155 & $\begin{array}{l}1917 . \\
\text { May } 17 \text { (pumping) } \ldots \ldots \ldots \ldots \ldots \ldots \ldots \ldots \ldots \ldots \\
\text { Nov. } 23 \ldots \ldots \ldots \ldots \ldots \ldots \ldots \ldots \ldots \ldots \ldots \ldots \ldots \ldots \ldots \ldots\end{array}$ & $143 \cdots$ \\
\hline Aug. $9 . \ldots \ldots \ldots \ldots$ & 140 & 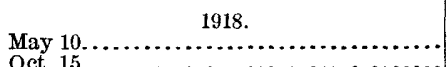 & $148 \quad 8$ \\
\hline Jan, $3 \ldots \ldots \ldots \ldots \ldots \ldots \ldots \ldots$ & 154 & $\begin{aligned} & 1919 .\end{aligned}$ & \\
\hline $\begin{array}{c}1912 . \\
\text { May } 25 . \ldots \ldots \ldots \ldots \ldots \ldots \ldots \ldots \ldots \ldots \ldots \ldots \ldots\end{array}$ & $147 \quad 0$ & 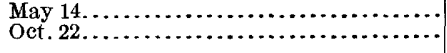 & $\begin{array}{ll}167 & 10 \\
186 & 11\end{array}$ \\
\hline 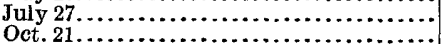 & 1508 & 1920 & 188 \\
\hline & & May 14. & 188 \\
\hline
\end{tabular}

55. Ontario Water Co., 1 mile north of Claremont, Cucamonga quadrangle.

[Bored well, 160 feet deep, 10 inches in diameter; sunk in 1900; altitude of surface, about 1,265 feet above sea level; method of lift, compressed air; use, irrigation. Bench mark: Top of casing, 1.0 foot above surface. Well No. 265, Water-Supply Paper 219, p. 150.]

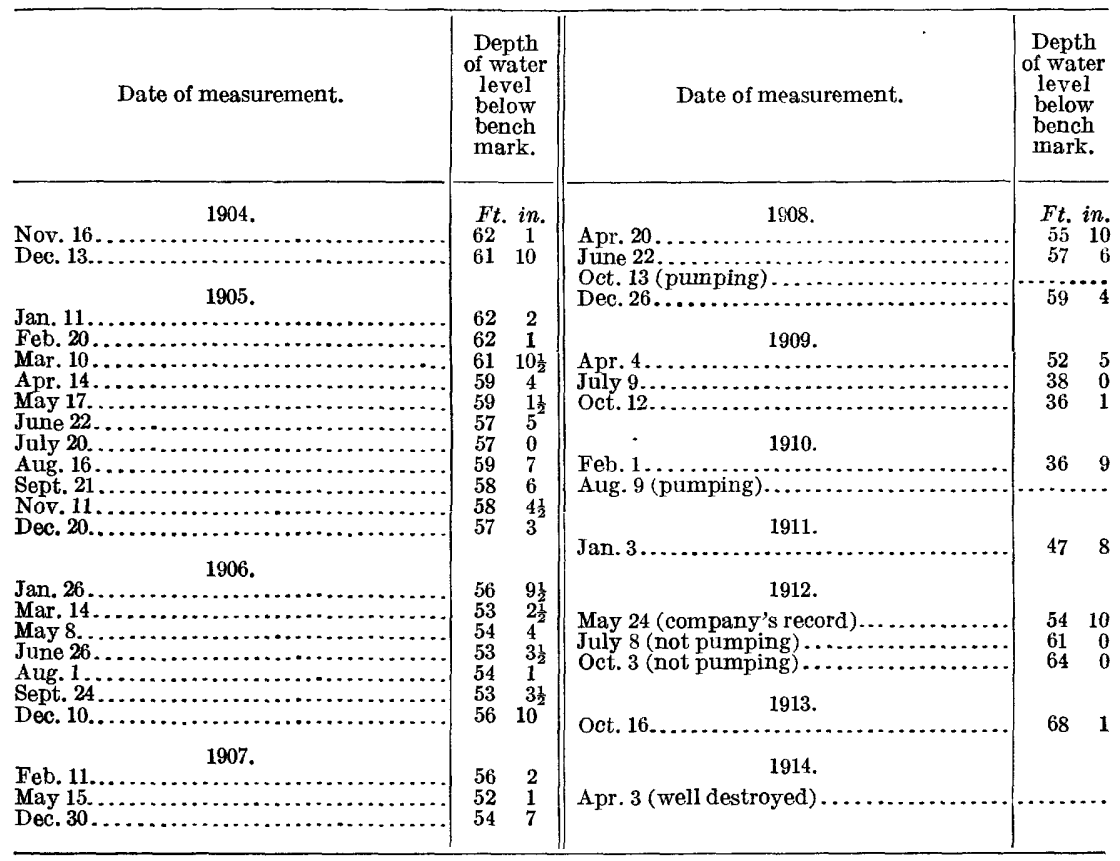




\section{Records of water levels in the valley of southern California-Continued.}

55a. Onfario Water Co., 1 mile north of Claremont, Cucamonga quadrangle.

[Bored well, 225 feet deep, 10 inches in diameter; sunk in 1900; altitude of surface, about 1,265 feet above sea level; method of lift, compressed air; use, irrigation. Bench mark: Top casing, 3 feet 3 inches below surface. Well No. 265a, Water-Supply Paper 219, p. 150. Companion well for No. 55. Has been measured in conjunction with observation wells, but record not published hitherto.]

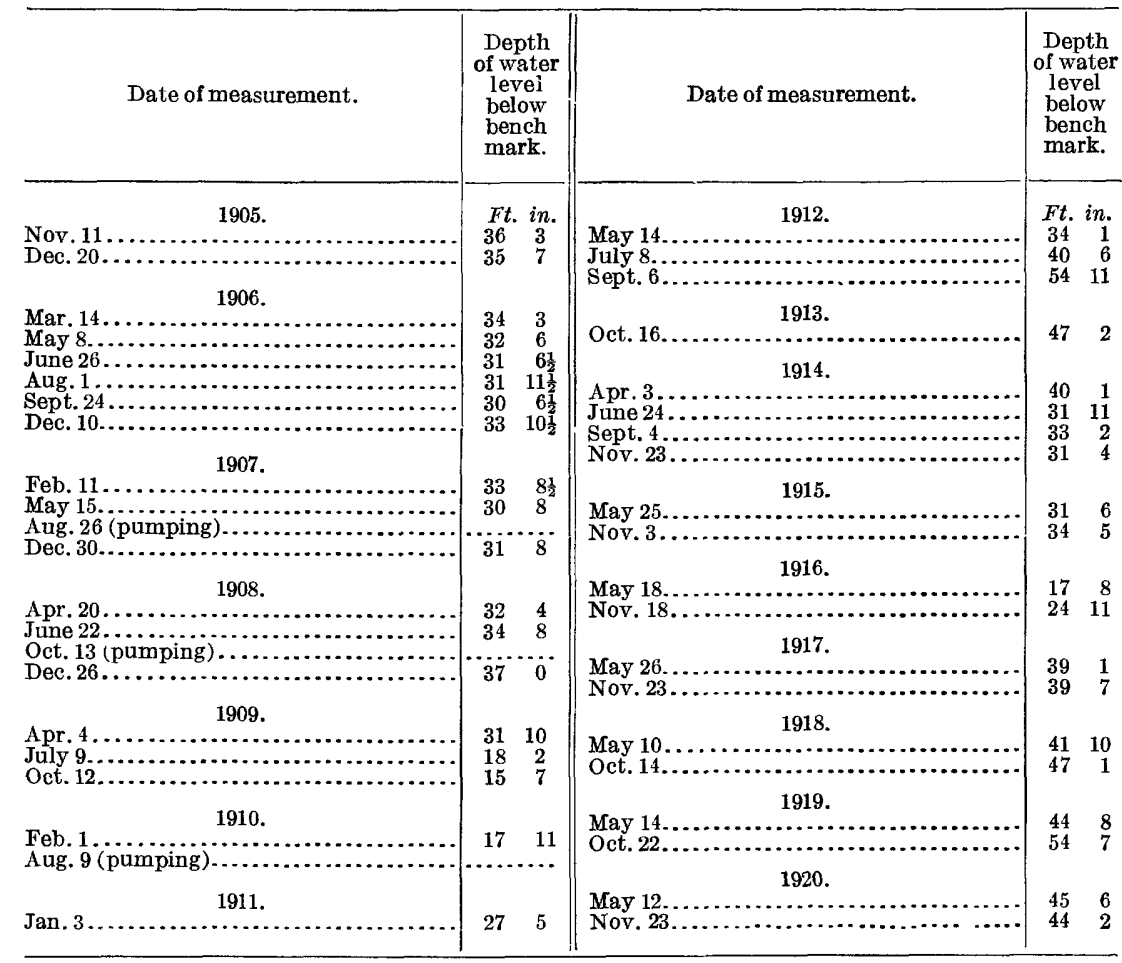

55b. Ontario Water Co., 1 mile north of Claremont, Cucamonga quadrangle.

[Bored well, 225 feet deep, 10 inches in diameter; sunk in 1900; altitude of surface, about 1,270 feet above sea level; method of lift, compressed air; use, irrigation. Bench mark: Top of casing, 1 foot 6 inches below surface. Well No. 265c, Water-Supply Paper 219, p. 150. Companion well for No. 55a.]

\begin{tabular}{|c|c|c|c|}
\hline Date of measurement. & $\begin{array}{l}\text { Depth } \\
\text { of water } \\
\text { level } \\
\text { below } \\
\text { bench } \\
\text { mark. }\end{array}$ & Date of measurement. & $\begin{array}{l}\text { Deptlı } \\
\text { of water } \\
\text { level } \\
\text { below } \\
\text { bench } \\
\text { mark. }\end{array}$ \\
\hline Nov. $23 \ldots \ldots \ldots \ldots \ldots \ldots \ldots \ldots \ldots \ldots \ldots$ & Ft. $\stackrel{\text { in. }}{\mathbf{4}}$ & 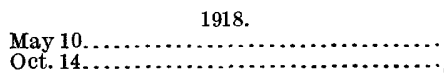 & $\begin{array}{rr}\text { Ft. } & \text { in. } \\
56 & 2 \\
65 & 0\end{array}$ \\
\hline 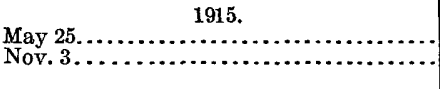 & $\begin{array}{ll}42 & 1 \\
51 & 9\end{array}$ & 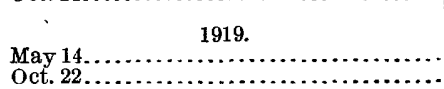 & $\begin{array}{ll}61 & 6 \\
70 & 1\end{array}$ \\
\hline 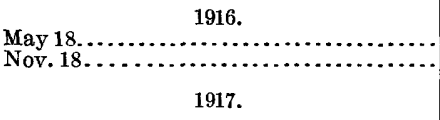 & $\begin{array}{ll}31 & 4 \\
34 & 6\end{array}$ & $\begin{array}{c}1920 . \\
\text { May } 12 \ldots \ldots \ldots \ldots \ldots \ldots \ldots \ldots \ldots \ldots \ldots \ldots \ldots \ldots \ldots \ldots \ldots \ldots \ldots \ldots \ldots\end{array}$ & $\begin{array}{ll}58 & 6 \\
56 & 6\end{array}$ \\
\hline 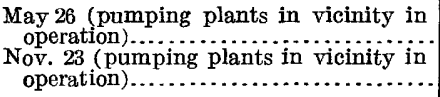 & $\begin{array}{rr}55 & 10 \\
55 & 0\end{array}$ & & \\
\hline
\end{tabular}


Records of water levels in the valley of southern California-Continued.

\section{Robert Bieley, Claremont, Cucamonga quadrangle.}

[Bored well, 117 feet deep; 10 inches in diameter; sunk in 1900; altitude of surface, about 1,155 feet above sea level; method of lift, wind; use, domestic and stock. Bench mark: Top of casing, 1 foot 6 inches above surface. Well No. 250, Water-Supply Paper 219, p. 149.]

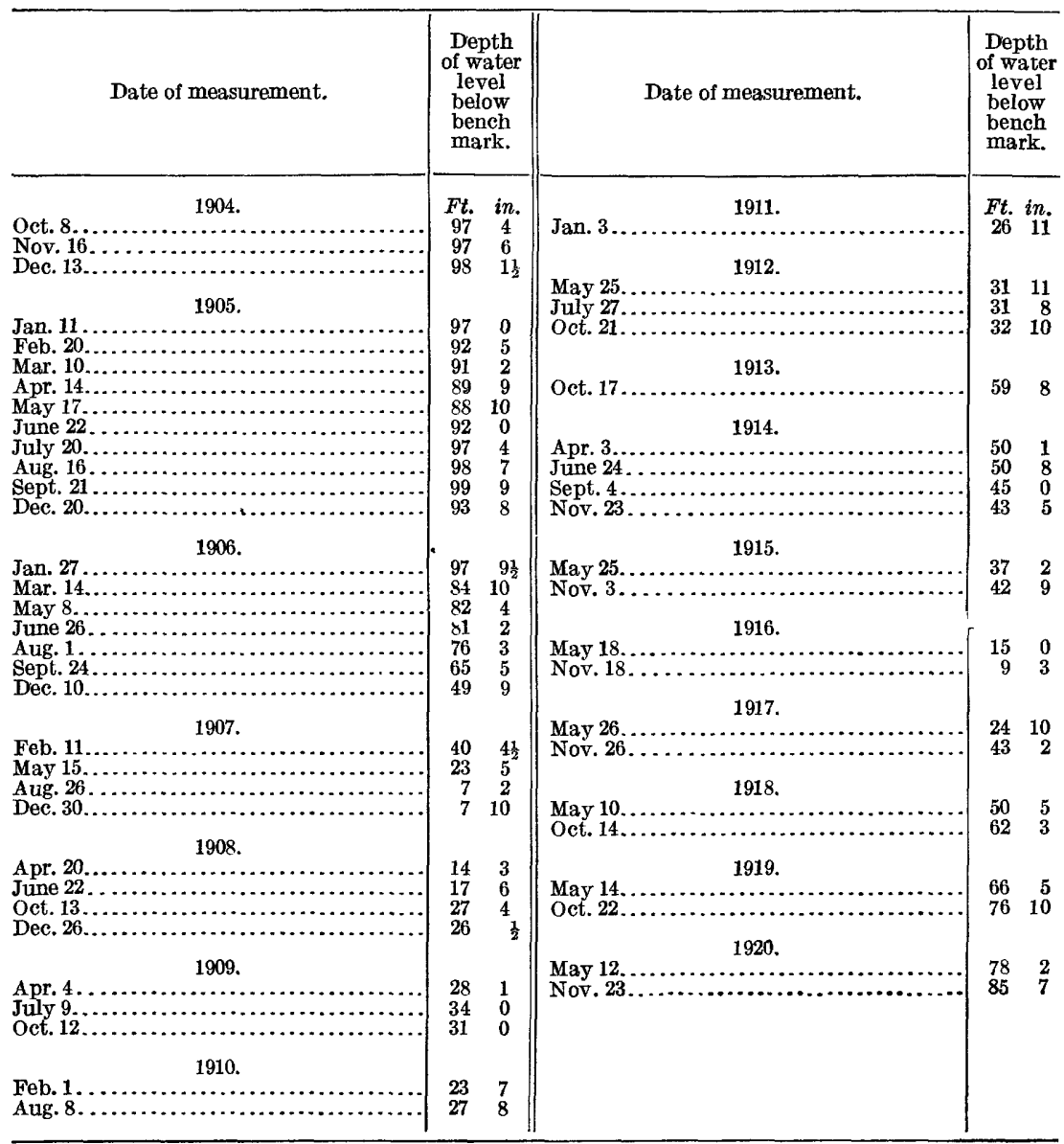


Records of water levels in the valley of southern California-Continued.

57. San Antonio Water Co., half a mile southwest of Claremont, Cucamonga quadrangle.

[Bored well, 558 feet deep, 12 inches in diameter; al titude of surface, about 1,121 feet above sea level; water not used. Bench mark not known. Well No. 242, Water-Supply Paper 219, p. 149.]

\begin{tabular}{|c|c|c|c|}
\hline Date of measurement. & $\begin{array}{c}\text { Depth } \\
\text { of water } \\
\text { level } \\
\text { below } \\
\text { bench } \\
\text { mark. }\end{array}$ & Date of measurement. & $\begin{array}{l}\text { Depth } \\
\text { of water } \\
\text { level } \\
\text { below } \\
\text { bench } \\
\text { mark. }\end{array}$ \\
\hline 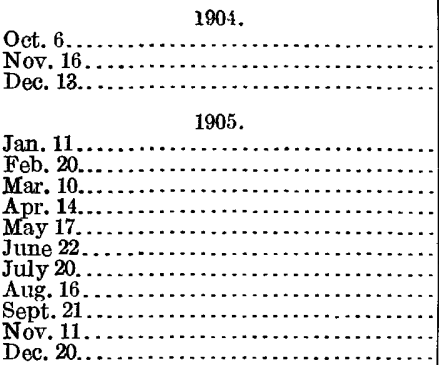 & $\begin{array}{lc}\text { Ft. } & \text { in. } \\
158 & 5 \\
156 & 2 \\
155 & 0 \\
& \\
153 & 1 \frac{1}{2} \\
151 & 1 \\
150 & 2 \\
148 & 7 \\
147 & 1 \\
148 & 7 \\
150 & 10 \\
150 & 8 \\
152 & 6 \frac{1}{2} \\
152 & 1 \\
149 & 1\end{array}$ & 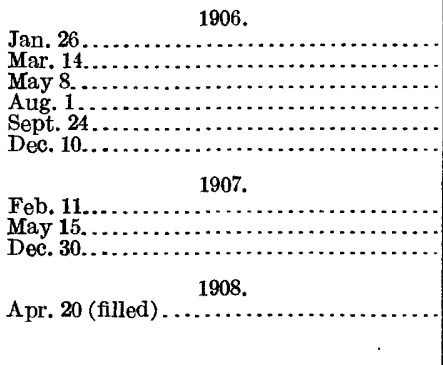 & $\begin{array}{rc}F t . & \text { in. } \\
149 & 6 \\
144 & 3 \\
141 & 2 \\
146 & 8 \\
149 & 8 \frac{1}{2} \\
149 & 8 \\
& \\
& \\
143 & 8 \\
102 & 7 \\
29 & 11 \frac{1}{2}\end{array}$ \\
\hline
\end{tabular}

57a. J. W. Romick, half a mile southwest of Claremont, Cucamonga quadrangle.

[Well about 200 feet deep; altitude of surface, about 1,125 feet above sea level; method of lift, wind; use, irrigation. Bench mark: Top of casing, 3 inches above surface. Well No. 300, Water-Supply Paper 219, p. 151. Companion well for No. 57. Has been measured in conjunction with observation wells but record not published heretofore.]

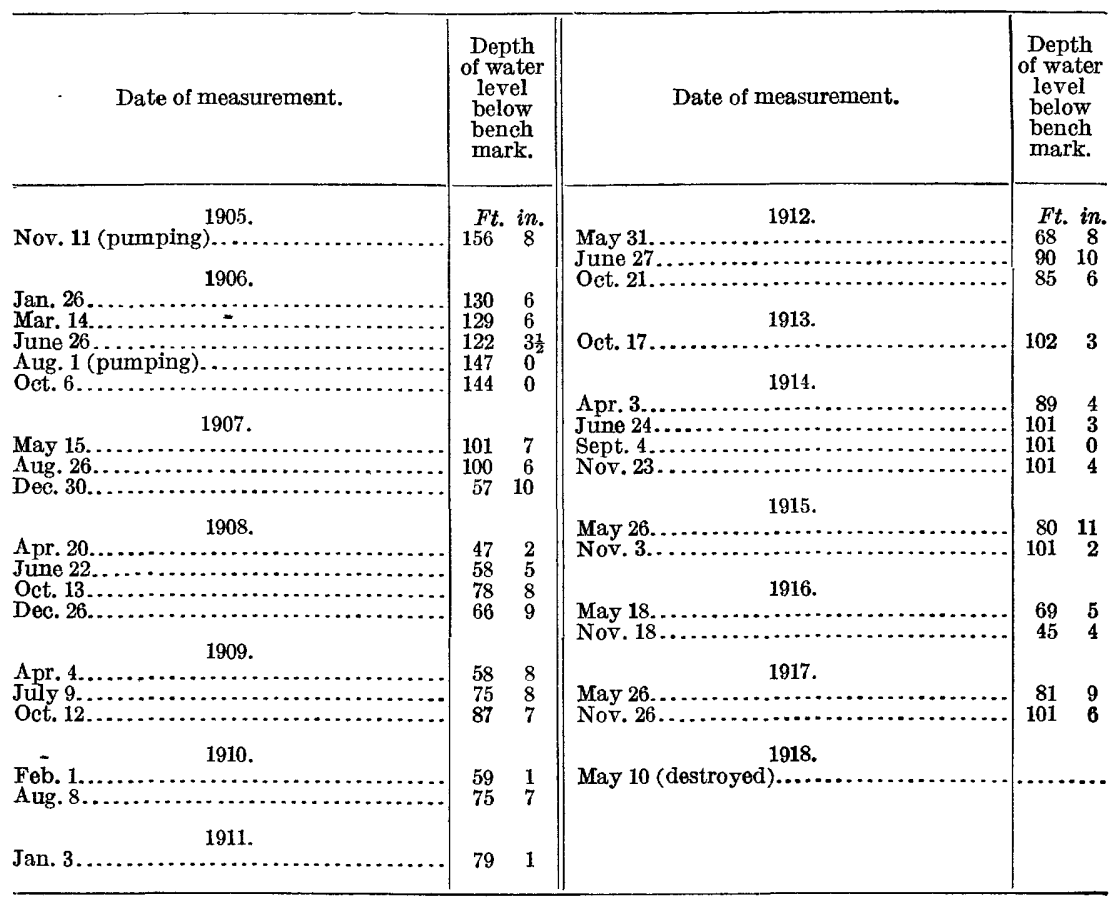


Records of water levels in the valley of southern California-Continued.

57b. Bradley Bros,, three-fourthsi mile southwest of Claremont, Cucamonga quadrangle.

[Bored well, 200 feet deep, 10 inches in diameter; sunk in 1899; altitude of surface, about 1,085 feet above sea level; method of lift, gasoline engine; use, irrigation. Water contains 210 parts per million of dissolved solids. Bench mark: Top casing, 5.0 feet below surface. Well No. 240, Water-Supply Paper 219, p. 149.」

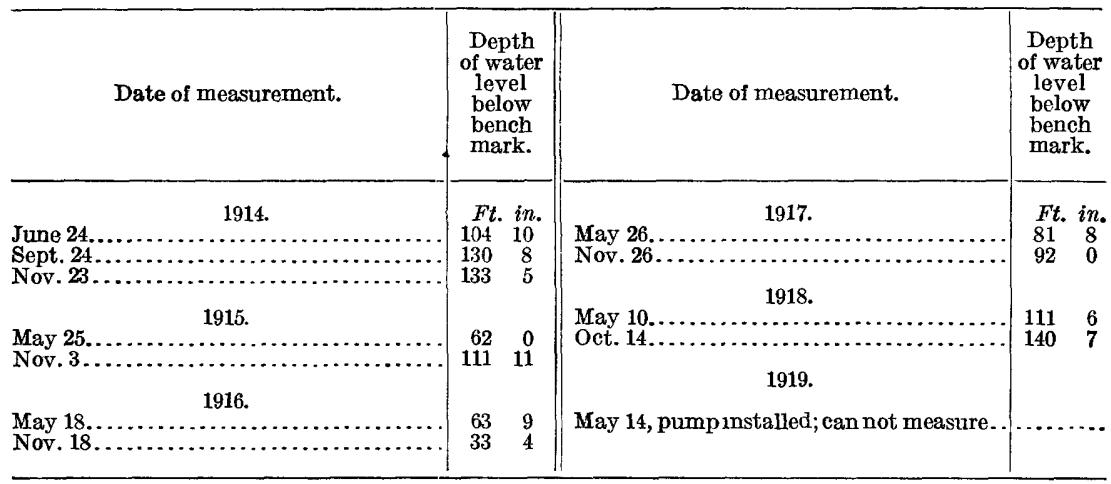

58. H. R. Hopkins (formerly owned by Dr. A. R. Reed), $1 \frac{1}{2}$ miles northeast of Pomona, Cucamonga quadrangle.

[Bored well, 200 feet deep, $9 \frac{1}{2}$ inches in diameter; sunk in 1900; altitude of surface, about 1,010 feet above sea level; method of lift, wind; use, domestic. Bench mark: Top of casing level with surface. Well No. 284, Water-Supply Paper 219, p. 151.]

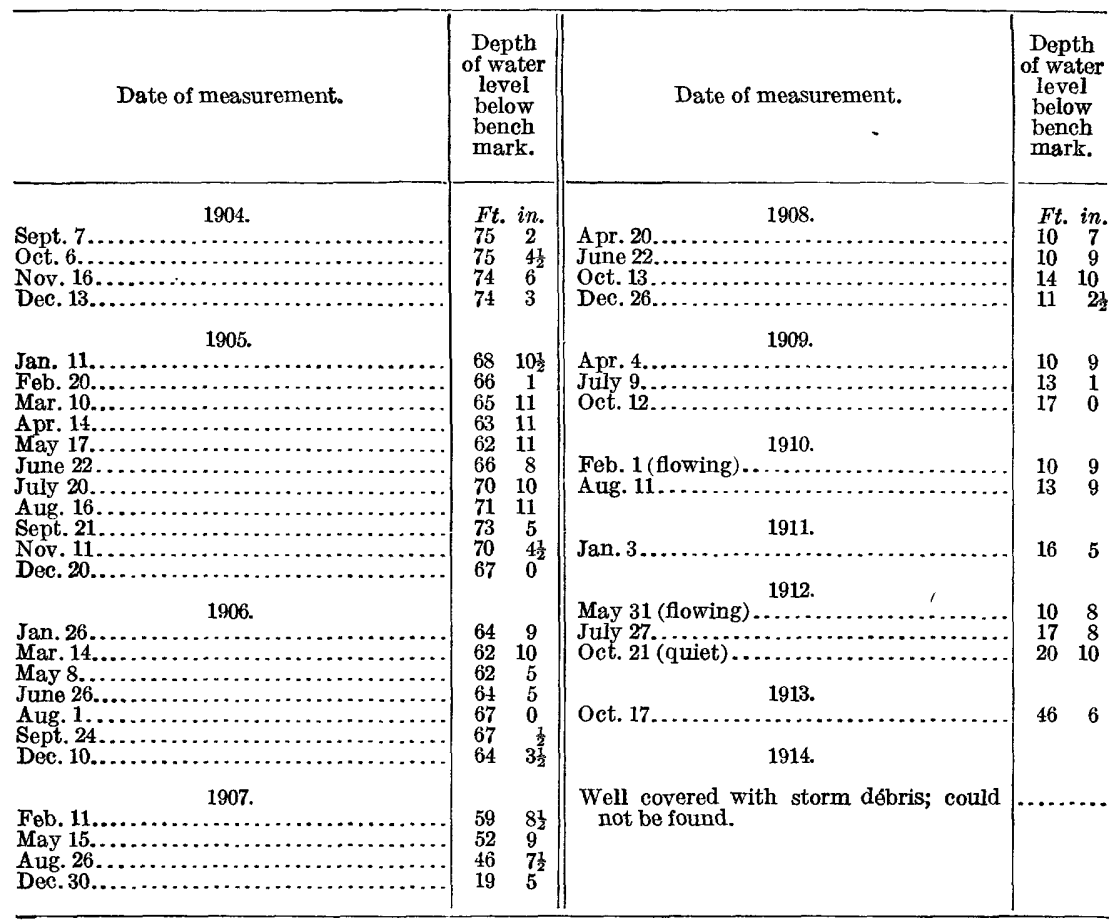


Records of water levels in the valley of southern California-Continued.

58a. Cathcart estate, $1 \frac{1}{2}$ miles northeast of Pomona, Cucamonga quadrangle.

[Bored well-one of a group of 5 wells-300 to 600 feet deep; 12 inches in diameter; sunk about 1886; altitude of surface, about 980 feet above sea level; water not used. Bench mark: Top of concrete casing, 9 inches above surface. Well No. 299, Water-Supply Paper 219, p. 151. Companion well for No. 58, 58b, and 58c. Has been measured in conjunction with observation wells, but record not published heretofore. About 8 or 9 feet below surface these wells How into a common main leading to Chino.]

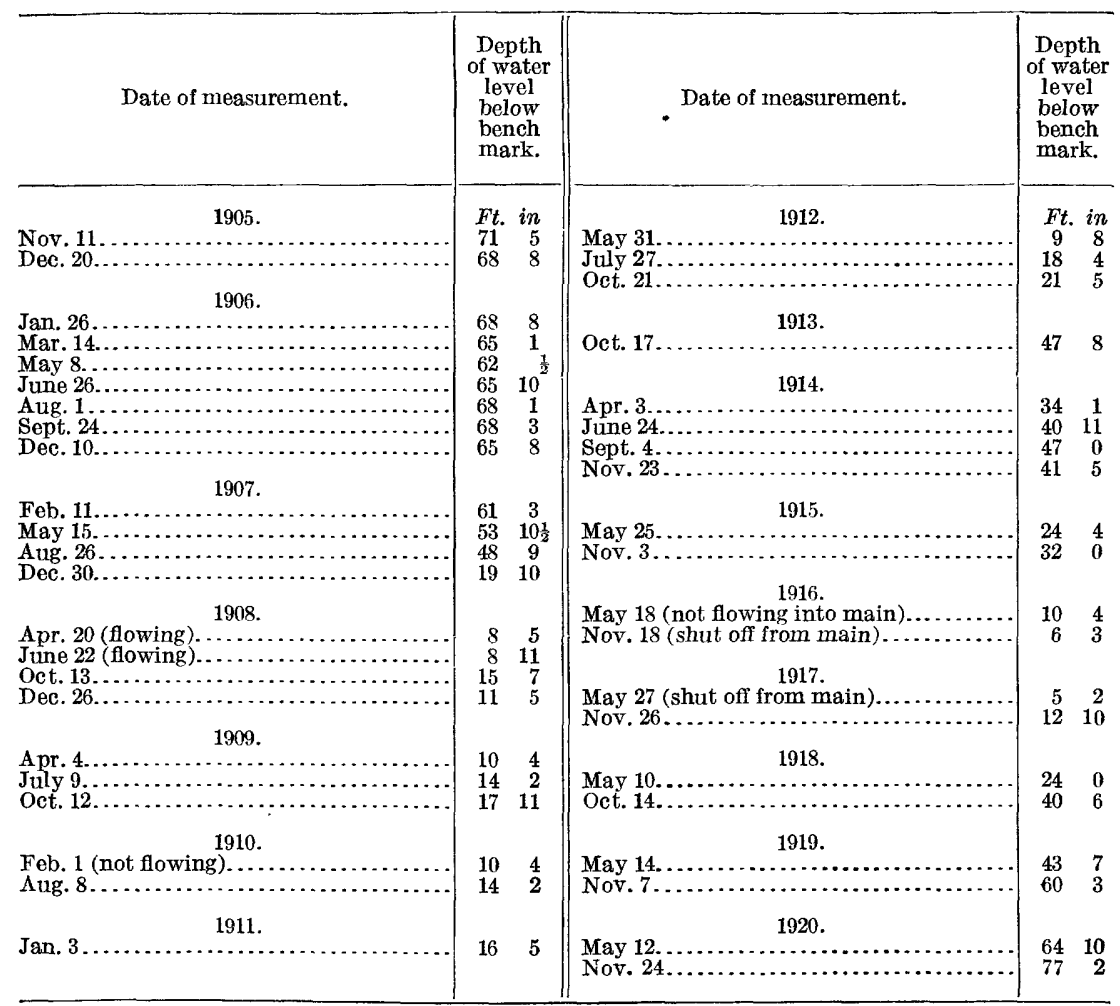


Records of water levels in the valley of southern California-Continued.

58b. Cathcart estate, $1 \frac{1}{2}$ milles northeast of Pomona, Cucamonga quadrangle.

[Bored well-one of a group of 5 wells-300 to 600 feet deep; 12 inches, diameter; sunk about 1885; altitude of surface, about 980 feet above sea level; water not used. Bench mark: Top of concrete casing, 1 foot, 5 inches above surface. Wells No. 299, Water-Supply Paper 219, p. 151. Lucated 75 feet east of No. 58a. See remarks on No. 58a.]

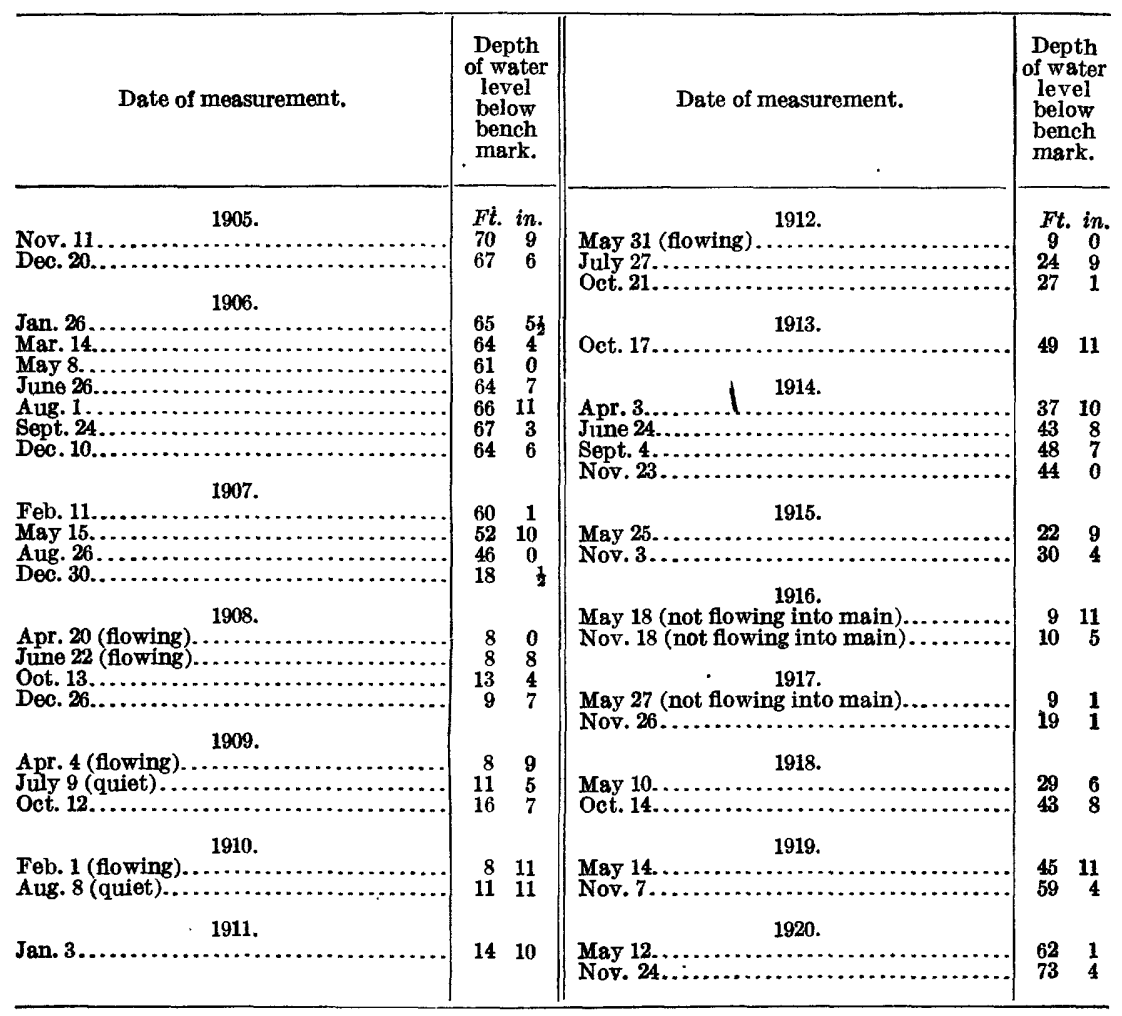

$1820^{\circ}-21$-WSP 468 
Records of water levels in the valley of southern California-Continued.

58c. Cathcart estate, $1 \frac{1}{2}$ miles northeast of Pomona, Cucamonga quadrangle.

[Bored well, one of a group of five wells, 300 to 600 feet deop, 12 inches in diameter; altitude of surface, about 980 feet above sea level; water not used. Bench mark: Top of concrete casing 1 foot 3 inches above surface. Well No. 299, Water-Supply Paper 219, p. 151. Located 75 feet east of No. 58b. See remarks on No. $58 \mathrm{a}$.]

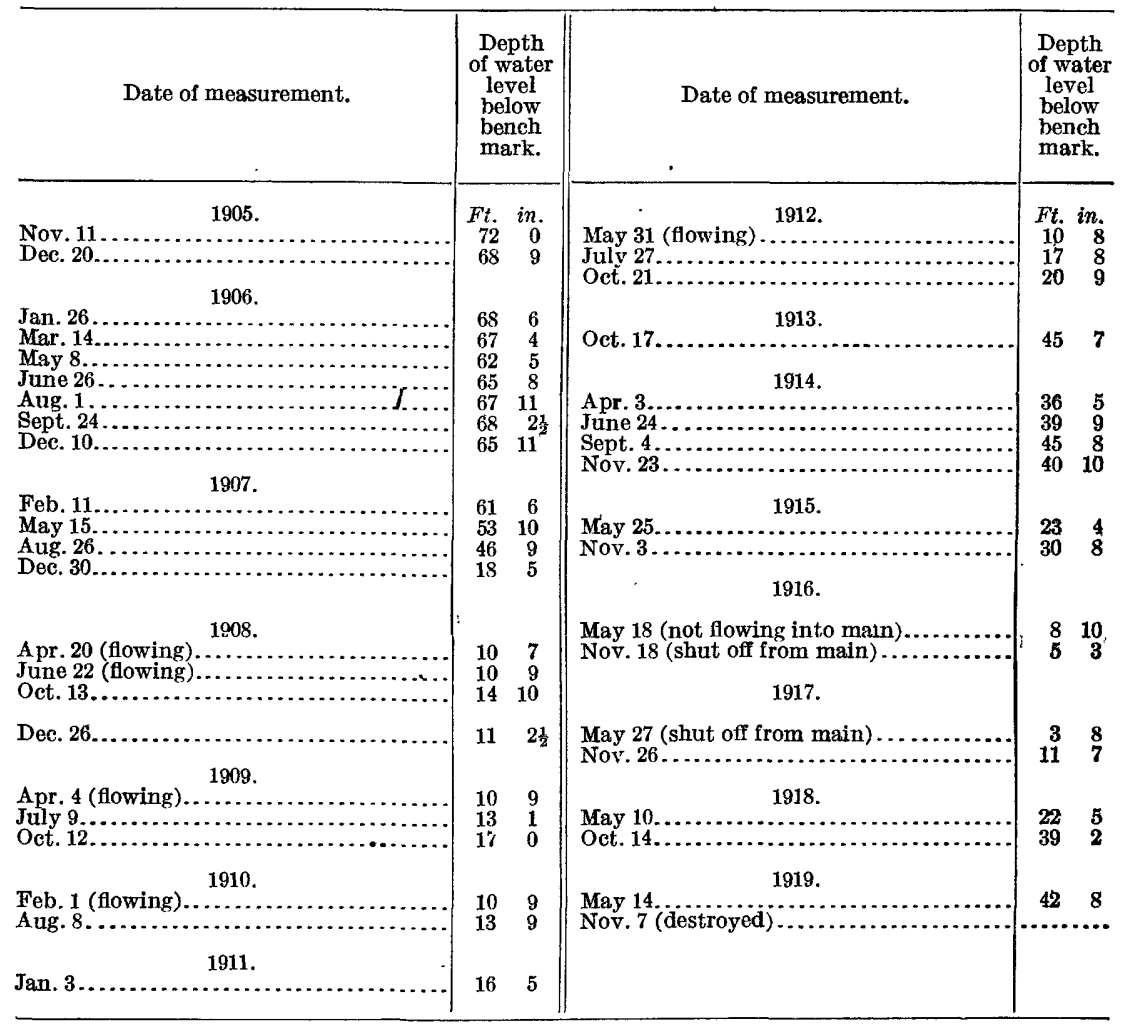

59. B. Linastruth, Pomona, Pomona quadrangle.

[Bench mark not known.]

\begin{tabular}{|c|c|c|c|}
\hline Date of measurement. & $\begin{array}{c}\text { Depth } \\
\text { of water } \\
\text { level } \\
\text { below } \\
\text { bench } \\
\text { mark. }\end{array}$ & Date of measurement. & $\begin{array}{c}\text { Depth } \\
\text { of water } \\
\text { level } \\
\text { below } \\
\text { bench } \\
\text { mark. }\end{array}$ \\
\hline $\begin{array}{c}1904 . \\
\text { Dec. } 14 \ldots \ldots \ldots \ldots \ldots \ldots \ldots \ldots \ldots \ldots \ldots \ldots \ldots \\
1905 .\end{array}$ & $\begin{array}{rr}\text { Ft. } & \text { in. } \\
\mathrm{Q0} & \mathbf{6} \frac{1}{2}\end{array}$ & 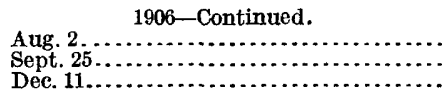 & $\begin{array}{rr}F t . & \text { in. } \\
95 & 6 \\
96 & 0 \\
95 & 2\end{array}$ \\
\hline 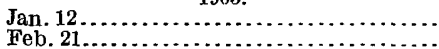 & $\begin{array}{ll}90 & 9 \\
91 & 1\end{array}$ & 1907. & \\
\hline Apr, 15 & 915 & Feb. $11 \ldots \ldots \ldots \ldots \ldots \ldots$ & 95 \\
\hline (1) & $6 \frac{1}{2}$ & May $15 \ldots \ldots \ldots \ldots$ & 93 \\
\hline June $22, \ldots \ldots \ldots \ldots$ & 920 & Aug. 26.................. & 93 \\
\hline July $21, \ldots \ldots \ldots$ & $92 \quad 10 \frac{1}{2}$ & 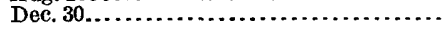 & 91 \\
\hline $\begin{array}{l}\text { Sept, } 20 \\
\text { Nov. } 12, \ldots, 1\end{array}$ & $\begin{array}{ll}93 & 6 \\
93 & 4\end{array}$ & chen & \\
\hline Dec. $21 . . .1 . . .1$. & 9306 & Apr. $21 \ldots \ldots \ldots \ldots \ldots \ldots \ldots \ldots \ldots$ & $\begin{array}{ll}90 & 2 \\
91 & 0\end{array}$ \\
\hline 1906 & & Oct. 13$\}_{\text {well closed }}$ engine installed ...... & $\ldots . . . . .$. \\
\hline $\begin{array}{l}\text { Mar. } 15 \ldots \ldots \ldots \ldots \ldots \ldots \ldots \ldots \\
\text { June } 27, \ldots \ldots \ldots \ldots \ldots \ldots \ldots\end{array}$ & $\begin{array}{ll}92 & 6 \\
93 & 6\end{array}$ & & \\
\hline
\end{tabular}


Records of water levels in the valley of southern California-Continued.

59a. Mrs. Meyers, Pomona, Pomona quadrangle.

[Bored well, 97 feet deep, $9 \frac{1}{2}$ inches in diameter; altitude of surface, about 950 feet above sea level; method of lift, wind; use, domestic. Bench mark: Top of casing, 1 foot 6 inches above surface. Well No. 261 , Water-Supply Paper 219, p. 160 . Has been measured in conjunction with observation wells, but record not published heretofore.]

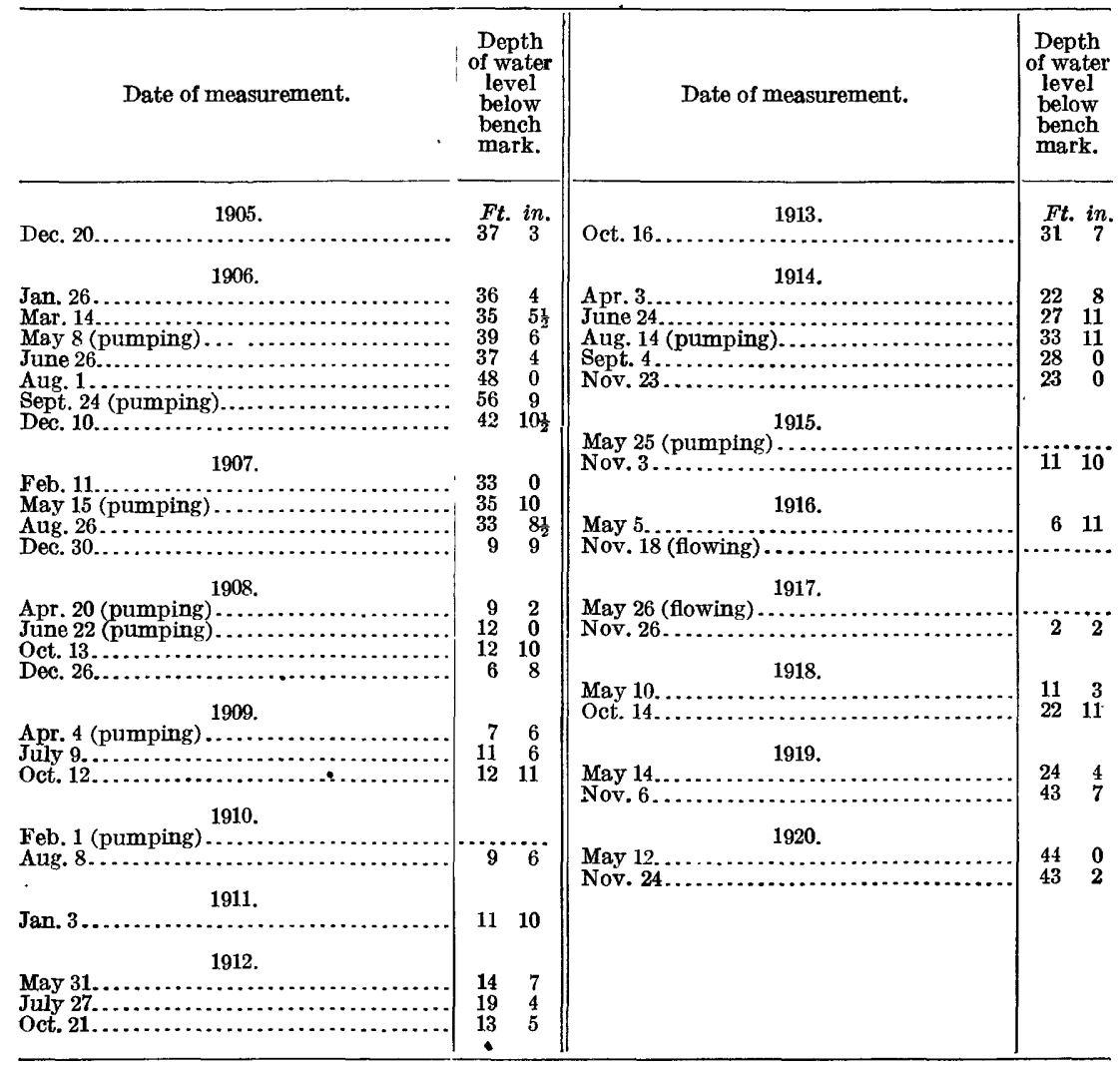

60. J. J. White, Pomona, Cucamonga quadrangle.

[Bored well, 67 feet deep, 7 inches in diameter; sunk in 1884; altitude of surface, about 830 feet above sea level; method of lift, wind; use, domestic. Bench mark not known. Well No. 201, Water-Supply Paper 219, p. 147.]

\begin{tabular}{|c|c|c|c|}
\hline Date of measurement. & $\begin{array}{l}\text { Depth } \\
\text { of water } \\
\text { level } \\
\text { below } \\
\text { bench } \\
\text { mark. }\end{array}$ & Date of measurement. & $\begin{array}{l}\text { Depth } \\
\text { of water } \\
\text { level } \\
\text { below } \\
\text { bench } \\
\text { mark. }\end{array}$ \\
\hline 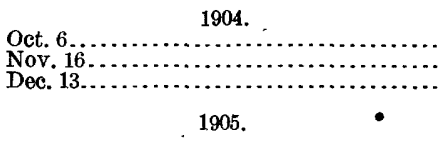 & $\begin{array}{ll}\text { Ftt. } & \text { in. } \\
58 & 9 \frac{1}{2} \\
60 & 3 \\
60 & 6 \frac{1}{2}\end{array}$ & 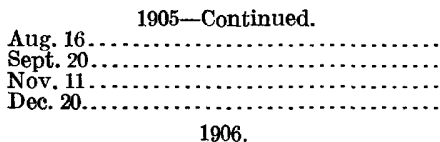 & $\begin{array}{cr}F t \text {. in. } \\
61 & 6 \\
61 & 10 \\
62 & 4 \\
62 & 5\end{array}$ \\
\hline 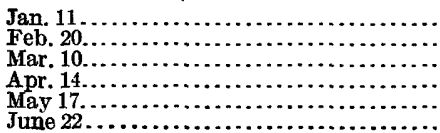 & $\begin{array}{lc}60 & 10 \\
61 & 1 \frac{1}{2} \\
61 & 4 \frac{1}{2} \\
60 & 8 \\
60 & 11 \\
61 & 1\end{array}$ & 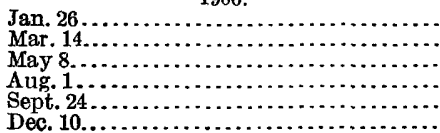 & $\begin{array}{lc}62 & 3 \frac{1}{2} \\
63 & 1 \\
63 & 1 \frac{1}{2} \\
63 & 5 \\
64 & 41 \\
64 & 11\end{array}$ \\
\hline
\end{tabular}


Records of water levels in the valley of southern California-Continued.

60. J. J. White-Continued.

\begin{tabular}{|c|c|c|c|}
\hline Date of measurement. & $\begin{array}{l}\text { Depth } \\
\text { of water } \\
\text { level } \\
\text { below } \\
\text { bench } \\
\text { mark. }\end{array}$ & Date of measurement. & $\begin{array}{l}\text { Depth } \\
\text { of water } \\
\text { level } \\
\text { below } \\
\text { bench } \\
\text { mark. }\end{array}$ \\
\hline 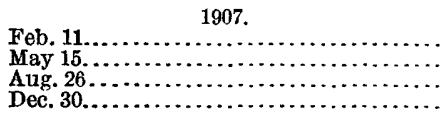 & $\begin{array}{ll}\text { Ft. } & \text { in } \\
63 & 5 \\
65 & 4 \\
63 & 5 \frac{1}{2} \\
63 & 0\end{array}$ & 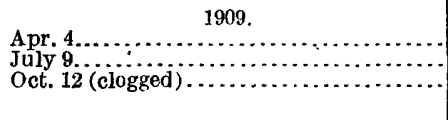 & $\begin{array}{lc}\text { Ft. } & \text { in. } \\
62 & 6 \\
62 & 7 \\
\ldots\end{array}$ \\
\hline 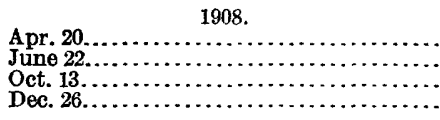 & $\begin{array}{ll}62 & 9 \\
62 & 9 \\
63 & 2 \\
62 & 9\end{array}$ & & \\
\hline
\end{tabular}

61. F. R. Allen (former owners, Mrs. Tieg, W. J. Huebsch), $1 \frac{1}{2}$ miles southeast of Pomona, Cucamonga quadrangle.

[Bored well, 341 feet deep, 10 inches in diameter; altitude of surface, about 835 feet above sea level; water not used. Bench mark: Top of 10 by 12 timber over curb, 1 foot 2 inches above surface. Well No. 177, Water-Supply Paper 219, p. 147.]

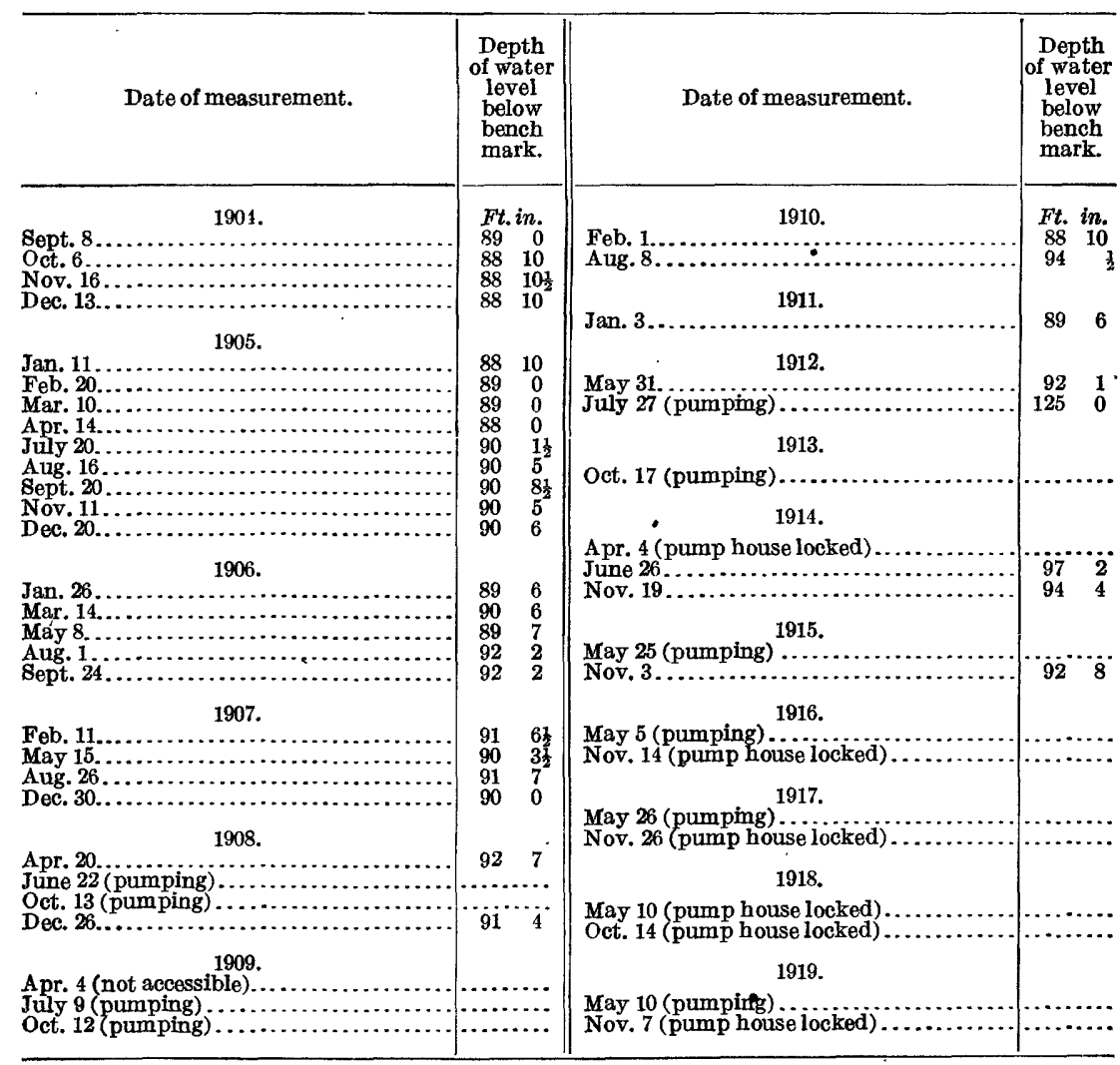


Records of water levels in the valley of southern California-Continued.

62. Lee \& Gilmore (former owners, R. Reimers, H. Arnold), $2 \frac{1}{2}$ miles southeast of Pomona, Cucamonga quadrangle.

[Bored well, 65 feet deep, 7 inchesin diameter; sunk in 1894; altitude of surface, about 770 feet above sea level: method of lift, wind; use, domestic. Bench mark: Top of casing, 3 inches above surface. Well No. 181, Water-Supply Paper 219, p. 147.]

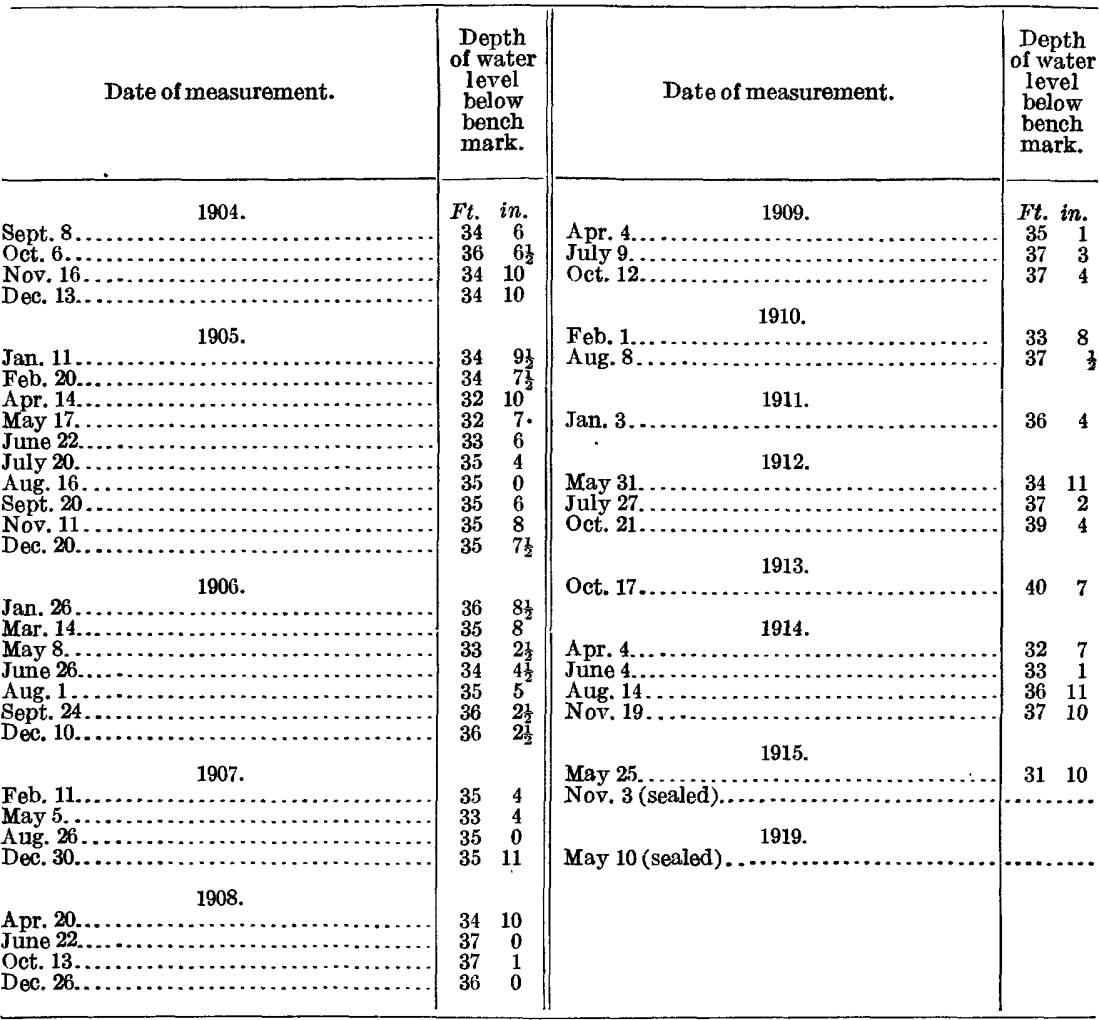

62a. Lee \& Gilmore, $2 \frac{1}{2}$ miles southeast of Pomona, Cucamonga quadrangle.

[Companion well about 500 feet north of No. 62 . Bench mark: Top of 10 by 12 timber over pump pit, 1 foot 2 inches above surface.]

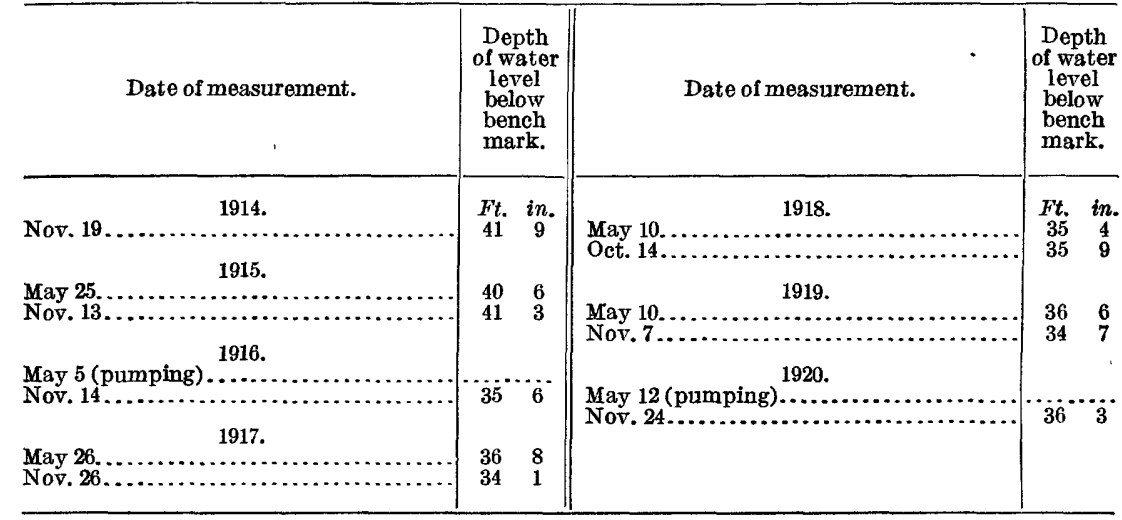




\section{Records of water levels in the valley of southern California-Continued.}

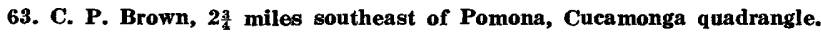

[Bored well, 160 feet deep, $9 \frac{1}{2}$ inches in diameter; altitude of surface about 730 feet above sea level; water not used. Bench mark not known. Well No. 214, Water-Supply Paper 219, p. 148.]

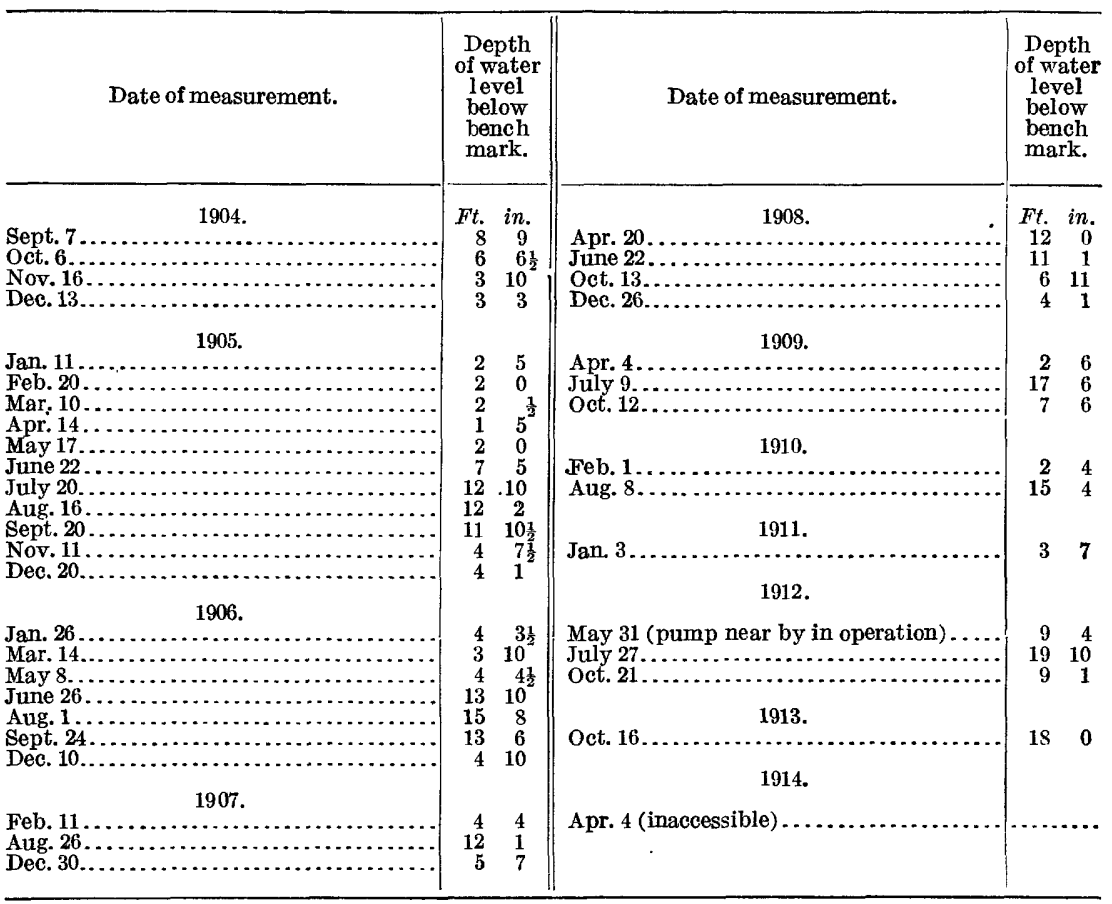

63a. E. G. Nelson, Bellfleur ranch, 11 miles east of Chino, Cucamonga quadrangle.

[Companion well for No. 63. Four-inch well, 165 feet deep; method of lift, wind; use, domestic; generally flows during winter. Bench mark: Top of casing, 2.0 feet above surface.]

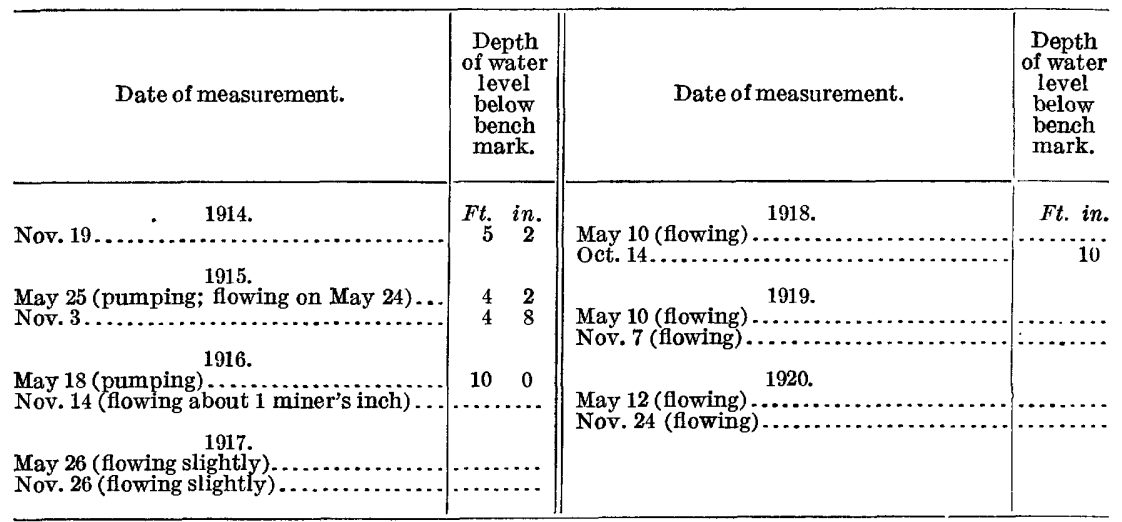


Records of water levels in the valley, of southern California-Continued.

64. Mr. Haley, one-fourth mile west of San Bernardino, San Bernardino quadrangle.

[Bench mark not known.]

\begin{tabular}{|c|c|c|c|}
\hline Date of measurement. & $\begin{array}{l}\text { Depth } \\
\text { of water } \\
\text { level } \\
\text { below } \\
\text { bench } \\
\text { mark. }\end{array}$ & Date of measurement. & $\begin{array}{l}\text { Depth } \\
\text { of water } \\
\text { level } \\
\text { below } \\
\text { bench } \\
\text { mark. }\end{array}$ \\
\hline 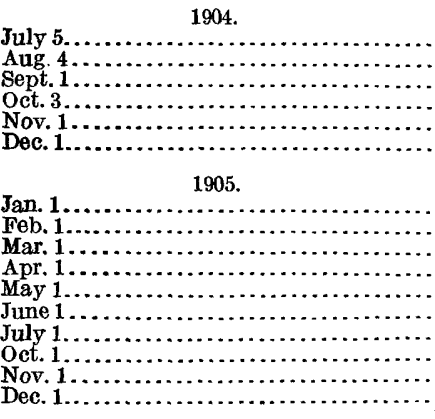 & $\begin{array}{rr}\text { Ft. } & \text { in. } \\
36 & 7 \\
38 & 2 \\
37 & 3 \\
37 & 1 \\
38 & 11 \\
39 & 10 \\
& \\
37 & 2 \\
33 & 0 \\
30 & 7 \\
29 & 9 \\
30 & 1 \\
37 & 7 \\
39 & 0 \\
40 & 6 \\
36 & 10 \\
33 & 8\end{array}$ & 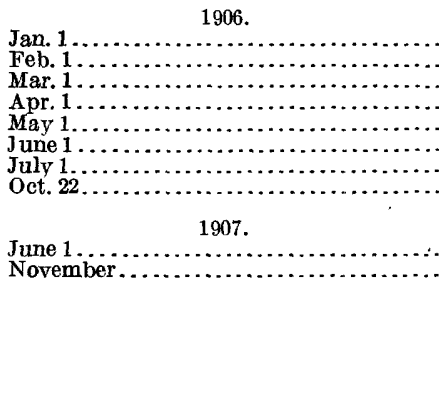 & $\begin{array}{rr}\text { Ft. } & \text { in. } \\
33 & 8 \\
33 & 0 \\
32 & 0 \\
31 & 4 \\
36 & 6 \\
35 & 8 \\
38 & 5 \\
30 & 5 \\
& \\
& \\
9 & 2 \\
14 & 3\end{array}$ \\
\hline
\end{tabular}

65. C. W. Rogers, 1 mile east of Colton, San Bernardino quadrangle.

[Bench mark not known.]

\begin{tabular}{|c|c|c|c|}
\hline Date of measurement. & $\begin{array}{c}\text { Depth } \\
\text { of water } \\
\text { level } \\
\text { below } \\
\text { bench } \\
\text { mark. }\end{array}$ & Date of measurement. & $\begin{array}{l}\text { Depth } \\
\text { of water } \\
\text { l evel } \\
\text { below } \\
\text { bench } \\
\text { mark. }\end{array}$ \\
\hline 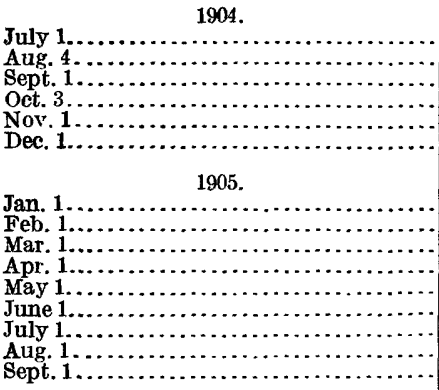 & $\begin{array}{rr}F t . & \text { in. } \\
15 & 8 \\
18 & 1 \\
19 & 8 \\
21 & 0 \\
20 & 2 \\
21 & 10 \\
& \\
17 & 6 \\
12 & 5 \\
7 & 6 \\
5 & 5 \\
5 & 6 \\
6 & 5 \\
9 & 4 \\
12 & 9 \\
15 & 11\end{array}$ & 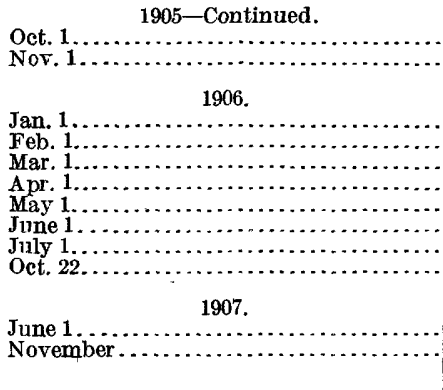 & $\begin{array}{rr}14 & 4 \\
12 & 7 \\
8 & 4 \\
5 & 5 \\
6 & 0 \\
5 & 11 \\
6 & 10 \\
17 & 3\end{array}$ \\
\hline
\end{tabular}


Records of water levels in the valley of southern California-Continued.

66. Riverside Water Co., 2 miles east of Colton, San Bernardino quadrangle.

[Bench mark not known.]

\begin{tabular}{|c|c|c|c|}
\hline Date of measurement. & $\begin{array}{l}\text { Depth } \\
\text { of water } \\
\text { l evel } \\
\text { below } \\
\text { bench } \\
\text { mark. }\end{array}$ & Date of measurement. & $\begin{array}{l}\text { Depth } \\
\text { of water } \\
\text { level } \\
\text { below } \\
\text { bench } \\
\text { mark. }\end{array}$ \\
\hline 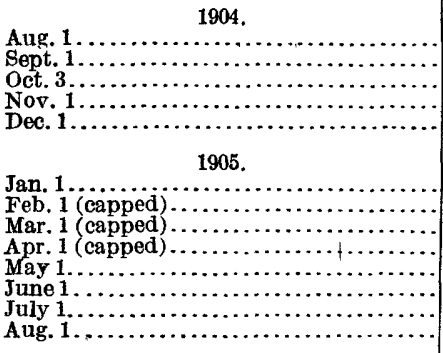 & \begin{tabular}{|cc} 
Ft. & in \\
3 & 8 \\
4 & 5 \\
5 & 2 \\
4 & 5 \\
5 & 2 \\
\\
\\
5 & 2 \\
$\cdots$ & 2 \\
\hdashline & $\cdots$ \\
\hdashline & 2 \\
5 & 2 \\
7 & 6 \\
5 & 2
\end{tabular} & 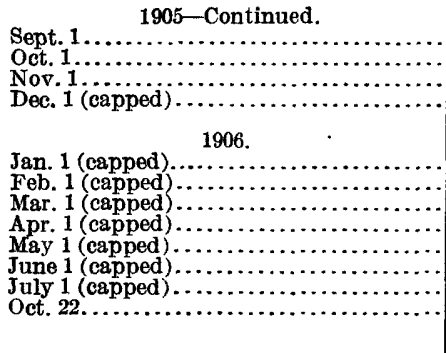 & 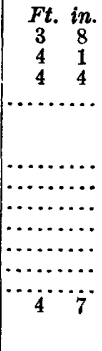 \\
\hline
\end{tabular}

67. Riverside Water Co., Third and Waterman streets, San Bernardino, San Bernardino quadrangle.

[Bench mark not known.]

\begin{tabular}{|c|c|c|c|}
\hline Date of measurement. & $\begin{array}{l}\text { Depth } \\
\text { of water } \\
\text { level } \\
\text { below } \\
\text { bench } \\
\text { mark. }\end{array}$ & Date of measurement. & $\begin{array}{c}\text { Depth } \\
\text { of water } \\
\text { level } \\
\text { below } \\
\text { bench } \\
\text { mark. }\end{array}$ \\
\hline 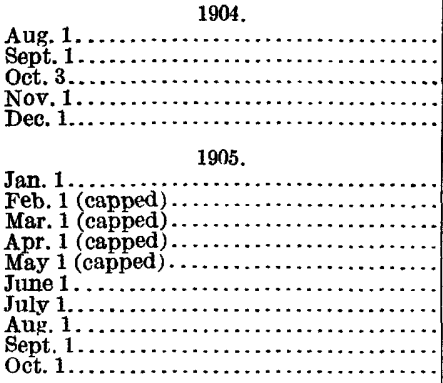 & \begin{tabular}{|cc} 
Ft. & in. \\
121 & 6 \\
121 & 6 \\
112 & 6 \\
116 & 0 \\
116 & 4 \\
& \\
117 & 0 \\
$\cdots \cdots \cdots$ & $\cdots$ \\
$\cdots \cdots \cdots$ \\
\hdashline 117 & 0 \\
118 & 5 \\
116 & 8 \\
111 & 7 \\
115 & 0
\end{tabular} & 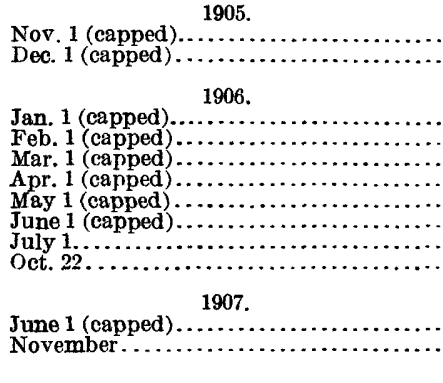 & 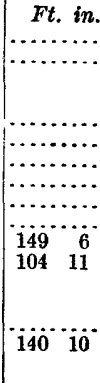 \\
\hline
\end{tabular}


Records of water levels in the valley of southern California-Continued.

68. N. B. Hinkley estate, three-fourths mile west of Bryn Mawr, Redlands quadrangle.

[Bench mark not known.]

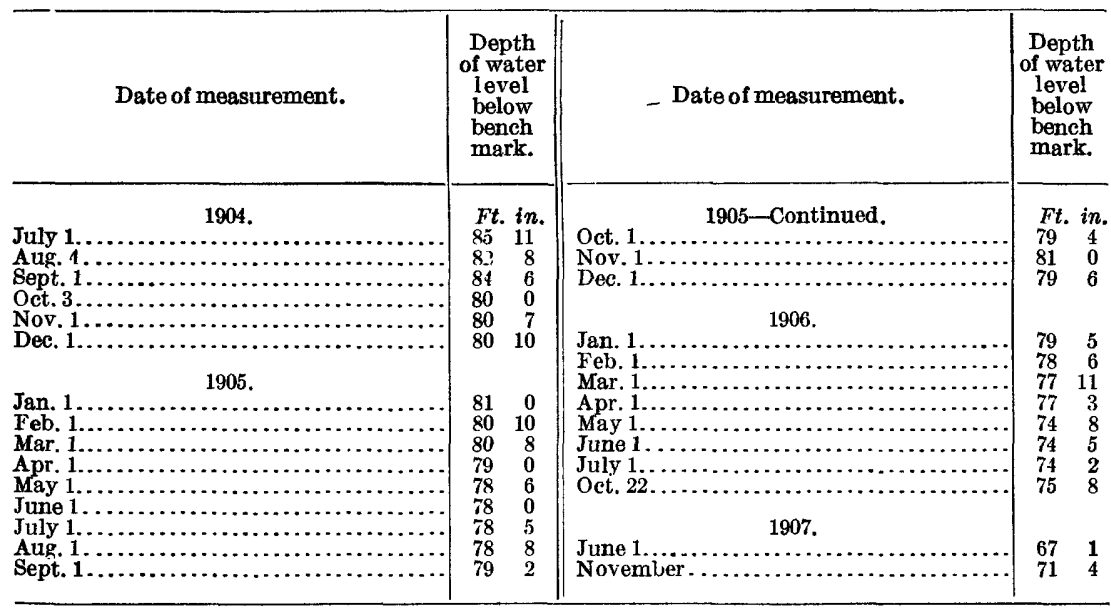

69. County well, $2 \frac{1}{2}$ miles south of Alessandro, Elsinore quadrangle.

[Bench mark: Top of casing, 2 feet above \$urface. Well No. 10, Water-Supply Paper 429, p. 53.]

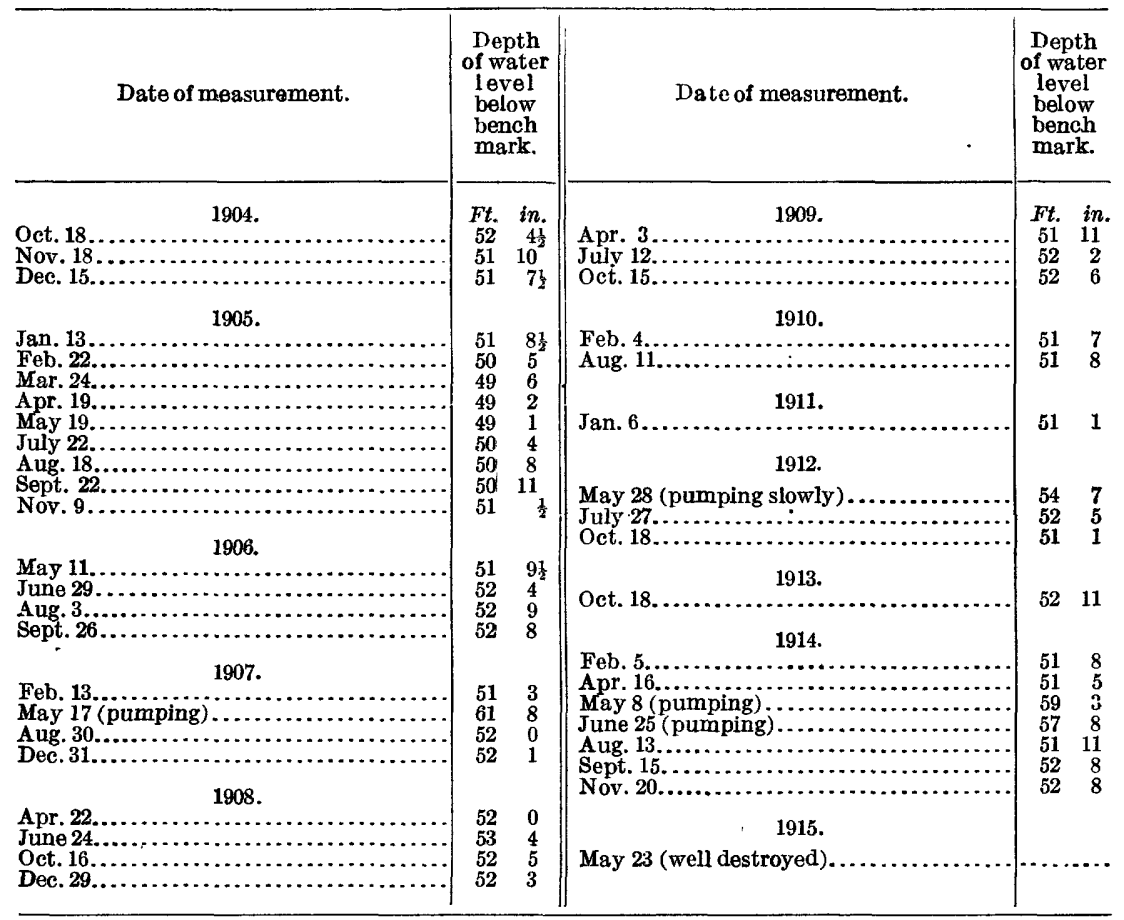


Records of water levels in the valley of southern California-Continued.

69a. J. W. Lancaster, $2 \frac{1}{2}$ miles south of Alessandro, Elsinore quadrangle.

[Well, 93feet deep, 12-inch casing; small gasoline pumping plant; use, irrigation and domestic; situated 250 feet southeast of No. 69 . Bench mark: Top of casing, 1 foot 6 inches above surface.]

\begin{tabular}{|c|c|c|c|}
\hline Date of measurement. & $\begin{array}{l}\text { Depth } \\
\text { of water } \\
\text { level } \\
\text { below } \\
\text { bench } \\
\text { mark. }\end{array}$ & Date of measurement. & $\begin{array}{l}\text { Depth } \\
\text { of water } \\
\text { level } \\
\text { below } \\
\text { bench } \\
\text { mark. }\end{array}$ \\
\hline 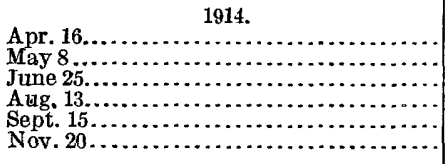 & $\begin{array}{lr}\text { Fi. } & \text { in } \\
46 & 8 \\
46 & 10 \\
47 & 9 \\
47 & 11 \\
48 & 2 \\
47 & 11\end{array}$ & 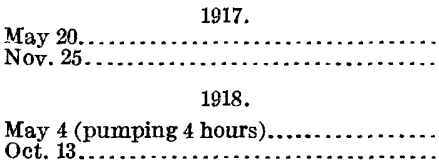 & $\begin{array}{ll}\text { Ft. } & \text { in } \\
47 & 7 \\
47 & 1\end{array}$ \\
\hline 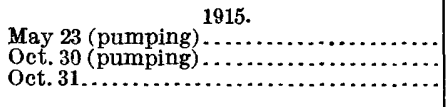 & $\begin{array}{rr}57 & 11 \\
53 & 6 \\
47 & 9\end{array}$ & $\begin{array}{l}1919 . \\
\text { May } 10 \text { (pumping) } \ldots \ldots \ldots \ldots \ldots \ldots \ldots \ldots \ldots \\
\text { May } 11 \text { (pumping) } \ldots \ldots \ldots \ldots \ldots \ldots \ldots \ldots \ldots \ldots \\
\text { Oct. } 12 . \ldots \ldots \ldots \ldots \ldots \ldots \ldots \ldots \ldots \ldots \ldots \ldots \ldots\end{array}$ & 4510 \\
\hline 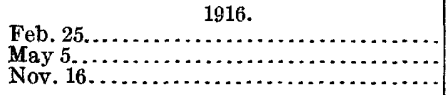 & $\begin{array}{rr}46 & 5 \\
48 & 6 \\
47 & 10\end{array}$ & $\begin{array}{c}1920 . \\
\text { May } 18 \text { (pumping } 3 \text { hours) } \ldots \ldots \ldots \ldots \ldots \ldots \\
\text { Oct. } 16 \ldots \ldots \ldots \ldots \ldots \ldots \ldots \ldots \ldots \ldots \ldots \ldots \ldots \ldots \ldots \ldots\end{array}$ & $\begin{array}{rr}64 & 10 \\
45 & 5\end{array}$ \\
\hline
\end{tabular}

70. Edward Poorman, 4 miles northeast of Perris, Elsinore quadrangle.

[Bench mark: Top of casing, 2.0 feet above surface. Well No. 12, Water-Supply Paper 429, p. 54.]

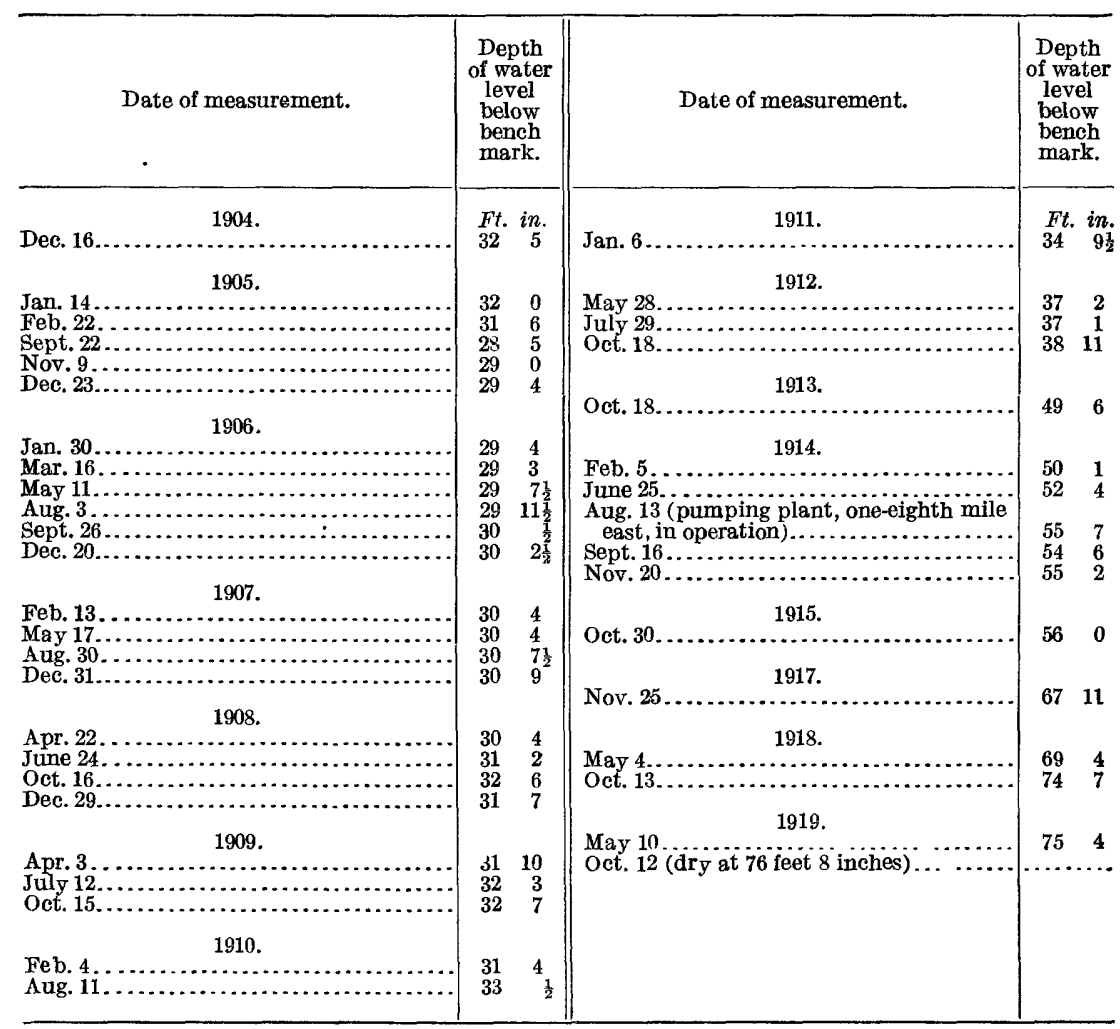


Records of water levels in the valley of southern California-Continued.

71. C. S. Phillips (formerly owned by C. Lossman), $2 \frac{1}{2}$ miles north of Perris, Elsinore quadrangle.

[Bench mark not known. Well No. 24, Water-Supply Paper 429, p. 55.]

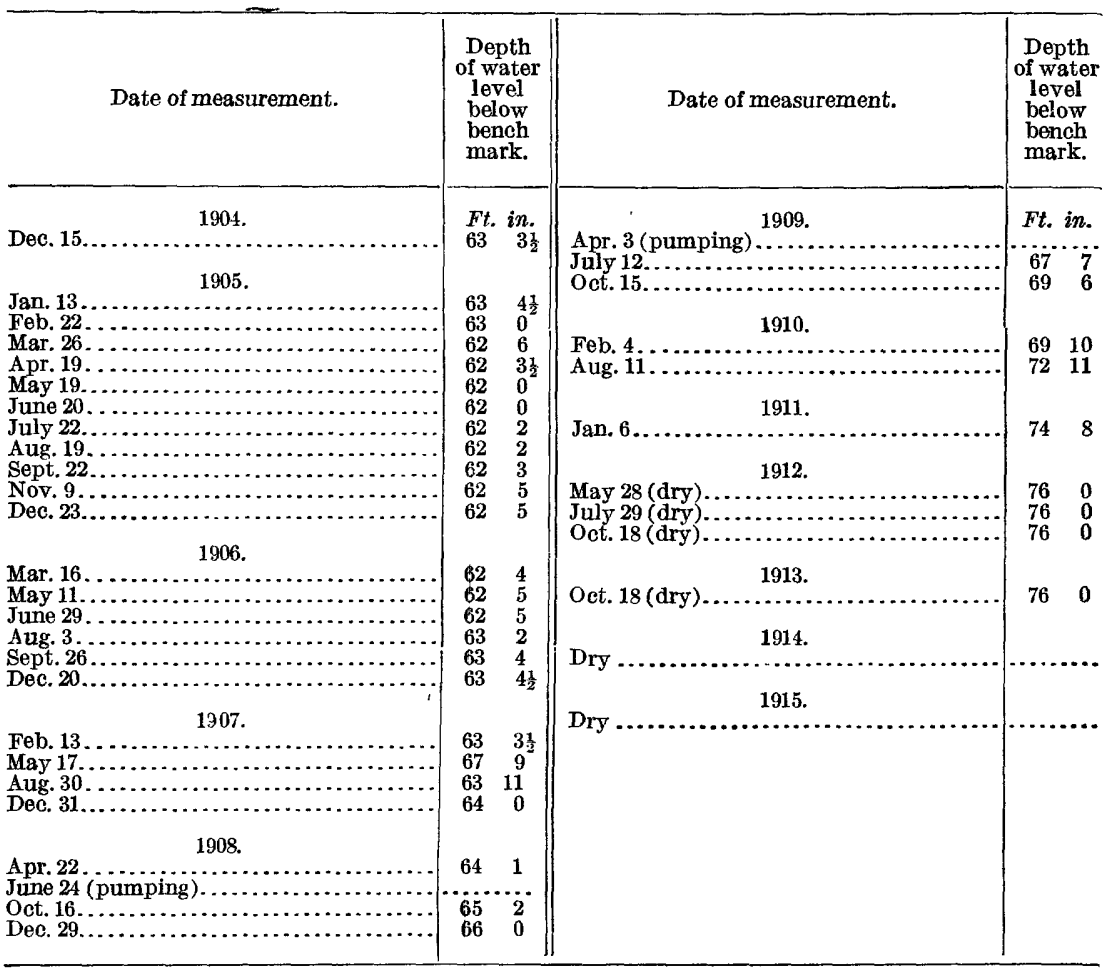

72. Santos Moro (formerly owned by Crawford Carter), Perris, Elsinore quadrangle.

[Bench mark: Top of casing, 2 feet 6 inches above surface. Well No. 30, Water-Supply Paper 429, p. 56.]

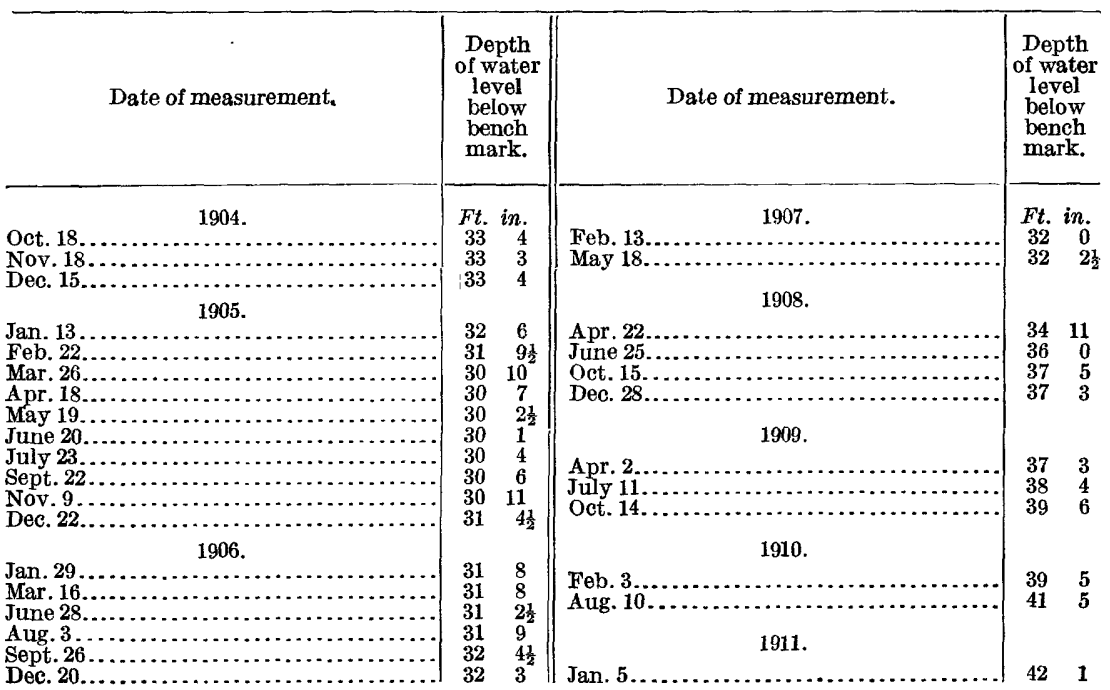


Records of water levels in the valley of southern California-Continued.

72. Santos Moro-Continued.

\begin{tabular}{|c|c|c|c|}
\hline Date of measurement. & $\begin{array}{l}\text { Depth } \\
\text { of water } \\
\text { level } \\
\text { below } \\
\text { bench } \\
\text { mark. }\end{array}$ & Date of measurement. & $\begin{array}{c}\text { Depth } \\
\text { of water } \\
\text { level } \\
\text { below } \\
\text { bench } \\
\text { mark. }\end{array}$ \\
\hline $\begin{array}{l}\text { May } 28 \ldots \ldots \ldots \ldots \ldots \ldots \ldots \ldots \ldots \ldots \ldots \ldots \ldots \ldots \ldots \ldots \ldots \ldots \ldots \ldots \ldots \ldots \\
\text { July } 29 \ldots \ldots \ldots \ldots \ldots \\
\text { Oct. } 18 \text { (pumping slowly for } 3 \text { hours) } \ldots \ldots\end{array}$ & $\begin{array}{lc}\text { Ft. } & \text { in. } \\
45 & 6 \\
47 & 2 \\
55 & 2\end{array}$ & 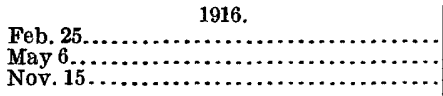 & $\begin{array}{lr}\text { Ft. } & \text { in } \\
55 & 10 \\
54 & 9 \\
55 & 2\end{array}$ \\
\hline Oct. 18................. & $50 \quad 6$ & $\begin{array}{l}\text { May }_{20} \ldots \ldots \ldots \ldots \ldots \ldots \ldots \ldots \ldots \ldots \ldots \ldots \ldots \ldots \ldots \ldots \\
\text { Nov. } 25 \ldots \ldots \ldots \ldots \ldots \ldots \ldots \ldots \ldots \ldots \ldots \ldots\end{array}$ & $\begin{array}{rr}55 & 4 \\
56 & 11\end{array}$ \\
\hline 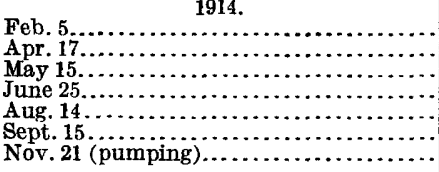 & $\begin{array}{ll}50 & 4 \\
51 & 7 \\
51 & 9 \\
52 & 3 \\
53 & 0 \\
53 & 8 \\
73 & 0\end{array}$ & 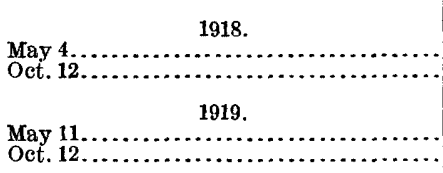 & $\begin{array}{l}55 \\
55\end{array}$ \\
\hline 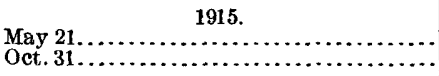 & $\begin{array}{rr}63 & 10 \\
55 & 6\end{array}$ & 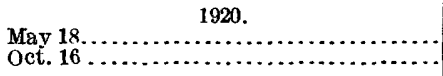 & $\begin{array}{l}57 \\
58\end{array}$ \\
\hline
\end{tabular}

72a. Paul Moro, Perris, Elsinore quadrangle.

[Companion well for No. 72;3 by 3 open curb, 55 feet deep; use, domestic; situated 300 feet north of No. 72 . Bench mark: Top of curb, 0.9 foot above surface.]

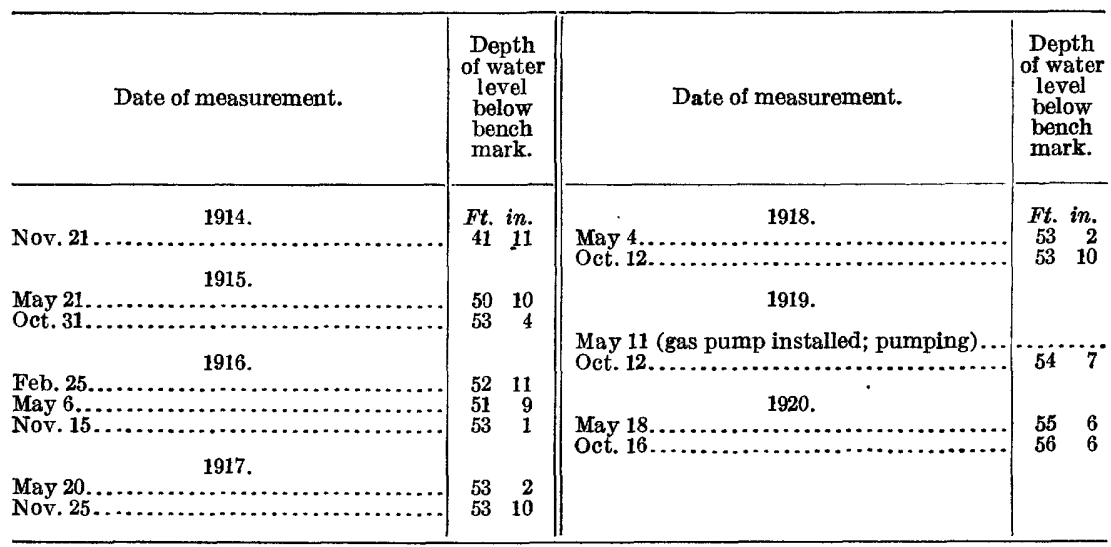


Records of water levels in the valley of southern California-Continued.

73. Mrs. L. R. Harford, $3 \frac{1}{2}$ miles east of Perris, Elsinore quadrangle.

[Bench mark not known. Well No. 34, Water-Supply Paper 429, p. 57.]

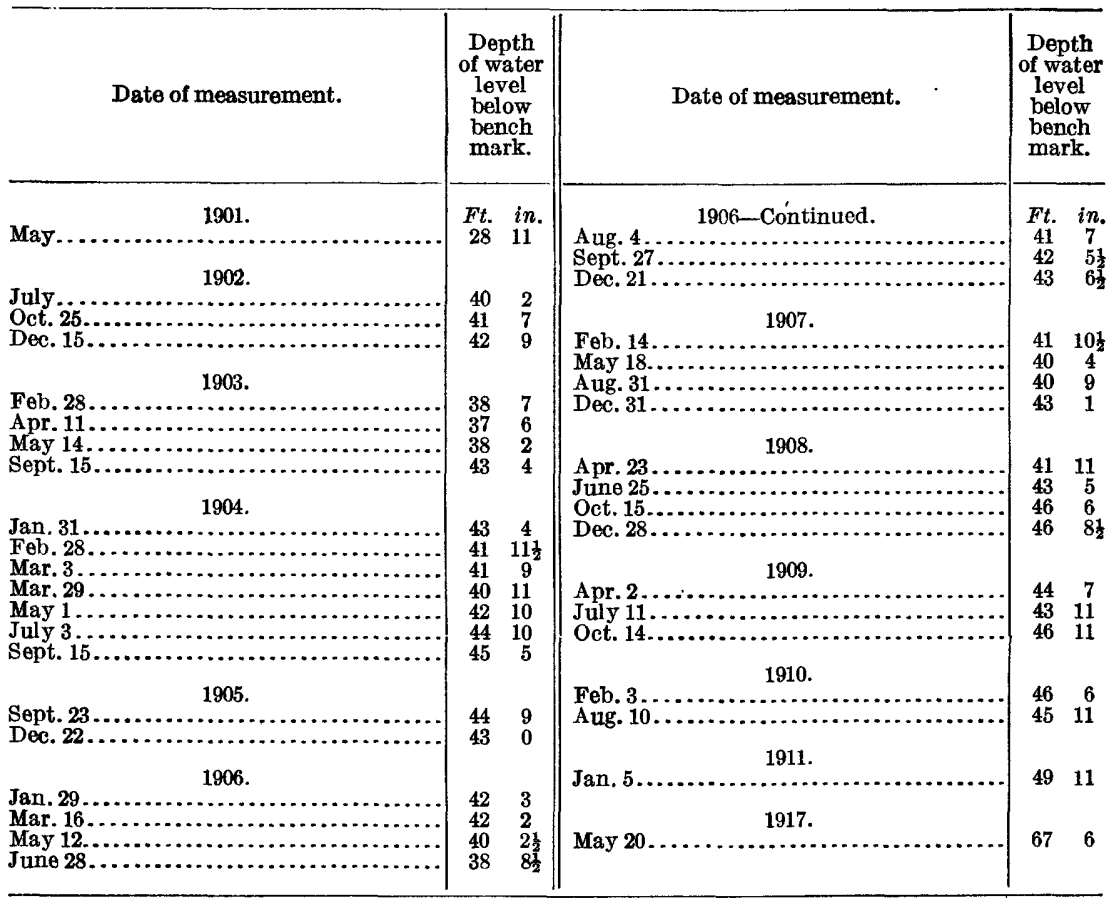

74. E. E. Waters, Ethanac, Elsinore quadrangle.

[Bench mark not known. Well No. 45, Water-Supply Paper 429, p. 59.]

\begin{tabular}{|c|c|c|c|}
\hline Date of measurement. & $\begin{array}{c}\text { Depth } \\
\text { of water } \\
\text { level } \\
\text { below } \\
\text { bench } \\
\text { mark. }\end{array}$ & Date of measurement. & $\begin{array}{l}\text { Depth } \\
\text { of water } \\
\text { level } \\
\text { below } \\
\text { bench } \\
\text { mark. }\end{array}$ \\
\hline 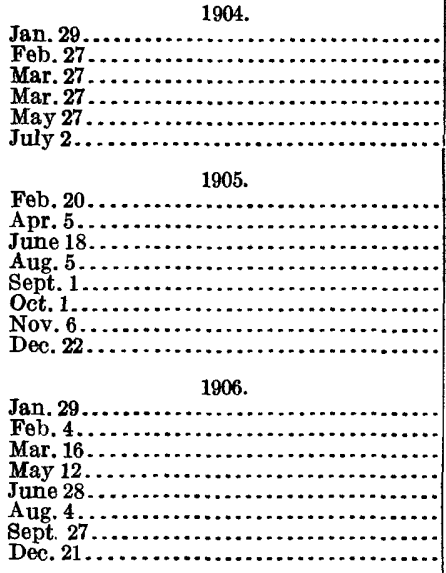 & $\begin{array}{cc}\text { Ft. } & \text { in } \\
44 & 2 \\
41 & 4 \\
40 & 5 \frac{1}{2} \\
43 & 4 \\
41 & 7 \frac{1}{2} \\
46 & 0 \\
& \\
44 & 8 \\
43 & 1 \frac{1}{2} \\
45 & 5 \frac{1}{2} \\
46 & 11 \\
47 & 6 \\
47 & 10 \\
48 & 2 \\
44 & 8 \\
& \\
& \\
42 & 10 \\
42 & 4 \\
42 & 8 \\
41 & 2 \\
44 & 10 \frac{1}{2} \\
45 & 0 \\
47 & 6 \frac{1}{2} \\
45 & 3\end{array}$ & 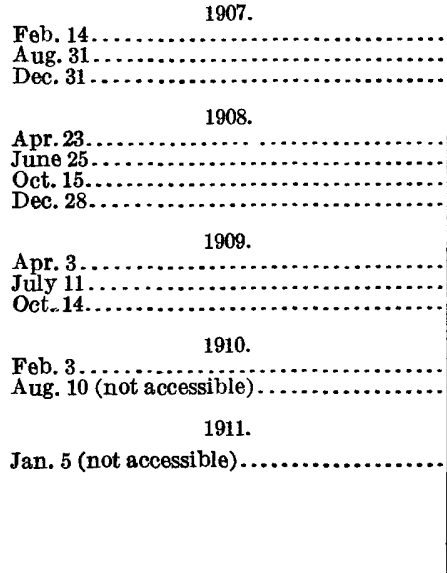 & $\begin{array}{cc}39 & 1 \\
45 & 7 \\
46 & 3 \\
45 & 4 \\
& \\
& \\
48 & 4 \\
53 & 5 \\
55 & 2 \\
& \\
50 & 7 \\
\ldots \ldots \ldots . .\end{array}$ \\
\hline
\end{tabular}


Records of water levels in the valley of southern California-Continued.

75. Temescal Water Co., $1 \frac{1}{2}$ miles west of Ethanac, Elsinore quadrangle.

[Bench mark: Top of casing, 2 feet above surface. Well No. 43, Water-Supply Paper 429, p. 59.]

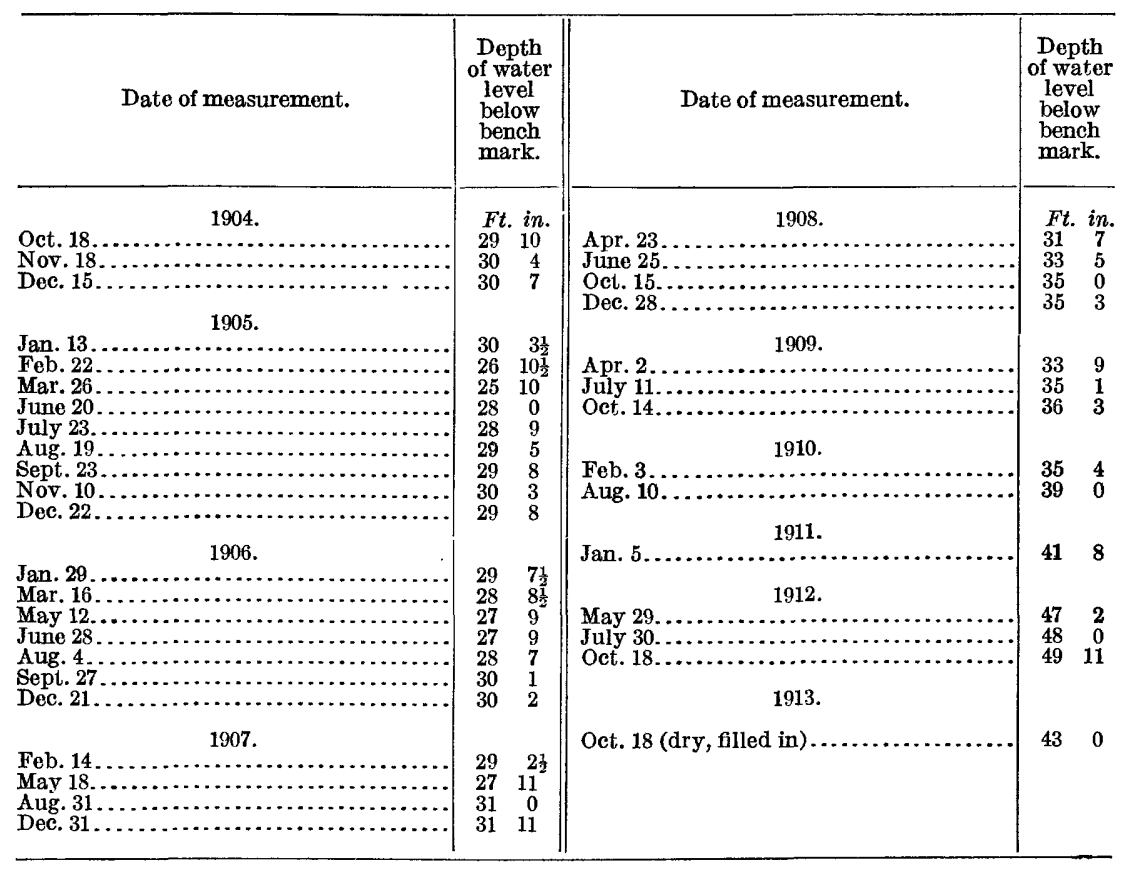

76. Dr. Reese, $2 \frac{1}{1}$ miles south of Perris, Elsinore quadrangle.

[Bench mark: Top of casing, level with surface. Well No. 42, Water-Supply Paper 429, p. 58.]

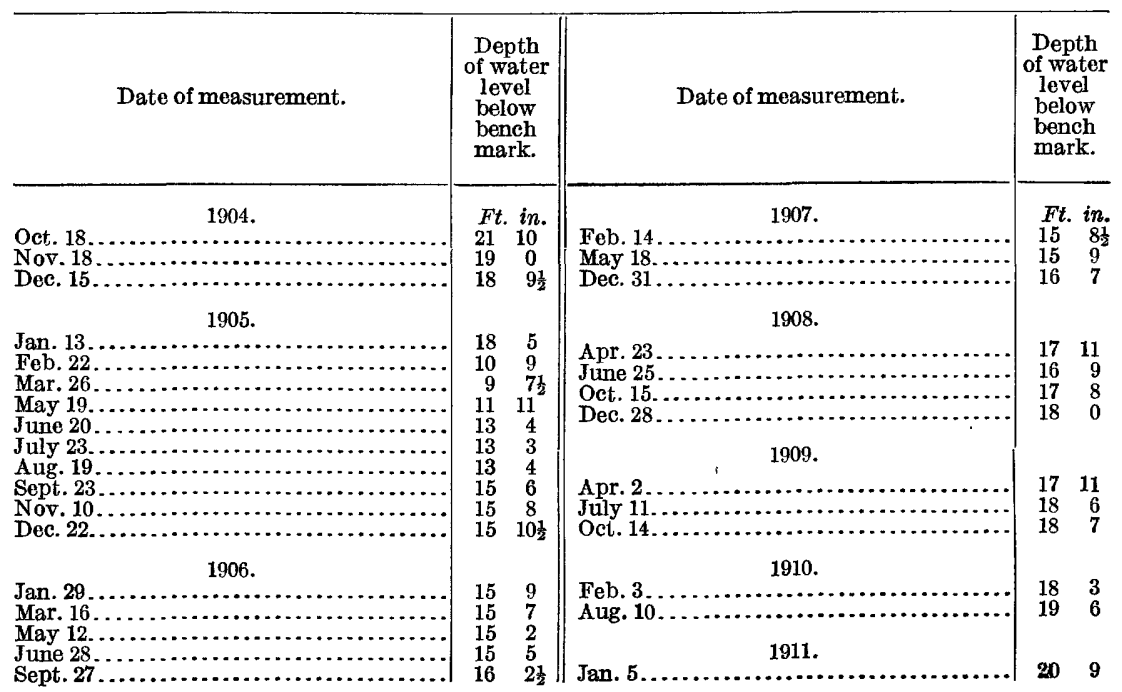


Records of water levels in the valley of southern California-Continued.

76. Dr. Reese-Continued.

\begin{tabular}{|c|c|c|c|}
\hline Date of measurement. & $\begin{array}{l}\text { Depth } \\
\text { of water } \\
\text { level } \\
\text { below } \\
\text { beneh } \\
\text { mark. }\end{array}$ & Date of measurement. & $\begin{array}{l}\text { Depth } \\
\text { of water } \\
\text { level } \\
\text { below } \\
\text { bench } \\
\text { mark. }\end{array}$ \\
\hline 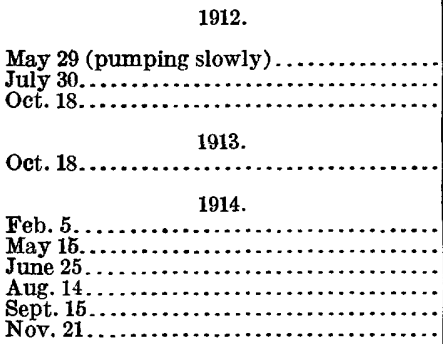 & $\begin{array}{lr}\text { Ft. } & \text { in. } \\
27 & 8 \\
25 & 1 \\
26 & 4 \\
& \\
30 & 4 \\
& \\
31 & 2 \\
31 & 5 \\
31 & 10 \\
32 & 2 \\
32 & 6 \\
33 & 1\end{array}$ & 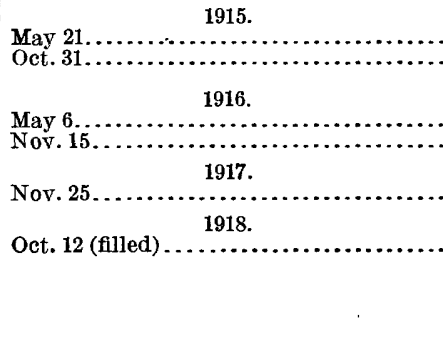 & $\begin{array}{cc}\text { Ft. } & \text { in. } \\
31 & 10 \\
32 & 2 \\
& \\
10 & 8 \\
14 & 8 \\
& \\
20 & 5 \\
& \end{array}$ \\
\hline
\end{tabular}

77. William Newport, $4 \frac{1}{2}$ miles south of Perris, Elsinore quadrangle.

[Bench mark: Top of casing, 1.0 foot above surface. Well No. 51, Water-Supply Paper 429, p. 60.]

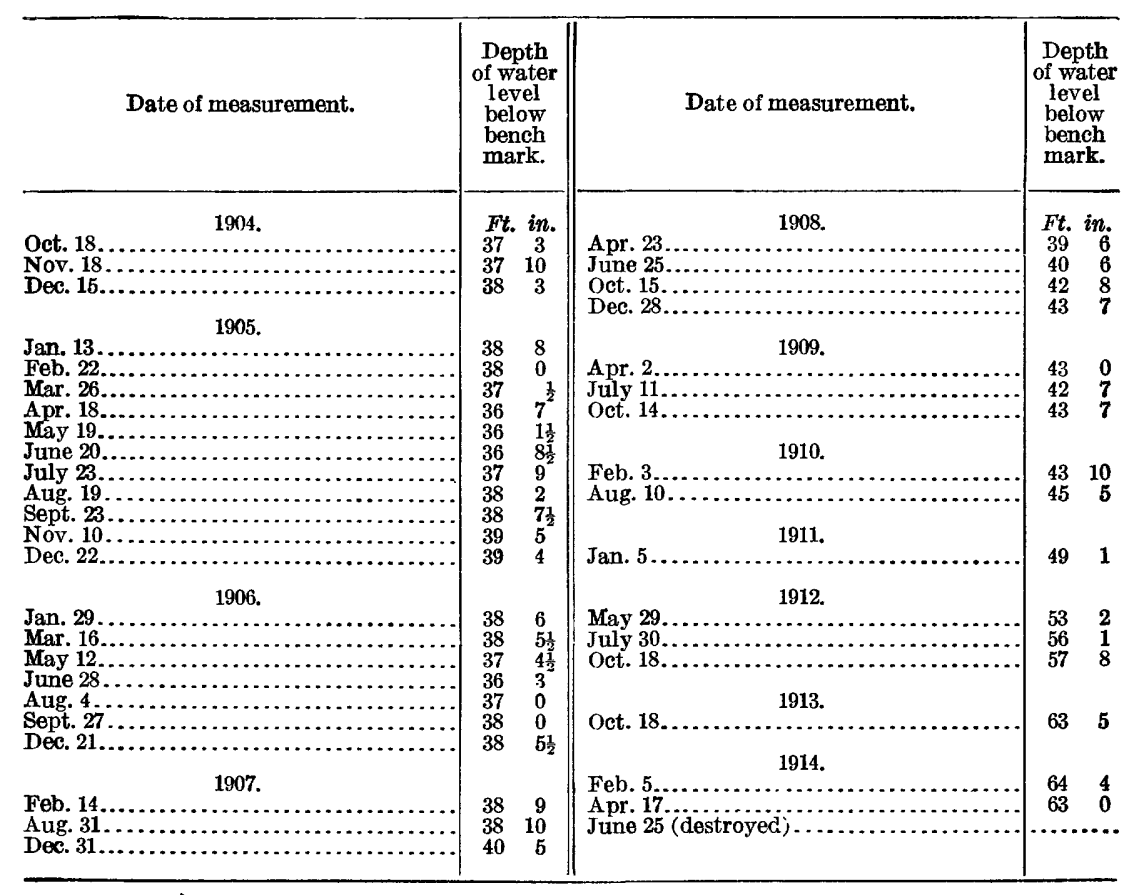


Records of water levels in the valley of southern California-Continued.

78. William Newport, Menifee Valley, Elsinore quadrangle.

[Bench mark: Top of casing, 6 inches above surface. Well No. 53, Water-Supply Paper 429, p. 66.]

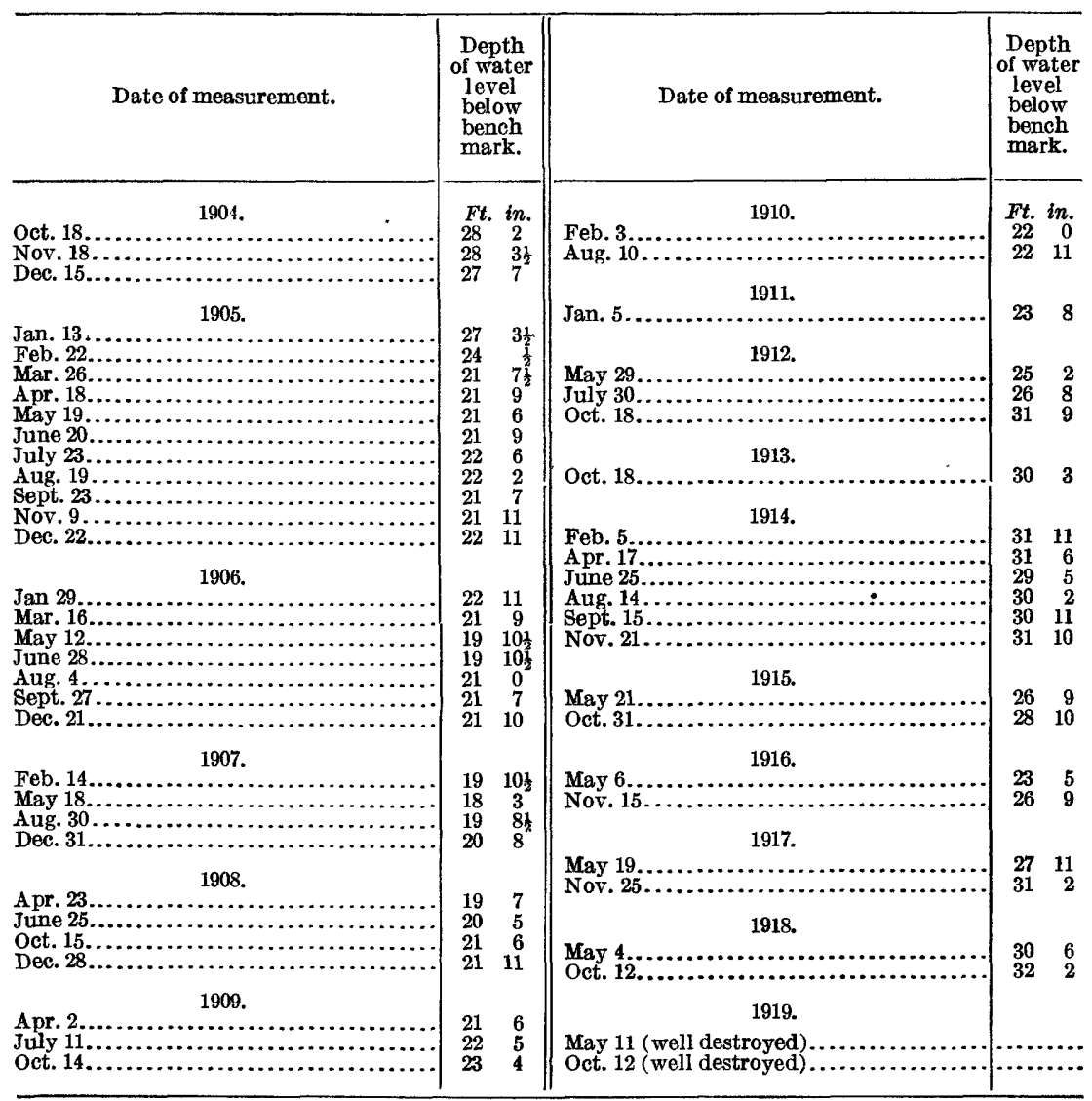

78a. Menifee School, Menifee Valley, Elsinore quadrangle.

[Companion well for No. 78, situated about 300 feet south of No. 78. Bench mark: Top of casing, level with surface.]

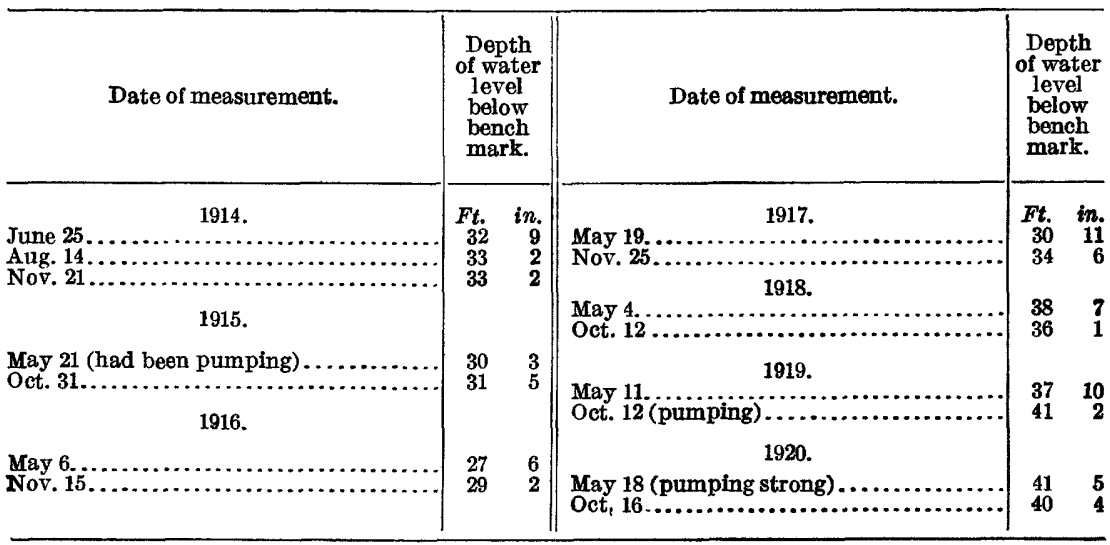


Records of water levels in the valley of southern California-Continued.

79. Mr. Ainley (formerly owned by H. H. Lindenberger), 4 miles southwest of Winchester, Elsinore quadrangle.

[Bench mark: Top of casing, 2.0 feet above surface. Well No. 56, Water-Supply Paper 429, p. 67.]

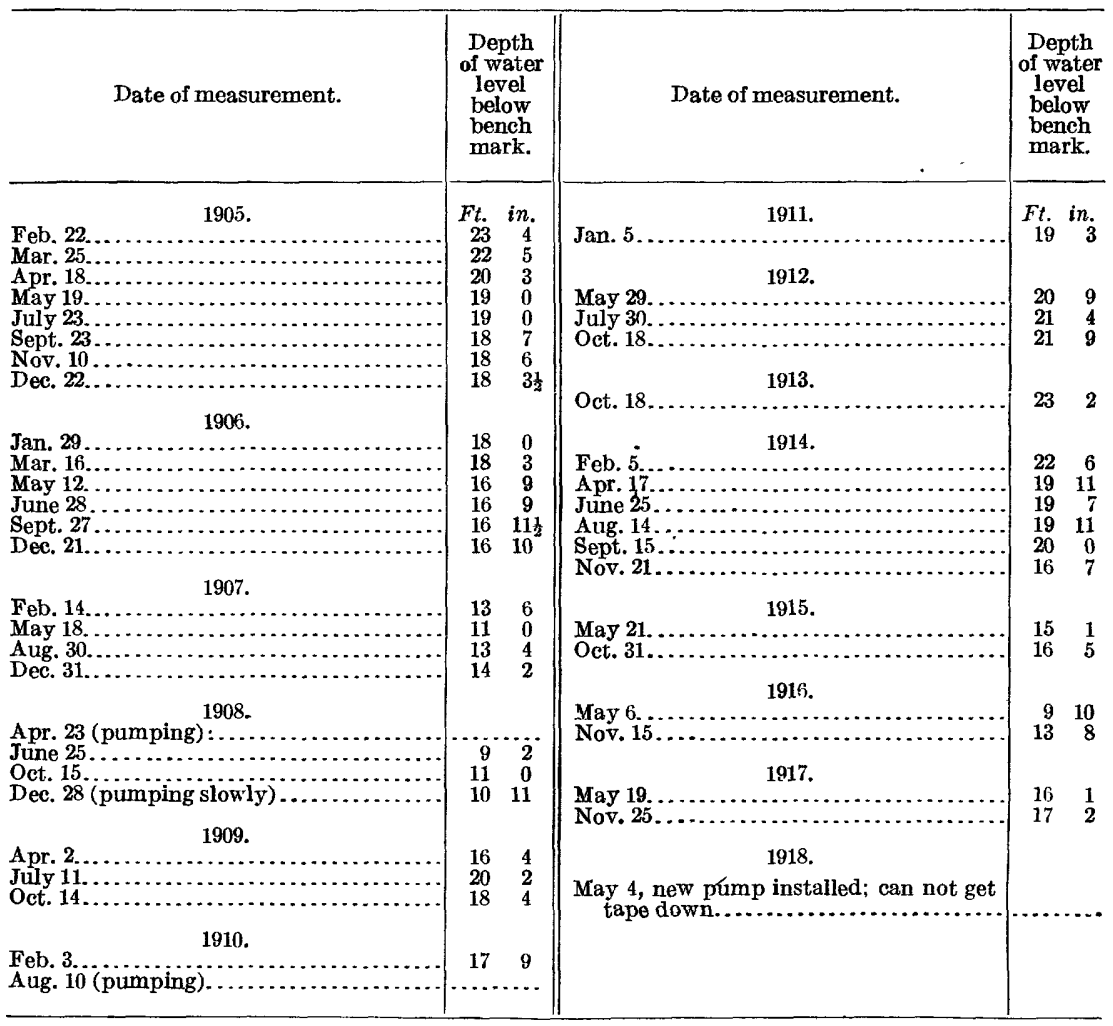

79a. W. M. Eason, 4 miles southwest of Winchester, Elsinore quadrangle.

[Companion well for No. 79, situated 1 mile west of No. 79. Bench mark: Top of curb, 2 inches above surface.]

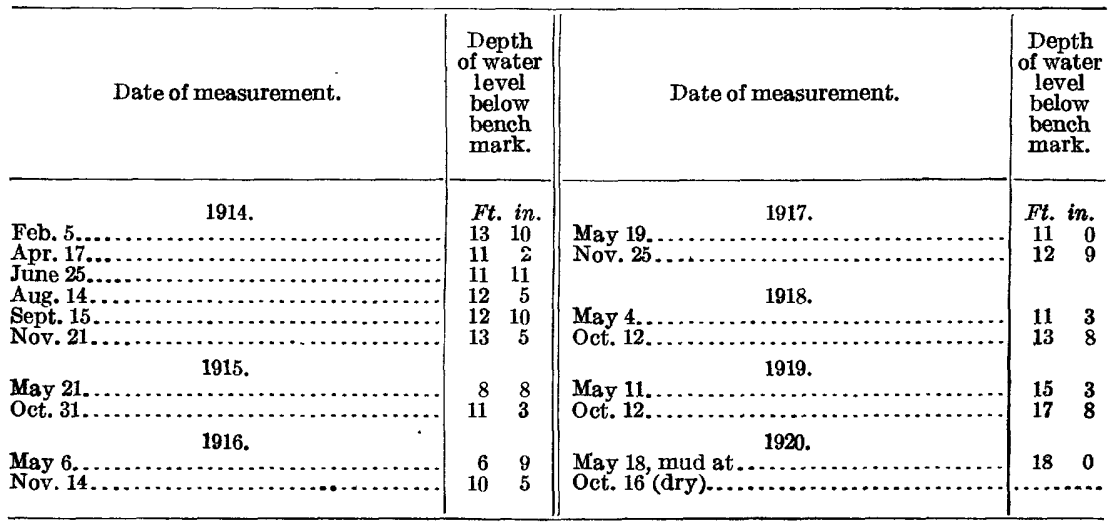


Records of water levels in the valley of southern California-Continued.

80. Miss T. Patterson, Winchester, Elsinore quadrangle.

[Bench mark: Top of cover, 6 inches above surface. Well No. 64, Water-Supply Paper 429, p. 40.]

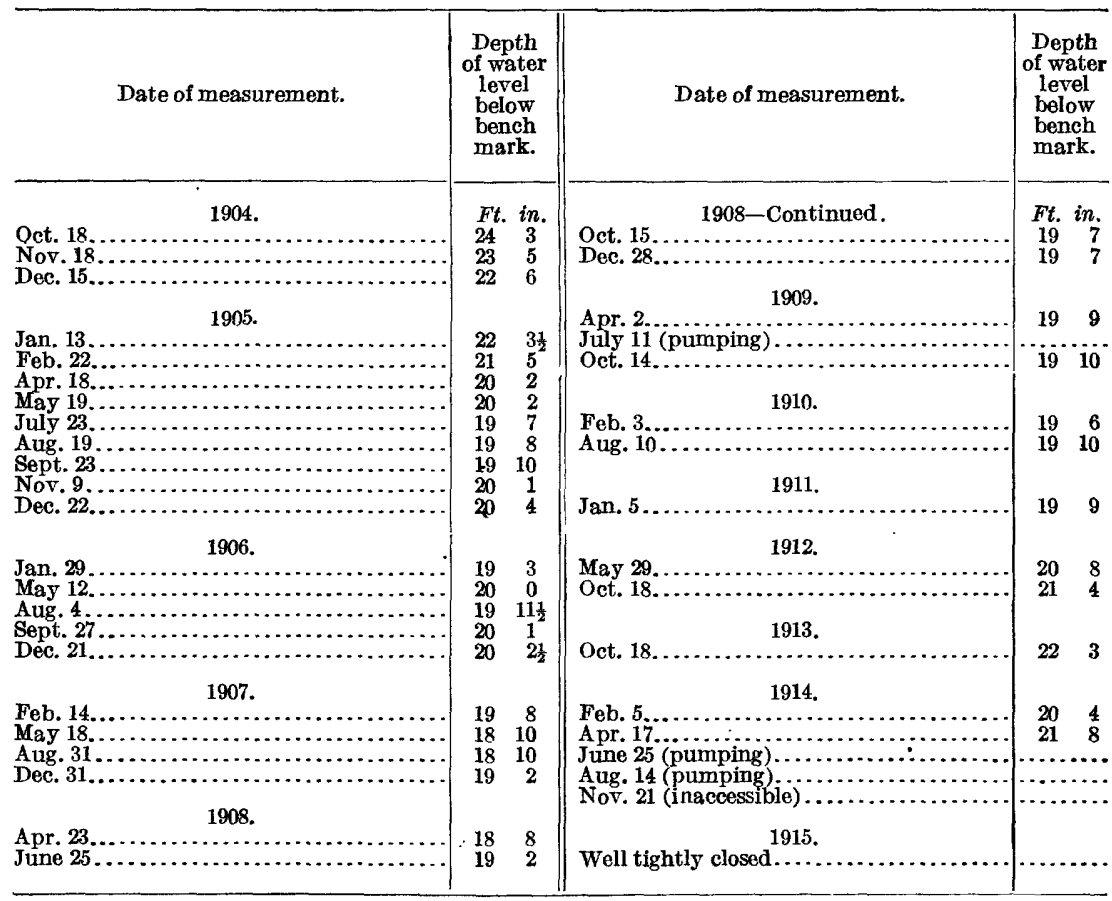

80a. Milton Thomas, Winchester, Elsinore quadrangle.

[Companion well for Nos. 80 and 80b; situated one-eighth mile south of No. 80 . Bench mark: Top of casing, 6 inches above surface.]

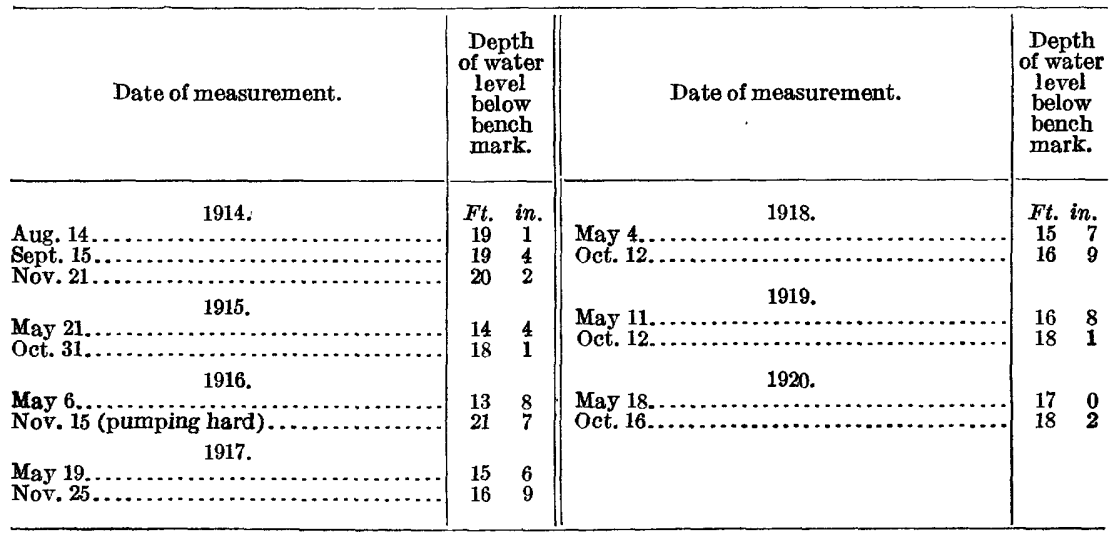


Records of water levels in the valley of southern California-Continued.

80b. W. S. Haslam, Winchester, Elsinore guadrangle.

[Has been measured in conjunction with observation wells, but record not published heretofore. Bench mark: Top of casing, 1 foot 1 inch above surface. Well No. 63, Water-supply Paper 429, p. 39.]

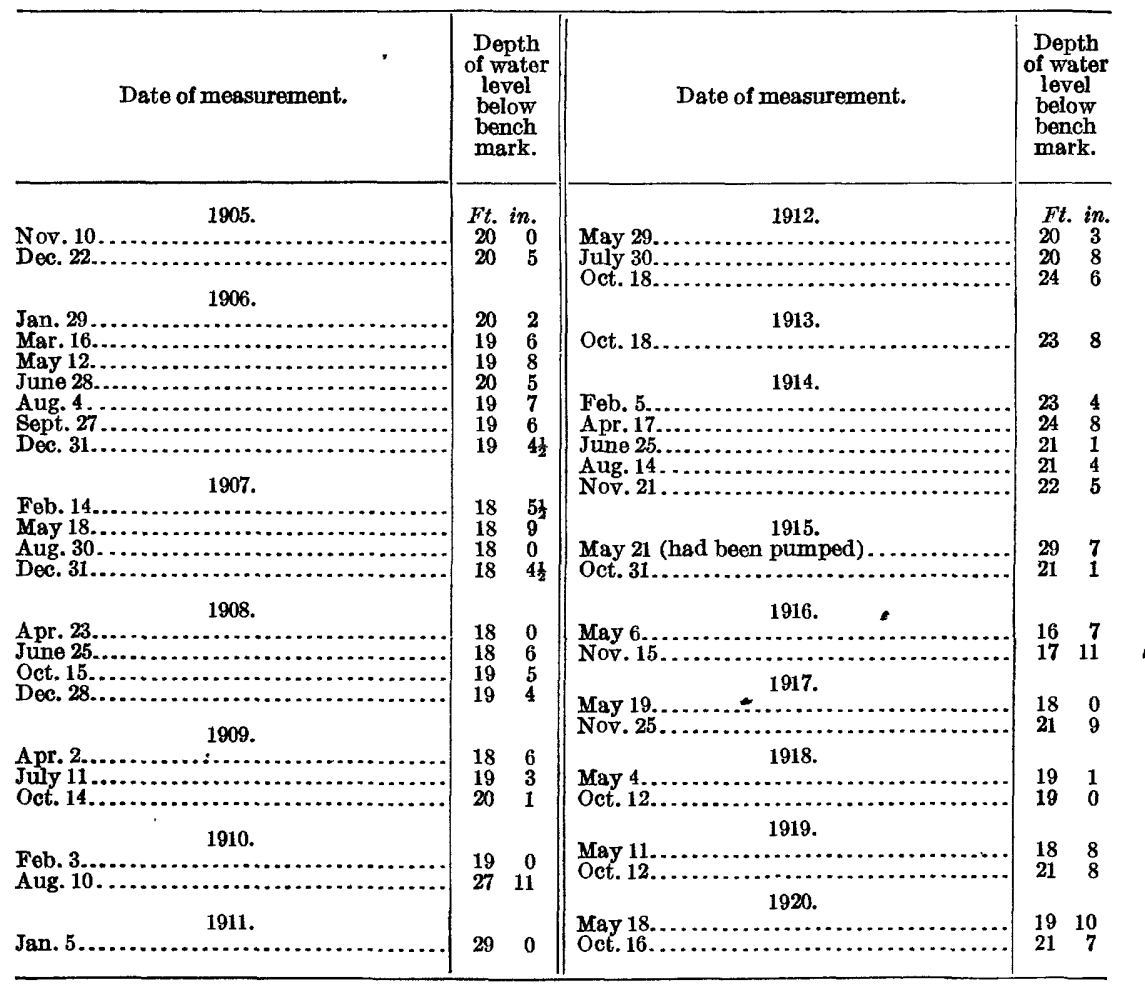


Records of water levels in the valley of southern California-Continued.

81. Mrs. Maud F. Walker, 3 miles southwest of Hemet, Elsinore quadrangle.

[Bench mark: Top of casing, 6 inches above surface. Well No. 73, Water-Supply Paper 429, p. 33.]

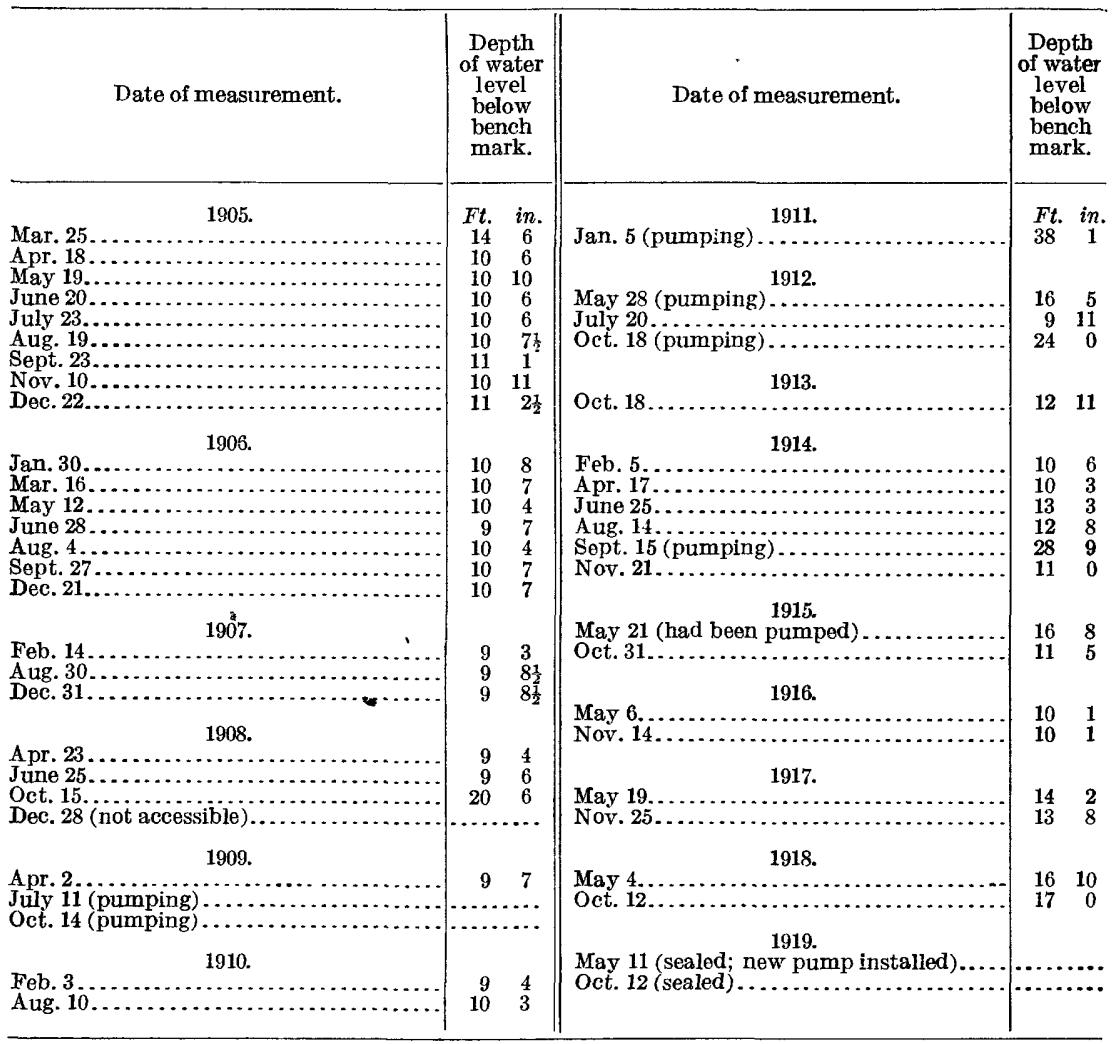

81a. L. Wilhelm, 3 miles southwest of Hemet, Elsinore quadrangle.

[Companion well for No. 81; situated one-half mile northwest of No. 81, at abandoned ranch house. Bench mark: Top of casing, 2.0 feet above surface.]

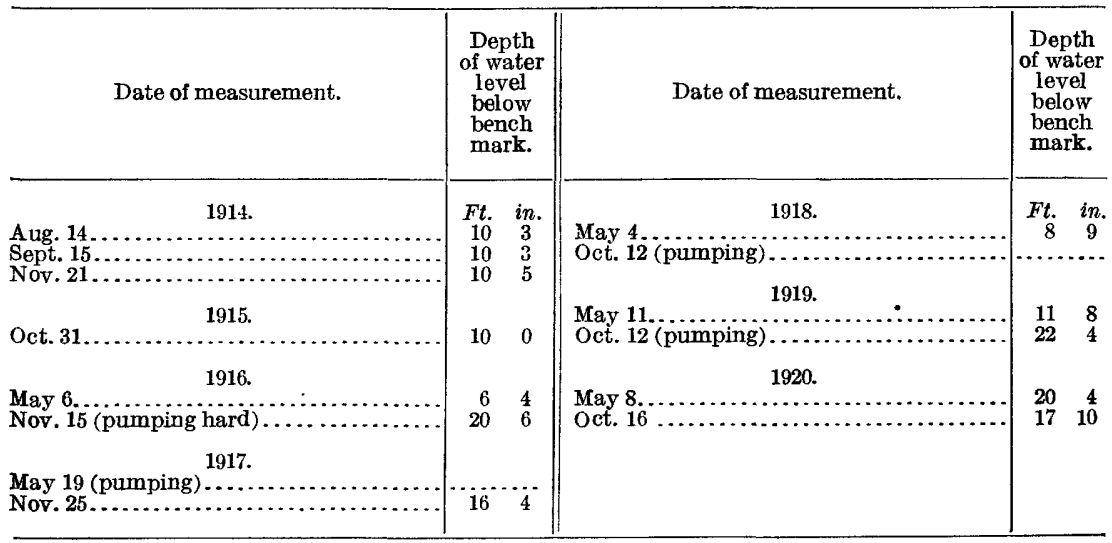


Records of water levels in the valley of southern California-Continued.

82. J. E. Garrigan, 1 mile west of Hemet, San Jacinto quadrangle.

[Bench mark: Top of casing, 11 inches above surface. Well No. 114, Water-Supply Paper 429, p. 34.]

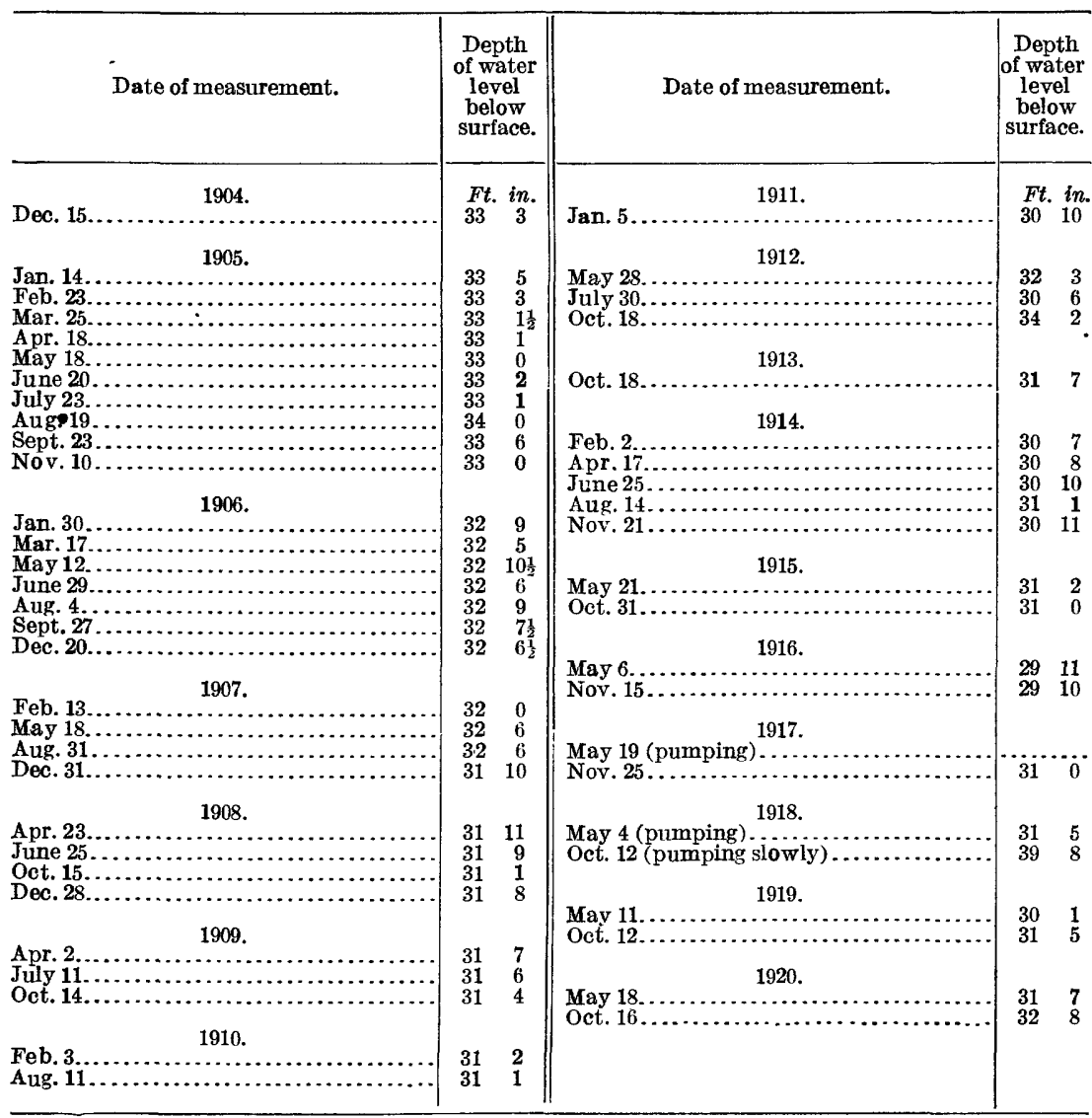

82a. Mr. Smyres, seven-eighths mile west of Hemet, San Jacinto quadrangle.

[Companion well for No. 82 , situated about 600 feet east of No. 82 . Bench mark: Top of casing, 2.0 feet above surface.!

\begin{tabular}{|c|c|c|c|}
\hline Date of measurement. & $\begin{array}{l}\text { Depth } \\
\text { of water } \\
\text { level } \\
\text { below } \\
\text { bench } \\
\text { mark. }\end{array}$ & Date of measurement. & $\begin{array}{c}\text { Depth } \\
\text { of water } \\
\text { level } \\
\text { below } \\
\text { bench } \\
\text { mark. }\end{array}$ \\
\hline 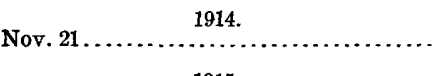 & $\begin{array}{lc}F t . & \text { in. } \\
38 & 1\end{array}$ & $\begin{array}{l}1918 . \\
\text { May } 4 \text { (had been pumping) } \ldots \ldots \ldots \ldots \ldots \\
\text { Oct. } 12 \ldots \ldots \ldots \ldots \ldots \ldots \ldots \ldots \ldots \ldots \ldots \ldots\end{array}$ & $\begin{array}{lc}\text { Ft. } & \text { in } \\
39 & 5 \\
43 & 4\end{array}$ \\
\hline 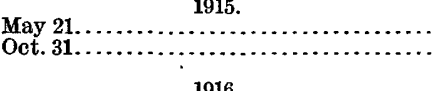 & $\begin{array}{ll}40 & 0 \\
38 & 5\end{array}$ & 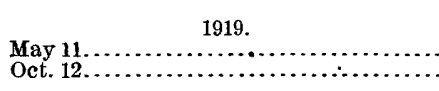 & $\begin{array}{rr}38 & 6 \\
39 & 11\end{array}$ \\
\hline 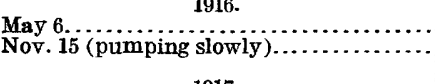 & $\begin{array}{lr}37 & 5 \\
38 & 10\end{array}$ & 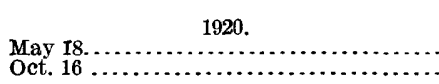 & $\begin{array}{rr}39 & 10 \\
41 & 2\end{array}$ \\
\hline 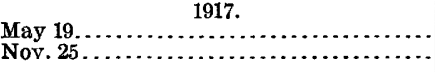 & $\begin{array}{rr}36 & 11 \\
37 & 5\end{array}$ & & \\
\hline
\end{tabular}


Records of water levels in the valley of southern California-Continued.

83. H. R. Kumler (formerly owned by Mrs. Ruby Hewitt), one-half mile east of Bowers, San Jaeinto quadrangle.

[Bench mark not known. Well No. 126, Water-Supply Paper 429, p. 29.]

\begin{tabular}{|c|c|c|c|}
\hline Date of measurement. & $\begin{array}{l}\text { Depth } \\
\text { of water } \\
\text { level } \\
\text { below } \\
\text { bench } \\
\text { mark. }\end{array}$ & Date of measurement. & $\begin{array}{l}\text { Depth } \\
\text { of water } \\
\text { level } \\
\text { below } \\
\text { bench } \\
\text { mark. }\end{array}$ \\
\hline 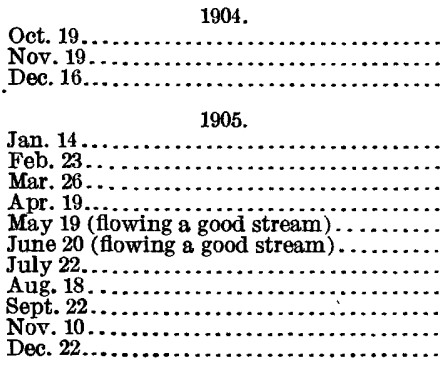 & \begin{tabular}{|rr} 
Fl. & in. \\
11 & 5 \\
11 & 9 \\
12 & 2 \\
& \\
& \\
12 & 4 \\
10 & 1 \\
5 & 5 \\
2 & 1 \\
$\cdots$ & \\
\hdashline & 7 \\
1 & 8 \\
3 & 2 \\
4 & $7 \frac{1}{3}$ \\
5 & $7 \frac{1}{2}$
\end{tabular} & 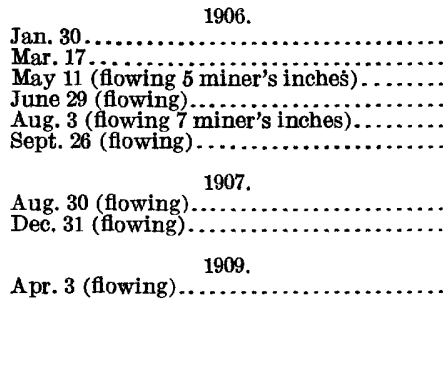 & 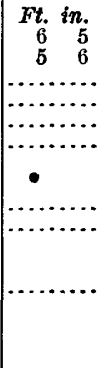 \\
\hline
\end{tabular}

83a. J. A. Barger (formerly owned by W. D. Baisley), 1 mile northeast of Hemet, San Jacinto quadrangle.

[Has been measured in conjunction with observation wells, but record not published heretofore. Bench mark: Top of casing, 8inches above surface. Well No. 118, Water-Supply Paper 429, p. 35.]

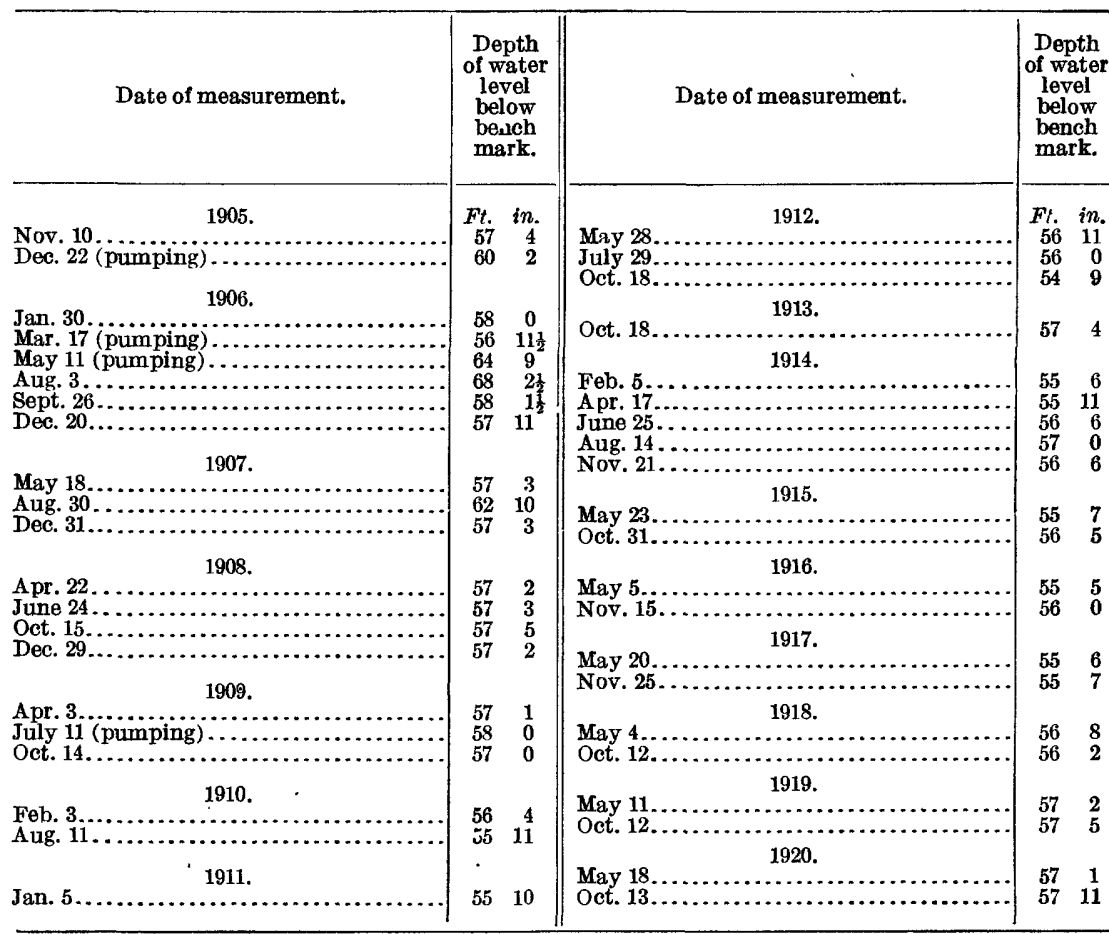


Records of water levels in the valley of southern California-Continued.

84. C. A. Holmes (formerly owned by J. Carmichael), Bowers, San Jacinto quadrangle.

[Bench mark: Top of casing, originally 2 feet 2 inches above surface. Between Oct. 12, 1919, and May 18, 1920, a pumping motor was installed and 2 feet of casing removed. Two feet was added to the measurements made May 18 and Oct. 13, 1920, to make them comparable with previous measurements. Well No. 125, Water-Supply Paper 429, p. 28.]

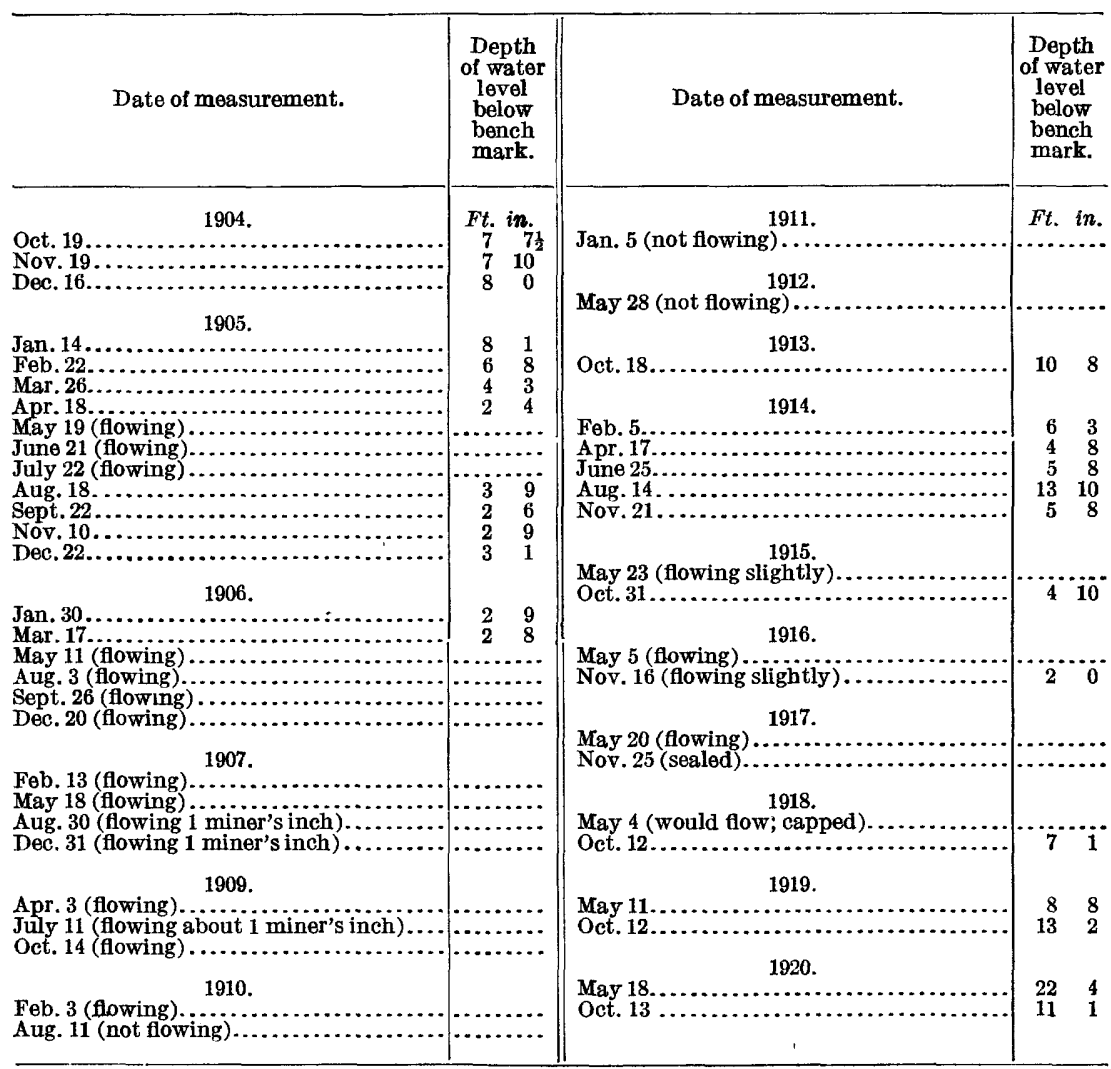

84a. Josê G. Estudillo, Bowers, San Jacinto quadrangle.

[Companion well for No. 84, situated about 300 feet east of No. 84. Bench mark: Pump base, 1 foot 10 inches above surface.]

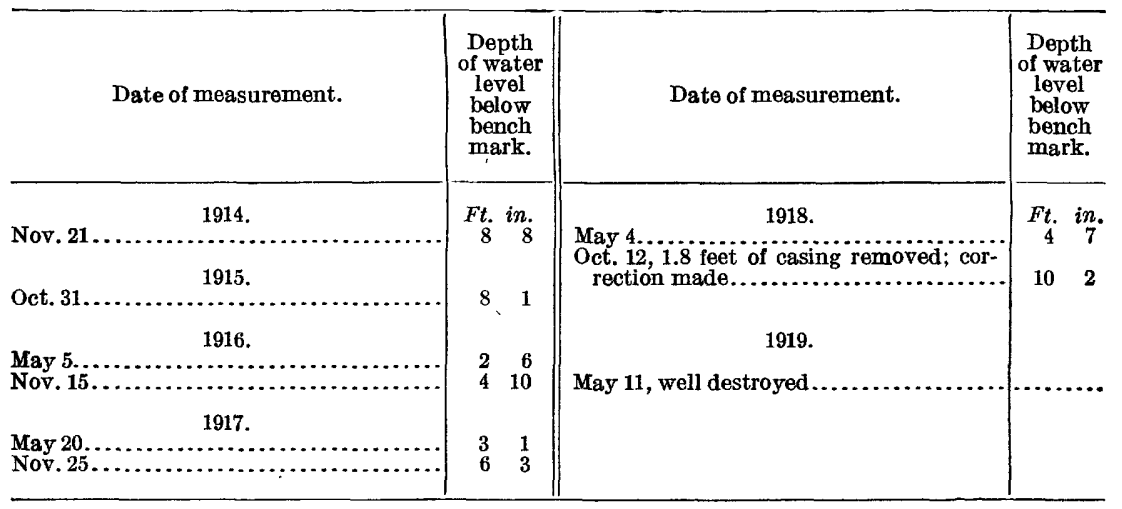


Records of water levels in the valley of southern California-Continued.

85. Albert McDonald (formerly owned by K. D. Harger), Lakeview, Elsinore quadrangle.

[Bench mark: Top of casing; 6 inches above surface. Well No. 18, Water-Supply Paper 429, p. 44.]

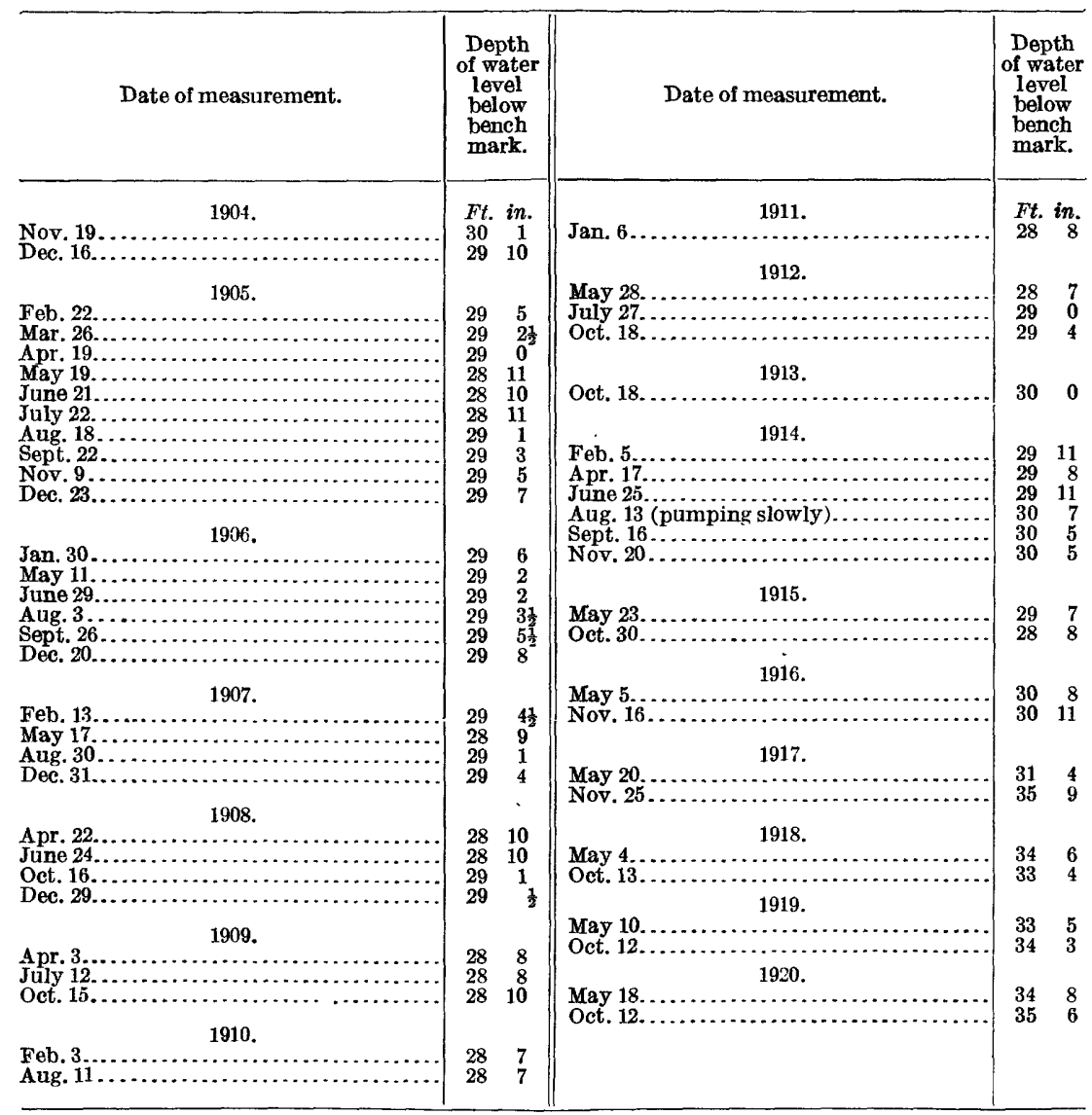


Records of water levels in the valley of southern California-Continued.

85a. County well, Lakeview, Elsinore quadrangle.

[Has been measured in conjunction with observation wells, but record not published heretofore. Bench mark: Top of casing, 2 foet above surface. Well No. 19, Water-Supply Paper 429, p. 45. Companion well for No. 85.]

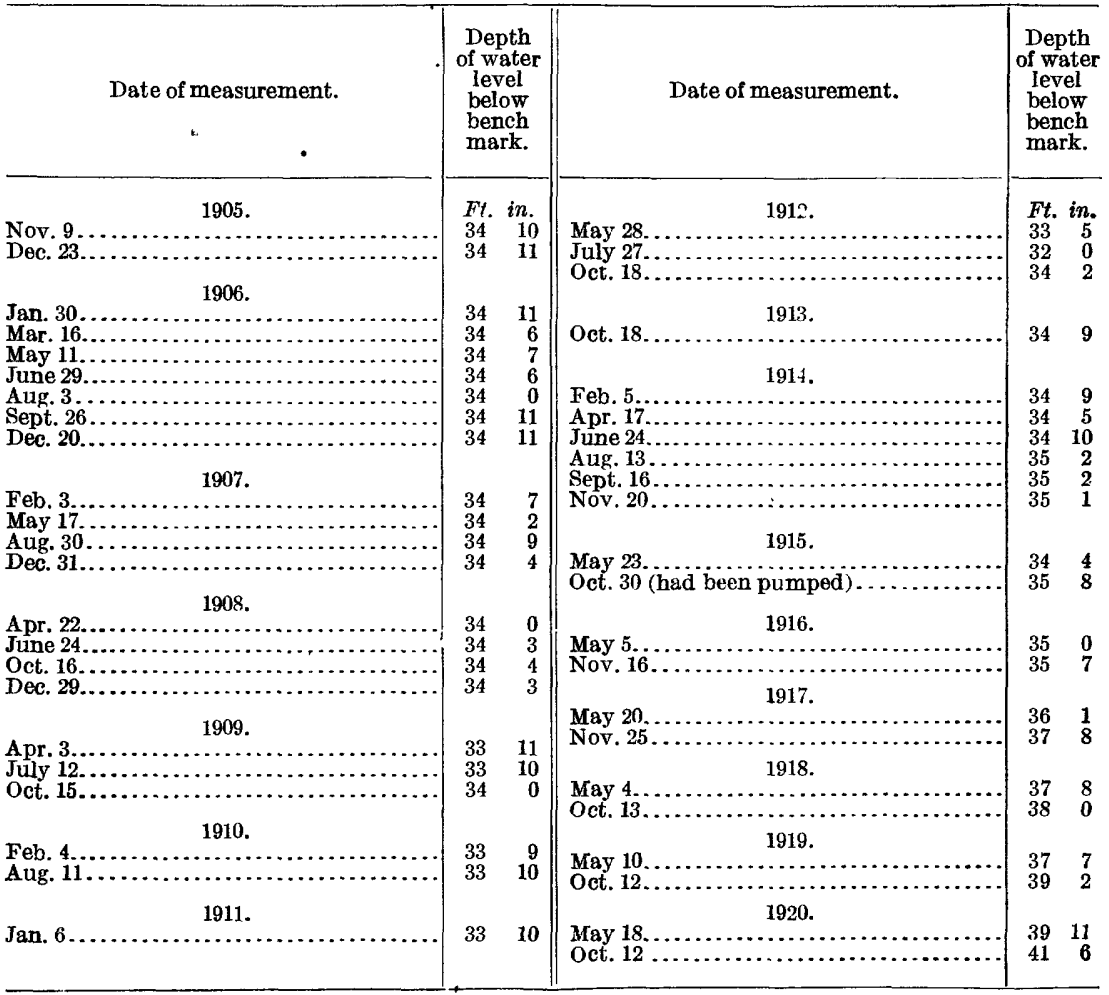


Records of water levels in the valley of southern California-Continued.

86. Mr. Woodbridge (formeriy owned by A. W. Bemis), 2 miles west of San Bernardino, San Bernardino quadrangle.

[Well, 48 feet deep, 8-inch casing; sunk in 1890; method of lift, wind; use, domestic. Bench mark: Top of casing, 1 foot 7 inches above surface. Altitude of bench mark, $1,130.8$ feet above sea level. Companion well for No. 441, Water-Supply Paper 142, p. 116, which was destroyed.]

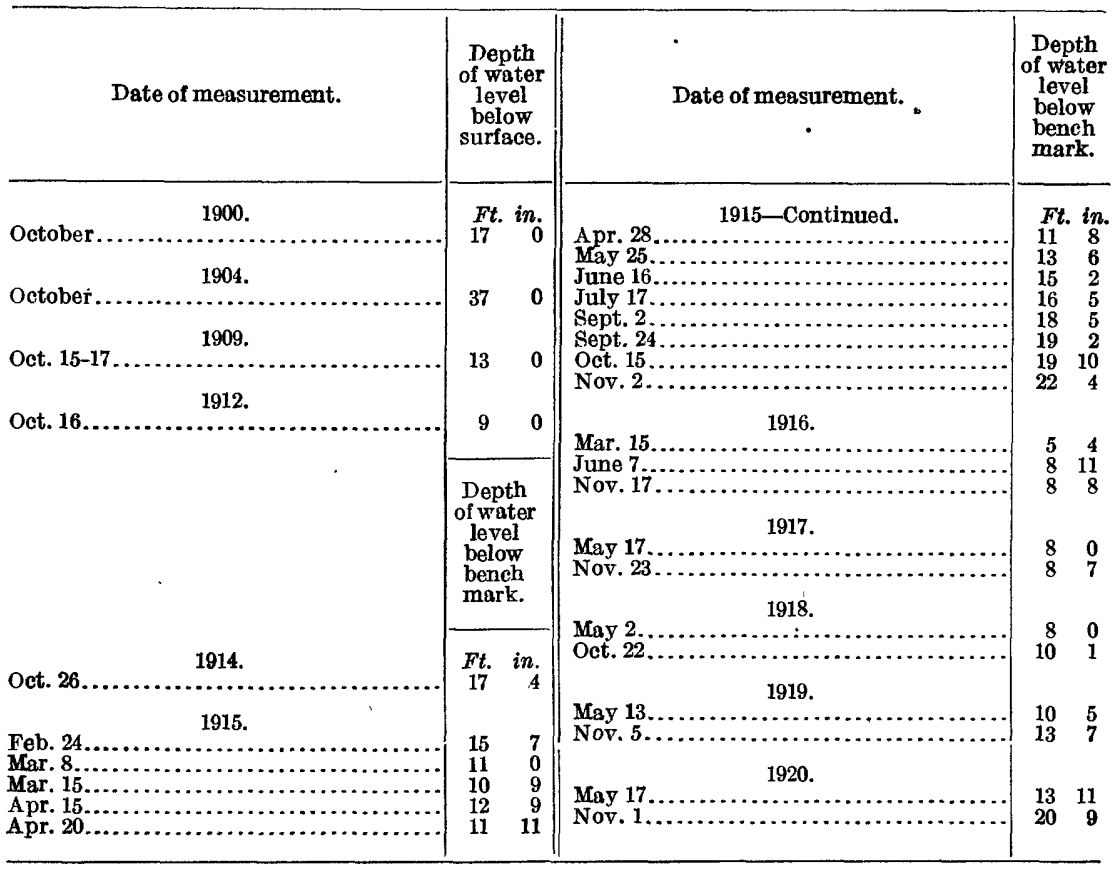

87. G. Renwick, 1s miles south of San Bernardino, San Bernardino quadrangle.

[Well, 186 feet deep, 6-inch casing; method of lift, wind; use, domestic. Bench mark: Ton of casing, at surface. Altitude of bench mark, 1,100.85 feet above sea level. Well No. 277, Water-Supply Paper 142, p. 109.]

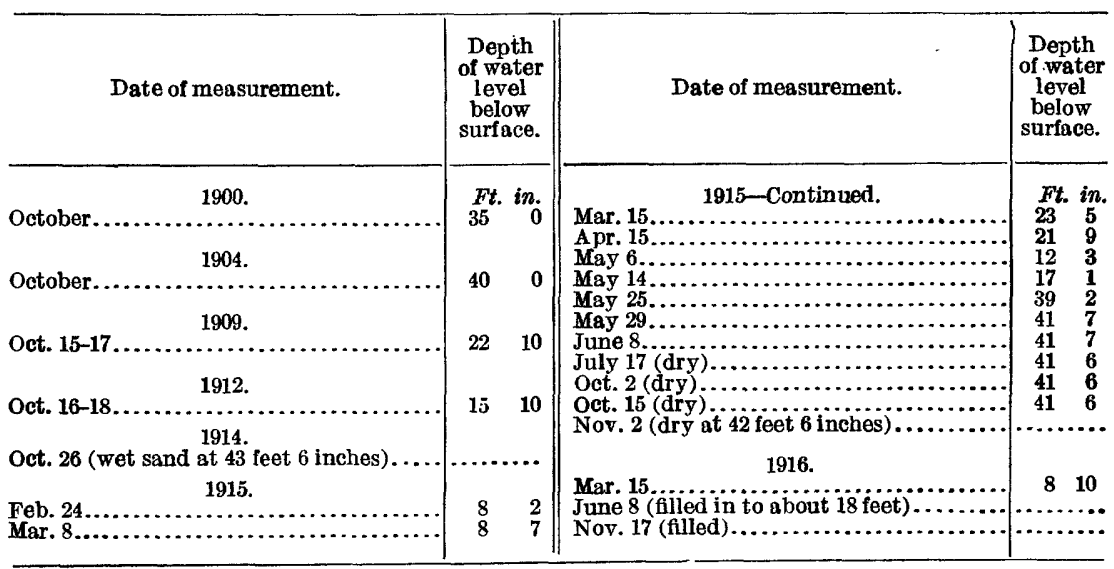


Records of water levels in the valley of southern California-Continued.

88. S. A. Jackson (formerly owned by M. D. Reynolds), $1 \frac{1}{4}$ miles northwest of San Bernardino, San Bernardino quadrange.

[Well, 40 teet deep, 7-inch casing; sunk in 1898; method of lift, wind use. domestic. Bench mark: Top of casing, 1 foot, 7 inches above su'face. Well No. 450, Water-Supply Paper 142, p. 116.]

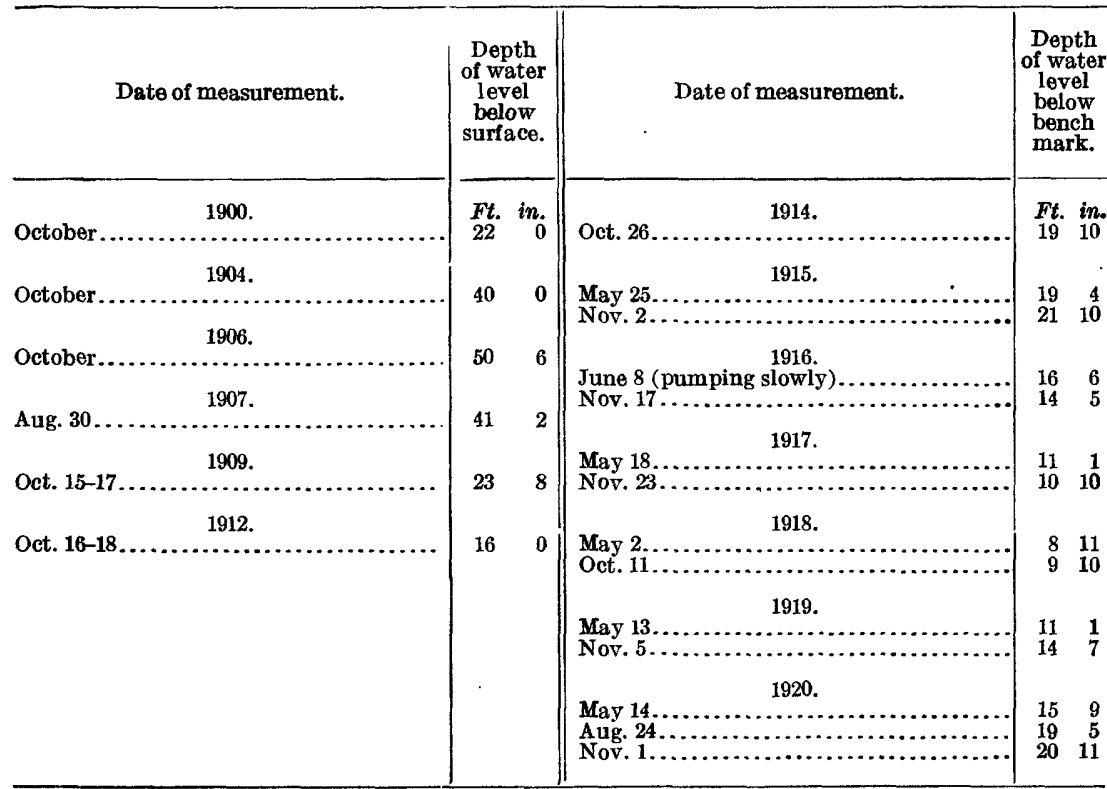

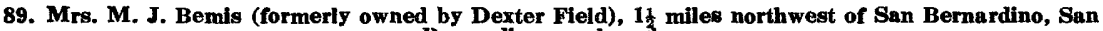
Bernardino quadrangle.

[Well, 45 fcet deep, 6-inch casing; sunk in 1870; method of lift, wind; use, domestic. Bench mark: Top of casing, 1 foot above surface. Altitude of bench mark, $1,155.47$ above sea level. Well No. 375, WaterSupply Paper 142, p. 113.]

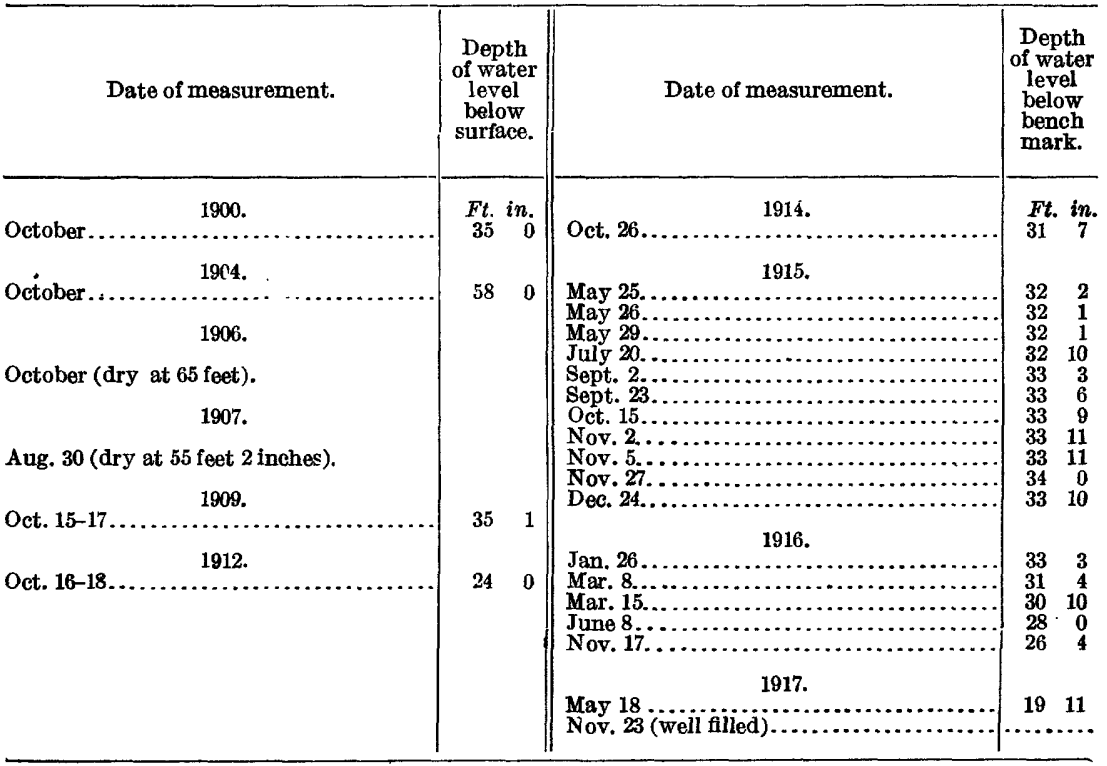


Records of water levels in the valley of southern California-Continued.

90. F. Alvarado, $2 \frac{1}{4}$ miles northwest of San Bernardino, San Bernardino quadrangle.

[Well, 93 feet deep, 7-inch casing; sunk in 1900. Bench mark: Top of casing, 1 foot 2 inches above surface. Altitude of bench mark, 1,186.59 feet above sea level. Well No. 364, Water-Supply Paper 142, p. 112.]

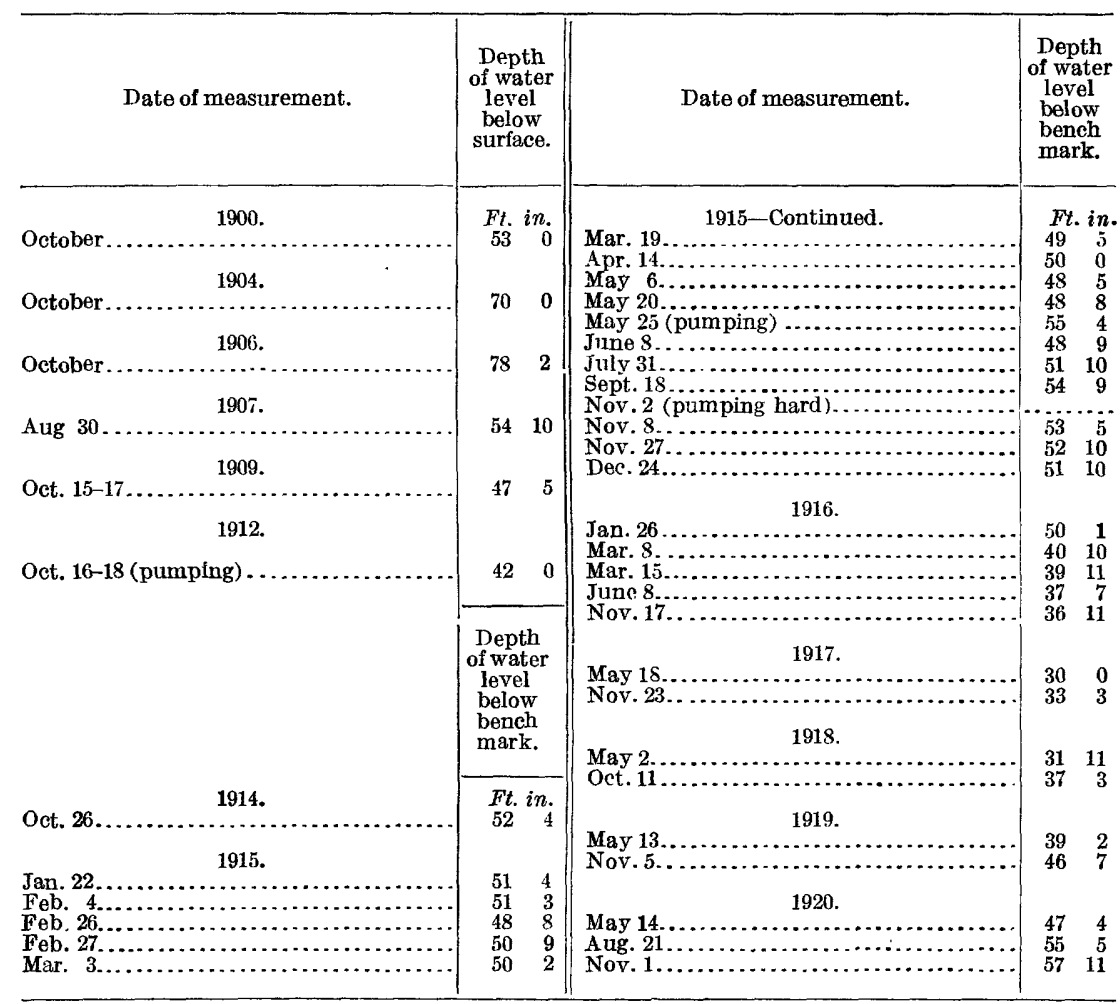

91. S. W. Harmon (formerly owned by Mr. Orric), 2 miles northwest of San Bernardino, San Bernardino quadrangle.

[Well, 83 feet deep, 7-inch pipe; sunk in 1882; method of lift, wind; use, domestic and irrigation. Bench mark: Top of blocks, 3 feet 1 inch above surface. Well No. 393. Water-Supply Paper 142, p. 113.]

\begin{tabular}{|c|c|c|c|}
\hline Date of measurement. & $\begin{array}{l}\text { Depth } \\
\text { of water } \\
\text { level } \\
\text { below } \\
\text { surface. }\end{array}$ & Date of measurement. & $\begin{array}{l}\text { Depth } \\
\text { of water } \\
\text { level } \\
\text { below } \\
\text { bench } \\
\text { mark. }\end{array}$ \\
\hline \multirow[t]{2}{*}{ Oet. $16-18 \ldots \ldots \ldots$} & $\underset{38}{\text { Ft. }}{ }_{i}$ & \multirow{4}{*}{ 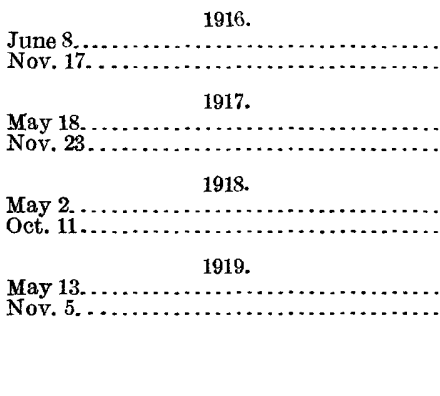 } & \multirow[t]{4}{*}{$\begin{array}{rr}\text { Ft. } & \text { in. } \\
42 & 8 \\
39 & 6\end{array}$} \\
\hline & $\begin{array}{l}\text { Depth } \\
\text { of water } \\
\text { level } \\
\text { below } \\
\text { bench } \\
\text { mark. }\end{array}$ & & \\
\hline Oct. $26 \ldots \ldots \ldots \ldots \ldots \ldots \ldots \ldots$ & \multirow{2}{*}{$\begin{array}{ll}48 & 0 \\
& \\
48 & 1 \\
49 & 2\end{array}$} & & \\
\hline 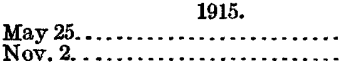 & & & \\
\hline
\end{tabular}


Records of water levels in the valley of southern California-Continued.

92. Mrs. Sarah Green (formerly owned by J. H. Lytle), 2 miles northwest of San Bernardino, San Bernardino quadrangle.

[Well, 79 feet deep, 7-inch casing; sunk in 1885; method of lift, wind; use, domestic and irrigation. Bench mark: Top of casing, at surface. Altitude of bench mark, 1,165.40 feet above sea level. Well No. 400, Water-Supply Paper 142, p. 114.]

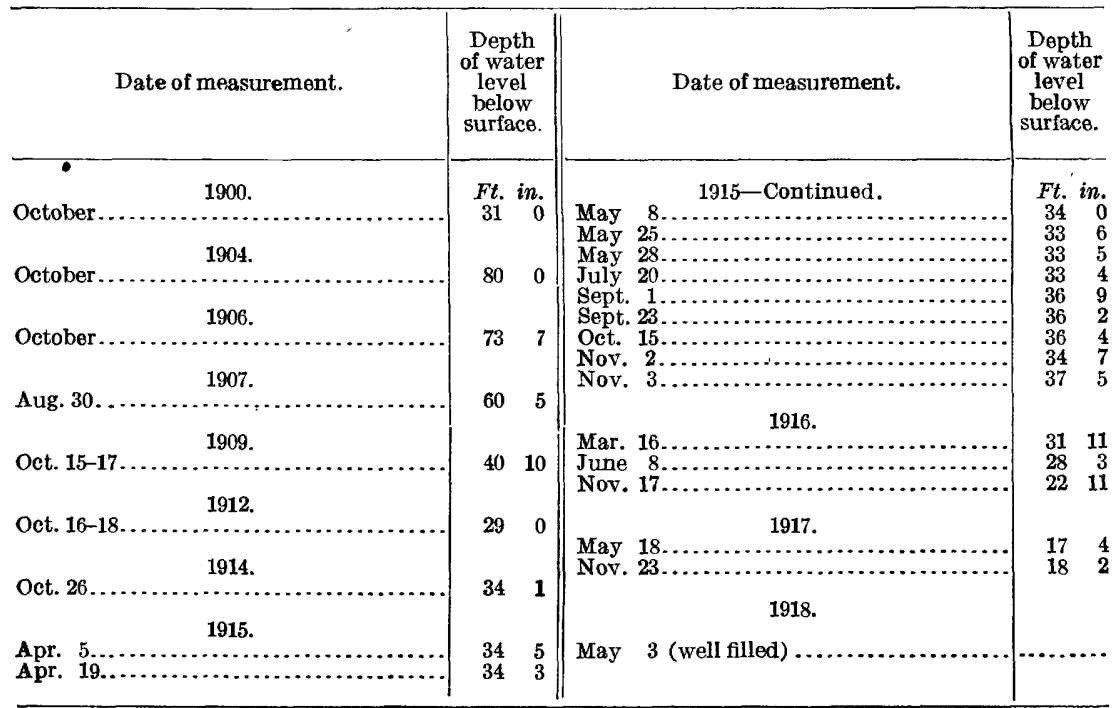

93. N. M. Swarthout, $1 \frac{3}{4}$ miles north of San Bernardino, San Bernardino quadrangle.

[Well, 75 feet deep, 7-inch casing; sunk in 18S5; method of lift, wind; use, domestic. Bench mark: Top of blocks, 1 foot above surface. Well No. 398, Water-Supply Paper 142, p. 114.]

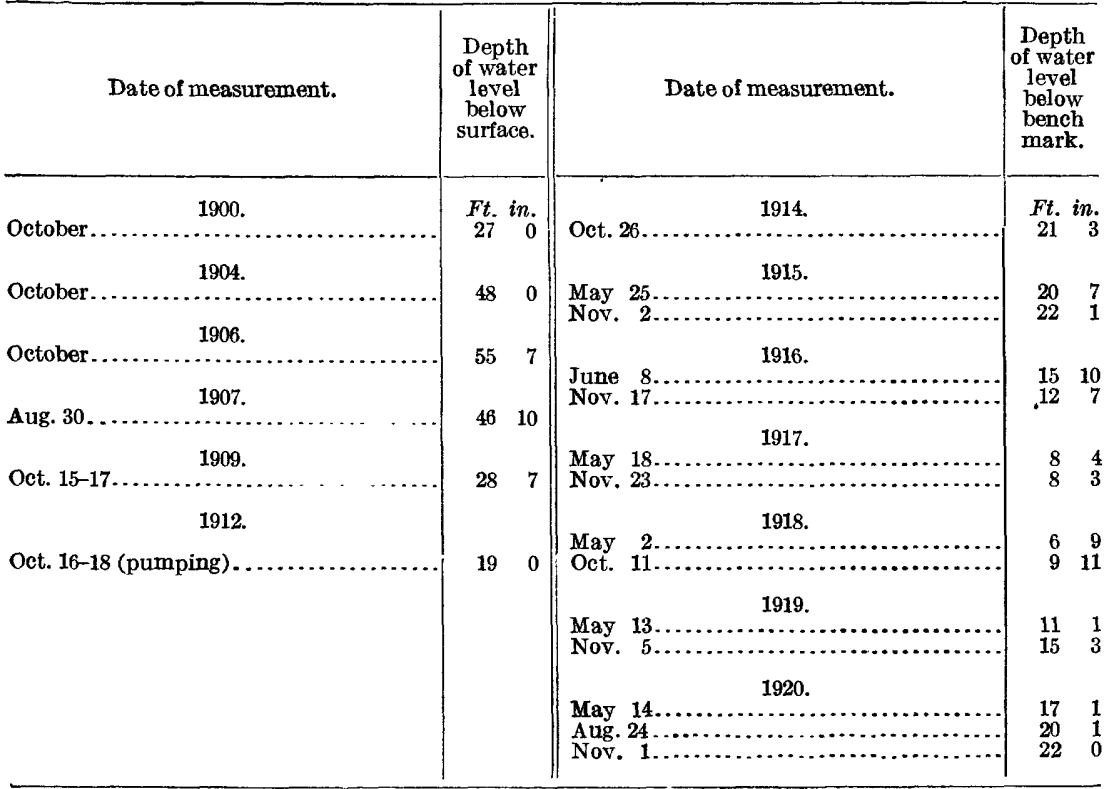


Records of water levels in the valley of southern California-Continued.

94. S. F. Kelly, 2 miles north of San Bernardino, San Bernardino quadrangle.

[Well, 115 feet deep, 7-inch casing; sunk in 1897; method of lift, wind; use, irrigation and domestic. Bench mark: Top of blocks, 2 feet 10 inches above surface. Altitude of bench mark, 1,171.03 feet above sea level. Well No. 354, Water-Supply Paper 142, p. 112.]

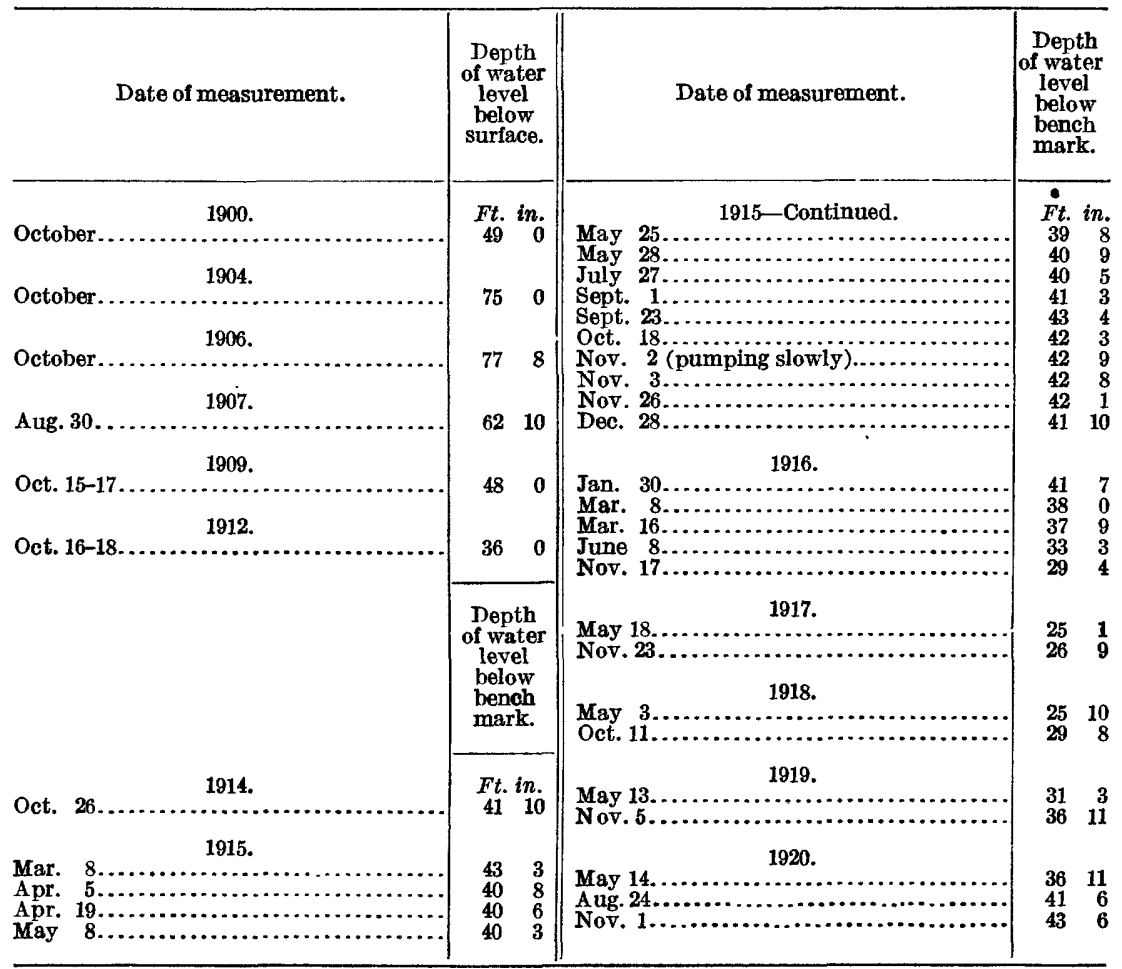


Records of water levels in the valley of southern California-Continued.

95. S. H. Johnson, 21 miles north of San Bernardino, San Bernardino quadrangle.

LWell, 84 feet deep, 7-inch casing; sunk in 1885; method of lift, wind; use, domostic. Bench mark: Top of casing, 1 foot 7 inches above surface. Altitude of bench mark, 1,182 feet above sea level. Well No. 357 , Water-Supply Paper 142, p. 112.]

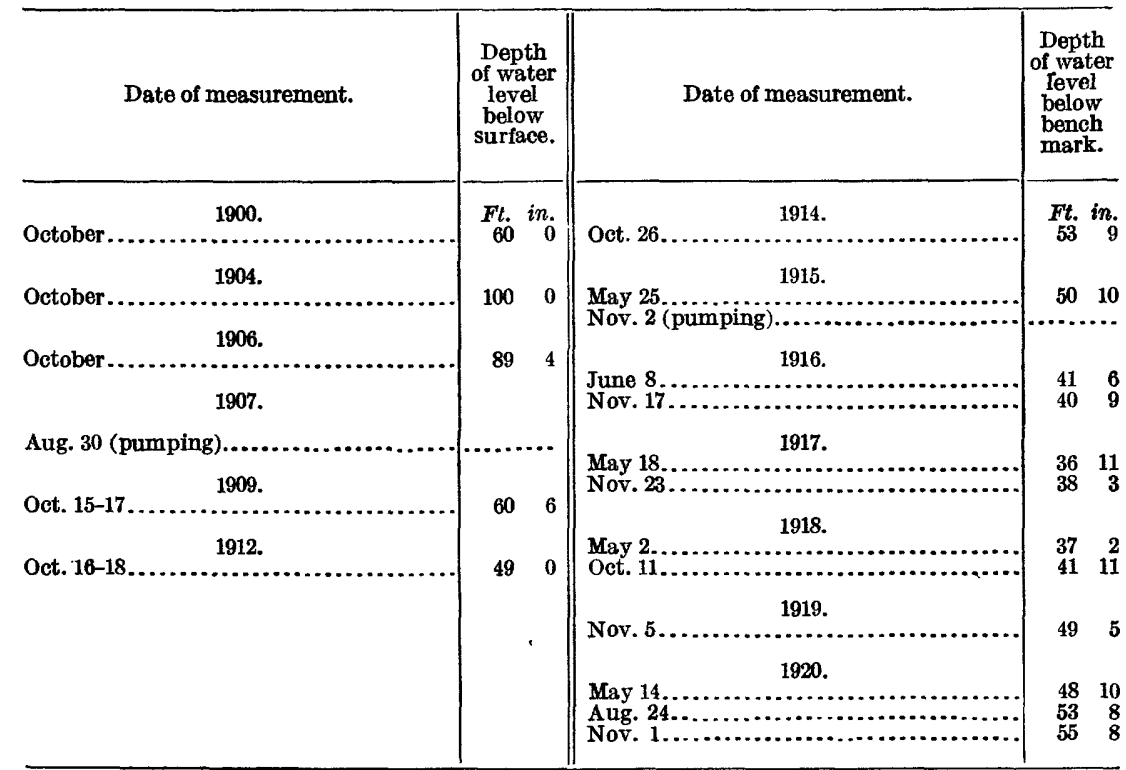

96. H. N. Stones, 2 miles northeast of San Bernardino, San Bernardino quadrangle.

[Well, 85 feet deep, 7-inch casing; sunk in 1884; method of lift, wind; use, domestic and stock. Bench mark: Top of casing, at surface. Altitude of bench mark, 1,151.84 feet above sea level. Well No. 341, Water-Supply Paper 142, p. 111.]

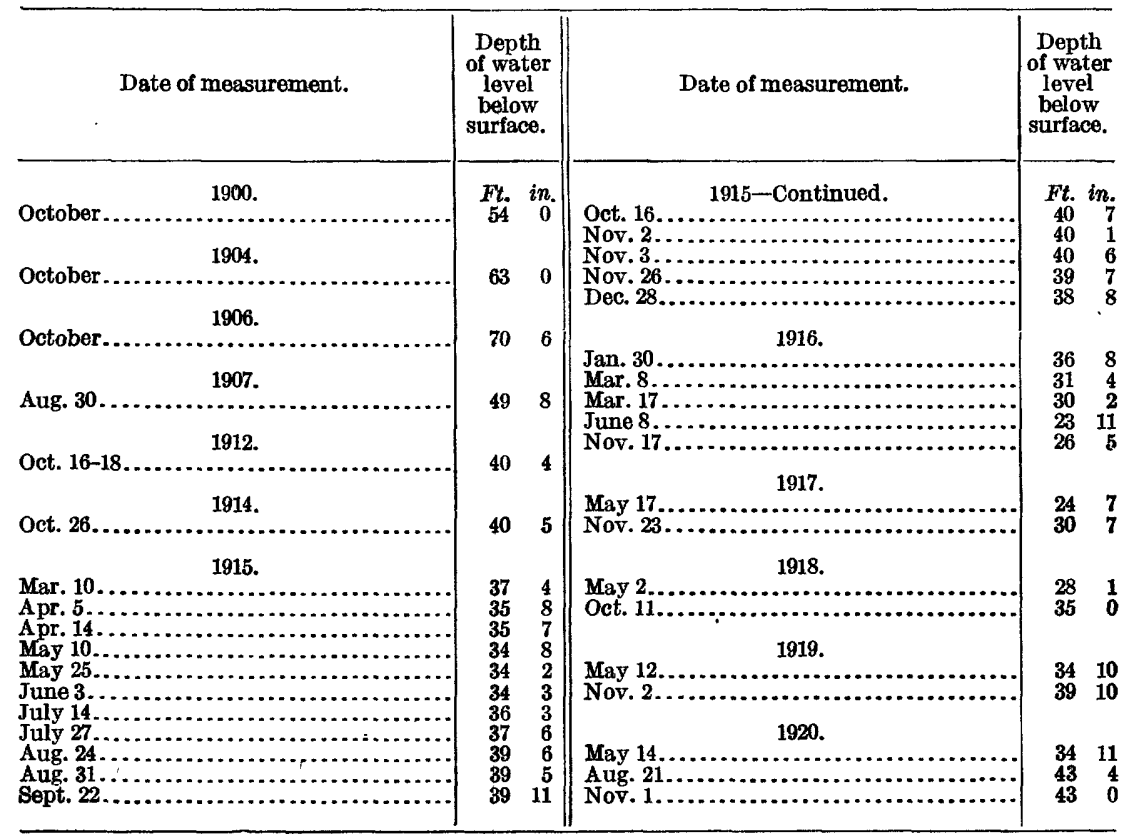


Records of water levels in the valley of southern California-Continued.

97. Albert Hart (formerly owned by James Dickson), $2 \frac{1}{4}$ miles northeast of San Bernardino, San Bernardino quadrangle.

[Well, 44 feet deep, 10-inch casing; sunk in 1888; method of lift, wind; use, domestic. Bench mark: Top of casing, 1 foot 5 inches above surface. Well No. 319, Water-Supply Paper 142, p. 111.]

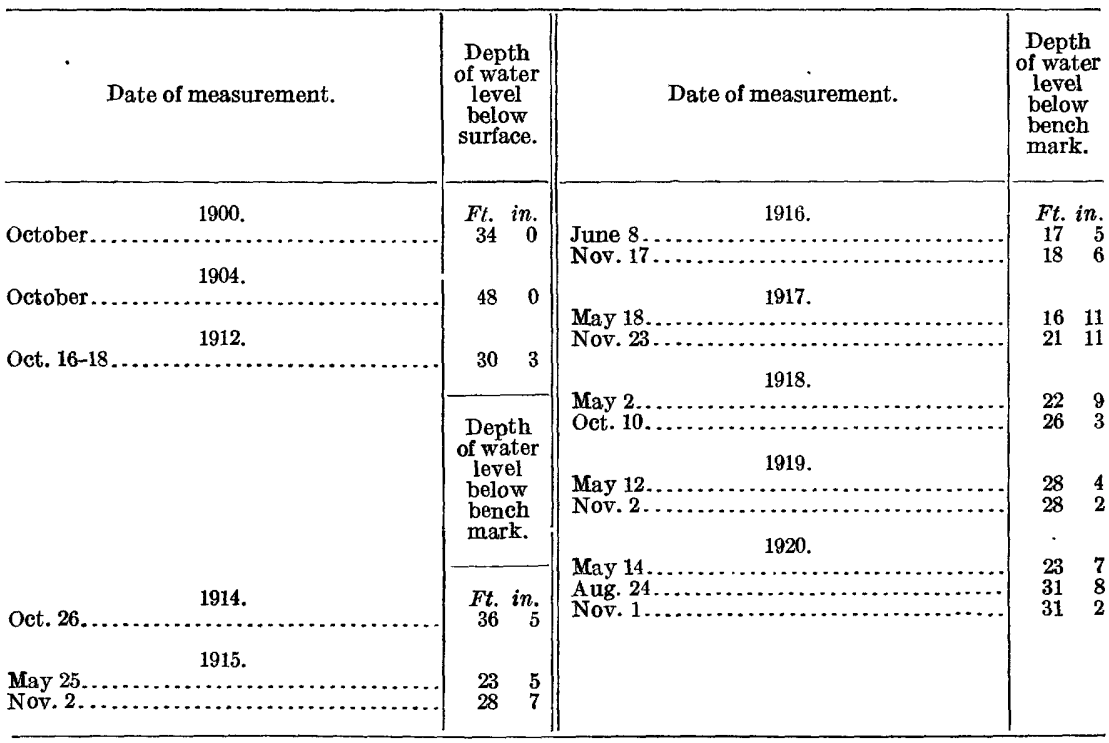

98. E. J. Stiles, $2 \frac{1}{2}$ miles northeast of San Bernardino, San Bernardino quadrangle.

[Well, 48 feet deep, 7-inch casing; sunk in 1898; method of hift, wind; use, domestic and stock. Bench mark: Top of casing at surface. Altitude of bench mark, $1,126.28$ feet above sea level. Well No. 318 , Water Supply Paper 142, p. 111.]

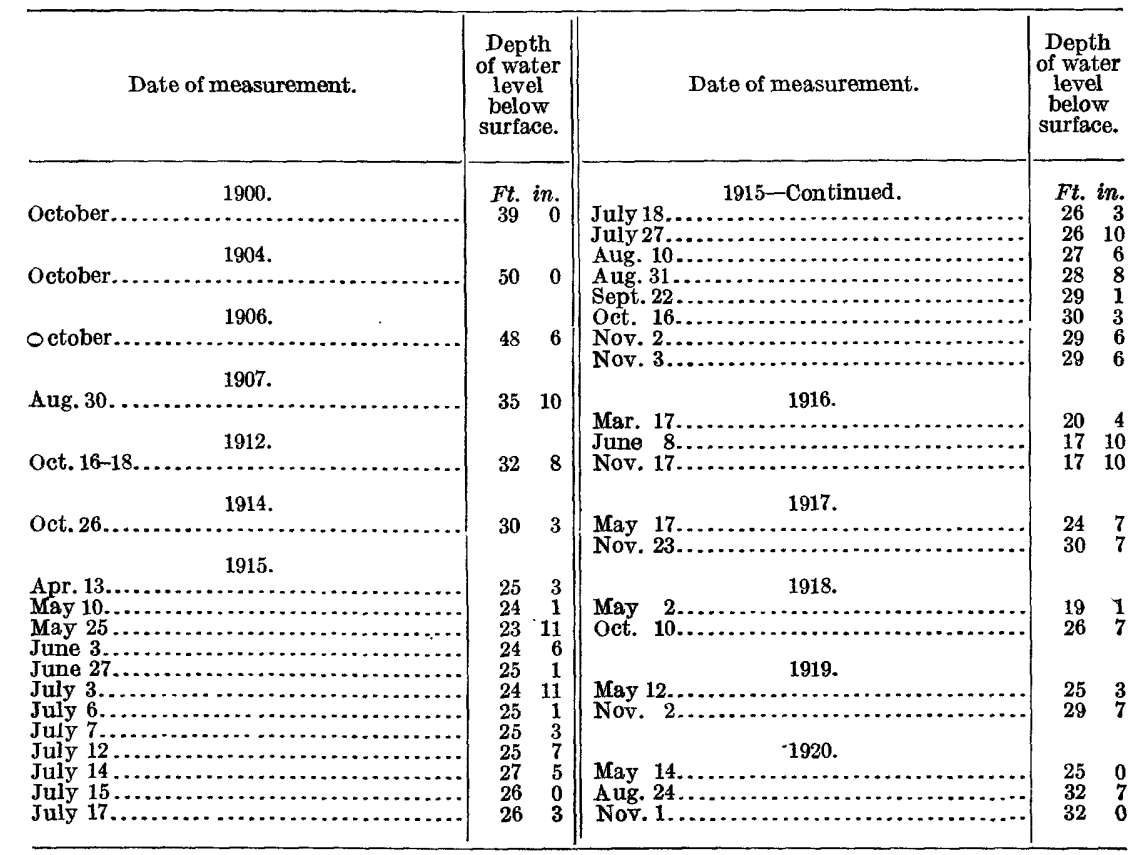


Records of water levels in the valley of southern California-Continued.

99a. W. R. Severence, three-fourths mile northeast of Valencia, San Bernardino quadrangle.

[Bench mark: Top of cast-iron cap, at surface. Companion well for Nos. 99 and 9\%b.]

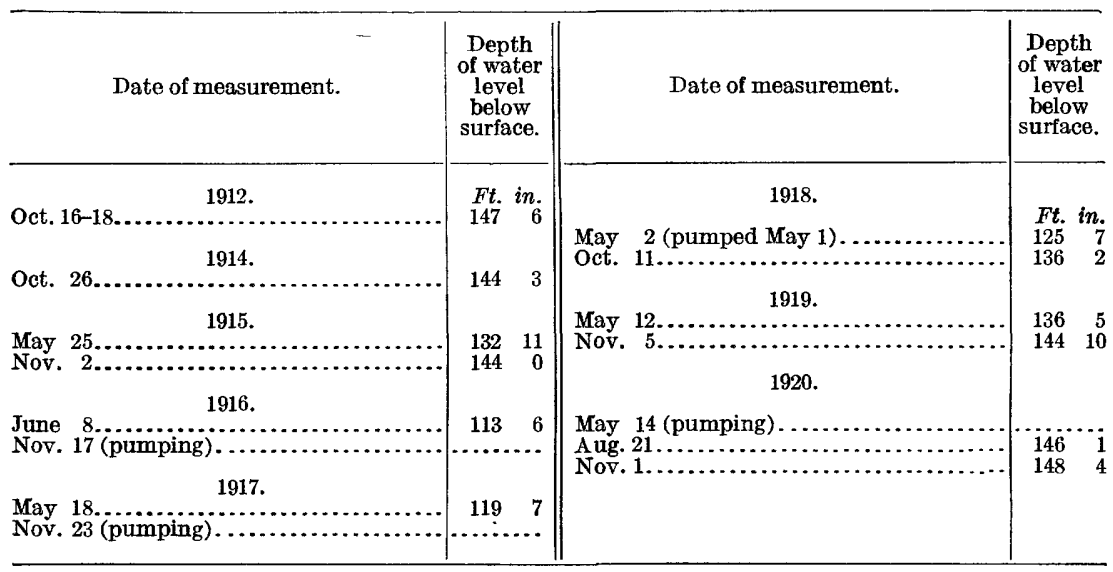

99b. M. S. Severence, half a mile northeast of Valencia, San Bernardino quadrangle.

[Altitude of bench mark, 1,251.3 feet above sea level. Companion well for Nos. 99 and 99a. Bench mark: Top of casing 1 foot 5 inches above surface.]

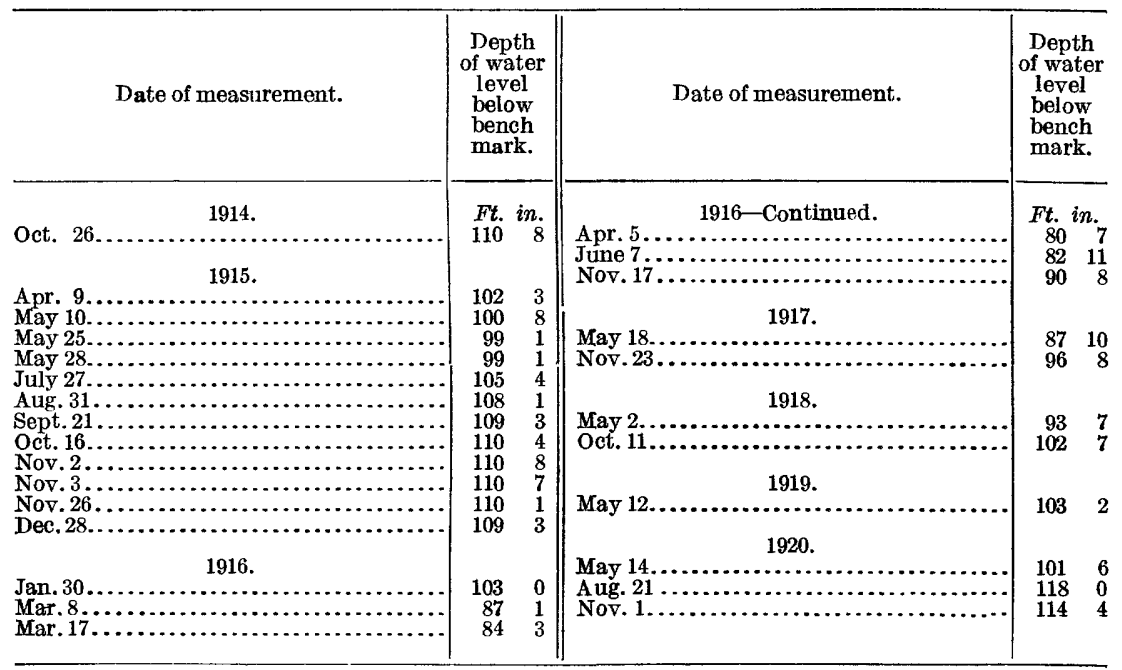

$1820^{\circ}-21-$ wsP $468-7$ 
Records of water levels in the valley of southern California-Continued.

100. Geo. M. Cooley, 2 miles southwest of Patton, San Bernardino quadrangle.

[Well, 66 feet deep, 7-inch casing; sunk in 1892; method of lift, wind; use, irrigation and domestic. Bench mark: Top of blocks over casing, 1 foot 4 inches above surface. Altitude of bench mark, 145.36 feet above sea level. Well No. 316, Water-Supply Paper 142, p. 110.]

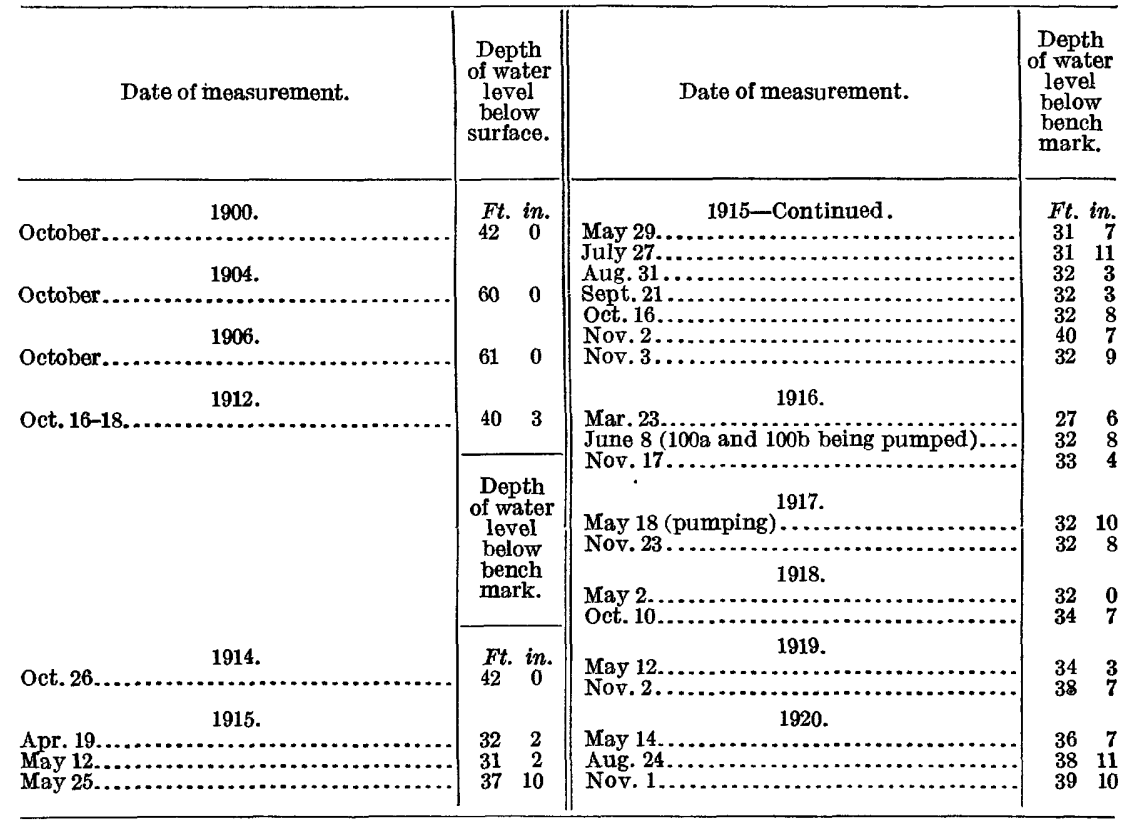

100a. Geo. M. Cooley, 2 miles southwest of Patton, San Bernardino quadrangle.

[Well, 80 feet deep, 11-inch casing; sunk in 1895: method of lift, gasoline engine; use, irrigation. Bench mark: Top of 8 by 8 blocks over casing, 1 foot above surface. Well No. 317, Water-Supply Paper 142, p. 110.]

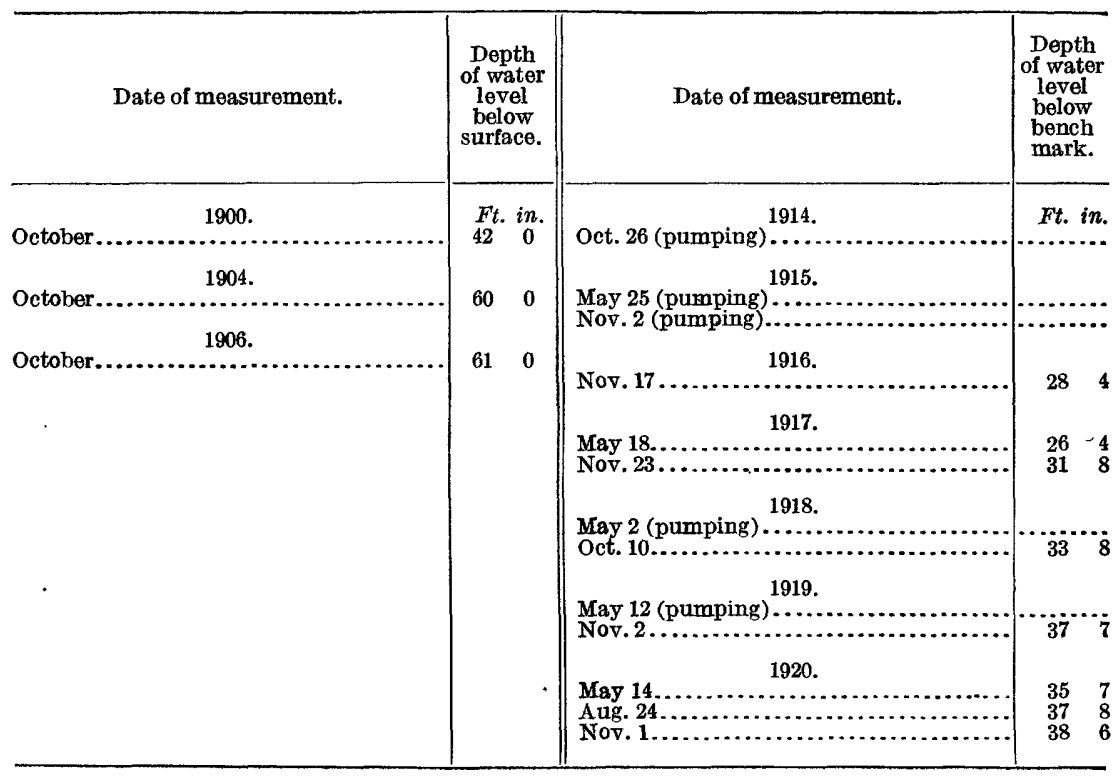


Records of water levels in the valley of southern California-Continued.

100b. George M. Cooley, 2 miles southwest of Patton, San Bernardino quadrangle.

[Well, 80 feet deep, 10-jnch casing; sunk in 1895; method of lift, cylinder pumps; use, irrigation. Bench mark: Top of block over casing, 1 foot above surface. Well No. 317a, Water-Supply Paper 142, p. 110.]

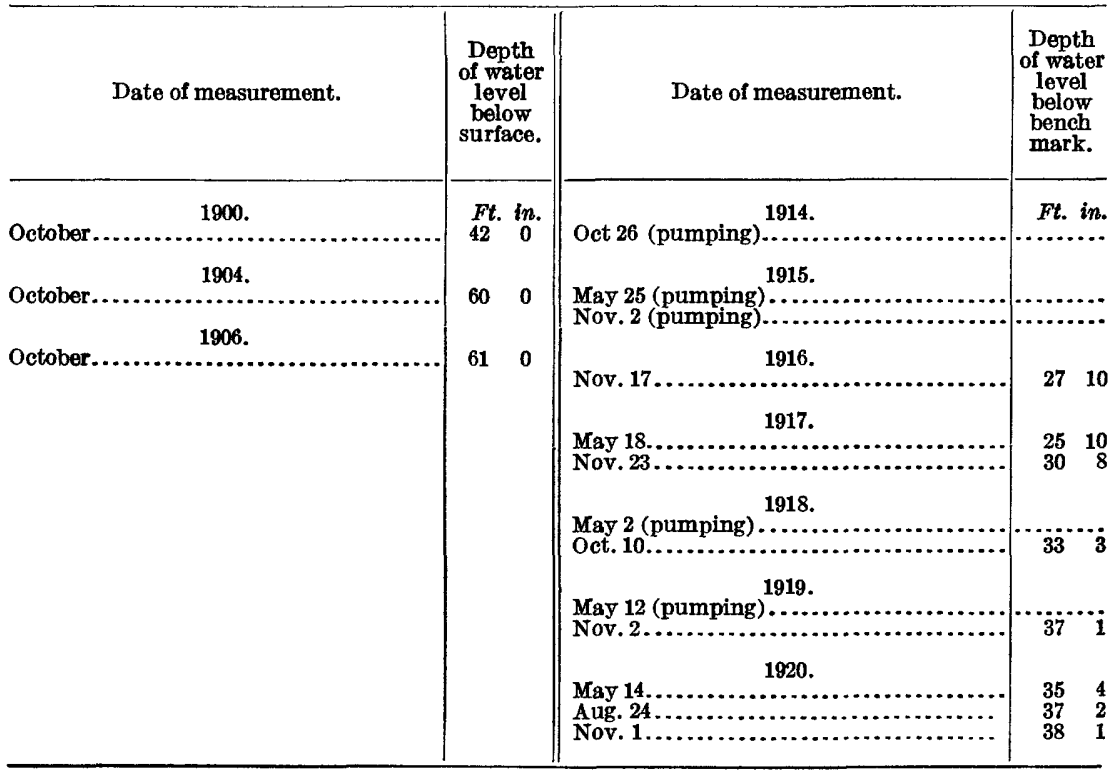

101. Riverside Trust Co. (formerly owned by C. Cutting), three-fourths mile northwest of Idlewild, San Bernardino quadrangle.

[Bored well, 170 feet deep, 7 inches in diameter; sunk in 1894; method of lift, eylinder pump and gasoline engine; use, domestic and irrigation. Well No. 104, Water-Supply Paper 142, p. 92.]

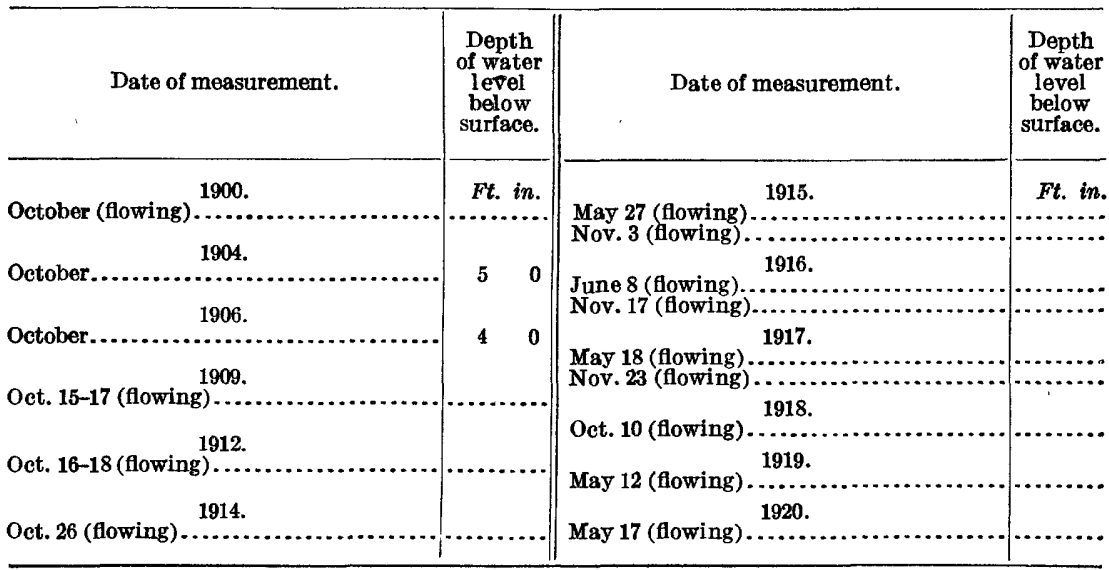


Records of water levels in the valley of southern California-Continued.

102. C. F. Crole (formerly owned by Jane C. Goodman), Harlem Springs, Redlands quadrangle.

[Bored well, 284 feet deep, 3 inches in diameter; sunk in 1894; method of lift, wind; use, irrigation and domestic. Bench mark: Top of blocks over casing, 1 foot 4 inches above surface. Well No. 350, WaterSupply Paper 142, p. 97.]

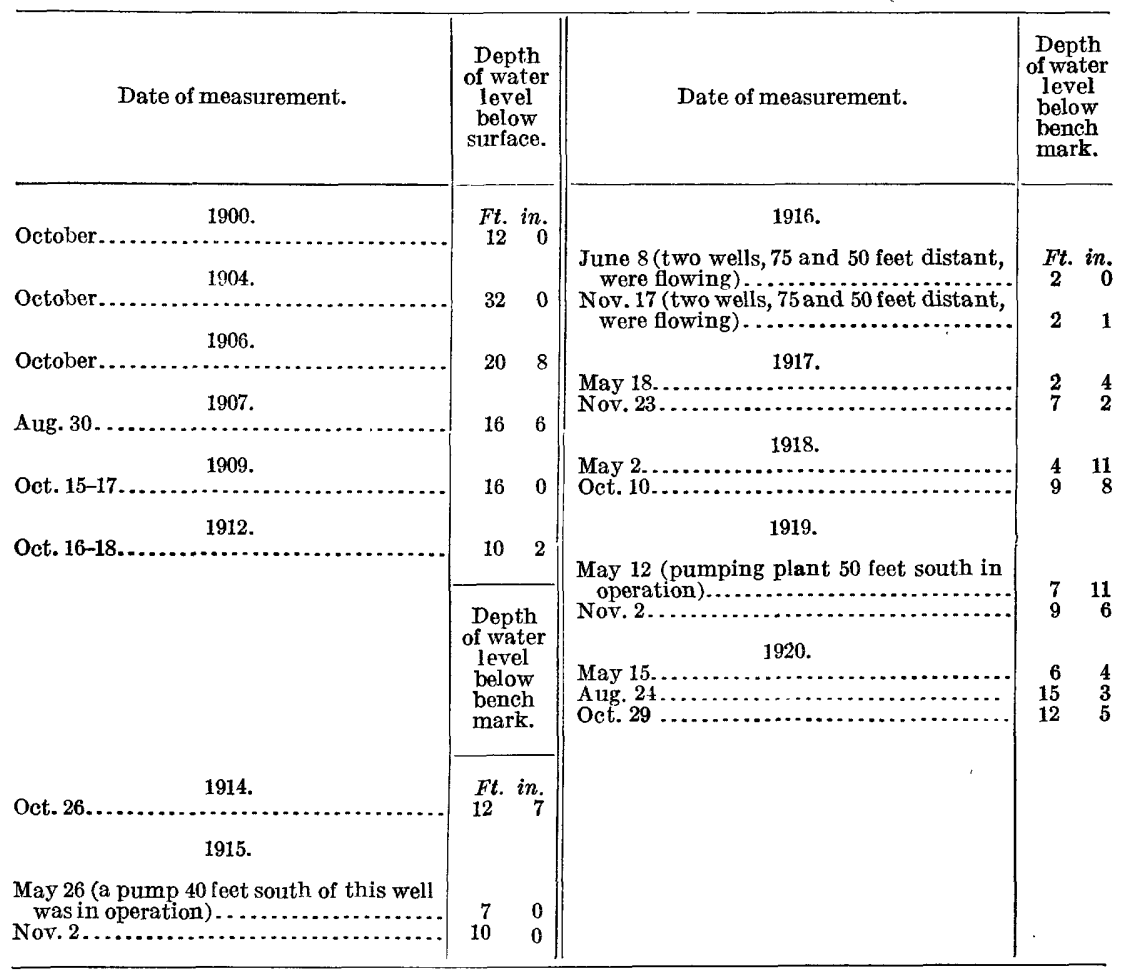

\section{Haws \& McKinley, Harlem Springs, Redlands quadrangle.}

[Bored well, 425 feet deep, 10 inches in diameter; sunk in 1897; mothod of lift, centrifugal pump and electric motor; use, irrigation. Bench mark: Top of 8 by 10 inch timber over curb, at surface. Altitude of bench mark, 1,145.09 feet above sea level. Well No. 343, Water-Supply Paper 142, p. 97.]

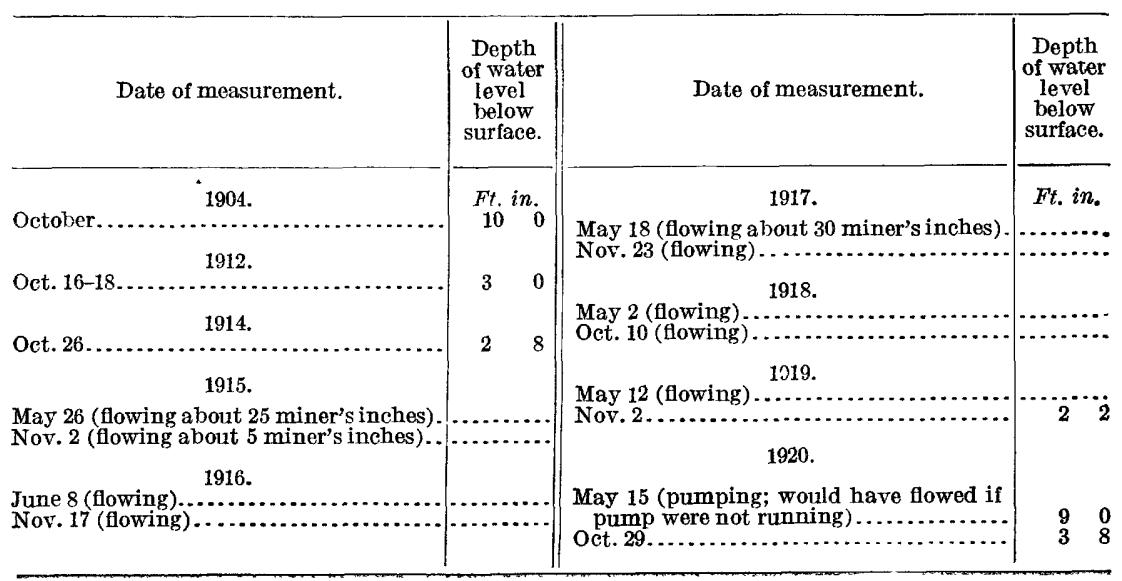


Records of water levels in the valley of southern California-Continued.

103a. Mrs. Haws, half a mile west of Harlem Springs, Redlands quadrangle.

[Bored well, 100 feet deep, 2 inches in diameter; sunk in 1898; method of lift, hand; use, domestic. Well No. 344, Water-Supply P'aper 142, p. 97.]

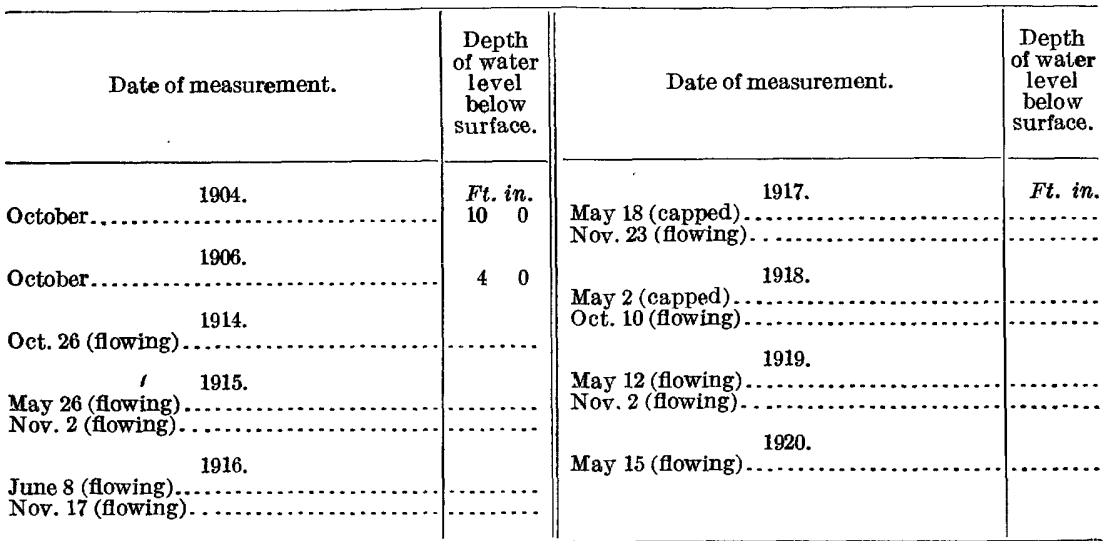

104. J. P. Scott, one-half mile southeast of Harlem Springs, Redlands quadrangle.

[Bench mark: Top of concrete, southeast side, 2.0 feet below ground level.]

\begin{tabular}{|c|c|c|c|}
\hline Date of measurement. & $\begin{array}{l}\text { Depth } \\
\text { of water } \\
\text { level } \\
\text { below } \\
\text { surface. }\end{array}$ & Date of measurement. & $\begin{array}{l}\text { Depth } \\
\text { of water } \\
\text { level } \\
\text { below } \\
\text { bench } \\
\text { mark. }\end{array}$ \\
\hline \multirow[t]{2}{*}{$\begin{array}{r} \\
\text { Oct. } 16-18 \ldots 12 .\end{array}$} & Ft. in. & $\begin{array}{l}\text { June } 8, \ldots \ldots \ldots \ldots \ldots \ldots \ldots \ldots \ldots \ldots \ldots \ldots \\
\text { Nov. } 17, \ldots \ldots \ldots \ldots \ldots \ldots \ldots \ldots \ldots \ldots \ldots \ldots\end{array}$ & $\begin{array}{rr}\text { Ft. } & \text { in. } \\
6 & 5 \\
10 & 0\end{array}$ \\
\hline & $\begin{array}{l}\text { Depth } \\
\text { of water } \\
\text { level } \\
\text { below } \\
\text { bench } \\
\text { mark. }\end{array}$ & 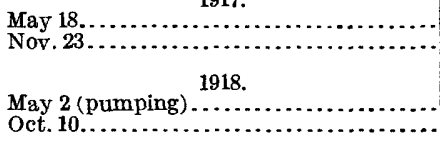 & $\begin{array}{l}11 \\
18 \\
21\end{array}$ \\
\hline Oct. $26 . . \ldots \ldots \ldots$ & $\begin{array}{l}\text { Ft. in } \\
23 \text { in }\end{array}$ & $\begin{array}{l}\text { May } 12 \ldots \ldots \ldots \ldots \ldots \ldots \ldots \\
\text { Nov. } 2 \ldots \ldots \ldots \ldots \ldots\end{array}$ & $\begin{array}{rr}17 & 1 \\
24 & 10\end{array}$ \\
\hline $\begin{array}{l}\text { May } 26 \ldots \ldots \ldots \ldots \ldots \ldots \ldots \ldots \ldots \\
\text { Nov. } 2 \ldots \ldots \ldots \ldots \ldots \ldots \ldots \ldots \ldots\end{array}$ & $\begin{array}{ll}13 & 1 \\
19 & 3\end{array}$ & 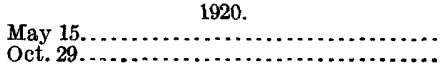 & $\begin{array}{l}15 \\
25\end{array}$ \\
\hline
\end{tabular}

105. L. H. Williams, three-fourths mile southeast of Harlem Springs, Redlands quadrangle.

[Bench mark: Top of casing, 1.6 feet above surface.]

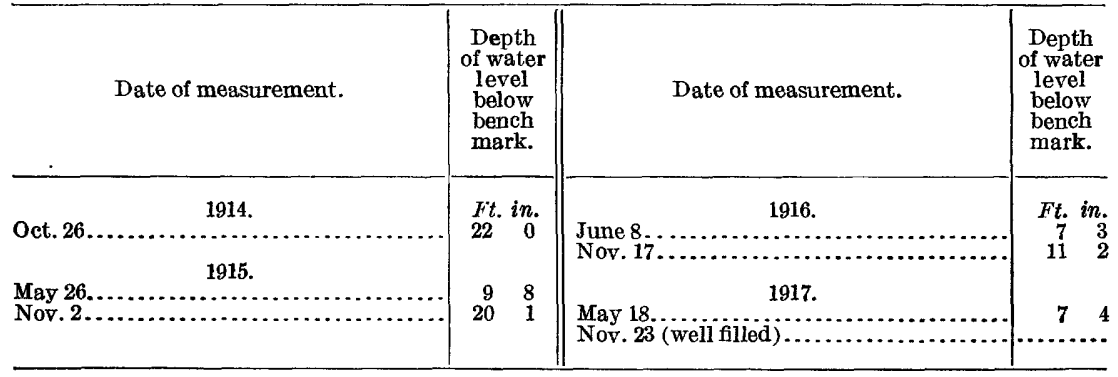


Records of water levels in the valley of southern California-Continued.

106. B. T. Esler (formerly owned by W. B. Robertson and G. J. Fowler), three-fourths mile southeast of Harlem Springs, Redlands quadrangle.

[Dug well, 55 feet deep, 5 feet in diameter; sunkin 1899; method of lift, wind; use, domestic. Bench mark: Top of sill on curb, at surface. Well No. 291, Water-Supply Paper 142, p. 95.]

\begin{tabular}{|c|c|c|c|}
\hline Date of measurement. & $\begin{array}{c}\text { Depth } \\
\text { of water } \\
\text { level } \\
\text { below } \\
\text { surface. }\end{array}$ & Date of measurement. & $\begin{array}{l}\text { Depth } \\
\text { of water } \\
\text { level } \\
\text { below } \\
\text { surface. }\end{array}$ \\
\hline October................ & Ft. in. & 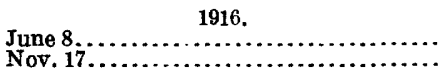 & $\begin{array}{cc}\text { Ft. } & \text { in. } \\
15 & 10 \\
21 & 1\end{array}$ \\
\hline October................. & 700 & Mav 18 & 16 \\
\hline October....... & & Nov. $23 . .$. & 27 \\
\hline Aug. 30..... & & (1) & $\begin{array}{rr}20 & 6 \\
30 & 10\end{array}$ \\
\hline Oct. $15-17 \ldots \ldots$. & 38 & May $12 \ldots \ldots \ldots \ldots \ldots \ldots \ldots \ldots$ & $\begin{array}{l}25 \\
36\end{array}$ \\
\hline Oct. 16-18.................. & 376 & 1920. & \\
\hline Oct. $26 \ldots \ldots \ldots \ldots \ldots \ldots \ldots$ & & 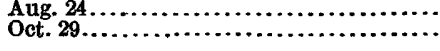 & $\begin{array}{ll}31 & 8 \\
33 & 7\end{array}$ \\
\hline 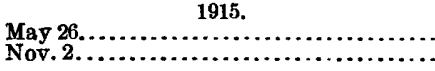 & $\begin{array}{rr}20 & 7 \\
30 & 11\end{array}$ & & \\
\hline
\end{tabular}

107. Pattee \&ye, 1 mile southeast of Harlem Springs, Redlands quadrangle.

[Dug, 6 by 8 feet, 50 feet; bored, 10-inch diameter, 100 feet; sunk in 1900; method of lift, rotary pump and electric motor; use, irrigation. Bench mark: Top of concrete curb, west side, 2.0 feet above surface. Altitude of bench mark, 1,198.41 feet above sea level. Well No. 290, Water-Supply Paper 142, p. 95.]

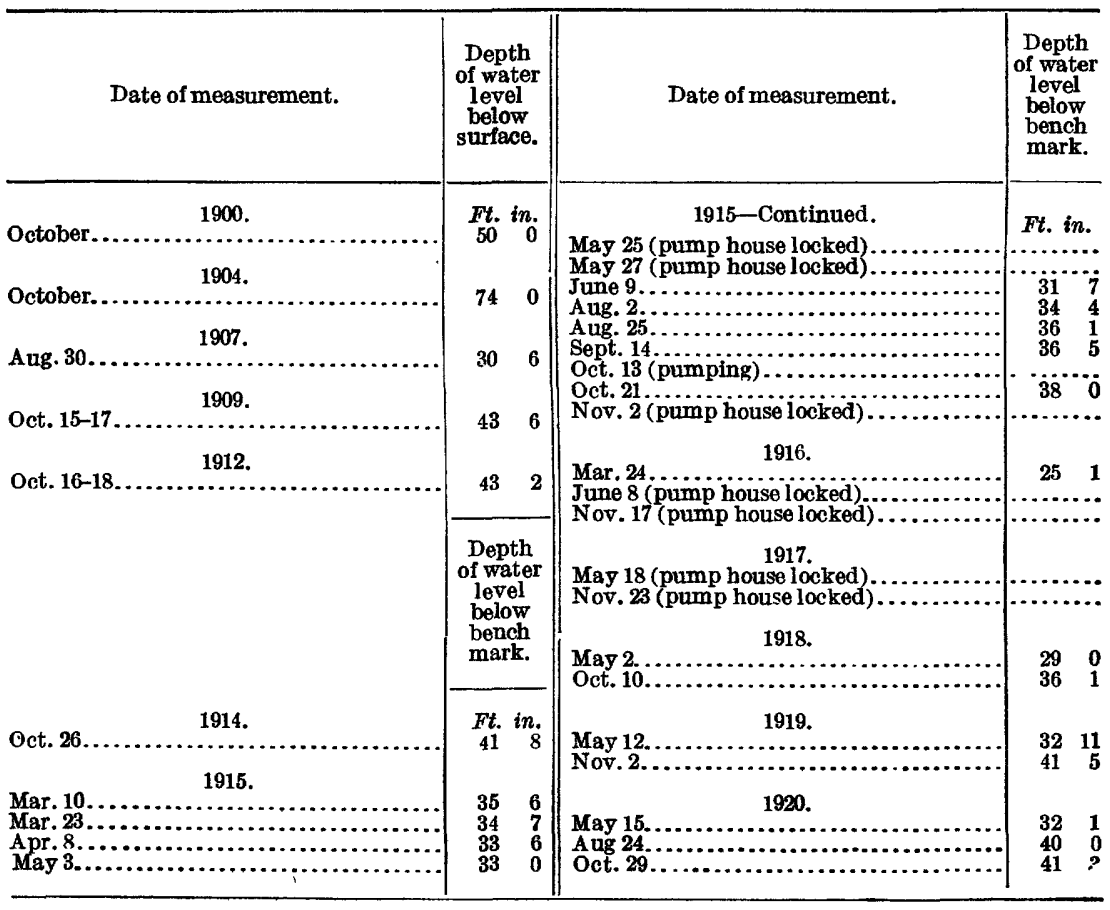


Records of water levels in the valley of southern California-Continued.

108. Mr. Slack, $1 \frac{1}{2}$ miles west of East Highlands, Redlands quadrangle.

[Bench mark: Top of casing, 2.0 feet above surface.]

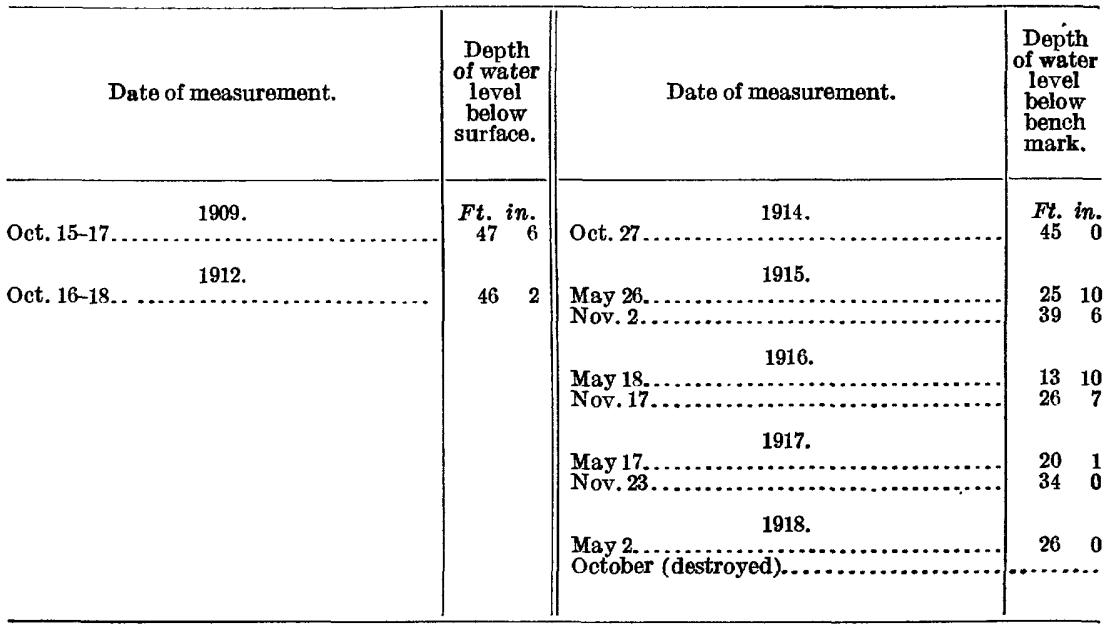

109. L. Lyons, $2 \frac{1}{2}$ miles northeast of Mentone, Redlands quadrangle.

[Dug well, 4 by 6 feet in cross section; sunk in 1900; method of lift, cylinder pump and gasoline engine; use, irrigation. Bench mark: Top of wooden curb, east side, at surface. Well No. 9, Water-Supply Paper 142, p. 88.]

\begin{tabular}{|c|c|c|c|}
\hline Date of measurement. & $\begin{array}{l}\text { Depth } \\
\text { of water } \\
\text { level } \\
\text { below } \\
\text { bench } \\
\text { mark. }\end{array}$ & Date of measurement. & $\begin{array}{l}\text { Depth } \\
\text { of water } \\
\text { level } \\
\text { below } \\
\text { bench } \\
\text { mark. }\end{array}$ \\
\hline 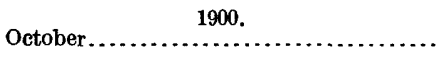 & Fit. in. & \begin{tabular}{c}
\multicolumn{1}{c}{1915.} \\
May $26 \ldots \ldots \ldots \ldots \ldots \ldots \ldots$
\end{tabular} & Ft. in. \\
\hline October.................................. & 130 & 1916. & \\
\hline 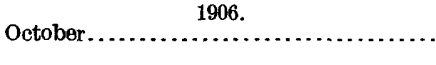 & 140 & Nov. $16 \ldots \ldots . . .19 .1$. & \\
\hline 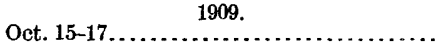 & 4 & 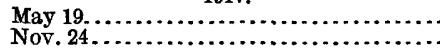 & $\begin{array}{l}6 \\
6\end{array}$ \\
\hline $\begin{array}{l}\text { Oct. 16-18 (a well } 30 \text { feet east was being } \\
\text { pumped) } \ldots \ldots \ldots \ldots \ldots \ldots \ldots \ldots \ldots \ldots \ldots \ldots\end{array}$ & 145 & $\begin{array}{l}1918 . \\
\text { May } 2 \text { (wrecked) } \ldots \ldots \ldots \ldots \ldots \ldots \ldots \ldots \ldots \ldots \ldots \ldots \ldots \ldots \\
\text { Oct. } 10 \text { (wrecked) } \ldots \ldots \ldots \ldots \ldots \ldots \ldots \ldots\end{array}$ & n...... \\
\hline $\begin{array}{c} \\
\text { Oct. } 27 . \ldots \ldots \ldots \ldots\end{array}$ & 7 & May 11 (wrecked) 1919. & \\
\hline
\end{tabular}


Records of water levels in the valley of southern California-Continued.

110. R. P. McIntosh, 3 miles northeast of Mentone, Redlands quadrangle.

[Dug well, 27 feet deep, 4 bv 4 feet in cross section; sunk in 1879; method of lift, wind; use, domestic. Bench mark: Top of wooden curb, west side, at surface. Well No. 5, Water-Supply Paper 142, p. 88.]

\begin{tabular}{|c|c|c|c|}
\hline Date of measurement. & $\begin{array}{c}\text { Depth } \\
\text { of water } \\
\text { level } \\
\text { below } \\
\text { surface. }\end{array}$ & Date of measurement. & $\begin{array}{l}\text { Depth } \\
\text { of water } \\
\text { level } \\
\text { below } \\
\text { surface. }\end{array}$ \\
\hline October............... & Ft. in. & 1915. & Ft. in. \\
\hline October............... & 170 & 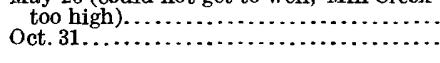 & $8{ }_{i}$ \\
\hline Oct. $16-18 \ldots \ldots \ldots \ldots \ldots \ldots$ & 210 & $\begin{array}{c}1916 . \\
\text { Tune } 7 \text { (January flood destroved well) }\end{array}$ & \\
\hline Oct. $27 \ldots \ldots \ldots \ldots \ldots \ldots \ldots$ & $14 \quad 11$ & & \\
\hline
\end{tabular}

110a. R. P. McIntosh, 3 miles northeast of Mentone, Redlands quadrangle.

[Companion well for No. 110. Situated 100 feet north of No. 110. Bench mark: Top of wooden curb, at surface.]

\begin{tabular}{|c|c|c|c|}
\hline Date of measurement. & $\begin{array}{l}\text { Depth } \\
\text { of water } \\
\text { level } \\
\text { below } \\
\text { surface. }\end{array}$ & Date of measurement. & $\begin{array}{l}\text { Depth } \\
\text { of water } \\
\text { level } \\
\text { below } \\
\text { surface. }\end{array}$ \\
\hline Oct. $27 \ldots \ldots \ldots \ldots \ldots$ & Ft. in. & $\begin{array}{c}1918 . \\
\ldots \ldots \ldots\end{array}$ & Ft. in. \\
\hline 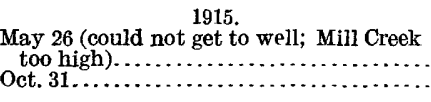 & $1 i{ }^{\prime \prime}$ & $\begin{array}{c}1919 . \\
\text { May } 11 \text { (small quantity of water flowing }\end{array}$ & 128 \\
\hline 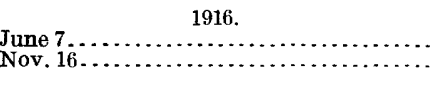 & $\begin{array}{ll}1 & 1 \\
4 & 0\end{array}$ & $\begin{array}{c}1920 . \\
\text { May } 15 \ldots \ldots \ldots \ldots \ldots \ldots \ldots\end{array}$ & 9 \\
\hline $\begin{array}{l}\text { May } 19, \ldots \ldots \ldots \ldots \ldots \ldots \ldots \\
\text { Nov. } 24, \ldots \ldots \ldots \ldots \ldots \ldots \ldots\end{array}$ & $\begin{array}{rr}4 & 3 \\
14 & 4\end{array}$ & Oct. $29 \ldots \ldots$ & 9 \\
\hline
\end{tabular}

111. Ward, Mills \& Co., 2 miles east of Mentone, Redlands quadrangle.

[Dug well, 125 feet deep, 4 by 6 feet in cross section; sunk in 1900; method of lift, gasoline engine. Bench mark: Top of well cover, south side, at surface. Well No. 2, Water-Supply Paper 142, p. 88.]

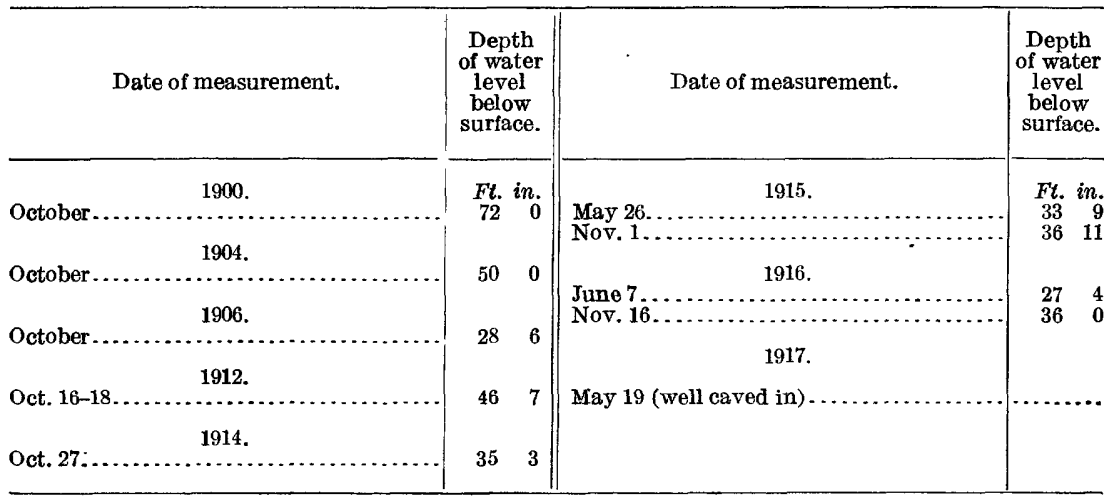


Records of water levels in the valley of southern California-Continued.

112. R. P. McIntosh, $1 \frac{1}{2}$ miles east of Mentone, Redlands quadrangle.

[Dug well, 103 feet deep, $4 \frac{1}{2}$ by $4 \frac{1}{2}$ feet in cross section; sunk in 1900; method of lift, cylinder pump and gasoline engine; use, irrigation. Bench mark: Top of curb, south side, at surface. Well No. 7, Water-Supply Paper 142, p. 88.]

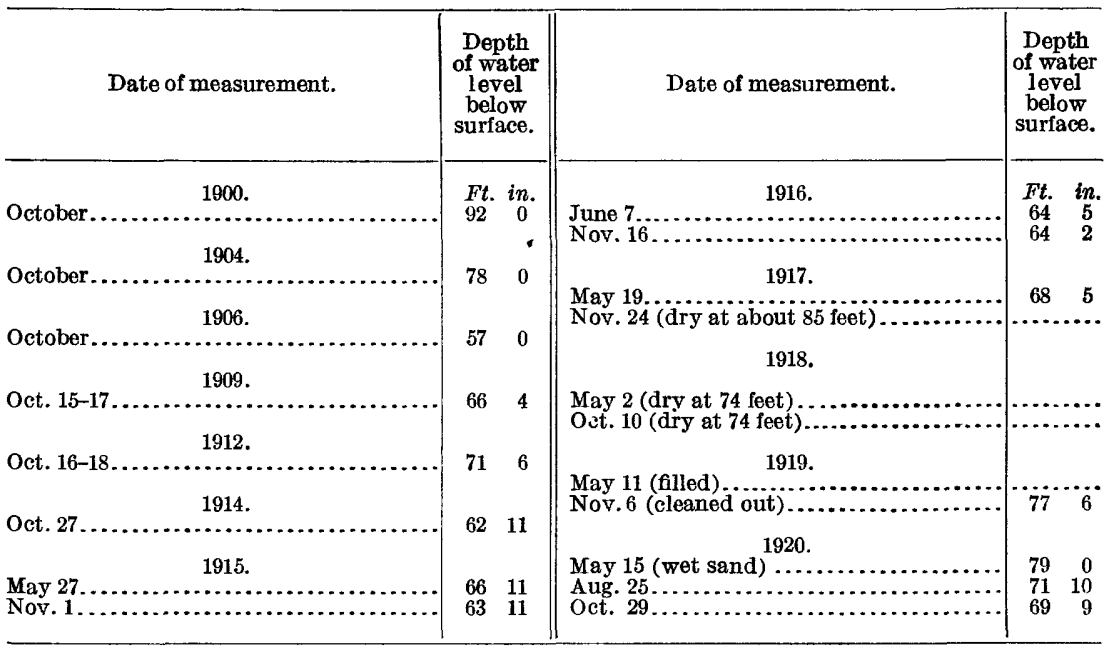

113. Garland estate, 2 miles east of Redlands, Redlands quadrangle.

[Bored well, 10 inches in diameter; sunk in 1900; method of lift, cylinder pump and gasoline engine; use, irrigation. Bench mark: Top of casing, 1.0 foot below surface. Well No. 28, Water-Supply Paper 142, p. 89.]

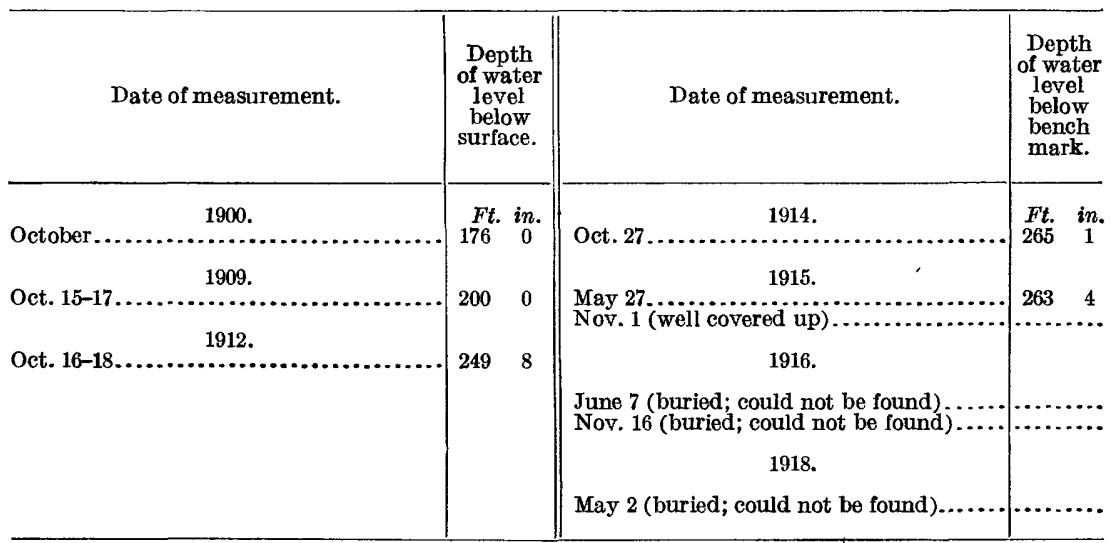


Records of water levels in the valley of southern California-Continued.

114. C. L. Hayes, Redlands, Redlands quadrangle.

[Bored well, 428 feet deep, 10 inches in diameter; sunk in 1899; method of lift, cylinder pump and gasoline engine; use, irrigation. Bench mark: Top of easing, 8.0 feet below surface. Well No. 42, Water-Supply Paper 142, p. 89.]

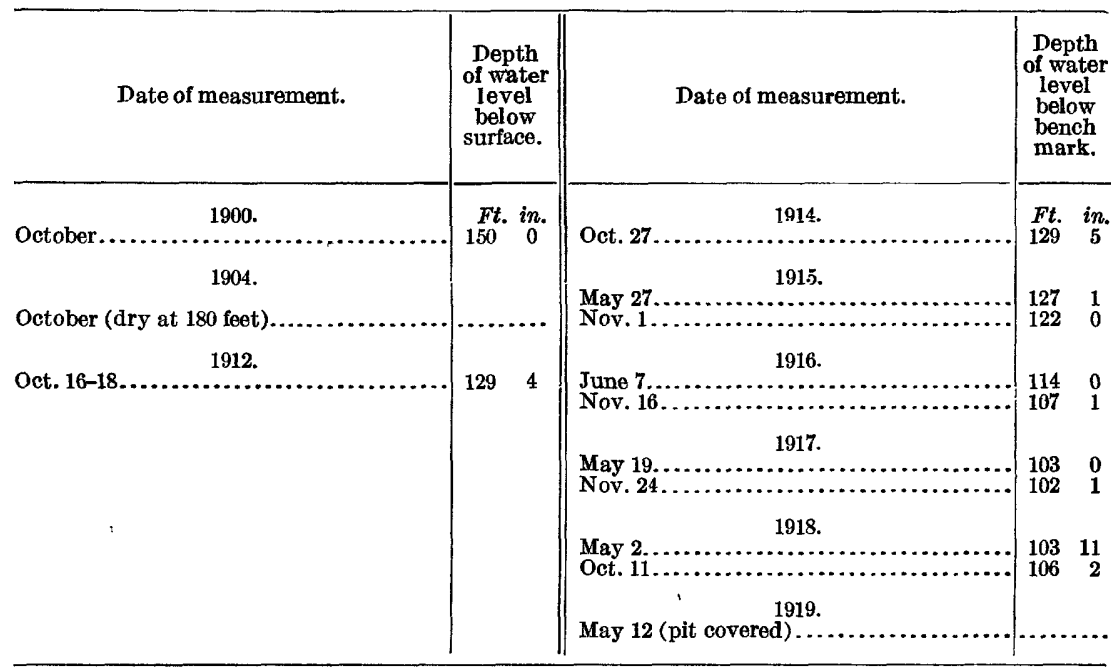

115. Willis Miller, 1 mile northeast of Redlands, Redlands quadrangle.

[Bored well, 123 feet deep, 7 inches in diameter; sunk in 1893; method of lift, wind; use, domestic. Bench mark: Top of casing, 1 foot 10 inches above surface. Altitude of bench mark $1,289.97$ feet above sea level. Well No. 102, Water-Supply Paper 142, p. 91. ]

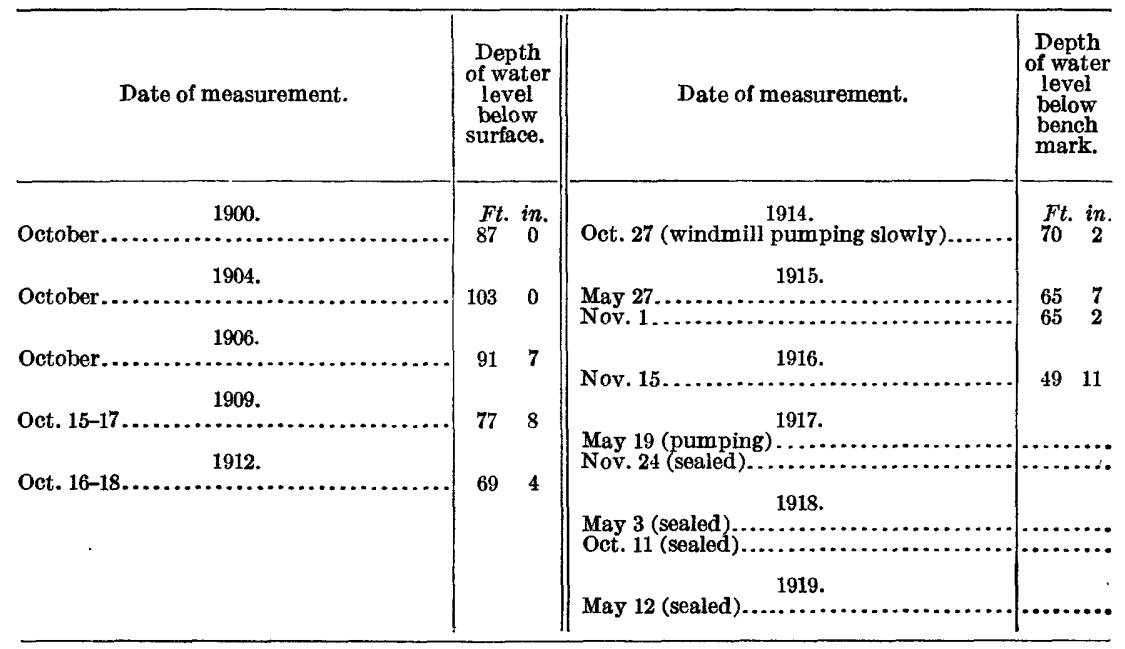


Records of water levels in the valley of southern California-Continued.

116. J. F. Boyd, 2 miles northwest of Redlands, Redlands quadrangle.

(Two bored wells respectively 100 and 110 feet deep; 10 inches in diameter; sunk in 1896; not used. Bench mark: Top of casing, level with surface. Well No. 123, Water-Supply Paper 142, p. 93.]

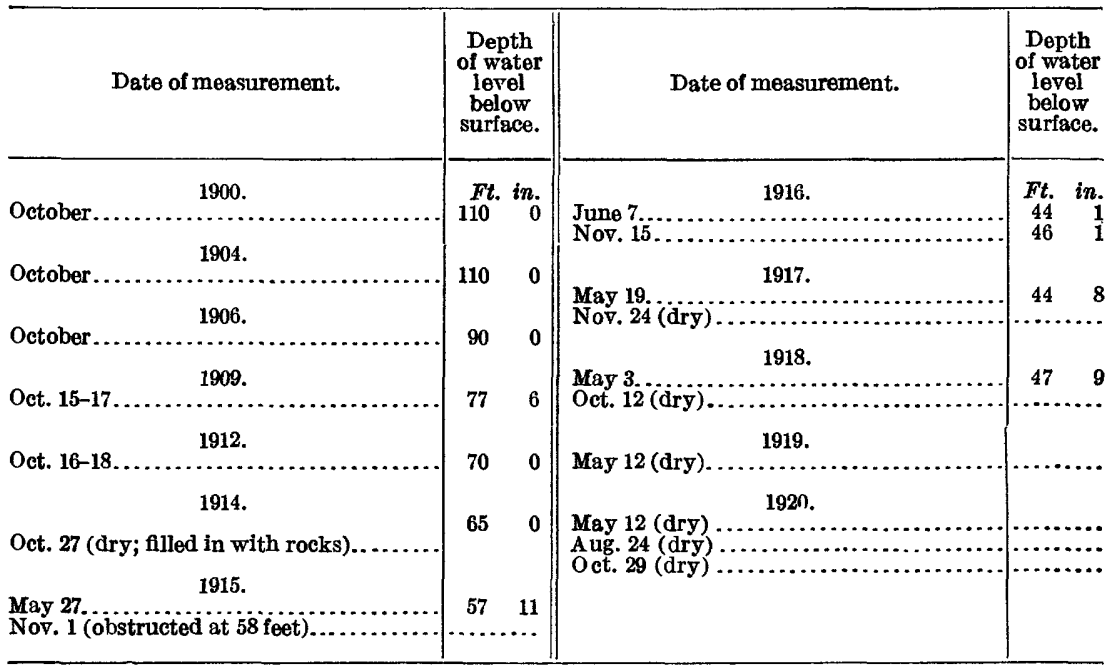

117. S. Ronzone, 2 miles northwest of Redlands, Redlands quadrangle.

[Bored well, 98 feet deep, 9 inches in diameter; sunk in 1899; method of lift, wind; use, domestic and irrigation. Bench mark: Top of casing, 2 feet 7 inches above surface. Altitude at bench mark, 1,255.71 feet above sea level. Well No. 117, Water-Supply Paper 142, p. 92.]

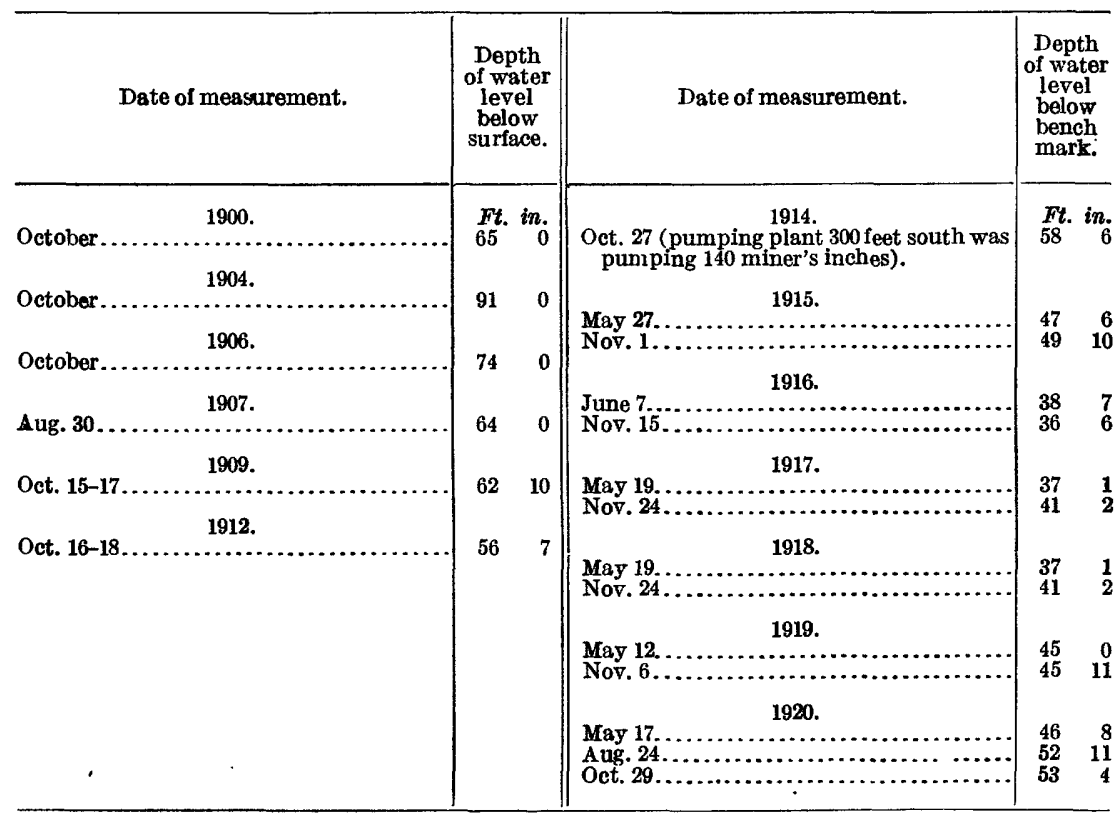


Records of water levels in the valley of southern California-Continued.

118. M. R. Gay, $2 \frac{1}{2}$ miles northwest of Redlands, Redlands quadrangle.

[Well, 200 feet deep, situated 600 feet south of well No. 120, Water-Supply Paper 142, p. 92. For measurements of No. 120 prior to October, 1912, see table on page 120. Bench mark: Top of casing cap, 1 foot 4 inches above surface.]

\begin{tabular}{|c|c|c|c|}
\hline Date of measurement. & $\begin{array}{l}\text { Depth } \\
\text { of water } \\
\text { level } \\
\text { below } \\
\text { surface. }\end{array}$ & Date of measurement. & $\begin{array}{l}\text { Depth } \\
\text { of water } \\
\text { level } \\
\text { below } \\
\text { bench } \\
\text { mark. }\end{array}$ \\
\hline \multirow[t]{2}{*}{ Oct. $16-18 \ldots \ldots \ldots$} & $\begin{array}{ll}F t . & \text { in. } \\
54 & 10\end{array}$ & 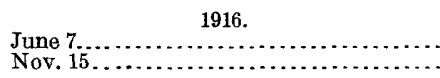 & $\begin{array}{lr}\text { Ft. } & \text { in. } \\
34 & 5 \\
34 & 10\end{array}$ \\
\hline & $\begin{array}{l}\text { Depth } \\
\text { of water } \\
\text { level } \\
\text { below } \\
\text { bench } \\
\text { mark. }\end{array}$ & $\begin{array}{l}1917 . \\
\text { May } 19 \text { (pumping) } \ldots \ldots \ldots \ldots \\
\text { Nov. } 24 \ldots \ldots \ldots \ldots \ldots \ldots \ldots \\
\text { May } 3 \text { (pumping) } 1918 . \ldots \ldots \ldots \ldots \\
\text { Oct. } 11 \ldots \ldots \ldots \ldots \ldots \ldots \ldots \ldots\end{array}$ & $\begin{array}{l}36 \\
\\
41^{2}\end{array}$ \\
\hline Oct. $27 . . . .$. & $\underset{52}{\text { Ft. in. }}$ & $\begin{array}{l}1919 . \\
\text { May } 12 \text { (pumping; air lift).......... } \\
\text { Nov. } 6 \ldots \ldots \ldots \ldots \ldots \ldots \ldots \ldots\end{array}$ & $45{ }_{4}$ \\
\hline $\begin{array}{l}\text { May } 27 \ldots \ldots \ldots \ldots \ldots \\
\text { Nov, } 1 \text { (pumping with air lift).... }\end{array}$ & $\begin{array}{rr}39 & 8 \\
\cdots & \end{array}$ & $\begin{array}{l}1920 . \\
\text { May } 17 \text { (pumping) } \ldots \ldots \ldots \ldots \ldots \ldots \ldots \ldots \ldots \\
\text { Aug. } 25 \text { (pumping) } \ldots \ldots \ldots \ldots \ldots \ldots \ldots \ldots \ldots \\
\text { Oct. } 29 \text { (pumping) } \ldots \ldots \ldots \ldots \ldots \ldots \ldots\end{array}$ & (n. \\
\hline
\end{tabular}

119. Emmet Martin (formerly owned by William Lindenberg), $2 \frac{1}{1}$ miles northwest of Redlands, Redlands quadrangle.

[Bored well, 93 feet deep, 7 inches in diameter; sunk in 1893; method of lift, wind; use, irrigation and domestic. Bench mark: Top of casing, 1 foot 7 inches above surface. Altitude of bench mark, 1,205.50 feet above sea level. Well No. 124, Water-Supply Paper 142, p. 93.]

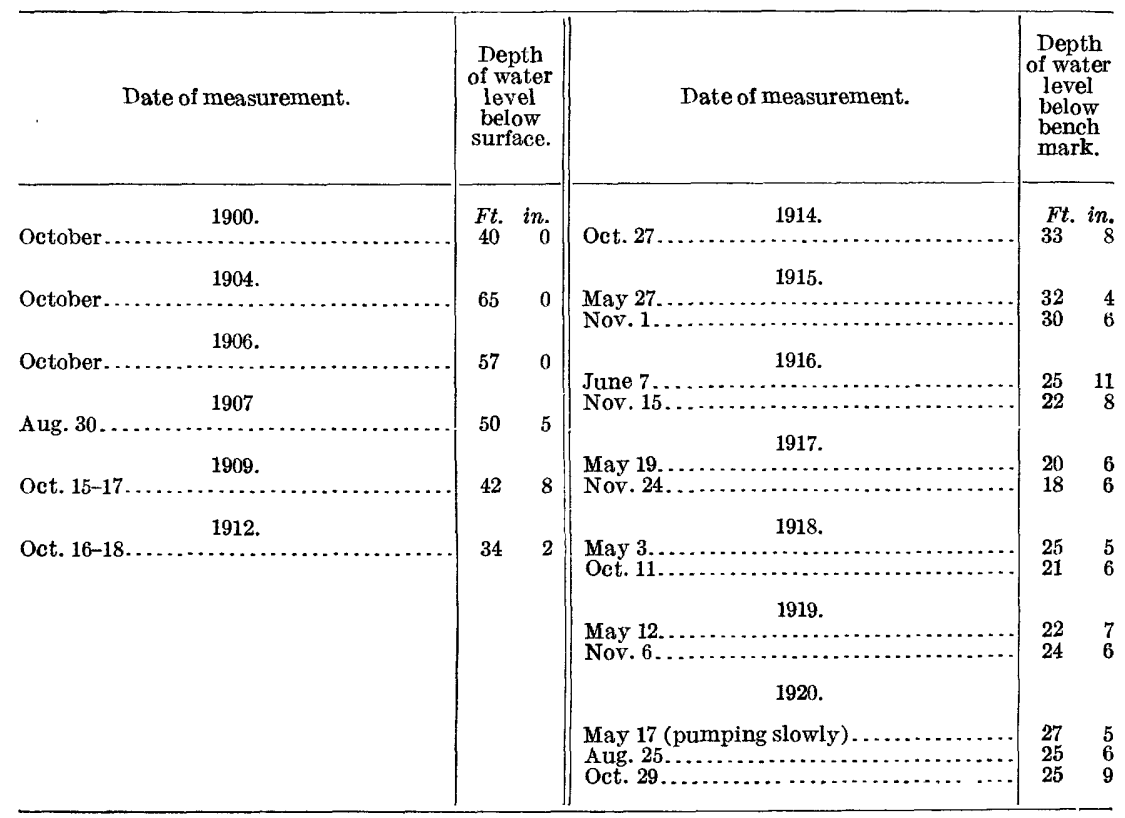


'Records of water levels in the valley of southern California-Continued.

120. E. Norwood (formerly owned by A. Gregory), $1 \frac{1}{2}$ miles northwest of Redlands, Rediands quadrangle.

[Bored well, 100 feet deep, 7 inches in diameter; sunk in 1890; method of lift, wind; use, domestic. Bench mark: Top of casing, 3.0 feet above surface. Altitude of bench mark, 1,236.54 feet above sea level. Well No. 113, Water-Supply Paper 142, p. 92.]

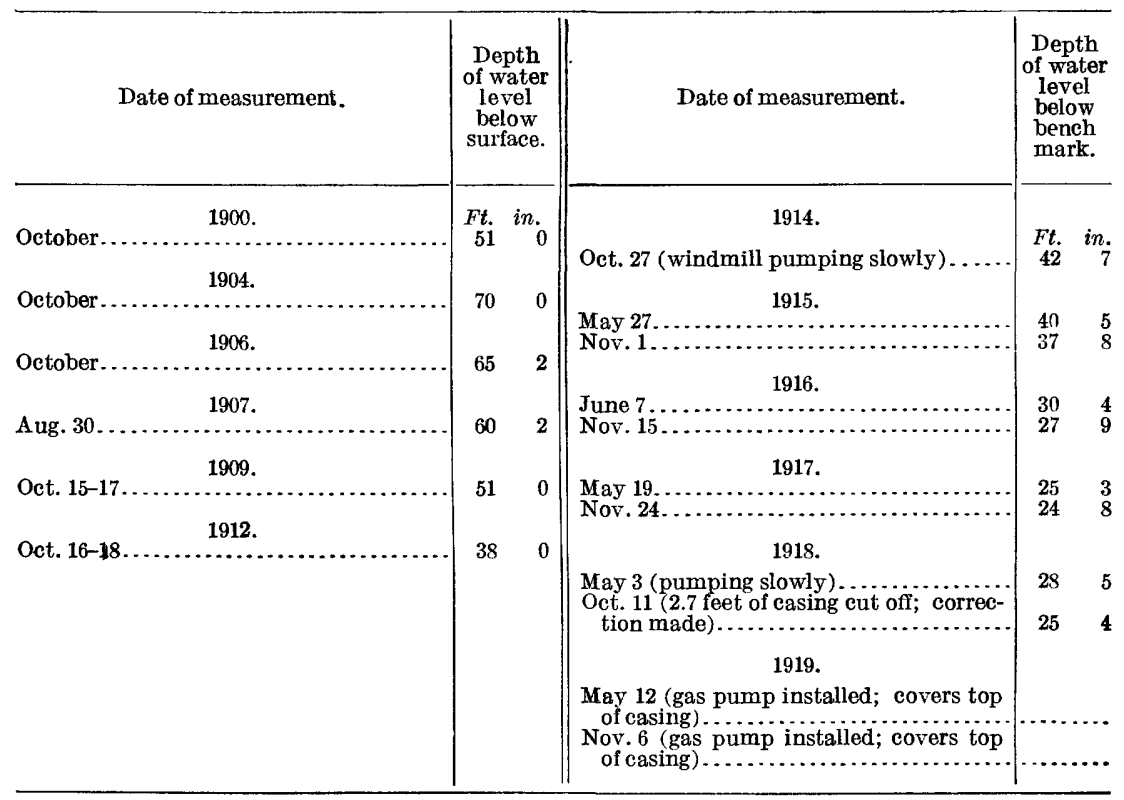

121. J. Champion (formerly owned by C. A. Shaw), $1 \frac{1}{2}$ miles northwest of Redlands, Redlands quadrangle.

[Bored well, 96 feet deep, 7 inches in diameter; sunk in 1893; method of lift, wind; use, domestic and irrigation. Bench mark: Top of casing, 10 inches above surface. Altitude of bench mark, 1,259.57 feet above sea level. Well No. 109, Water-Supply Paper 142, p. 92.]

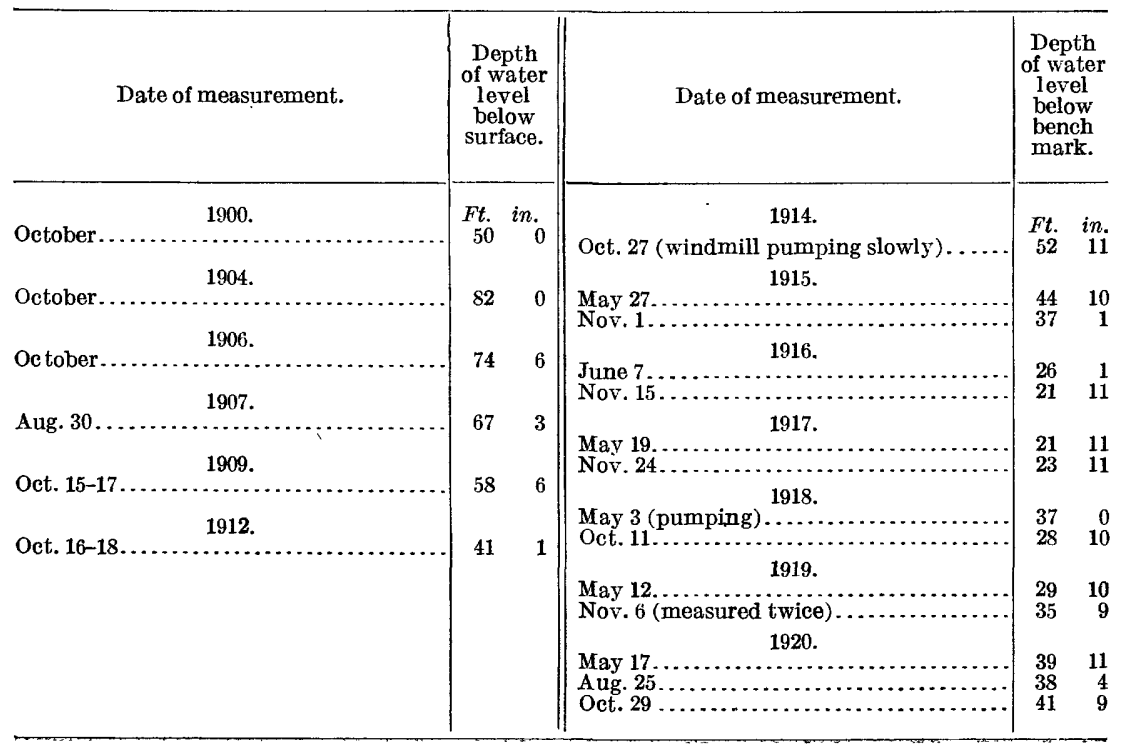


Records of water levels in the valley of southern California-Continued:

122. W. A. Nichols, $1 \frac{1}{2}$ miles west of Redlands, Redlands quadrangle.

[Bored well, 122 feet deep, 7 inches in diameter; sunk in 1891; method of lift, hand pump; use, domestic. Bench mark: Top of casing, 2.0 feet above surface. Weli No. 94, Water-Supply Paper 142, p. 91.]

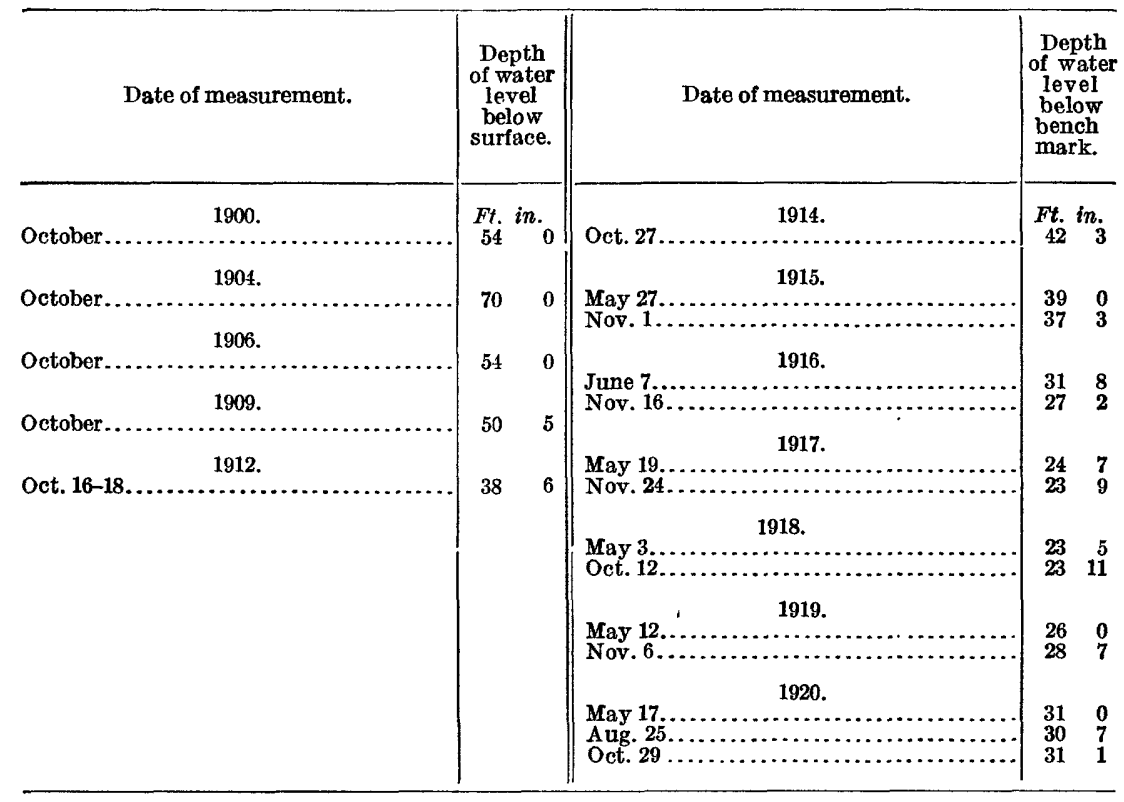

122a. W. A. Nichols, $1 \frac{1}{4}$ miles west of Redlands, Redlands quadrangle.

[Bored well, 284 feet deep, 10 inches in diameter; method of lift, cylinder pump and gasoline engine; use, irrigation. Bench mark: Top of metal casing, at surface. Well No. 95, Water-Supply Paper 142, p. 91. Companion well for No. 122. Record kept by owner; can be measured only when pump rods are pulled.j

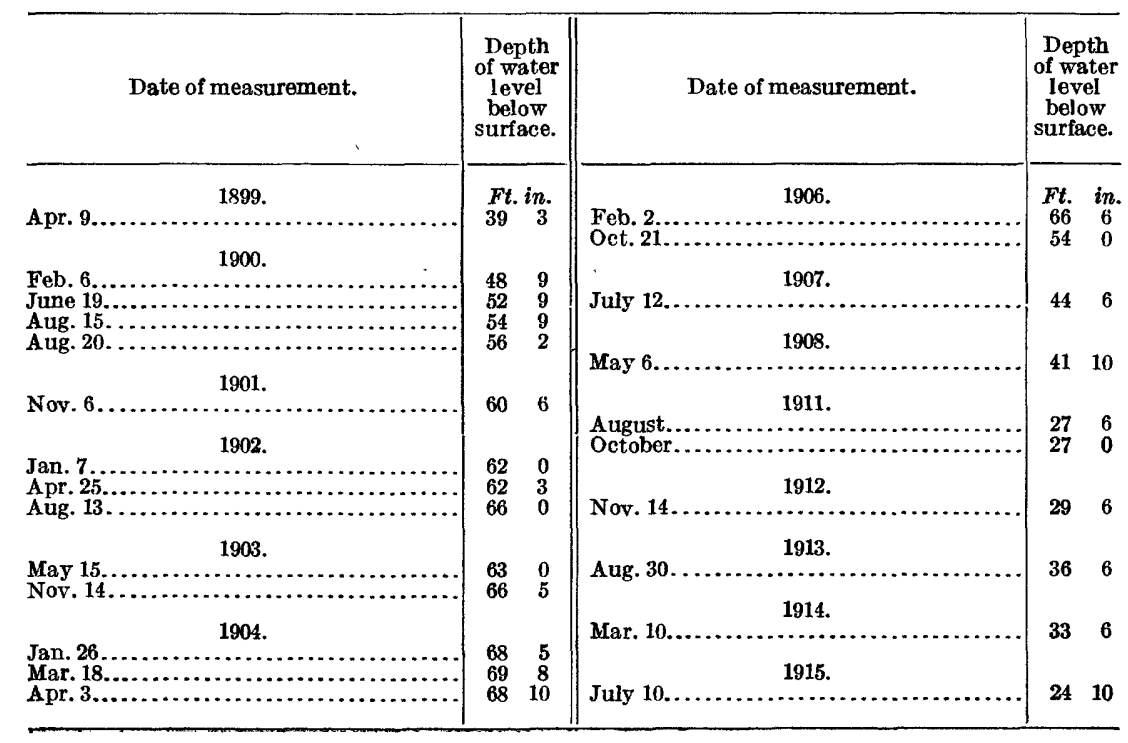


Records of water levels in the valley of southern California-Continued.

123. Mrs. S. W. Sylvera, $1 \frac{1}{2}$ miles southwest of Redlands, Redlands quadrangle.

[Bored well, 90 feet deep, 7 inches in diameter; sunk in 1891; method of lift, wind; use, domestic. Bench mark: Top of blocks over casing, 1 foot above surface. Well No. 80, Water-Supply Paper 142, p. 91.]

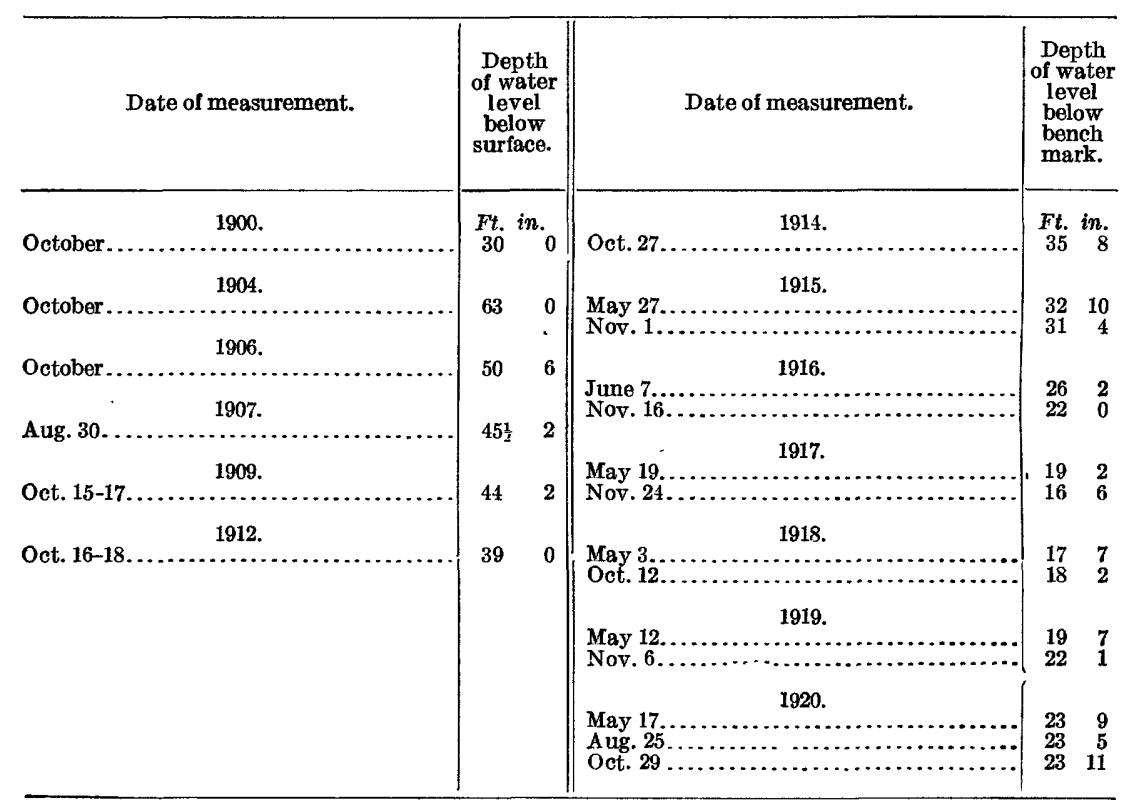

124. O. J. Fisk (formerly owned by S. Mansfield), three-fourths mile northeast of Bryn Mawr, Redlands quadrangle.

[Bored well, 109 feet deep, 7 inches in diameter; sunk in 1890; method of hift, wind; use, domestıc and irrigation. Bench mark: Top of casing, at surface. Well No. 83, Water-Supply Paper 142, p. 91.]

\begin{tabular}{|c|c|c|c|}
\hline Date of measurement. & $\begin{array}{l}\text { Depth } \\
\text { of water } \\
\text { level } \\
\text { below } \\
\text { surface. }\end{array}$ & Date of measurement. & $\begin{array}{l}\text { Depth } \\
\text { of water } \\
\text { level } \\
\text { below } \\
\text { surface. }\end{array}$ \\
\hline October ..................... & Ft. in. & May $27 \ldots \ldots \ldots \ldots \ldots \ldots \ldots$ & Ft. in. \\
\hline October.................... & $50 \quad 0$ & 1916. & \\
\hline October................... & $47 \quad 10$ & $\begin{array}{c}\text { Nov. } 16 \ldots \ldots \ldots \ldots . . . \\
1917 .\end{array}$ & 19 \\
\hline $\begin{array}{l}1907 . \\
\text { Aug. } 30 \ldots \ldots \ldots \ldots \ldots \ldots \ldots . . .\end{array}$ & $43 \quad 10$ & 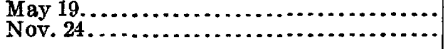 & $\begin{array}{l}16 \\
16\end{array}$ \\
\hline Oct. $15-17 \ldots \ldots \ldots \ldots \ldots \ldots$ & 40 & 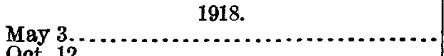 & $14 \quad 11$ \\
\hline $\begin{array}{c}1912 . \\
\text { Oct. } 16-18 \ldots \ldots \ldots \ldots \ldots \ldots \ldots \ldots \ldots \ldots \ldots \\
1914 .\end{array}$ & 318 & $\begin{array}{c}1919 . \\
\text { May } 12 \ldots \ldots \ldots \ldots \ldots \ldots \ldots \ldots \ldots \ldots \ldots \ldots \ldots \ldots \ldots \ldots \ldots\end{array}$ & $\begin{array}{ll}16 & 6 \\
18 & 6\end{array}$ \\
\hline 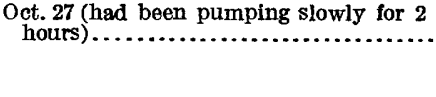 & $31 \quad 11$ & 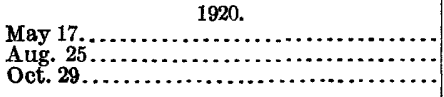 & $\begin{array}{rr}18 & 1 \\
18 & 0 \\
18 & 11\end{array}$ \\
\hline
\end{tabular}


Records of water levels in the valley of southern California-Continued.

125. H. Bermudas, Bryn Mawr, Redlands quadrangle.

[Bored well, 112 feet deep, 7 inches in diameter; sunk in 1893; method of lift, windmill; use, domestic. Bench mark: Top of casing, 1 foot 10 inches above surface. Well No. 56, Water-Supply Paper 142, p. 90.]

\begin{tabular}{|c|c|c|c|}
\hline Date of measurement. & $\begin{array}{l}\text { Depth } \\
\text { of water } \\
\text { level } \\
\text { below } \\
\text { surface. }\end{array}$ & Date of measurement. & $\begin{array}{l}\text { Depth } \\
\text { of water } \\
\text { level } \\
\text { below } \\
\text { bench } \\
\text { mark. }\end{array}$ \\
\hline 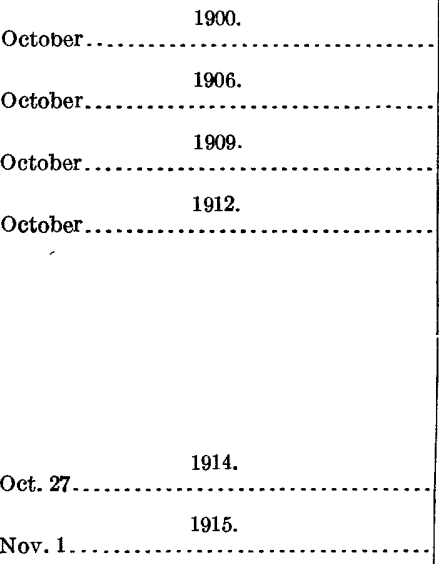 & 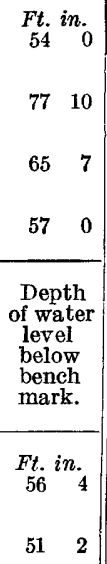 & 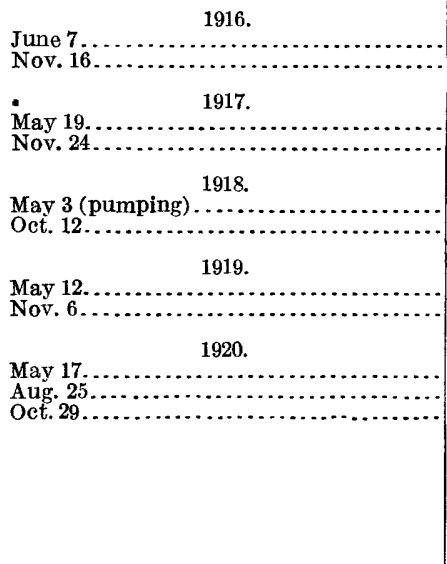 & $\begin{array}{rr}\text { Ft. } & \text { in. } \\
46 & 2 \\
45 & 3 \\
& \\
& \\
49 & 7 \\
41 & 9 \\
& \\
& \\
40 & 6 \\
& \\
& \\
39 & 10 \\
43 & 2 \\
& \\
& \\
43 & 4 \\
43 & 9 \\
44 & 1\end{array}$ \\
\hline
\end{tabular}

126. A. C. Fowler, Bryn Mawr, Redlands quadrangle.

[Bored well, 170 feet deep, 9 inches in diameter; sunk in 1898; method of lift, windmill; use, domestic. Bench mark: Top of casing, 6 inches above surface. Well No. 45, Water-Supply Paper 142, p. 89.]

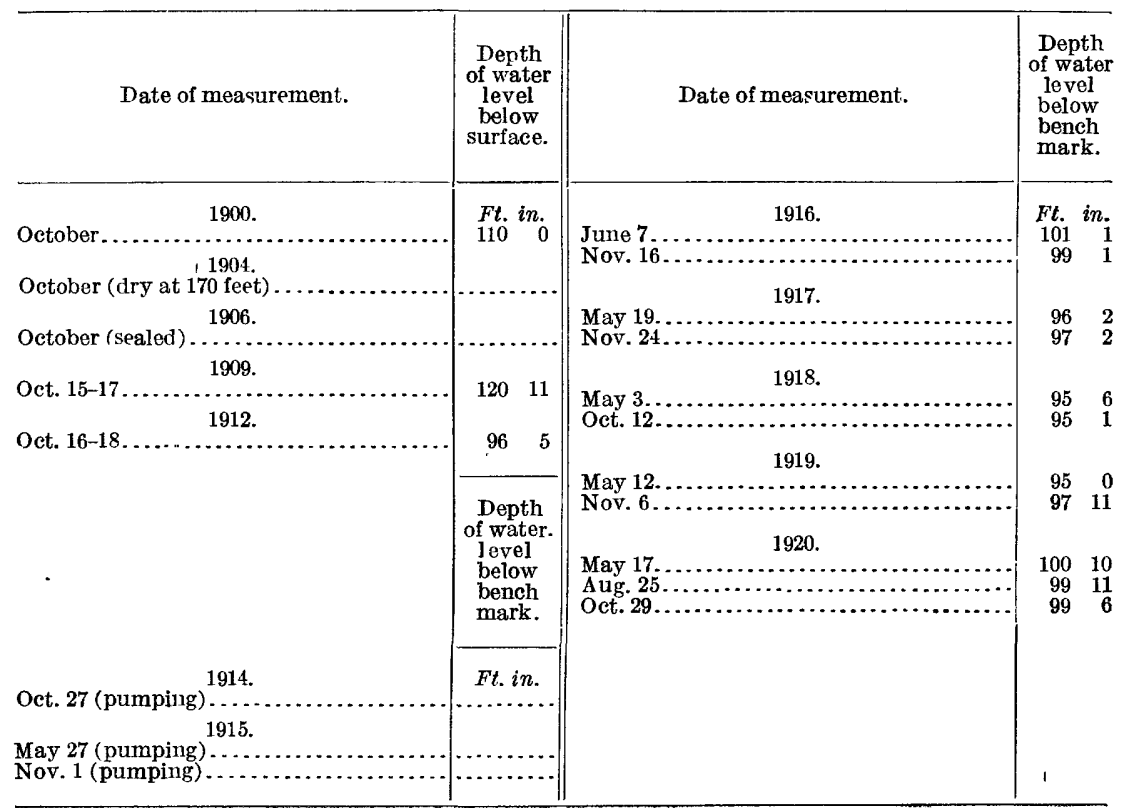


Records of water levels in the valley of southern California-Continued.

127. Mrs. F. Morris, three-fourths mile northwest of Brookside, Redlands quadrangle.

[Bored well, 125 feet deep, 7 inches in diameter; sunk in 1890; method of lift, wind; use, irrigation and domestic. Bench mark: Top of casing, 1 foot 7 inches above surface. Well No. 155, Water-Supply Paper 142, p. 94.]

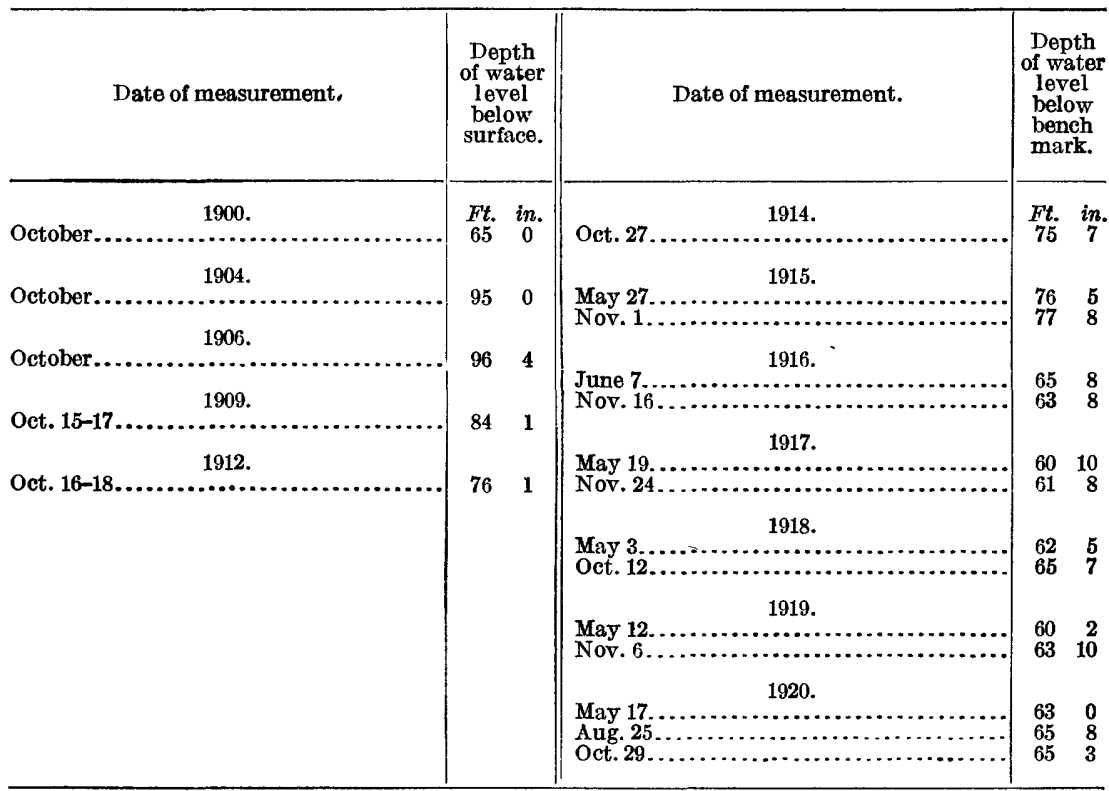

128. Mrs. Parker (formerly owned by E. Vache), one-fourth mile north of Brookside, Redlands quadrangle.

[Bored well, 140 feet deep, 7 inches in diameter; sunk in 1885; method of lift, wind; use, domestic. Bench mark: Top of casing, 2.0 feet above surface. Altitude of bench mark, 1,260.00 feet above sea level. Well No. 48, Water-Supply Paper 142, p. 89.]

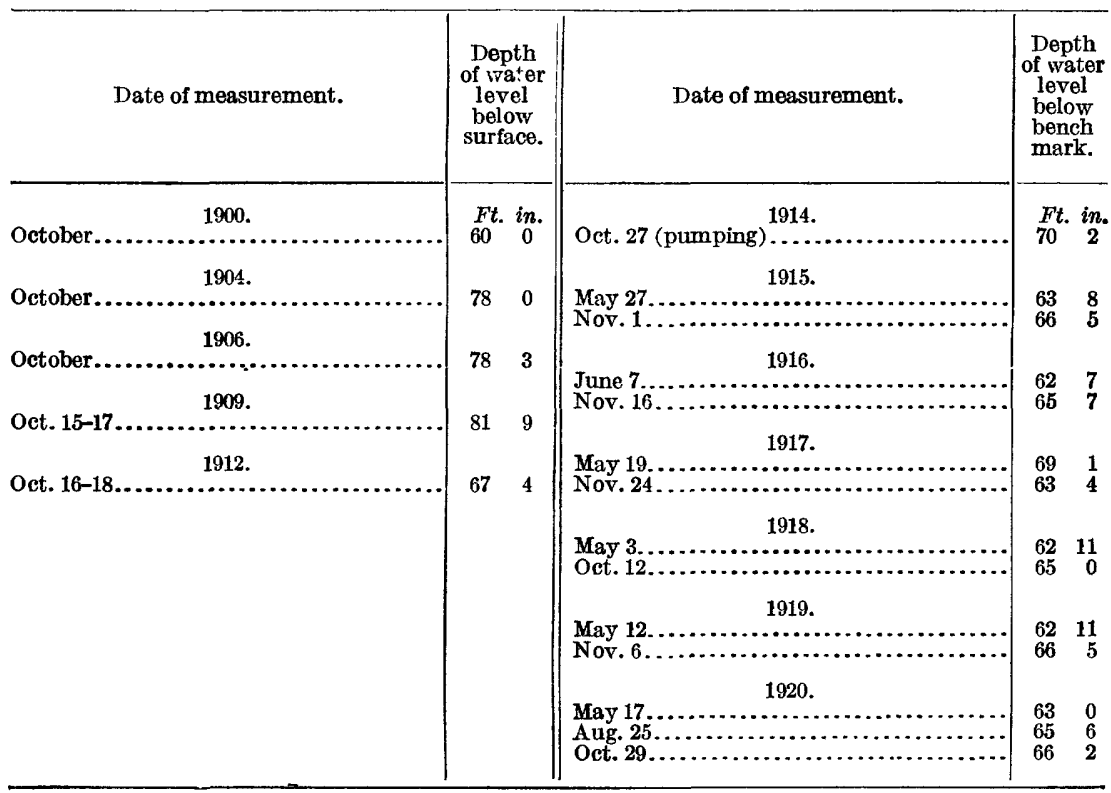


Records of water levels in the valley of southern California-Continued.

129. T. P. Arnold, 1 mile southeast of Bryn Mawr, Redlands quadrangle.

[Dug well, 83 feet deep, 3 by 3 feet in cross section; sunk in 1898; method of lift, wind; use, domestic. Bench mark: Top of casing, 1 foot 10 inches above surface. Well No. 46, Water Supply Paper 142, p. 89.1

\begin{tabular}{|c|c|c|c|}
\hline Date of measurement. & $\begin{array}{c}\text { Depth } \\
\text { of water } \\
\text { level } \\
\text { below } \\
\text { surface. }\end{array}$ & Date of measurement. & $\begin{array}{l}\text { Depth } \\
\text { of water } \\
\text { level } \\
\text { below } \\
\text { bench } \\
\text { mark. } \\
\text {. }\end{array}$ \\
\hline 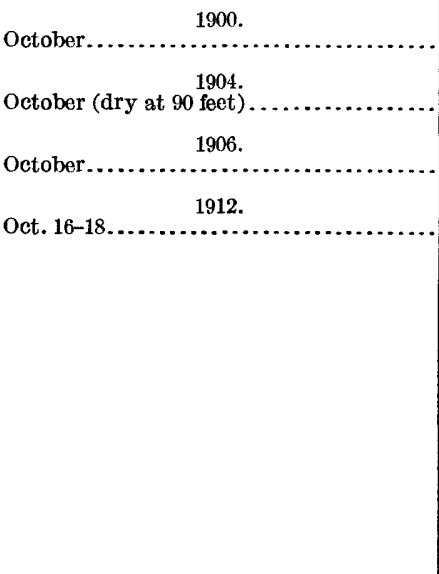 & 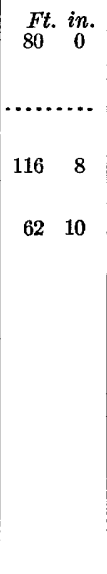 & 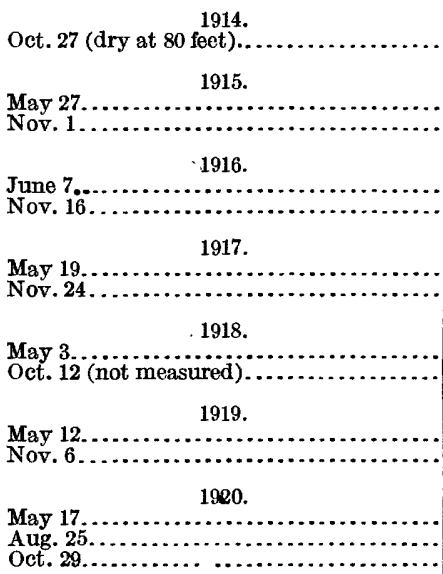 & \begin{tabular}{|rr} 
Ft. & in. \\
& \\
78 & 0 \\
78 & 2 \\
& \\
72 & 10 \\
72 & 4 \\
& \\
76 & 5 \\
70 & 5 \\
& \\
75 & 0 \\
$\cdots$ & \\
& \\
70 & 1 \\
73 & 9 \\
& \\
71 & 11 \\
74 & 1 \\
74 & 8
\end{tabular} \\
\hline
\end{tabular}

130. O. J. Fisk (formerly owned by R. T. Curtis), Bryn Mawr, Redlands quadrangle.

[Bored well, 86 feet deep, 7 inches in diameter; sunk in 1895; method of lift, wind; use, domestic. Bench mark: Top of casing, 1 foot above surface. Altitude of bench mark, 1,188.50 feet above sea level. Well No. 60, Water-Supply Pape: 142, p. 90.]

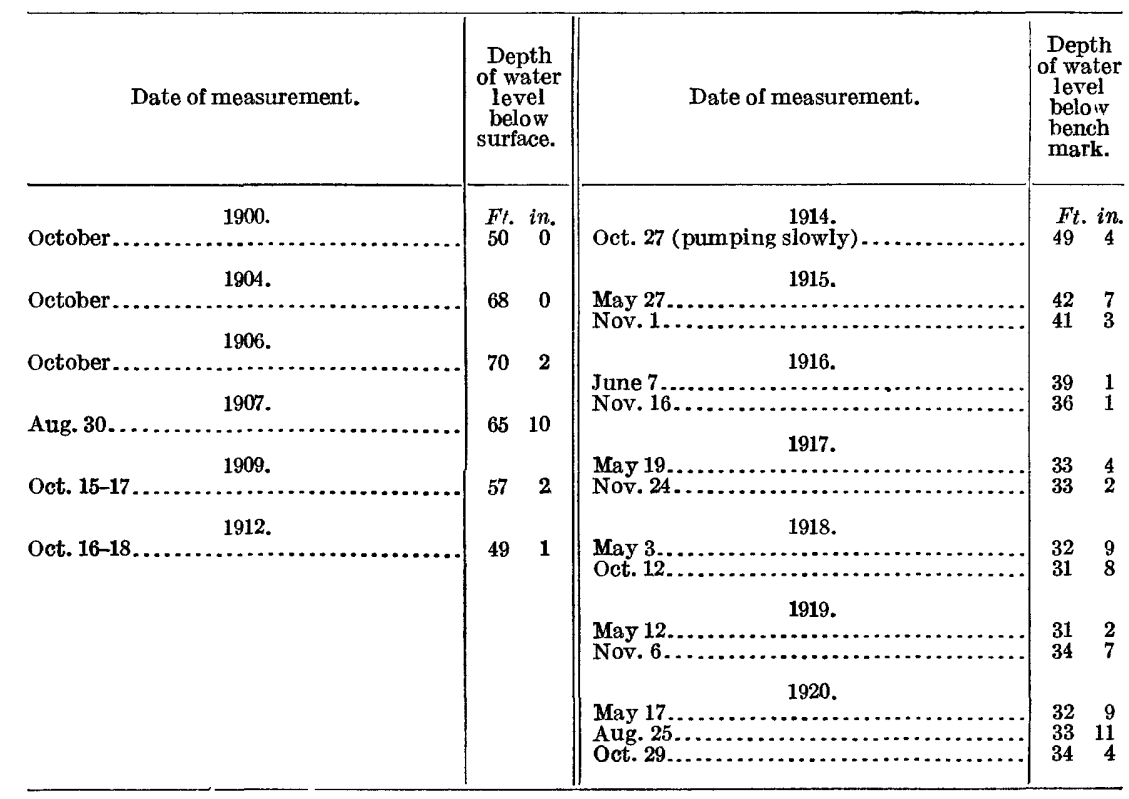


Records of water levels in the valley of southern California-Continued.

131. Frink Bros. (formerly owned by Gansnor \& Renwick), 1 mile southeast of Idlewild, Redlands quadrangle.

[Bored well, 200 feet deep, 7 inches in diameter; sunk in 1898; method of lift, wind; use, domestic and irrigation. Bench mark: Top of casing, 1 foot above surface. 'Well No. 66, Water-Supply Paper 142, p. 90.]

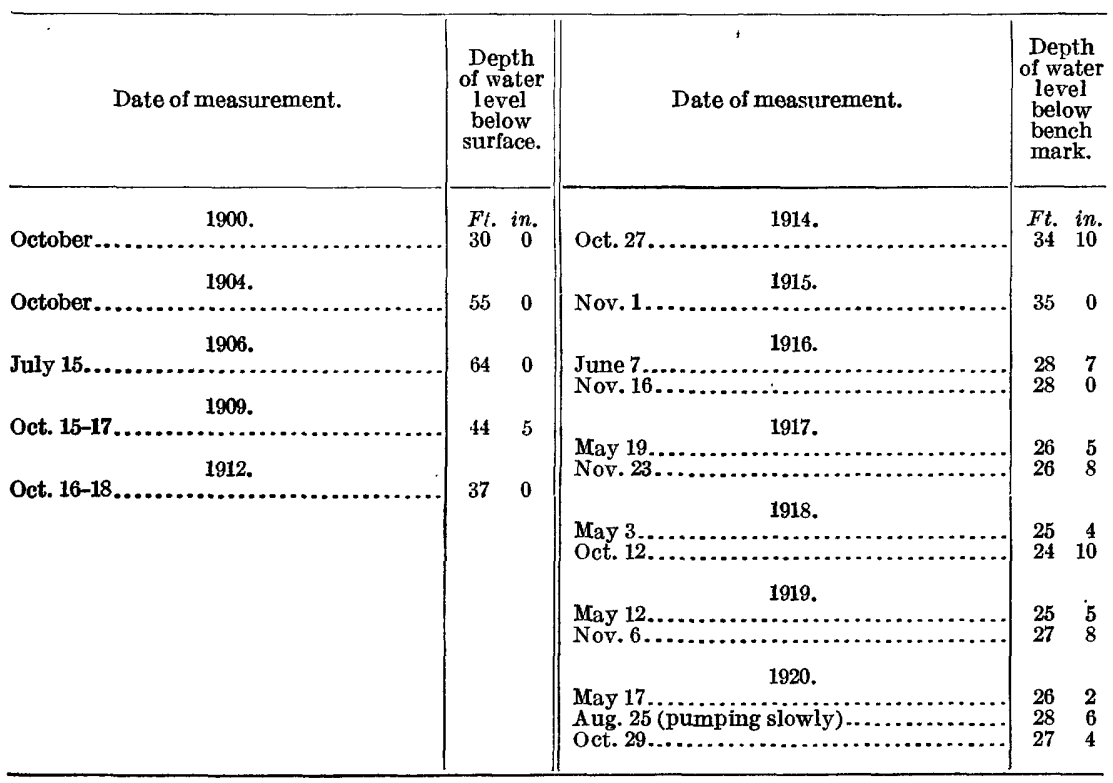

132. F. Buehler (formerly owned by A. Lenanon), 2 miles west of Redlands, Redlands quadrangle.

[Bored well, 130 feet deep, 7 inches in diameter; sunk in 1895; method of lift, windmill; use, domestic. Bench mark: Top of casing, 1 foot above surface. Well No. 84, Water-Supply Paper 142 p.91.]

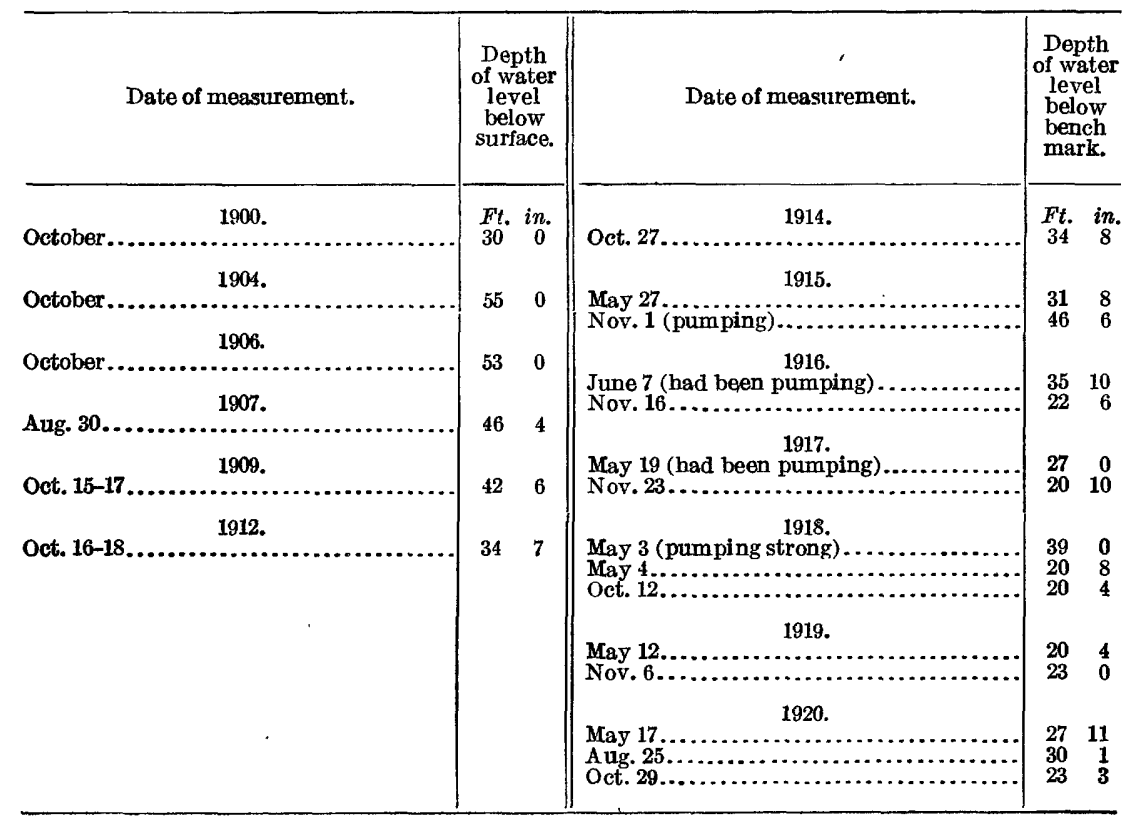




\section{Records of water levels in the valley of southern California-Continued.}

133. James Smith, one-fourth mile east of Drew, Redlands quadrangle.

[Bored well, 90 feet deep, 7 inches in diameter; sunk in 1892; method of lift, windmill; use, domestic. Bench mark: Top of casing, at surface. Well No. 126, Water-Supply Paper 142, p. 93.]

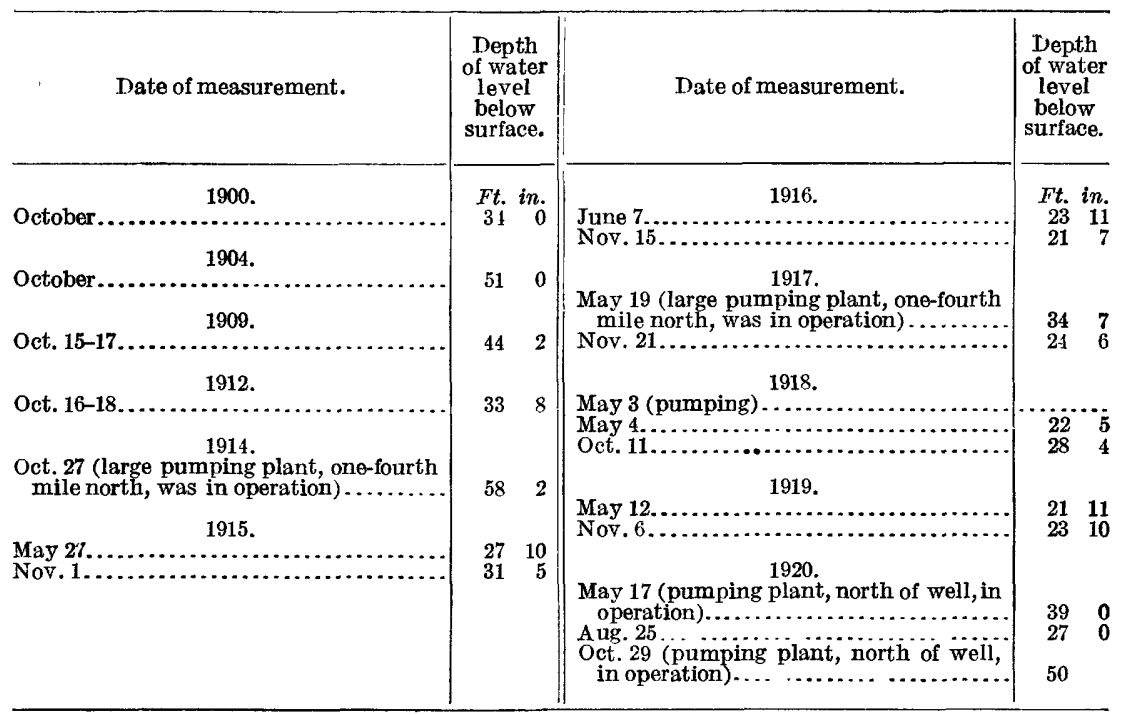

134. H. H. Cole, three-fourths mile east of Idlewild, Redlands quadrangle.

[Bored well, 82 feet deep, 7 inches in diameter; sunk in 1888; method of lift, wind; use, irrigation and domestic. Bench mark: Top of casing, origunally 4 inches above surface. Between May 12 and Nov. 6 , 1919, the casing was raised 1 foot. Beginning with Nov. $6.1919,1$ foot has been subtracted from the measurements to make them comparable with earlier measurements. Well No. 132, Water-Supply Paper 142, p. 93.]

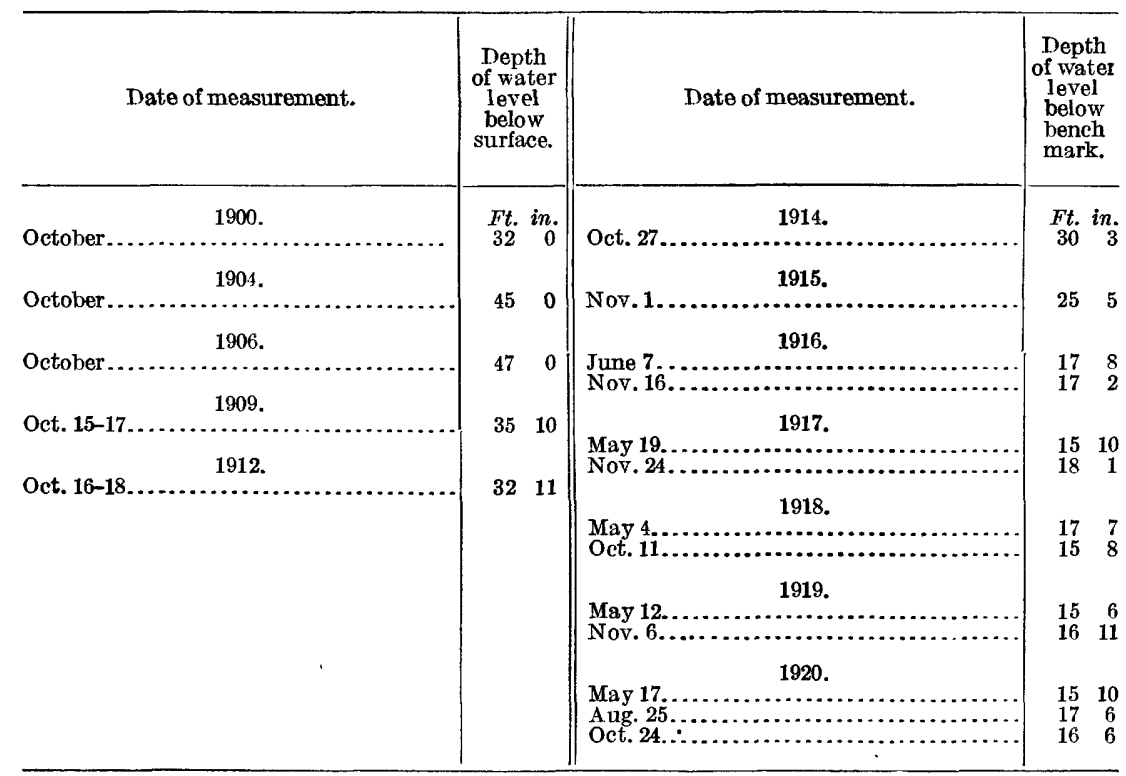


Records of water levels in the valley of southern California-Continued.

135. E. F. Van Leuven, one-fourth mile south of Idlewild, Redlands quadrangle.

[Bored well, 48 feet deep, 7 inches in diameter; sunk in 1890; method of lift, gasoline engine; use, domestic. Bench mark: Top of casing, 1.0 foot above surface. Well No. 145, Water-Supply-Paper 142, p. 93.]

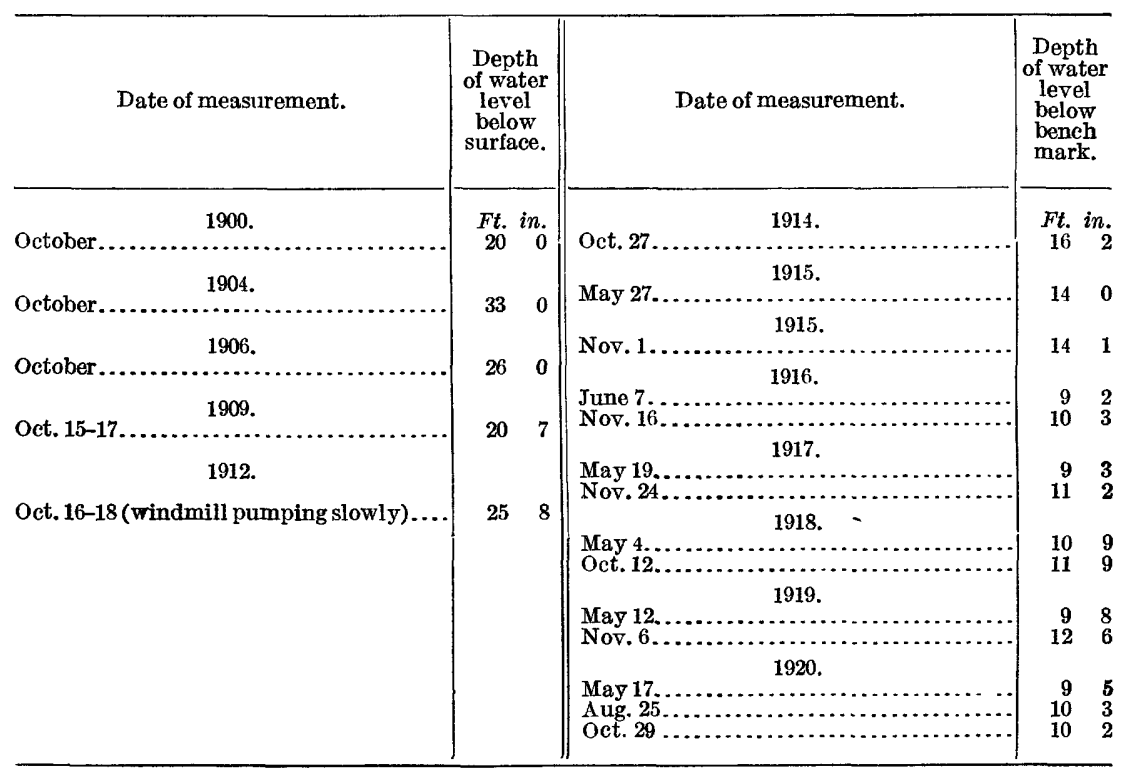

\section{Records of pressure of water in flowing wells in San Bernardino Valley.}

\section{A. Mrs. Murray, 781 West Seventh Street, San Bernardino, San Bernardino quadrangle.}

[Well 158 feet deep, 2 inches in diameter. Overflows part of time. Bench mark: Top of hexagonal, 11-inch nut; 1.4 feet above surface. Altitude of bench mark, $1,081.63$ feet above sea level. Well is fitted with pressure-gage fixtures.]

\begin{tabular}{|c|c|c|c|}
\hline Date of measurement. & $\begin{array}{l}\text { Pounds } \\
\text { per } \\
\text { square } \\
\text { inch. }\end{array}$ & Date of measurement. & $\begin{array}{l}\text { Pounds } \\
\text { per } \\
\text { square } \\
\text { inch. }\end{array}$ \\
\hline 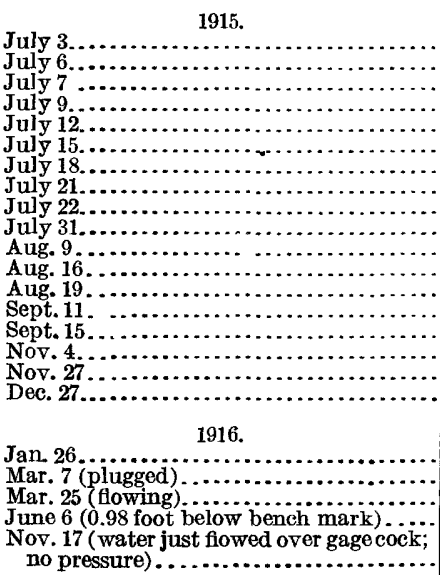 & $\begin{array}{l}5.68 \\
5.67 \\
5.47 \\
5.58 \\
5.67 \\
6.08 \\
6.21 \\
6.55 \\
6.50 \\
6.41 \\
5.80 \\
6.22 \\
7.32 \\
7.98 \\
6.58 \\
6.97 \\
4.48 \\
3.73\end{array}$ & 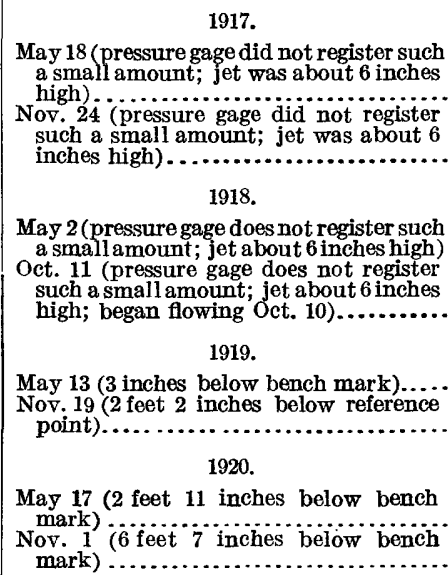 & $\cdots \ldots \ldots$ \\
\hline
\end{tabular}


Records of pressure of water in flowing wells in San Bernardino Valley-Continued.

\section{B. Mrs. Hows, 887 D Street, San Bernardino, San Bernardino quadrangle.}

[Well is 370 feet deep. Altitude of surface, 1,078,47 feet above sea level.]

\begin{tabular}{|c|c|c|c|}
\hline Date of measurement. & $\begin{array}{l}\text { Pounds } \\
\text { per } \\
\text { square } \\
\text { inch. }\end{array}$ & Date of measurement. & $\begin{array}{l}\text { Pounds } \\
\text { per } \\
\text { square } \\
\text { inch. }\end{array}$ \\
\hline 1915 & & 1916-Continued. & \\
\hline July $9 \ldots . .$. & 5.0 & Mar. 25... & \\
\hline 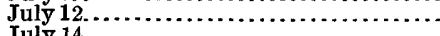 & 5.1 & 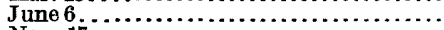 & 5.6 \\
\hline $\begin{array}{r}\text { July } \\
\text { July } 15, \ldots \ldots \ldots \ldots \ldots \ldots \ldots\end{array}$ & $\begin{array}{l}5.1 \\
4.2\end{array}$ & Nov. $17, \ldots \ldots \ldots \ldots \ldots \ldots \ldots \ldots \ldots$ & 8.5 \\
\hline 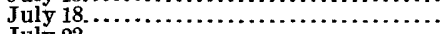 & 3.0 & 1917. & \\
\hline 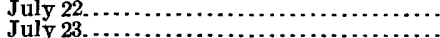 & 2.8 & 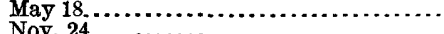 & $\begin{array}{l}8.7 \\
8.0\end{array}$ \\
\hline July $31 . \ldots \ldots \ldots \ldots$ & $\begin{array}{l}0.0 \\
3.7\end{array}$ & Nov. $24 \ldots \ldots \ldots \ldots$ & \\
\hline Aug. 9 Ang. 16 & 3.2 & 1918. & \\
\hline 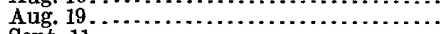 & None. & Oct. $11 . . . . . . . .$. & $\begin{array}{l}8.0 \\
6.5\end{array}$ \\
\hline $\begin{array}{l}\text { Sept. } 11 \ldots \ldots \ldots \ldots \ldots \ldots \ldots \ldots \ldots \\
\text { Sept. } 15 \ldots \ldots \ldots \ldots \ldots \ldots \ldots\end{array}$ & $\begin{array}{r}\text { None. } \\
2.0\end{array}$ & 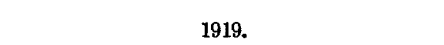 & \\
\hline Nov. $4, \ldots \ldots \ldots$ & 4.6 & May 13 (some leakage past valve stem).. & 6.2 \\
\hline Dec. $27, \ldots \ldots \ldots$ & $\begin{array}{l}4.0 \\
5.2\end{array}$ & 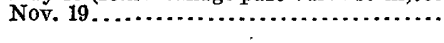 & 5.0 \\
\hline 1916. & & May 15. & 60 \\
\hline Jan. $26, \ldots \ldots \ldots \ldots \ldots \ldots \ldots$ & $\begin{array}{l}5.6 \\
8.6\end{array}$ & Nov. 1. & 3.6 \\
\hline
\end{tabular}

C. Riverside Water Co., Garner tract, fourth easterly well, 150 yards southwest of San Bernardino pumping plant; nearest well to car line, San Bernardino quadrangle.

[Altitude of surface, 1,047.37 feet above sea level.]

\begin{tabular}{|c|c|c|c|}
\hline Date of measurement. & $\begin{array}{l}\text { Pounds } \\
\text { per } \\
\text { square } \\
\text { inch. }\end{array}$ & Date of measurement. & $\begin{array}{l}\text { Pounds } \\
\text { per } \\
\text { square } \\
\text { inch. }\end{array}$ \\
\hline 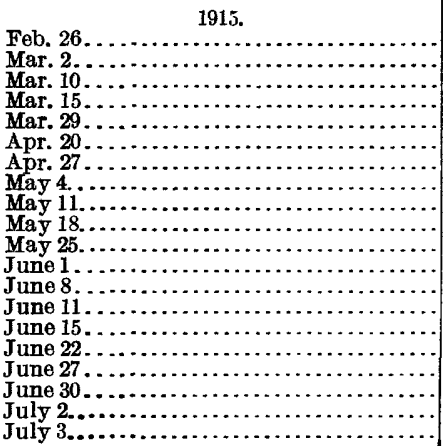 & $\begin{array}{l}26.0 \\
24.0 \\
24.5 \\
23.0 \\
24.5 \\
30.0 \\
31.0 \\
30.0 \\
30.8 \\
30.2 \\
28.7 \\
28.6 \\
28.1 \\
26.0 \\
25.6 \\
26.6 \\
25.6 \\
26.3 \\
26.3 \\
26.7\end{array}$ & 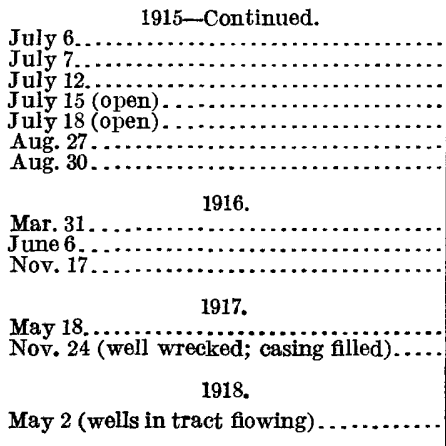 & \begin{tabular}{r} 
\\
22.5 \\
22.3 \\
22.8 \\
$\ldots \ldots \ldots .$. \\
\hdashline$\ldots . . .8$ \\
12.8 \\
18.2
\end{tabular} \\
\hline
\end{tabular}


Records of pressure of water in flowing wells in San Bernardino Valley-Continued.

D. Riverside Water Co., MeCrary tract, 150 feet southwest of barn, second southerly well, San Bernardino quadrangle.

\begin{tabular}{|c|c|c|c|}
\hline Date of measurement. & $\begin{array}{l}\text { Pounds } \\
\text { per } \\
\text { square } \\
\text { inch. }\end{array}$ & Date of measurement. & $\begin{array}{l}\text { Pounds } \\
\text { per } \\
\text { square } \\
\text { inch. }\end{array}$ \\
\hline 1915. & & 1915-Continued. & \\
\hline Feb. $26 . \ldots \ldots \ldots \ldots \ldots \ldots$ & 15.0 & Aug. $18 \ldots \ldots \ldots \ldots \ldots$ & 14.4 \\
\hline Mar. $8 . \ldots \ldots \ldots \ldots \ldots \ldots \ldots \ldots \ldots$ & 15.0 & Aug. $19 \ldots \ldots \ldots \ldots \ldots \ldots$ & 14.2 \\
\hline Mar. $16 . \ldots \ldots \ldots$ & 12.5 & Aug. 20... & $12 . \overline{8}$ \\
\hline 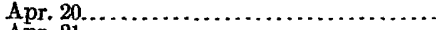 & 18.0 & Aug. $23 \ldots$ & 13.5 \\
\hline 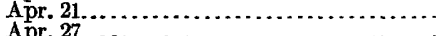 & $20: 0$ & Aug. $30 \ldots \ldots$. & 12.2 \\
\hline 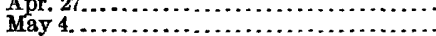 & $\begin{array}{l}20.5 \\
19.6\end{array}$ & $\begin{array}{l}\text { Sept. } 3, \ldots \ldots \\
\text { Sept. } 17, \ldots \ldots\end{array}$ & $\begin{array}{l}15.7 \\
16.0\end{array}$ \\
\hline May $11 \ldots . . . . . . .$. & 20.4 & Oct. $23 \ldots$ & 17. 2 \\
\hline 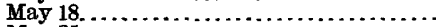 & 20.0 & & \\
\hline May 25........ & 19.2 & 1916. & \\
\hline June $1 \ldots . .$. & 18.5 & June $6 \ldots . . . .$. & 20.1 \\
\hline 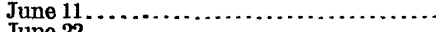 & 18.0 & Nov. $17 \ldots . .$. & 21.6 \\
\hline 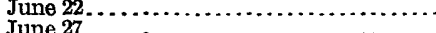 & 18.0 & & \\
\hline 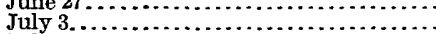 & $\begin{array}{l}17.7 \\
17.4\end{array}$ & May $18 \ldots \ldots \ldots$ & 21.4 \\
\hline July $6 \ldots \ldots \ldots$ & 13.2 & Nov. $24 \ldots \ldots$. & 19.5 \\
\hline $\begin{array}{l}\text { July } \\
\text { July } 12, \ldots \ldots \ldots \ldots\end{array}$ & $\begin{array}{l}17.7 \\
17.9\end{array}$ & 1918. & \\
\hline 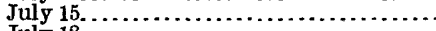 & 16.7 & May 2...... & 18.5 \\
\hline 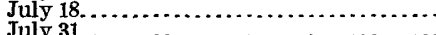 & 16.1 & Oct. $10 \ldots \ldots \ldots \ldots \ldots \ldots \ldots \ldots \ldots \ldots \ldots$ & 13.0 \\
\hline Aug. $4 \ldots$ & 15.2 & 1919. & \\
\hline Aug. $5 . .$. & 15.2 & May 12.......... & 18.0 \\
\hline Aug. $6 . .$. & 16.1 & Nov. $2 \ldots \ldots \ldots \ldots \ldots \ldots \ldots \ldots \ldots$ & 12.5 \\
\hline $\begin{array}{l}\text { Aug. } 7-13( \\
\text { Aug. } 14 . . .\end{array}$ & $14 . \overline{7}$ & 1920. & \\
\hline Aug. 16......... & 15.1 & May $15 \ldots . . . . . . . . . .$. & 18.3 \\
\hline Aug. 17......... & 15.0 & Nov. $27 . . . . . . . . .$. & 17.7 \\
\hline
\end{tabular}

E. Urbita Hot Springs Co., at road corner east of resort, San Bernardino quadrangle.

\begin{tabular}{|c|c|c|c|}
\hline Date of measurement. & $\begin{array}{l}\text { Pounds } \\
\text { per } \\
\text { square } \\
\text { inch. }\end{array}$ & Date of measurement. & $\begin{array}{l}\text { Pounds } \\
\text { per } \\
\text { square } \\
\text { inch. }\end{array}$ \\
\hline 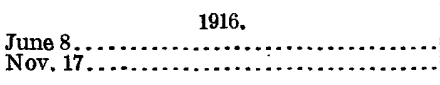 & $\begin{array}{l}5.1 \\
7.8\end{array}$ & 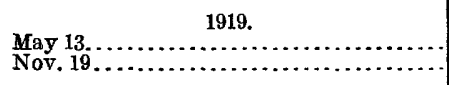 & $\begin{array}{l}5.8 \\
6.3\end{array}$ \\
\hline 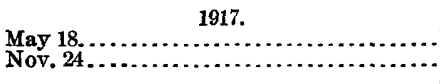 & $\begin{array}{l}5.3 \\
7.0\end{array}$ & $\begin{array}{l}1920, \\
\text { May } 17 \ldots \ldots \ldots \ldots \ldots \ldots \ldots \ldots \ldots \ldots \ldots \ldots \ldots \ldots \ldots \ldots \ldots \ldots \ldots \ldots \ldots \ldots \ldots \ldots \ldots\end{array}$ & $\begin{array}{l}3.9 \\
8.7\end{array}$ \\
\hline 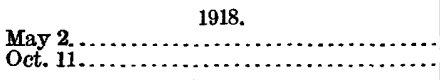 & $\begin{array}{l}5.9 \\
5.9\end{array}$ & $\cdot$ & \\
\hline
\end{tabular}


Records of water levels in wells in San Bernardino Valley that have not been available for measurement since 1913 .

Redlands quadrangle.

\begin{tabular}{|c|c|c|c|c|c|c|c|c|}
\hline \multirow[b]{2}{*}{ No.a } & \multirow[b]{2}{*}{ Owner. } & \multirow[b]{2}{*}{ Location. } & \multicolumn{6}{|c|}{ Depths of water level below surface. } \\
\hline & & & $\begin{array}{l}\text { Octo- } \\
\text { ber, } \\
1900 .\end{array}$ & $\begin{array}{l}\text { Octo- } \\
\text { ber, } \\
1904 .\end{array}$ & $\begin{array}{l}\text { Octo- } \\
\text { ber, } \\
1906 .\end{array}$ & Aug. 30, & $\begin{array}{l}\text { Oct. 15-17, } \\
\text { 1909. }\end{array}$ & $\begin{array}{l}\text { Oct. } \\
16-18, \\
1912 .\end{array}$ \\
\hline 1 & Doctor Meeker . & Sec. 5, T. 1 S., R. 3 W. & $\begin{array}{ll}F t . & \text { in } \\
278 & 0\end{array}$ & Ft. in. & $\begin{array}{l}\text { Ft. in. } \\
\cdots \ldots \ldots .\end{array}$ & Ft. in. & Ft. in. & \\
\hline 14 & W. J. Freneh.. & Sec. 19, T.1 S., R.2 W & 1600 & 1640 & 1390 & $\cdots$ & $126^{2}$ & Inacces- \\
\hline $\begin{array}{r}43 \\
120\end{array}$ & $\begin{array}{l}\text { O. W. Harris....... } \\
\text { M. R. Gay........ }\end{array}$ & $\begin{array}{l}\text { Sec. 34, T. IS., R. } 3 \text { W } \\
\text { Sec. 17, T. } 1 \text { S., R. } 3 \text { W }\end{array}$ & $\begin{array}{rr}200 & 0 \\
50 & 0\end{array}$ & $\begin{array}{rl}b 205 & 0 \\
75 & 0\end{array}$ & $\begin{array}{ll}89 & 1 \\
58 & 0\end{array}$ & 548 & $\begin{array}{rr}218 & 10\end{array}$ & $\begin{array}{l}\text { Do. } \\
\text { (c) }\end{array}$ \\
\hline 125 & H. S. Drew. & Sec. 19, T.1 S., R. 3 W. & $\begin{array}{ll}\mathbf{3 4} & 0\end{array}$ & 300 & & $\ldots+\ldots$ & 360 & Do. \\
\hline 139 & H. R. Scott.... & $\ldots$ do & 120 & $b 200$ & & .......... & 240 & .......... \\
\hline 289 & N. Sutherland..... & Sec. 3 , T. I S., R. 3 W. & 670 & $\begin{array}{ll}93 & 0\end{array}$ & Filled. & ……. & Dostro..... & \\
\hline 386 & $\begin{array}{l}\text { R. F. Cunningham } \\
\text { California State }\end{array}$ & 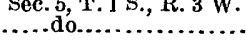 & $\begin{array}{ll}40 & 0 \\
32 & 0\end{array}$ & $\begin{array}{ll}55 & 0 \\
46 & 0\end{array}$ & & Filied. & $\begin{array}{l}\text { Destroyed. } \\
\text { Filled..... }\end{array}$ & Filied. \\
\hline & Hospital. & & & & & 1 & & \\
\hline
\end{tabular}

San Bernardino quadrangle.

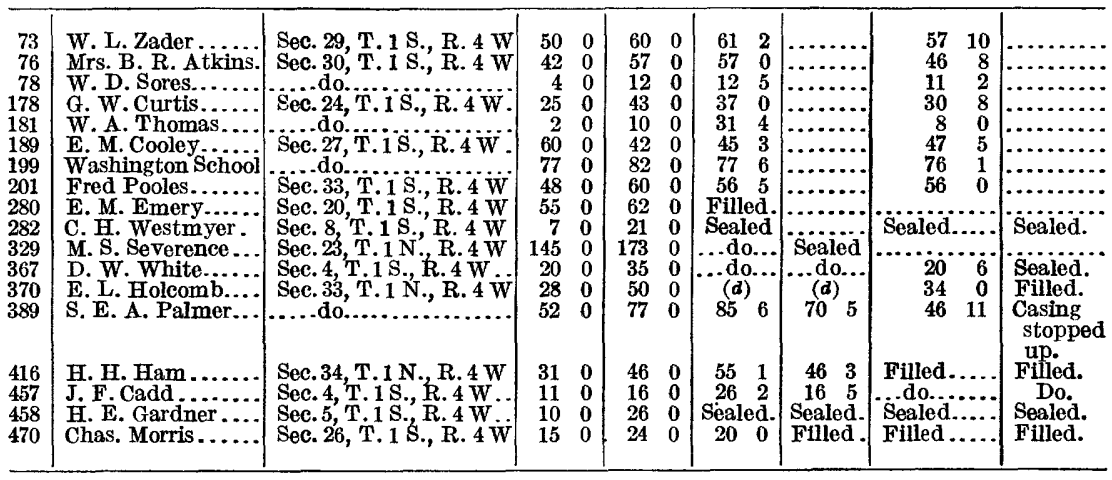

$a$ These are the numbers by which the wells are designated in Water-Supply Paper 142. For further information regarding these wells see that paper.

$b$ Dry at depths given.

$c$ See well No. 118, p. 108.

$d$ Dry at 43 feet. 
Record of water levels in the Williams well, about $4 \frac{1}{2}$ miles east of San Bernardino.a

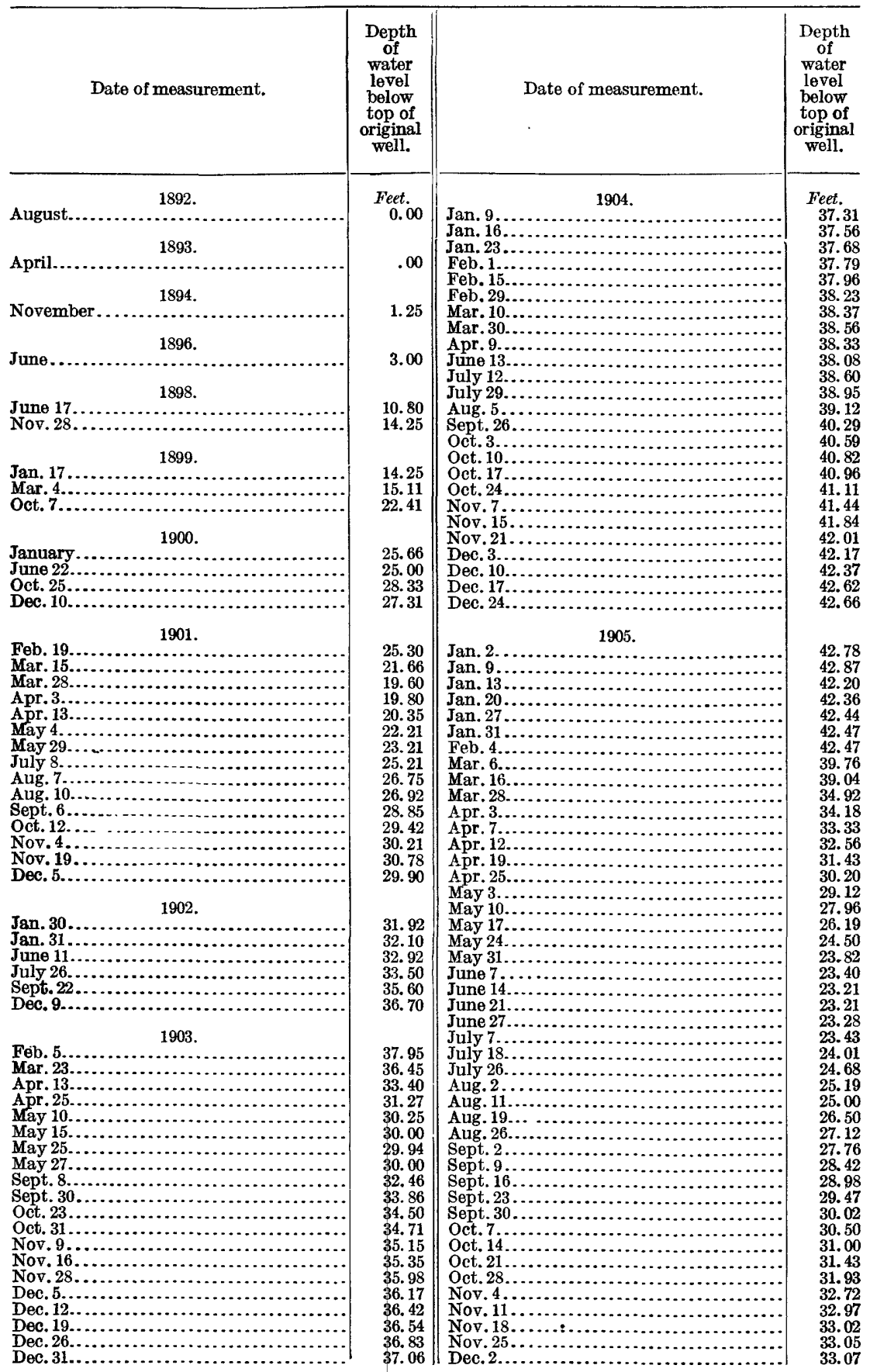


Record of water levels in the Williams well, about $4 \frac{1}{2}$ miles east of San Bernardino-Contd.

\begin{tabular}{|c|c|c|c|}
\hline Date of measurement. & $\begin{array}{c}\text { Depth } \\
\text { of } \\
\text { water } \\
\text { level } \\
\text { below } \\
\text { top of } \\
\text { original } \\
\text { well. }\end{array}$ & Date of $n$ & $\begin{array}{c}\text { Depth } \\
\text { of } \\
\text { water } \\
\text { level } \\
\text { below } \\
\text { top of } \\
\text { original } \\
\text { well. }\end{array}$ \\
\hline & Feet. & & Feet. \\
\hline Dec. $9 \ldots$ & 33.08 & Apr. 13... & 8.20 \\
\hline & 33. 06 & Apr. 20. . & 8.57 \\
\hline Dec. $23 . . .$. & 33.05 & Apr. 27... & 9.12 \\
\hline Dec.30...... & 33.08 & May $4 \ldots . .$. & 9.29 \\
\hline 5 & & May $18 . .$. & $\begin{array}{l}9.34 \\
9.70\end{array}$ \\
\hline Jan. $3 \ldots . .$. & 33.30 & M ay 25... & 9.98 \\
\hline Jan. $13 . .$. & 33.36 & June $1 \ldots . .$. & 10.12 \\
\hline $\operatorname{Jan} .20 \ldots \ldots$ & 33.47 & June $8 \ldots .$. & 10.31 \\
\hline $\operatorname{Jan} .27 \ldots \ldots \ldots$ & 33.50 & June $15 \ldots \ldots$ & $\begin{array}{l}10.48 \\
10.62\end{array}$ \\
\hline $\begin{array}{l}\text { Feb. } 3 \ldots \ldots \\
\text { Feb. } 10 \ldots \ldots\end{array}$ & $\begin{array}{l}33.32 \\
33.16\end{array}$ & $\begin{array}{l}\text { June } 22 \ldots . . \\
\text { June } 29 . \ldots\end{array}$ & $\begin{array}{l}10.62 \\
10.83\end{array}$ \\
\hline Feb. $17 \ldots . .$. & 32.94 & July $6 \ldots$ & 11.08 \\
\hline Feb. 24.... & 32.61 & July 13. . & 11.49 \\
\hline Mar. 3.... & 32.16 & July 20. & 11.82 \\
\hline Mar. 10... & 31.84 & July 27. & 12.16 \\
\hline Mar. 19.... & 29.07 & Aug. 3. & 12.43 \\
\hline Mar. 27. & 24.42 & Aug. 10. & 12.83 \\
\hline Mar. $31 . .$. & 21.37 & Aug. 17. & 13.18 \\
\hline Apr. $7 \ldots \ldots$ & 18.61 & A.ug. 24 . & 13. 56 \\
\hline Apr. 14... & 16.79 & Aug. 31 . & 13.98 \\
\hline Apr.21..... & 15. 66 & Sept.11. & 14.45 \\
\hline Apr.28.... & 14.83 & Sept.16. & 14.73 \\
\hline May $5 . . .$. & 14.18 & Sept. 23 . & 15.06 \\
\hline May $12 . .$. & 13.97 & Sept.30. & 15.42 \\
\hline May $19 . .$. & 13. 98 & Oct. $5 \ldots$ & 15.61 \\
\hline May 26... & 13.87 & Oct. 12 . & 15.88 \\
\hline June 2..... & 13.44 & Oct. $19 \ldots$ & 16.10 \\
\hline June $9 . . .$. & 12.58 & Oct. 26. & 16.16 \\
\hline June $16 . . . . . .$. & 12.28 & Nov. 2 . & 16.07 \\
\hline June $23 . . . . . . .$. & 12. 22 & Nov. 9 & 15. 79 \\
\hline June $30 . .$. & 12.23 & Nov. 16 & 15.48 \\
\hline July $7 . . .$. & 12.47 & Nov. 23 . & 15.21 \\
\hline July $14 . .$. & 12.69 & Nov. 30 . & 15.06 \\
\hline July $21 . .$. & 12.97 & Dec. $7 .$. & 15.09 \\
\hline July $28 \ldots$ & 13.43 & Dec. 14.. & 15.18 \\
\hline Aug. 4 & 13.83 & Dec. 21 . & 15.25 \\
\hline Aug. $11 . . . .$. & 14.27 & Dec. $28 \ldots . .$. & 15.33 \\
\hline Aug. 18....... & 14.83 & & \\
\hline Aug & 15.37 & 1908. & \\
\hline $1 \ldots \ldots$ & 15.98 & $\operatorname{Jan} .4 \ldots$ & 15.36 \\
\hline Sept. $8 \ldots . . . .$. & 16.27 & Jan.11.. & 15.45 \\
\hline $15 \ldots$ & 16.70 & $\operatorname{Jan} .18$ & 15.48 \\
\hline Sep & 17.15 & Jan. 27 . & 15.51 \\
\hline Sept & 17.58 & Feb.1... & 15.28 \\
\hline Oet. & 18.18 & Feb. 8. & 14.60 \\
\hline Oet. & 18.59 & Feb. 15 & 14.01 \\
\hline Oet. 2 & 19.09 & Feb. 22 . & 13.55 \\
\hline Oct. 2 & 19.60 & Feb. 29 & 13.16 \\
\hline Nov.: & 19.92 & Mar. 7. & 12.93 \\
\hline Nov. 10 & 22.46 & Mar.14.. & 12.64 \\
\hline Nov. $17 .$. & 23.12 & Mar.21. & 12.52 \\
\hline & 23.28 & & 12.43 \\
\hline Dec. & 23.41 & & 12.00 \\
\hline Dec. $8 . .$. & 23.44 & Apr.11.. & 11.87 \\
\hline Dec. 15.. & 23.45 & Apr.18. & 11.80 \\
\hline Dec. & 22.78 & & 11.83 \\
\hline Dec. $22 \ldots .$. & 22.50 & May 2.. & 11.90 \\
\hline Dec. $29 . . . . . .$. & 21.28 & May $9 \ldots$ & $\begin{array}{l}\text { 12. } 01 \\
12.00\end{array}$ \\
\hline 1907. & & May $25 . \ldots \ldots \ldots$ & 12.28 \\
\hline $\operatorname{Jan} .8 \ldots$ & 18.31 & May 30......... & 12.48 \\
\hline Jan. 12... & 17.43 & June 1.. & 12.55 \\
\hline Jan.19.. & 14.73 & June 6. & 12.72 \\
\hline $\operatorname{Jan} .26 .$. & 13. 75 & June 13. & 13.69 \\
\hline Feb. $2 .$. & 13.50 & June20. & 14.83 \\
\hline Feb. $9 \ldots$ & 13.06 & June 27. & 15.30 \\
\hline Feb. $16 .$. & 12.66 & & 15.76 \\
\hline Feb. $23 .$. & 12.33 & July $6 .$. & 15.84 \\
\hline Mar. 2... & 11.47 & July 11. & 16.11 \\
\hline Mar. 9.... & 10.97 & & 16.17 \\
\hline Mar. 18........... & 10.08 & July 18. & 16.36 \\
\hline Mar. 23....... & 9.73 & July 20. & 16.37 \\
\hline 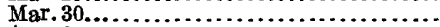 & 8.81 & July 25. . & 16.47 \\
\hline (1) & 8.10 & Aug. 1.. & 16. 78 \\
\hline
\end{tabular}


Record of water levels in the Williams well, about $4 \frac{1}{2}$ miles east of San Bernardino-Contd.

\begin{tabular}{|c|c|c|c|}
\hline Date of measurement. & $\begin{array}{c}\text { Depth } \\
\text { of } \\
\text { water } \\
\text { level } \\
\text { below } \\
\text { top of } \\
\text { original } \\
\text { well. }\end{array}$ & Date of measurement. & $\begin{array}{c}\text { Depth } \\
\text { of } \\
\text { water } \\
\text { level } \\
\text { below } \\
\text { top of } \\
\text { original } \\
\text { well. }\end{array}$ \\
\hline 1908-Continued. & Feet. & $T=0$ & Feet. \\
\hline Aug. $8 .$. & 17.14 & Jan. $8 \ldots .$. & 8.00 \\
\hline $\begin{array}{l}\text { Aug. 15.. } \\
\text { Aug. 17.. }\end{array}$ & $\begin{array}{l}17.31 \\
17.35\end{array}$ & Jan. 15... & 7.13 \\
\hline Aug. $22 \ldots$ & 17.84 & Jan. $29 \ldots$ & $\begin{array}{l}6.67 \\
6.33\end{array}$ \\
\hline $\begin{array}{l}\text { Aug. } 29 \ldots \\
\text { Sept.5.... }\end{array}$ & $\begin{array}{l}18.46 \\
18.74\end{array}$ & Feb. $5 \ldots$ & $\begin{array}{l}6.13 \\
6.01\end{array}$ \\
\hline Sept. 12. & 18.81 & Feb.14.... & 5.99 \\
\hline $\begin{array}{l}\text { Sept. } 19 \ldots \\
\text { Sept. } 26 \ldots\end{array}$ & $\begin{array}{l}18.94 \\
19.05\end{array}$ & Feb. $19 \ldots$ & $\begin{array}{l}5.98 \\
6.02\end{array}$ \\
\hline Oct. $3 . . .$. & 19.17 & Mar. $5 \ldots . .$. & $\begin{array}{l}0.02 \\
6.10\end{array}$ \\
\hline Oct. $10 \ldots . .$. & $\begin{array}{l}19.33 \\
19.84\end{array}$ & Mar. $12 \ldots$ & 6. 27 \\
\hline Oct. $24 \ldots \ldots$ & 19.98 & $\begin{array}{l}\text { Mar.19.... } \\
\text { Mar. 26.... }\end{array}$ & $\begin{array}{l}6.32 \\
6.39\end{array}$ \\
\hline $\begin{array}{l}\text { Oct. } 31 \ldots . . \\
\text { Nov. } 7 \ldots\end{array}$ & $\begin{array}{l}20.17 \\
20.37\end{array}$ & Apr. $2 \ldots \ldots$. & 6.38 \\
\hline Nov. $14 . . . .$. & 20.48 & Apr. $9_{1} \ldots \ldots$ & 6.31 \\
\hline $\begin{array}{l}\text { Nov. } 24 \ldots \ldots \\
\text { Nov. } 28 . . . . .\end{array}$ & $\begin{array}{l}20.81 \\
20.83\end{array}$ & $\begin{array}{l}\text { Apr. } 16 \ldots \ldots \ldots \ldots \\
\text { Apr. } 23 \ldots \ldots \ldots \ldots\end{array}$ & $\begin{array}{l}6.25 \\
6.23\end{array}$ \\
\hline Dec. $8 \ldots . . .$. & $\begin{array}{l}20.88 \\
20.93\end{array}$ & Apr. $30 \ldots \ldots \ldots$ & 6.90 \\
\hline Dec.19.... & 20.90 & May $14 . . . . . . .$. & $\begin{array}{l}7.40 \\
7.78\end{array}$ \\
\hline Dec. 26.... & 20.90 & May $21 . . . \ldots \ldots \ldots \ldots \ldots$ & 8. 04 \\
\hline $\operatorname{Tan} .2 \ldots$. & 20.93 & 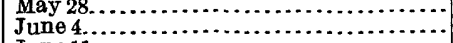 & 8.75 \\
\hline $\operatorname{Jan} .9 . . .$. & 20.40 & June $11 . . . . . . .$. & 9.25 \\
\hline $\operatorname{Jan} .16 \ldots . .$. & 19.15 & June $18 \ldots . .$. & 9.58 \\
\hline $\operatorname{Jan} .23 \ldots$ & 17.65 & $\begin{array}{l}\text { June } 25 \ldots . . . \\
\text { July } 7 \ldots . . .\end{array}$ & $\begin{array}{r}9.96 \\
10.95\end{array}$ \\
\hline $\begin{array}{l}\text { Jan.30. } \\
\text { Feb.6.. }\end{array}$ & $\begin{array}{l}15.88 \\
14.86\end{array}$ & $\begin{array}{l}\text { July } 7 \ldots \ldots \\
\text { July } 9 \ldots \ldots\end{array}$ & $\begin{array}{l}10.95 \\
11.15\end{array}$ \\
\hline Feb.13.... & 12.96 & July $16 . . .$. & 11.76 \\
\hline Feb.20...... & 11.55 & July $23 \ldots \ldots \ldots$ & 12.01 \\
\hline Feb.27..... & 10.57 & July $30 \ldots \ldots \ldots$ & $\begin{array}{l}12.30 \\
12.52\end{array}$ \\
\hline Mar.7..... & $\begin{array}{r}10.12 \\
9.92\end{array}$ & $\begin{array}{l}\text { Aug. } 6 \ldots \ldots . \\
\text { Aug. } 13 . \ldots .\end{array}$ & $\begin{array}{l}12.52 \\
12.86\end{array}$ \\
\hline Mar. 20... & 9.79 & Aug. $20 \ldots$ & 13.22 \\
\hline Mar. 27........ & 9.04 & Aug. $27 \ldots .$. & 13. 56 \\
\hline Apr. $3 \ldots \ldots \ldots$ & 8.37 & Sept. $3 \ldots \ldots \ldots$ & 13.84 \\
\hline 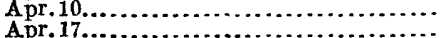 & $\begin{array}{l}7.93 \\
7.94\end{array}$ & $\begin{array}{l}\text { Sept. 10......... } \\
\text { Sept. 17....... }\end{array}$ & $\begin{array}{l}14.14 \\
14.44\end{array}$ \\
\hline Apr.24.... & 7.72 & Sept.24..... & 14. 71 \\
\hline & 7.58 & Oct. $1 \ldots \ldots$ & 14.84 \\
\hline May $8 . .$. & 7.50 & Oct. $8 . .$. & 15.11 \\
\hline May $15 . .$. & 7.50 & Oct.15.... & 15.41 \\
\hline May $22 . . .$. & 7.51 & Oct. $22 \ldots \ldots \ldots$ & 15.47 \\
\hline 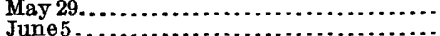 & $\begin{array}{l}7.54 \\
7.83\end{array}$ & Oct. $29 \ldots \ldots \ldots$ & $\begin{array}{l}15.52 \\
15.62\end{array}$ \\
\hline June $12, \ldots \ldots \ldots \ldots$ & 8.37 & Nov. $5 \ldots \ldots \ldots$ & $\begin{array}{l}15.62 \\
15.64\end{array}$ \\
\hline June 19.. & 9.07 & Nov. $19 \ldots$. & 15.68 \\
\hline & 9.50 & Nov.26........ & 15.68 \\
\hline July $3 .$. & 10.02 & Dec. $3 \ldots \ldots \ldots$ & 15.70 \\
\hline July 10 . - & 10.57 & Dec. 10.... & 15.70 \\
\hline July 17. & 11.08 & Dec. $17 \ldots \ldots$. & 15. 70 \\
\hline July $24 .$. & 11.62 & Dec. $24 \ldots . . .$. & 15. 52 \\
\hline July $31 .$. & 12.09 & Dec. $31 . . .$. & 15.43 \\
\hline $\begin{array}{l}\text { Aug. } 7:- \\
\text { Aug. } 14 .\end{array}$ & $\begin{array}{l}12.54 \\
12.99\end{array}$ & 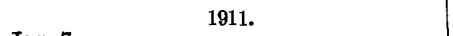 & \\
\hline Aug. 21.... & 13.42 & Jan. $7 \ldots . .$. & 15.49 \\
\hline Aug. 28..... & 13.87 & Jan.14.... & 15.06 \\
\hline Sept. $4 \ldots \ldots$ & 14.10 & $\begin{array}{l}\text { Jan. } 21 \ldots \\
\text { Jan. } 30 . . .\end{array}$ & 12.70 \\
\hline Sept. $18 . .$. & $\begin{array}{l}14.37 \\
14.69\end{array}$ & Feb. $4 \ldots \ldots \ldots$ & 9.79 \\
\hline Sept. $25 . .$. & 15. 33 & Feb. 11........... & 9.79 \\
\hline Oct. $2 \ldots \ldots \ldots \ldots$ & 15.42 & Feb. 18......... & $\begin{array}{l}7.61 \\
7.57\end{array}$ \\
\hline $\begin{array}{l}\text { Oct. } 9 \ldots \ldots \ldots \ldots . . \\
\text { Oct. } 16 \ldots \ldots \ldots \ldots\end{array}$ & 15. 72 & $\begin{array}{l}\text { Feb. 25.... } \\
\text { Mar. } 4 \ldots . .\end{array}$ & 6.54 \\
\hline $\begin{array}{l}\text { Oct. } 16 \ldots \ldots . \\
\text { Oet. } 23 . . . . .\end{array}$ & $\begin{array}{l}15.85 \\
16.00\end{array}$ & 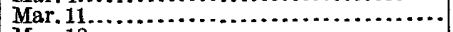 & 5.93 \\
\hline 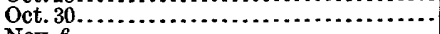 & 16.14 & Mar $18 . \ldots \ldots \ldots \ldots \ldots \ldots$ & 5.37 \\
\hline 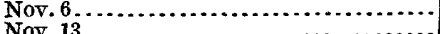 & 16. 35 & Mar. $25 \ldots \ldots \ldots \ldots \ldots \ldots \ldots \ldots$ & $\begin{array}{l}5.08 \\
4.91\end{array}$ \\
\hline 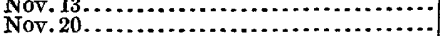 & $\begin{array}{l}16.49 \\
16.28\end{array}$ & Apr. 8.10 & 4.77 \\
\hline Nov $27 \ldots \ldots \ldots \ldots$ & 15.67 & Apr. $15, \ldots \ldots \ldots$ & 4.75 \\
\hline 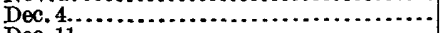 & 15. 34 & Apr. $22 \ldots \ldots \ldots$ & 4.68 \\
\hline 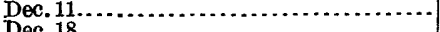 & 14. 33 & Apr. $30 \ldots \ldots \ldots$ & $\begin{array}{l}4.60 \\
4.61\end{array}$ \\
\hline $\begin{array}{l}\text { Dec. } 18 \ldots \ldots \ldots \ldots \ldots \ldots \ldots \\
\text { Dec, } 25, \ldots \ldots \ldots \ldots \ldots\end{array}$ & $\begin{array}{l}10.61 \\
10.36\end{array}$ & 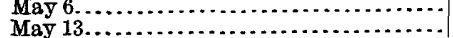 & $\begin{array}{l}4.01 \\
4.78\end{array}$ \\
\hline & 10.36 & 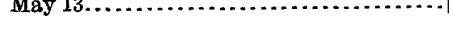 & \\
\hline
\end{tabular}




\section{Record of water levels in the Williams well, about $4 \frac{1}{2}$ miles east of San Bernardino-Contd.}

\begin{tabular}{|c|c|c|c|}
\hline Date of measurement. & $\begin{array}{c}\text { Depth } \\
\text { of } \\
\text { water } \\
\text { level } \\
\text { below } \\
\text { top of } \\
\text { original } \\
\text { well. }\end{array}$ & Date of measurement. & $\begin{array}{c}\text { Depth } \\
\text { of } \\
\text { water } \\
\text { level } \\
\text { below } \\
\text { top of } \\
\text { original } \\
\text { well. }\end{array}$ \\
\hline & Feet. & 191 & Feet. \\
\hline May 20... & 5. 00 & Oct. $19 .$. & 13.97 \\
\hline Lay $27 \ldots$ & 5. 16 & Oct. $26 .$. & 14.02 \\
\hline June $3 \ldots \ldots$ & 5.32 & Nov. $2 \ldots$ & 14.20 \\
\hline $\begin{array}{l}\text { June } 10 \\
\text { June } 17 \ldots \ldots \ldots \ldots \ldots \ldots \ldots\end{array}$ & $\begin{array}{l}5.70 \\
6.10\end{array}$ & $\begin{array}{l}\text { Nov. } 9 \ldots \\
\text { Nov. } 16 \ldots\end{array}$ & $\begin{array}{l}14.23 \\
14.26\end{array}$ \\
\hline June $24 . . . . . . .$. & 6.44 & Nov. 23... & 14. 34 \\
\hline aly $1 . .$. & 6.76 & Nov. $30 .$. & 14.43 \\
\hline July $8 . \ldots$. & 7.13 & Dec. $7 \ldots . .$. & 14. 53 \\
\hline July $15 \ldots \ldots$ & $\begin{array}{l}7.31 \\
7.49\end{array}$ & $\begin{array}{l}\text { Dec. } 14 \ldots \ldots . \\
\text { Dec. } 21 . . . .\end{array}$ & $\begin{array}{l}14.62 \\
14.68\end{array}$ \\
\hline July $29 . \ldots$. & $\begin{array}{l}7.69 \\
7.69\end{array}$ & Dec. $28 . . .$. & 14.75 \\
\hline Aug. $5 \ldots$ & 7.87 & 1913. & \\
\hline Aug. 19... & $\begin{array}{l}8.00 \\
8.20\end{array}$ & $\operatorname{Jan} .4 \ldots . . .$. & 14.80 \\
\hline Aug. 26...... & 8.39 & Jan. $11 \ldots \ldots$. & 14. 85 \\
\hline $\begin{array}{l}\text { Sept. } 2 \ldots \ldots \ldots . . \\
\text { Sept. } 9 \ldots \ldots \ldots . .\end{array}$ & $\begin{array}{l}8.58 \\
8.82\end{array}$ & $\begin{array}{l}\text { Jan. } 18 \ldots \ldots . \\
\text { Jan. } 25 . . . . .\end{array}$ & $\begin{array}{l}14.88 \\
14.88\end{array}$ \\
\hline Sept. $16 \ldots$ & $\begin{array}{l}8.82 \\
9.08\end{array}$ & Feb. 1......... & 14.82 \\
\hline $23 \ldots$ & 9.31 & Feb. $8 \ldots$ & 14. 80 \\
\hline $30 \ldots$ & 9.50 & Feb. 15... & 14.71 \\
\hline & 9.67 & Feb. 22. & 14.55 \\
\hline $14 \ldots$ & 9.85 & Mar. 1.... & 14. 22 \\
\hline Oct. $21 \ldots$ & 9.99 & Mar. 8... & 14.03 \\
\hline Oct. $28 \ldots$. & 10.16 & Mar. 15. & 13.70 \\
\hline Nov. $4 \ldots .$. & 10.27 & Mar. 22.. & 13.39 \\
\hline No & 10.36 & Mar. 29.. & 13.16 \\
\hline Nov & 10.46 & Apr. $5 \ldots$ & 13.07 \\
\hline Nov. & 10.53 & Apr. 12. & 13.06 \\
\hline Dec & 10.67 & 19 & 13.08 \\
\hline Dec. $9 . .$. & 10.76 & Apr. 26. & 13.19 \\
\hline Dec & 10.83 & May $3 . .$. & 13. 41 \\
\hline & 10.9 & 10. & 14.16 \\
\hline Dec. $30 . . .$. & 10.99 & May 17.. & 15.25 \\
\hline & & May $24 .$. & 15.89 \\
\hline 12 & & May 31. & 15.93 \\
\hline $\operatorname{Jan} .6 . . .$. & 11.08 & Jun & 16. \\
\hline & 11. 11 & June $14 .$. & 16.13 \\
\hline Jan. $20 \ldots$ & 11.15 & June $21 . .$. & 16.20 \\
\hline $27 \ldots$ & 11. 21 & June 28 . . & 16.27 \\
\hline & 11. 27 & July $5 . .$. & 16.45 \\
\hline $10 \ldots$ & 11. 30 & July $12 \ldots$ & 16.65 \\
\hline Feb.17... & 11. 35 & July $19 .$. & 17. \\
\hline & 11. 40 & July $26 \ldots$ & 17.64 \\
\hline $2 \ldots$ & 11. 49 & Aug. $2 \ldots$ & 17.80 \\
\hline $\mathrm{Ma}$ & 11. 56 & Aug. 9. & 18.00 \\
\hline & 11.55 & Aug. 16.... & \\
\hline $\mathrm{Ma}$ & 11. 42 & Aug. $23 . . .$. & 18.47 \\
\hline & 10.51 & Aug. 30 . & 18.64 \\
\hline & 10.04 & & \\
\hline Ap & 9.6 & Sept. 13. & 18.90 \\
\hline & 9.10 & 20. & 19.04 \\
\hline Apr. 27...... & 8.67 & Sept. 27. & 19.19 \\
\hline & 8.26 & Oct. $4 \ldots$ & 19.42 \\
\hline & 8. 10 & Oct. $11 \ldots . .$. & 19.60 \\
\hline $18 .$. & 7.87 & Oct. $18 \ldots \ldots$ & 19.76 \\
\hline & 7.84 & Oet. 25. & 19.90 \\
\hline June $1 \ldots . .$. & 7.83 & Nov. 1. & 20.05 \\
\hline & 7.9 & Nov. 8. & 20.51 \\
\hline & 8.04 & Nov. 15. & 20.56 \\
\hline le $22 . \ldots$. & 8.21 & Nov. 22 . & 20.57 \\
\hline e $29 \ldots \ldots$ & 8. 37 & Nov. 29 . & 20.47 \\
\hline & 8. 80 & Dec. $6 \ldots$ & 20.32 \\
\hline $\mathrm{Ju}$ & 9.10 & Dec. $13 .$. & 20.03 \\
\hline & 9.23 & Dec. $20 \ldots \ldots \ldots \ldots \ldots \ldots$ & 19.93 \\
\hline (n.................. & $9 . \overline{79}$ & Dec. $27 \ldots \ldots \ldots \ldots \ldots \ldots$ & 19.86 \\
\hline$A_{1}$ & 10.21 & & \\
\hline Aug. 10.. & 10.68 & 1914. & \\
\hline $17 \ldots \ldots$ & 11.26 & Jan. $3 .$. & 19.56 \\
\hline 4 & 12. 05 & Jan. $10 .$. & 19.33 \\
\hline Sep & 12.87 & Jan. $17 .$. & 19.01 \\
\hline t. $14 \ldots \ldots \ldots$ & 13. 05 & & 18.17 \\
\hline Sept. 21 & 13.29 & Jan. $31 \ldots$ & 14.83 \\
\hline Sept. $28 \ldots \ldots \ldots \ldots$ & 13.52 & Feb.7... & 14.04 \\
\hline Oet. $5 \ldots \ldots \ldots \ldots \ldots$ & 13.88 & Feb. 14........ & 14.06 \\
\hline Oct. 1 & 13.90 & Feb. $21 . . . \ldots$ & 11.06 \\
\hline
\end{tabular}


Record of water levels in the Williams well, about $4 \frac{1}{2}$ miles east of San Bernardino-Contd.

\begin{tabular}{|c|c|c|c|}
\hline Date of measurement. & $\begin{array}{c}\text { Depth } \\
\text { of } \\
\text { water } \\
\text { level } \\
\text { below } \\
\text { top of } \\
\text { original } \\
\text { well. }\end{array}$ & Date of measurement. & $\begin{array}{c}\text { Depth } \\
\text { of } \\
\text { water } \\
\text { level } \\
\text { below } \\
\text { top of } \\
\text { original } \\
\text { well. }\end{array}$ \\
\hline 1914-Continued. & Feet. & 1915-Continued. & Feet. \\
\hline$\ldots \ldots \ldots \ldots \ldots \ldots$ & 8.53 & $\ldots \ldots \ldots \ldots \ldots \ldots \ldots \ldots \ldots \ldots \ldots \ldots$ & 4.85 \\
\hline 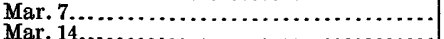 & 7.60 & 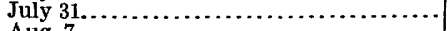 & 5.24 \\
\hline $\begin{array}{l}\text { Mar. } 14 \\
\text { Mar. } 21, \ldots \ldots\end{array}$ & $\begin{array}{l}7.38 \\
7.30\end{array}$ & $\begin{array}{l}\text { Aug. } 7{ }_{1} \\
\text { Aug. } 14, \ldots 1\end{array}$ & $\begin{array}{l}5.51 \\
5.85\end{array}$ \\
\hline 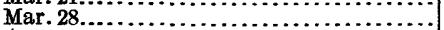 & 7.25 & Aug. $21, \ldots \ldots \ldots$ & 6.16 \\
\hline Apr. 4 . & 7.06 & (1) & 6.27 \\
\hline (2. & 6.87 & (1) & 6.69 \\
\hline Apr. $18 \ldots .$. & 6.83 & 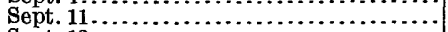 & 7.01 \\
\hline Apr. 25. & 6.77 & Sept. 18........... & 7.30 \\
\hline 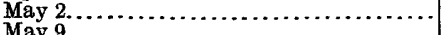 & 6.45 & Sept. 25........ & 7.53 \\
\hline 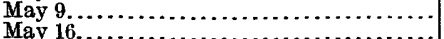 & 6.01 & 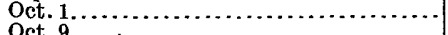 & 7.84 \\
\hline $\begin{array}{l}\text { May } 16, \ldots \ldots \\
\text { May }\end{array}$ & $\begin{array}{l}5.75 \\
5.57\end{array}$ & 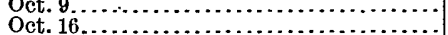 & $\begin{array}{l}8.14 \\
8.37\end{array}$ \\
\hline 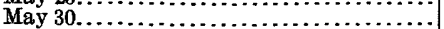 & 5.53 & Oct. $23 \ldots \ldots \ldots \ldots$ & 8.54 \\
\hline June $6 \ldots \ldots \ldots$ & 5.47 & Oct. $30 \ldots \ldots . . . .$. & 8. 69 \\
\hline June $13, \ldots \ldots \ldots$ & 5.43 & Nov. $6 . . . \ldots \ldots \ldots \ldots$ & 8.83 \\
\hline June $20 . \ldots \ldots \ldots$ & 5.61 & 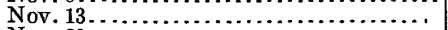 & 8.84 \\
\hline June $27 \ldots \ldots \ldots \ldots \ldots \ldots \ldots \ldots$ & 5.95 & 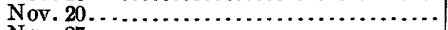 & 8. 62 \\
\hline July $4 \ldots \ldots \ldots \ldots \ldots \ldots \ldots \ldots \ldots \ldots \ldots \ldots \ldots \ldots$ & 6.38 & 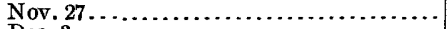 & 8.55 \\
\hline July $11 \ldots \ldots \ldots \ldots \ldots \ldots \ldots \ldots \ldots$ & 6.81 & Dec. $3 \ldots . . . .$. & 8.52 \\
\hline$\ldots \ldots \ldots$ & 7.20 & Dec. $11 \ldots . .$. & 8.33 \\
\hline July 25. & 7.70 & Dec. $18, \ldots . . . .$. & 7.99 \\
\hline Aug. $1, \ldots \ldots \ldots \ldots \ldots \ldots \ldots \ldots \ldots \ldots$ & 8.04 & Dec. $25, \ldots \ldots \ldots \ldots \ldots \ldots \ldots \ldots \ldots \ldots \ldots \ldots \ldots \ldots$ & 7.72 \\
\hline 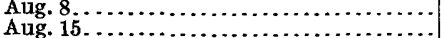 & $\begin{array}{l}8.10 \\
8.87\end{array}$ & 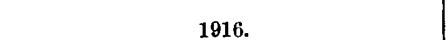 & \\
\hline 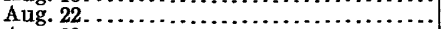 & 9.26 & Jan. 1................ & 7.42 \\
\hline Aug. 29 & 9.65 & Jan. $8 \ldots \ldots \ldots \ldots \ldots \ldots$ & 7.06 \\
\hline Sept. $5 . \ldots \ldots \ldots \ldots \ldots$ & 10.08 & 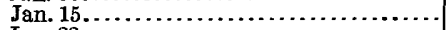 & 6.63 \\
\hline Sept. 12 & 10.39 & Jan. $22 \ldots \ldots \ldots \ldots \ldots \ldots \ldots$ & 4. 31 \\
\hline Sept. 19 & 10.75 & Jan. $29 \ldots \ldots \ldots \ldots \ldots$ & 3.39 \\
\hline Sept. 26.. & 11.11 & Feb. $5 \ldots \ldots \ldots \ldots \ldots \ldots \ldots \ldots$ & 2.92 \\
\hline Oct. 3... & 11.48 & 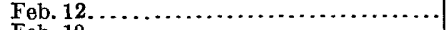 & 2.61 \\
\hline Oct. $10 \ldots \ldots \ldots$ & 11.74 & 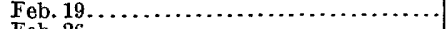 & 2.36 \\
\hline Oct. 17.......... & 11.87 & Feb. 26............... & 2.20 \\
\hline 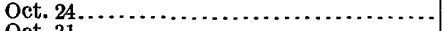 & 12.03 & $\ldots \ldots \ldots \ldots$ & 1.98 \\
\hline 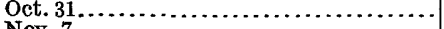 & 12.11 & 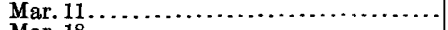 & 1.81 \\
\hline$\ldots \ldots \ldots \ldots \ldots \ldots \ldots$ & 12.17 & Mar. 18. . . . . . . . . . . . . . . & 1.78 \\
\hline$\ldots \ldots \ldots \ldots \ldots \ldots \ldots \ldots$ & 12. 20 & Mar. $25 \ldots \ldots \ldots \ldots \ldots \ldots \ldots \ldots \ldots \ldots \ldots \ldots \ldots$ & 1.68 \\
\hline 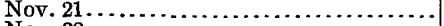 & 12. 32 & Apr. $1 \ldots \ldots \ldots \ldots \ldots \ldots \ldots \ldots \ldots \ldots \ldots \ldots \ldots \ldots$ & 1.62 \\
\hline 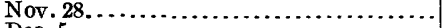 & 12.36 & Apr. $8 \ldots \ldots \ldots \ldots \ldots \ldots$ & 1.62 \\
\hline$\ldots \ldots \ldots \ldots \ldots \ldots \ldots \ldots \ldots$ & 12.44 & $\ldots \ldots \ldots \ldots \ldots \ldots \ldots \ldots \ldots$ & 1. 63 \\
\hline Dec. $12 \ldots . . .$. & 12.46 & Apr. $22 \ldots \ldots \ldots \ldots \ldots \ldots$ & 1.63 \\
\hline Dec. $19 . \ldots \ldots \ldots \ldots \ldots \ldots \ldots \ldots$ & 12.45 & Apr. $29 \ldots \ldots \ldots \ldots \ldots \ldots \ldots \ldots \ldots \ldots \ldots \ldots$ & 1.68 \\
\hline Dec. $26 . . . \ldots \ldots \ldots \ldots \ldots \ldots \ldots \ldots \ldots$ & 12.37 & 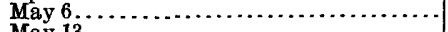 & 1.69 \\
\hline 1915. & & May $20 \ldots \ldots \ldots \ldots \ldots$ & 1.82 \\
\hline Jan. 2... & 12.08 & May $27 . \ldots . \ldots \ldots \ldots$ & 1.83 \\
\hline Jan. $9 \ldots$ & 11.89 & June $3 \ldots \ldots \ldots \ldots \ldots$ & 1.83 \\
\hline Jan. $16 \ldots \ldots . . .$. & 11.72 & 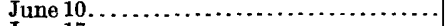 & 1.83 \\
\hline Jan. $23 \ldots \ldots \ldots \ldots \ldots \ldots \ldots \ldots \ldots \ldots$ & 11.53 & June 17 . . . . . . . . . . . . . . . . & 1.87 \\
\hline 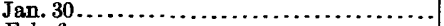 & 11.38 & June $24 \ldots . . \ldots \ldots .$. & 1.90 \\
\hline 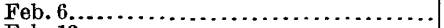 & 10.33 & July 1. & 1.97 \\
\hline Feb. $13 . \ldots \ldots \ldots \ldots \ldots \ldots$ & 7.89 & July $8 \ldots \ldots \ldots \ldots \ldots \ldots \ldots$ & 2.05 \\
\hline Feb. $20 \ldots . .$. & 6.43 & July $15 \ldots \ldots \ldots \ldots \ldots \ldots$ & 2.12 \\
\hline Feb. $27 \ldots \ldots$ & 5.89 & July $22 \ldots \ldots \ldots \ldots \ldots \ldots \ldots$ & 2.22 \\
\hline Mar.6........ & 5.44 & July $29 \ldots \ldots \ldots \ldots \ldots \ldots \ldots \ldots$ & 2.40 \\
\hline Mar. 13....... & 5.17 & Aug. $5, \ldots \ldots \ldots \ldots \ldots \ldots \ldots \ldots \ldots \ldots \ldots$ & 2.52 \\
\hline Mar. 20....... & 5.00 & Aug. 12. . . . . . . . . . . . . & 2.71 \\
\hline Mar. 27. & 4.92 & Aug. $19 . \ldots \ldots \ldots \ldots \ldots \ldots \ldots$ & 2.86 \\
\hline Apr. 3. & 4. 77 & Aug. $26 \ldots \ldots \ldots \ldots \ldots \ldots \ldots$ & 3.01 \\
\hline$\ldots \ldots \ldots \ldots \ldots$ & 4. 68 & 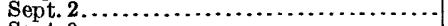 & 3.02 \\
\hline 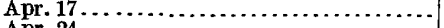 & 4.61 & 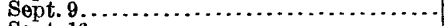 & 3.04 \\
\hline 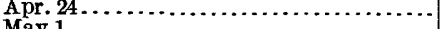 & 4.50 & Sept. $16 \ldots \ldots \ldots \ldots \ldots \ldots \ldots \ldots \ldots \ldots$ & 3.06 \\
\hline$\ldots \ldots \ldots \ldots \ldots \ldots$ & 4.31 & Sept. $23 \ldots \ldots \ldots \ldots \ldots \ldots \ldots \ldots \ldots \ldots$ & 3.13 \\
\hline 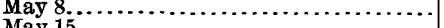 & 4.05 & Sept. $30 \ldots \ldots \ldots \ldots \ldots \ldots$ & 3.18 \\
\hline 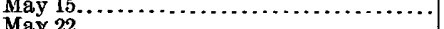 & 3.93 & Oct. $7 \ldots \ldots \ldots \ldots \ldots \ldots \ldots \ldots$ & 3.15 \\
\hline 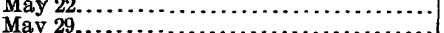 & 3.89 & Oct. $14{ }_{1} \ldots \ldots \ldots \ldots \ldots$ & 2.98 \\
\hline $\begin{array}{l}\text { Muay } 29 . . . \\
\text { June } 5 \ldots . . .\end{array}$ & $\begin{array}{l}3.88 \\
3.84\end{array}$ & Oct. $21 \ldots \ldots \ldots \ldots \ldots \ldots$ & \\
\hline June 12. & $\begin{array}{l}3.94 \\
3.97\end{array}$ & $\begin{array}{l}\text { Uet. } 28 \ldots . . \\
\text { Nov. } 4 \ldots\end{array}$ & $\begin{array}{l}2.40 \\
2.36\end{array}$ \\
\hline June 19......... & 4.23 & Nov. $11 . \ldots \ldots \ldots$ & 2.33 \\
\hline June $26 . . . . .$. & 4. 30 & Nov. $18 \ldots \ldots \ldots$ & 2.32 \\
\hline July $3 \ldots \ldots \ldots$ & 4.34 & Nov. $25 \ldots . .$. & 2.33 \\
\hline 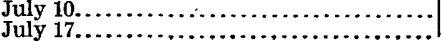 & $\begin{array}{l}4.36 \\
4.49\end{array}$ & 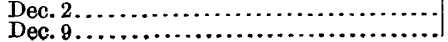 & $\begin{array}{l}2.34 \\
2.34\end{array}$ \\
\hline
\end{tabular}


Record of water levels in the Williams well, about $4 \frac{1}{2}$ miles east of San Bernardino-Contd.

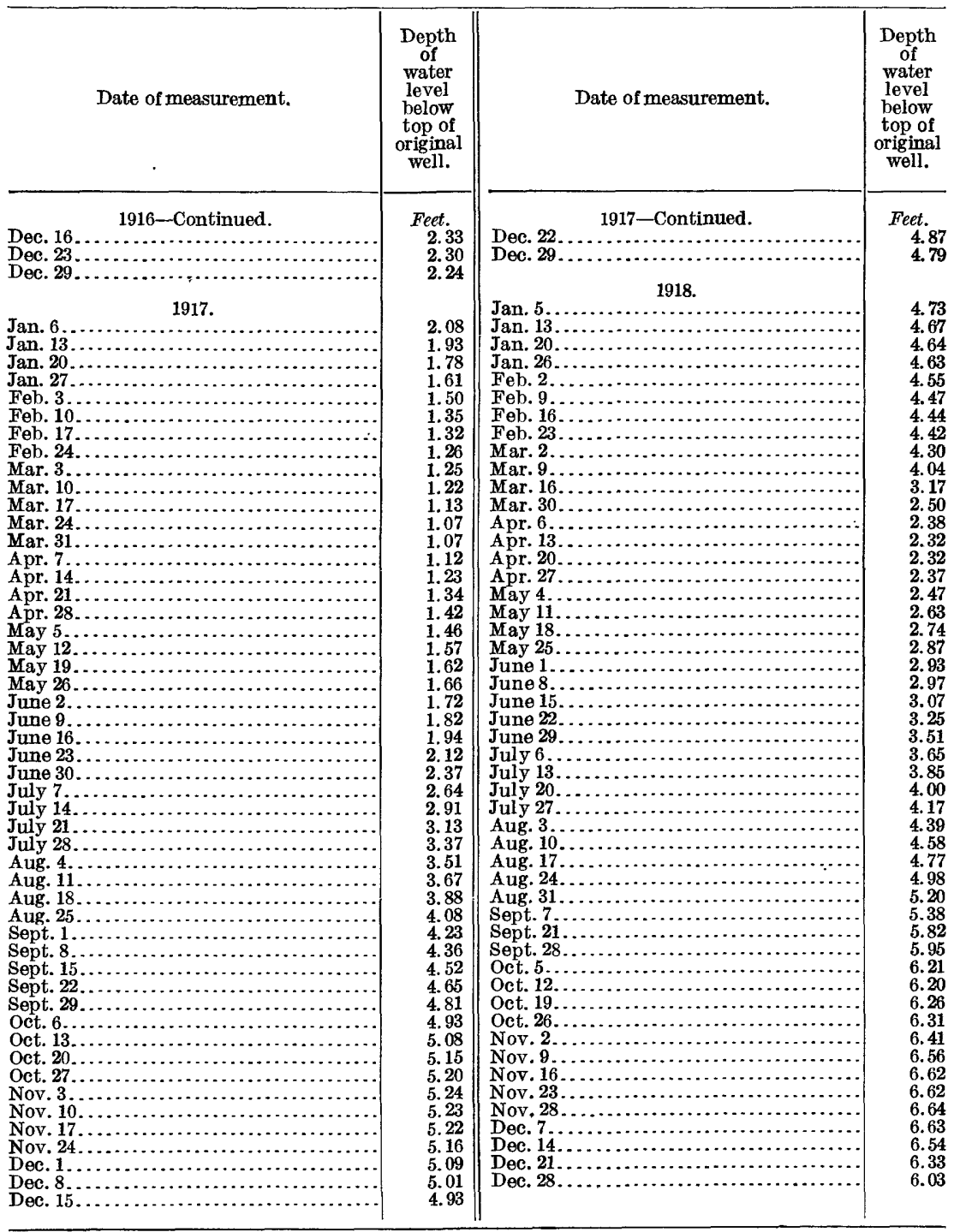




\section{SAN DIFGO COUNTY.}

In addition to the records of wells in the valley of southern California, records are given below for a few wells in the western part of San Diego County. Observations on the water levels in wells in that region were begun in 1912 by Arthur J. Ellis and Charles H. Lee. The data for many of these wells for the years 1912 to 1915 were published in Water-Supply Paper 446, in the form of diagrams showing graphically the fluctuations of the water table. Many wells that were measured during that period were destroyed by the floods in January, 1916 . In the present report the basic data for all wells that are still being measured are given complete since 1912 , and data for a few new wells are included. The numbers correspond to those in Water-Supply Paper 446.

Records of water levels in wells in San Diego County, California.

C7a. Well at Fairview Hotel, SW. $\frac{1}{4}$ sec. 20, T. 10 S., R. 3 W., Bonsall.

[Dug well, 3 feet in diameter, dry rock curb. Bench mark: Top of 2-mch cover over dry rock curb. Altitude of bench mark, 162.14 feet above sea level. Companion for C7 in Water-Supply Paper 446, Tablo 30, p. 126.]

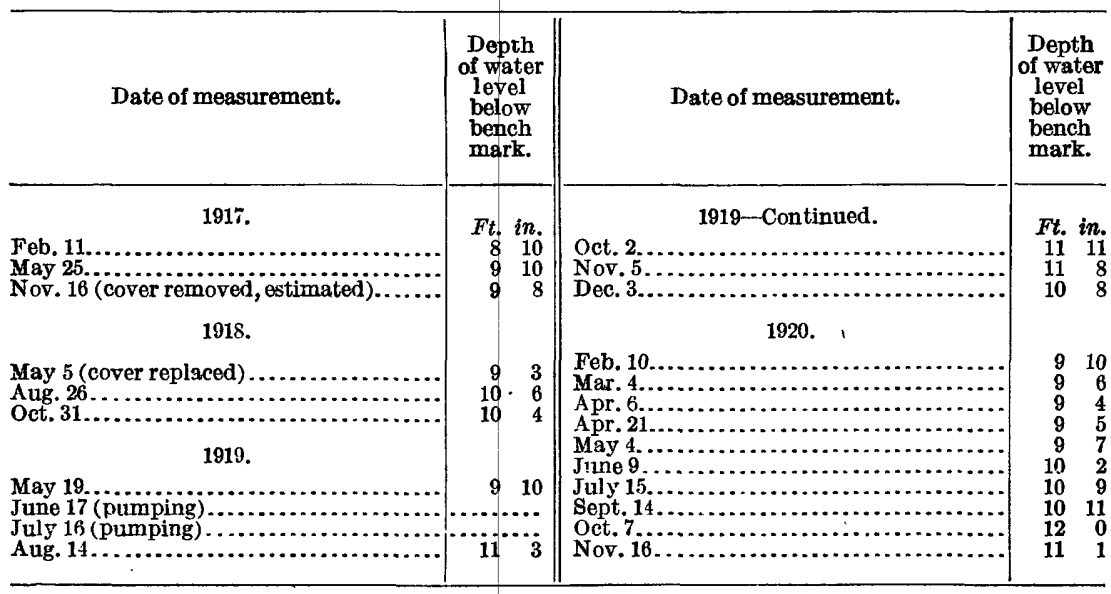


Records of water levels in wells in San Diego County, California-Continued.

C9. Well at east end of Monseratte rancho.

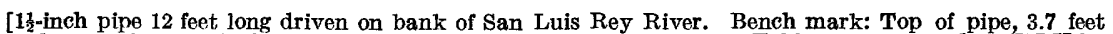
above surface, 268.72 feet above sea level. Water-Supply Paper 446, Table 31, p. 130, and Pl. XLII.]

\begin{tabular}{|c|c|c|c|}
\hline Date of measurement. & $\begin{array}{l}\text { Depth } \\
\text { of water } \\
\text { level } \\
\text { below } \\
\text { bench } \\
\text { mark. }\end{array}$ & Date of measurement. & $\begin{array}{l}\text { Depth } \\
\text { of water } \\
\text { level } \\
\text { below } \\
\text { bench } \\
\text { mark. }\end{array}$ \\
\hline 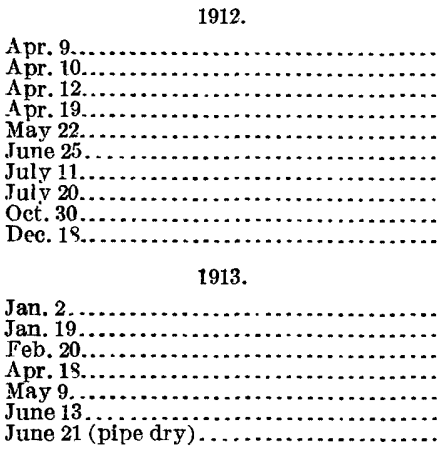 & $\begin{array}{rr}\text { Ft. } & \text { in. } \\
4 & 10 \\
4 & 10 \\
1 & 1 \\
4 & 3 \\
5 & 0 \\
5 & 2 \\
5 & 5 \\
7 & 5 \\
1 & 10 \\
5 & 3 \\
& \\
& \\
4 & 10 \\
4 & 11 \\
4 & 11 \\
5 & 0 \\
5 & 2 \\
7 & 7 \\
\ldots\end{array}$ & 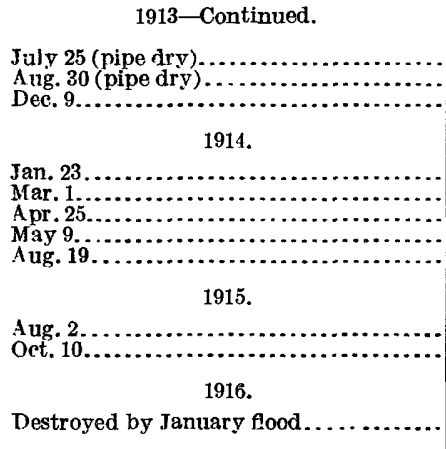 & $\begin{array}{rr}4 & 11 \\
4 & 11 \\
5 & 3 \\
5 & 6 \\
7 & 3 \\
& \\
& \\
4 & 9 \\
4 & 7\end{array}$ \\
\hline
\end{tabular}

C10. Well in SW. $\frac{1}{4}$ sec. 32, T. 9 S., R. 2 W., near Pala, locally known as Dal Higgins ranch.

[Dug well. Bench mark: 10-penn 313.06 feet above sea level. Water-Supply Paper 446, Table 31, p. 130, and Pl. XLII.]

\begin{tabular}{|c|c|c|c|}
\hline Date of measurement. & $\begin{array}{c}\text { Depth } \\
\text { of water } \\
\text { level } \\
\text { below } \\
\text { bench } \\
\text { mark. }\end{array}$ & Date of measurement. & $\begin{array}{c}\text { Depth } \\
\text { of water } \\
\text { level } \\
\text { below } \\
\text { bench } \\
\text { mark. }\end{array}$ \\
\hline 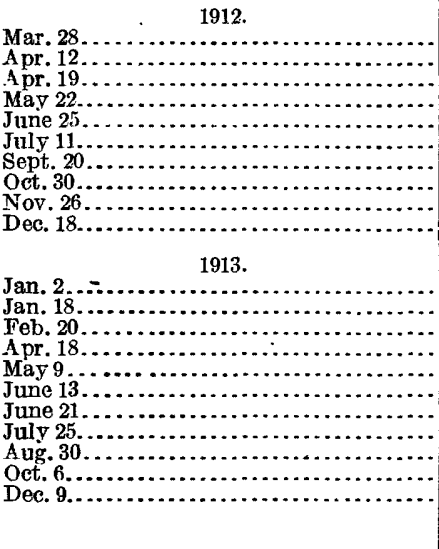 & $\begin{array}{rr}\text { Ft. } & \text { in. } \\
7 & 4 \\
5 & 10 \\
5 & 8 \\
6 & 5 \\
6 & 10 \\
6 & 11 \\
6 & 11 \\
6 & 8 \\
6 & 10 \\
6 & 10 \\
& \\
& \\
6 & 6 \\
6 & 8 \\
6 & 4 \\
6 & 9 \\
6 & 10 \\
7 & 2 \\
7 & 0 \\
7 & 0 \\
7 & 1 \\
6 & 6 \\
6 & 9\end{array}$ & 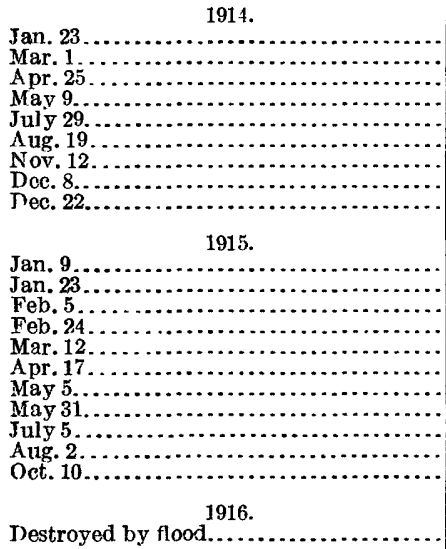 & $\begin{array}{rr}F t . & i n . \\
\mathbf{6} & \mathbf{5} \\
\mathbf{5} & \mathbf{6} \\
\mathbf{5} & 8 \\
\mathbf{6} & 7 \\
7 & 7 \\
7 & 2 \\
\mathbf{6} & \mathbf{1 0} \\
\mathbf{6} & 9 \\
\mathbf{6} & 9 \\
& \\
& \\
6 & 8 \\
6 & 8 \\
\mathbf{5} & \mathbf{3} \\
4 & \mathbf{1 0} \\
\mathbf{5} & 5 \\
\mathbf{5} & \mathbf{9} \\
\mathbf{5} & 1 \\
\mathbf{5} & \mathbf{6} \\
\mathbf{6} & 1 \\
\mathbf{6} & \mathbf{5} \\
\mathbf{6} & \mathbf{2}\end{array}$ \\
\hline
\end{tabular}


Records of water levels in wells in San Diego County, California-Continued.

F3. County well in SW. $\frac{1}{4}$ sec. 18, T. 11 S., R. 4 W., San Luis Rey.

[Dug well, 12 feet 8 inches deep, 5 by 5 feet in cross section. Bench mark: Upper surface of cover, south west corner of wood curb 3 feet above surface, 35.10 feet above sea level. Water-Supply Paper 446 Table 31, p. 130.]

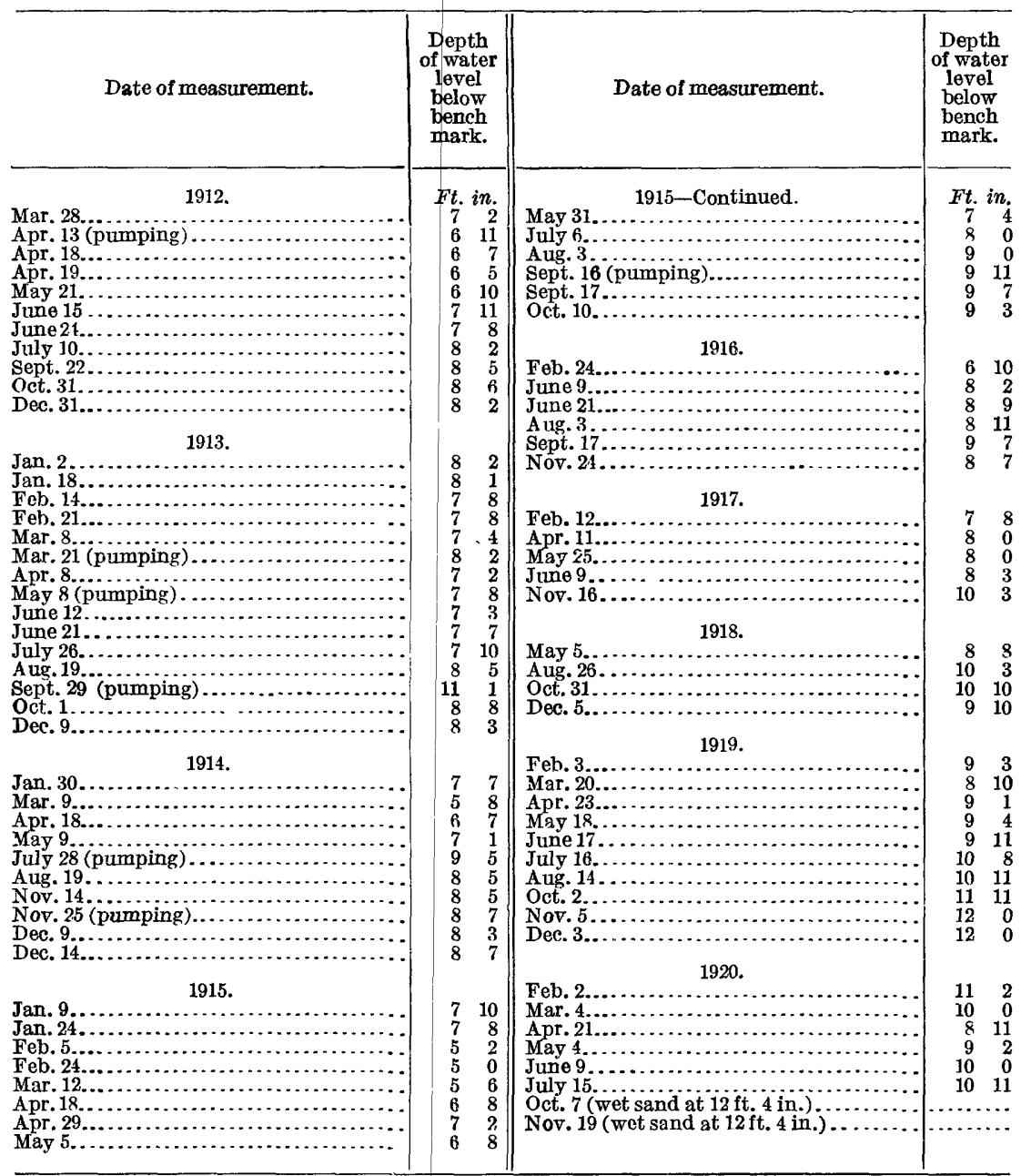

$1820^{\circ}-21-$ WSP $468-9$ 


\section{Records of water levels in wells in San Diego County, California-Continued.}

\section{F13. Charles Forman, SW. $\frac{1}{4}$ sec. 18, T. 11 S., R. 4 W., San Luis Rey.}

[Dug well, 10.3 feet deep, 3 by 3 feet in cross section. Bench mark: Two copper tacks in top of curb post at northwest corner of curb at surface, 27.87 feet above sea level. Water-Supply Paper 446, Table 31, p. 130, and Pl. XLIY.]

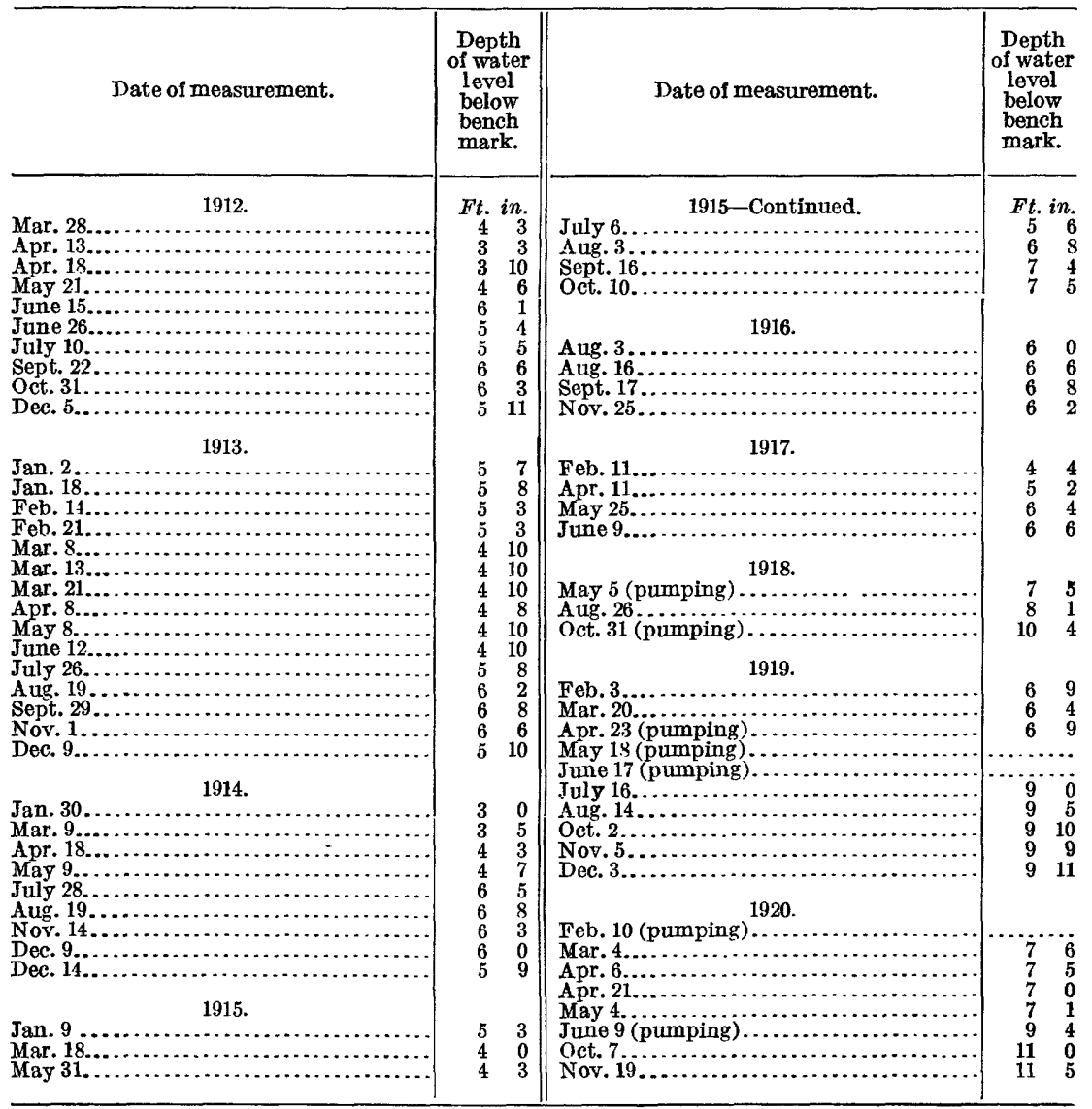


Records of water levels in wells in San Diego County, California-Continued.

F17. Charles Forman, SW. $\frac{1}{4}$ sec. 8, T. 11 S., R. 4 W., San Luis Rey.

[Dug well, 14.8 feet deep, 7 feet in diameter. Bench mark: North side of cover of opening through wooden deck 4 feet above surface, 51.82 feet above sea level. Water-Supply Paper 446, Table 31, p. 130, and Pl. XLII.]

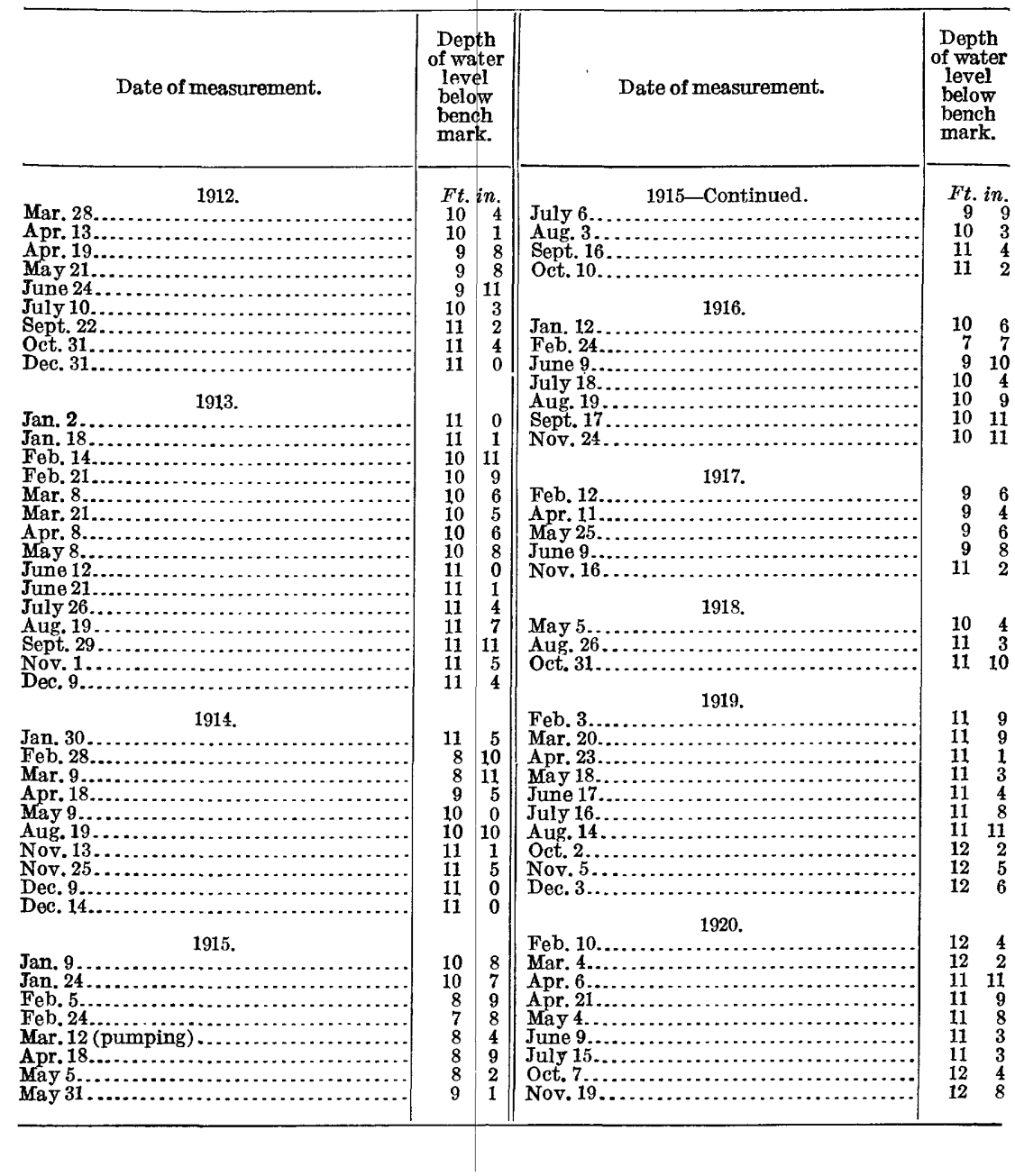


Records of water levels in wells in San Diego County, California-Continued.

F20. Edm. E. Riehmond, SE. $\frac{1}{4}$ sec. 5, T. 11 S., R. 4 W., San Luis Rey.

[Dug well, 12.3 feet deep. Bench mark: Tack in top of curb at northwest corner, under cover 1 foot above surface, 64.55 feet above sea level. Water-Supply Paper 446, Table 31, p. 130, and Pl. XLII.]

\begin{tabular}{|c|c|c|c|}
\hline Date of measurement & $\begin{array}{l}\text { Depth } \\
\text { of water } \\
\text { level } \\
\text { below } \\
\text { bench } \\
\text { mark. }\end{array}$ & Date of measurement & $\begin{array}{l}\text { Depth } \\
\text { of water } \\
\text { level } \\
\text { below } \\
\text { bench } \\
\text { mark. }\end{array}$ \\
\hline 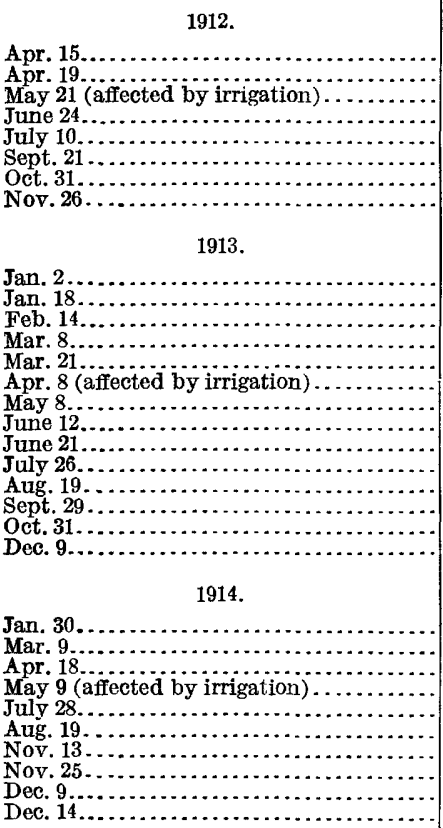 & $\begin{array}{rr}10 & 7 \\
10 & 11 \\
10 & 5 \\
9 & 1 \\
8 & 4 \\
4 & 3 \\
7 & 5 \\
8 & 4 \\
8 & 11 \\
9 & 4 \\
9 & 11 \\
10 & 6 \\
10 & 8 \\
11 & 4\end{array}$ & 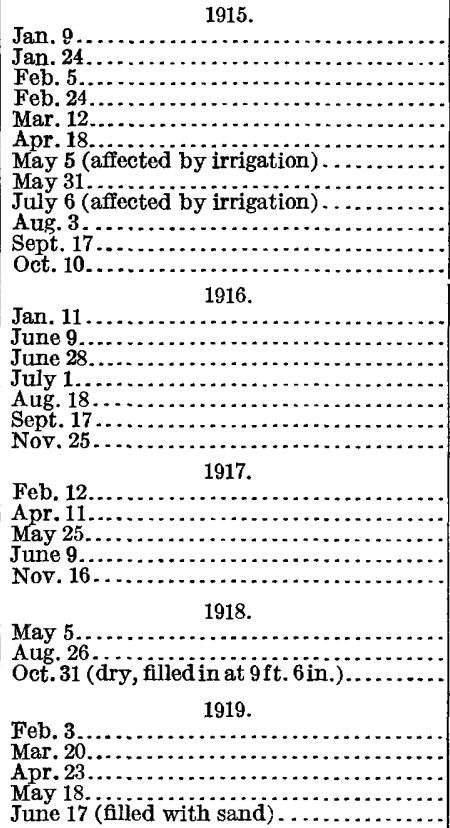 & $\begin{array}{rr}8 & \mathbf{1} \\
8 & 7 \\
7 & \mathbf{8} \\
7 & \mathbf{1 0} \\
7 & \mathbf{9} \\
8 & 8 \\
8 & 10 \\
& \\
8 & \mathbf{5} \\
8 & 6 \\
8 & 9 \\
8 & \mathbf{1 0} \\
10 & \mathbf{2} \\
& \\
& \\
\mathbf{9} & \mathbf{0} \\
\mathbf{1 0} & \mathbf{0} \\
\ldots . . .\end{array}$ \\
\hline
\end{tabular}




\section{Records of water levels in wells in San Diego County, California-Continued.}

F21. Escondido Mutual Water Co., SW. $\frac{1}{4}$ sec. 4, T. 11 S., R. 4 W., San Luis Rey.

[Dug well, 13.5 deep, 4 by 4 feet in cross section. Bench mark: Top of 3 by 4 inch timber under cover 2 feet above surface, 68.94 feet above sea level. Water-Supply Paper 446, Table 31, p. 130.]

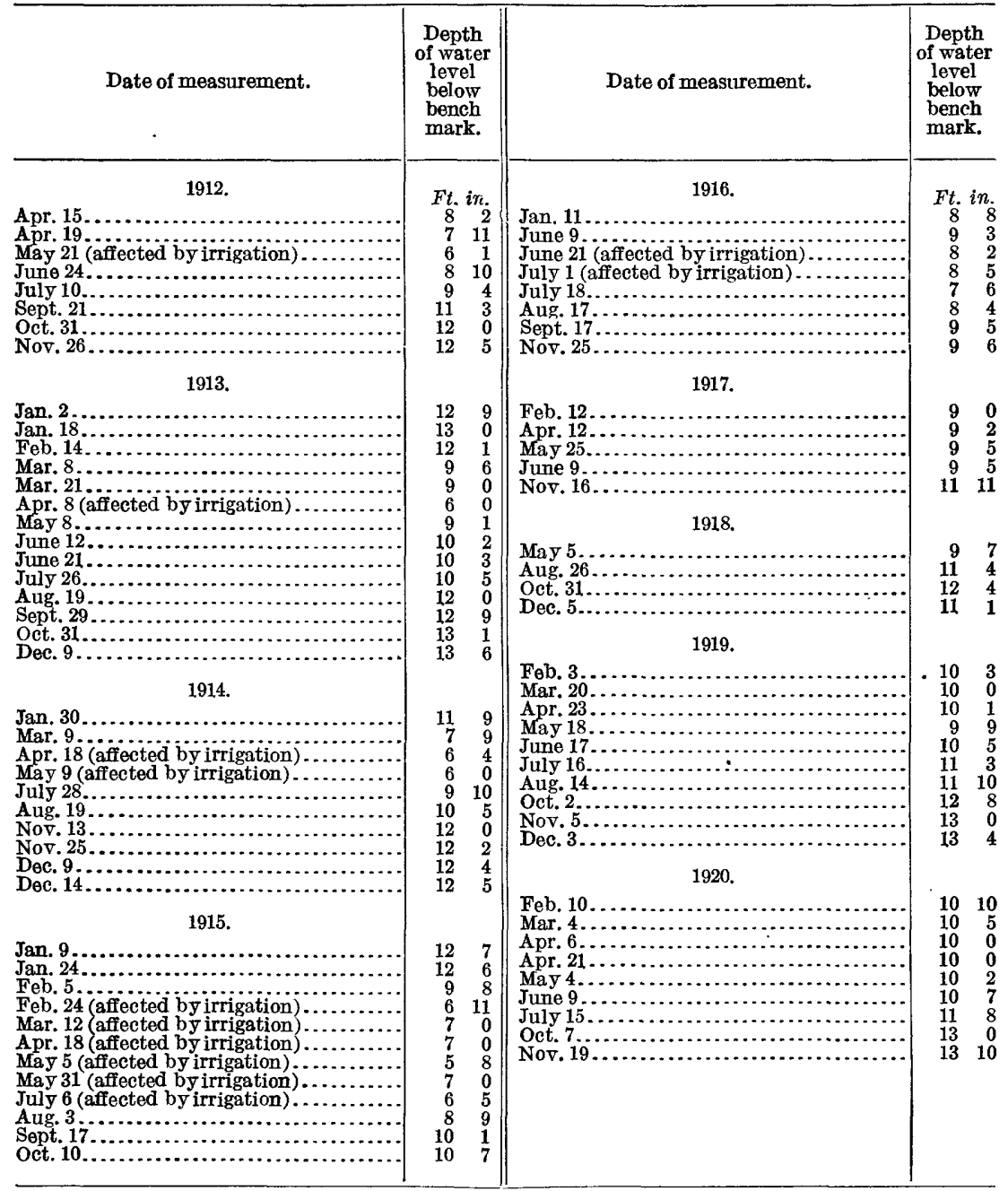




\section{WATER LEVELS IN WELLS IN SOUTHERN CALIFORNIA.}

Records of water levels in wells in San Diego County, California-Continued.

G37. Santa Fe ranch, San Dieguito land grant, San Dieguito Valley.

[Drilled well in bottom of shallow pit, casing 10 inches in d ameter. Bench mark: Top of concrete at cast-iron cover over casing, 39.88 feet above sea level. Altitude of surface 43 feet above sea level in 1917. From Feb. 10, 1915, to Mar. 3, 1915, measurements made froln surface. Water-Supply Paper 446, Table 33, p. 134, and Pl. XLI.]

\begin{tabular}{|c|c|c|c|}
\hline Date of measurement. & $\begin{array}{l}\text { Depth } \\
\text { of water } \\
\text { level } \\
\text { below } \\
\text { bench } \\
\text { mark. }\end{array}$ & Date of measurement. & $\begin{array}{l}\text { Depth } \\
\text { of water } \\
\text { level } \\
\text { below } \\
\text { bench } \\
\text { mark. }\end{array}$ \\
\hline & Ft. in. & & Ft. in. \\
\hline Jan. 26... & $10^{7}$ & Feb. $24 \ldots$ & 23 \\
\hline $\operatorname{Tar} 3$ & 83 & Feb. 25 . & \\
\hline May 1 & 104 & Feb. 26 . & 1 \\
\hline $1 \ldots$ & 105 & Feb. 27. & 1 \\
\hline $15 \ldots$ & 118 & Feb. 28 & 1 \\
\hline ne $30 .$. & 122 & Mar. 1.... & 1 \\
\hline & $\begin{array}{ll}12 & 6 \\
13 & 0\end{array}$ & $\begin{array}{l}\text { Mar. } 5 \ldots \\
\text { Mar. } 6 \ldots\end{array}$ & $\begin{array}{l}1 \\
1\end{array}$ \\
\hline ug. 15... & 128 & Mar. 7... & 1 \\
\hline Aug. 31. & $13 \quad 9$ & Mar. $8 .$. & 1 \\
\hline 15. & 139 & Mar. $10 .$. & 1 \\
\hline pt. 30. & 139 & Mar. 11. . & 1 \\
\hline 15.. & $12 \quad 1$ & Mar. 12. & 10 \\
\hline & 1210 & Mar. 13. & 10 \\
\hline Tov. 15. & 12 & Mar. 14 & 10 \\
\hline Nov. 30 & 119 & Mar. 18.... & 110 \\
\hline $\begin{array}{l}\text { Dec. } 15 \ldots . . \\
\text { Dec. } 31 . . . .\end{array}$ & $\begin{array}{ll}11 & 5 \\
11 & 4\end{array}$ & $\begin{array}{l}\text { Mar. } 21 \ldots \ldots \\
\text { Mar. } 22 \ldots . . .\end{array}$ & $\begin{array}{ll}2 & 2 \\
2 & 2\end{array}$ \\
\hline $20.01 .$. & & Mar. $31 . . .$. & 2 \\
\hline Jan. 15.... & & Apr. $1 \ldots .$. & 2 \\
\hline & 5 & $191 ?$ & \\
\hline Feb. 15... & 4 & May $15 .$. & 6 \\
\hline $15 \ldots$ & & May 28. & \\
\hline $1 \ldots .$. & & June 6. - & 511 \\
\hline $15 .$. & $\begin{array}{ll}3 & 3\end{array}$ & & 59 \\
\hline & $2 \quad 11$ & $10 \ldots$ & 5 \\
\hline May $15 \ldots$. & 27 & June $21 \ldots \ldots$ & $\begin{array}{l}5 \\
6\end{array}$ \\
\hline $1, \ldots$. & $\begin{array}{ll}4 & 1 \\
5 & 7\end{array}$ & July $7 \ldots \ldots \ldots$ & $\begin{array}{ll}0 \\
6 & 10\end{array}$ \\
\hline$\cdots$ & & $\begin{array}{l}\text { Aug. } 1 . \ldots \ldots \\
\text { Aug. } 6 . \ldots .\end{array}$ & 77 \\
\hline & & $13 \ldots$ & $\begin{array}{ll}7 & 11\end{array}$ \\
\hline & 10 & 2. & 88 \\
\hline & 11 & & 8 \\
\hline & 811 & & 810 \\
\hline $\mathrm{Se}$ & 4 & Sept. 24. & 91 \\
\hline & 85 & Oc & 8 \\
\hline & 810 & Oct. 13... & 8 \\
\hline Oc & 3 & Oct. $20 \ldots$ & 8 \\
\hline & 810 & & 8 \\
\hline & 11 & & 8 \\
\hline Dec. $15 \ldots . . . .$. & $\begin{array}{ll}8 & 11\end{array}$ & Nov. $10 \ldots .$. & $8 \quad 8$ \\
\hline Dec. $31 \ldots . . .$. & $8 \quad 11$ & $\begin{array}{l}\text { Nov. } 17 \ldots . . \\
\text { Nov. } 24 \ldots \ldots\end{array}$ & $\begin{array}{rr}8 & 10 \\
9 & 0\end{array}$ \\
\hline 1915 & & Dec. $1 . .$. & 9 \\
\hline Jan. 15.. & 1 & & 9 \\
\hline $\mathrm{Jan}$ & & Dec. $15 .$. & $\begin{array}{ll}9 & 11 \\
0\end{array}$ \\
\hline & $\begin{array}{ll}3 & 8\end{array}$ & Dec. $22 \ldots \ldots \ldots$ & $\begin{array}{ll}9 & 8 \\
0 & 2\end{array}$ \\
\hline & $\begin{array}{ll}2 & 0 \\
& 6\end{array}$ & Dec. $29 . \ldots \ldots$. & 9 \\
\hline Feb & & 1918. & \\
\hline Feb. 5... & $1 \quad 11$ & $\operatorname{Jan} .5 \ldots$ & 9 \\
\hline Feb. $6 \ldots$ & 1 & Jan. $12 \ldots$ & 9 \\
\hline & 2 & Jan. $19 .$. & 9 \\
\hline & 4 & & 9 \\
\hline$\cdots$ & 22 & Feb. $2 \ldots \ldots$ & $\begin{array}{l}7 \\
6\end{array}$ \\
\hline (n.......... & $\begin{array}{l}5 \\
0\end{array}$ & 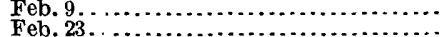 & $\begin{array}{l}6 \\
6\end{array}$ \\
\hline $\begin{array}{l}\text { Feb. } 11 \ldots . . \\
\text { Feb. } 12 . . .\end{array}$ & 4 & Mar. $2 . \ldots \ldots$ & 6 \\
\hline Fel & 5 & Mar. 9... & 5 \\
\hline & 1 & 16. & 5 \\
\hline & 211 & & 5 \\
\hline & 3 & Ap & 6 \\
\hline & 1 & $.13 .$. & 6 \\
\hline & & & 6 \\
\hline .......... & 15 & Apr. 27... & 6 \\
\hline .... & $1 \stackrel{3}{3}$ & May $4 \ldots$ & 7 \\
\hline$\ldots .$. & 10 & ……...... & 7 \\
\hline Feb. & $\begin{array}{ll}1 & 7 \\
1 & 0\end{array}$ & May 25.. & $\begin{array}{l}7 \\
7\end{array}$ \\
\hline & $\begin{array}{ll}1 & 9\end{array}$ & 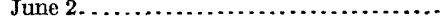 & 710 \\
\hline
\end{tabular}


Records of water levels in wells in San Diego County, California-Continued.

G37. Santa Fe ranch-Continued.

\begin{tabular}{|c|c|c|c|}
\hline Date of measurement. & $\begin{array}{l}\text { Depth } \\
\text { of water } \\
\text { level } \\
\text { below } \\
\text { bench } \\
\text { mark. }\end{array}$ & Date of measurement. & $\begin{array}{c}\text { Depth } \\
\text { of water } \\
\text { level } \\
\text { below } \\
\text { bench } \\
\text { mark. }\end{array}$ \\
\hline 1918-Continued. & Ft. in. & 1919-Continued. & Ft. in. \\
\hline June $9 \ldots \ldots \ldots \ldots \ldots \ldots \ldots \ldots \ldots$ & & $\ldots \ldots \ldots \ldots \ldots \ldots \ldots$, & $7 \quad 10$ \\
\hline 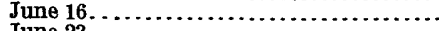 & 81 & Feb. $1 \ldots \ldots \ldots \ldots \ldots \ldots \ldots \ldots \ldots \ldots$ & 7 \\
\hline $\begin{array}{l}\text { June } 23 . \ldots \ldots \ldots \ldots \\
\text { June } 30 \ldots \ldots \ldots \ldots\end{array}$ & $\begin{array}{ll}8 & 5 \\
8 & 5\end{array}$ & $\begin{array}{l}\text { Feb. } 8, \ldots \ldots \\
\text { Feb. } 15, \ldots \ldots\end{array}$ & $\begin{array}{rr}7 & 9 \\
7 & 10\end{array}$ \\
\hline July $7 \ldots$ & $\begin{array}{ll}8 & 5 \\
8 & 11\end{array}$ & Feb. $22 \ldots \ldots$ & 80 \\
\hline July $14 \ldots \ldots \ldots \ldots \ldots \ldots \ldots \ldots$ & & Mar. 1. & 710 \\
\hline July $19 . \ldots \ldots \ldots \ldots$ & 9 & 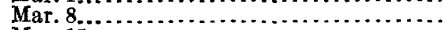 & 79 \\
\hline July $27 \ldots \ldots \ldots \ldots \ldots \ldots \ldots \ldots \ldots$ & 10 & 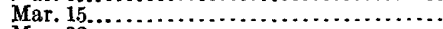 & 7 \\
\hline Aug. 4 . . . . & 10 & 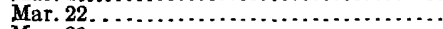 & 8 \\
\hline 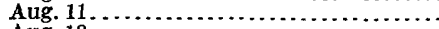 & 10 & Mar. $29 . . . \ldots \ldots \ldots$ & 8 \\
\hline Aug. 18......... & 10 & 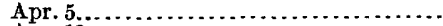 & 8 \\
\hline Aug. 25. & 10 & Apr. $12 \ldots \ldots \ldots \ldots \ldots \ldots$ & 8 \\
\hline Sept. $1 \ldots$ & 10 & Apr. $19 \ldots \ldots \ldots \ldots \ldots \ldots$ & 8 \\
\hline Sept. $7 \ldots \ldots \ldots$ & 104 & Apr. 26. & 8 \\
\hline Sept. $15 \ldots \ldots \ldots \ldots \ldots \ldots \ldots \ldots$ & 911 & May 3.... & 8 \\
\hline 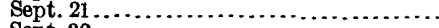 & 100 & May $10 \ldots$ & 8 \\
\hline ........................ & 10 & May 17... & 8 \\
\hline$\ldots \ldots . . . . .$. & 10 & May $24 \ldots$ & 8 \\
\hline 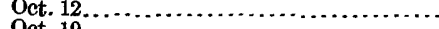 & 10 & $\ldots \ldots \ldots \ldots \ldots \ldots \ldots$ & 9 \\
\hline 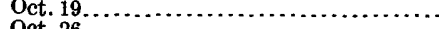 & & June $7 \ldots \ldots \ldots$ & 9 \\
\hline Oct. $26 \ldots \ldots \ldots \ldots \ldots \ldots$ & & June $14 \ldots \ldots \ldots \ldots \ldots \ldots \ldots . . . . . . .$. & 9 \\
\hline 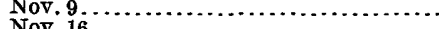 & 86 & June $21 \ldots \ldots \ldots \ldots \ldots$ & 9 \\
\hline $\begin{array}{l}\text { Nov. } 16 \\
\text { Nov. } 24 .\end{array}$ & $\begin{array}{lr}8 & 4 \\
7 & 10\end{array}$ & June $28 \ldots \ldots \ldots \ldots \ldots$ & 9 \\
\hline Dec. $7 \ldots$ & 6 & 1920. & \\
\hline Dec. 14... & $\begin{array}{ll}7 & 11\end{array}$ & Feb. 10............. & 10 \\
\hline 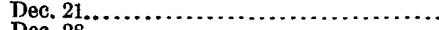 & 711 & Mar. $9 . \ldots \ldots \ldots \ldots \ldots$ & 10 \\
\hline 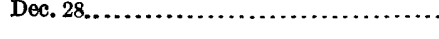 & 710 & Apr. $10 \ldots \ldots \ldots \ldots$ & $\begin{array}{l}10 \\
10\end{array}$ \\
\hline 1919. & & June 10 . & 11 \\
\hline $\operatorname{Jan} 4 . \ldots$. & & July $10 \ldots \ldots \ldots \ldots \ldots$ & 10 \\
\hline $\begin{array}{ll}\text { Jan. } 11 \ldots . . . \\
\text { Jan. } 18 \ldots\end{array}$ & 80 & 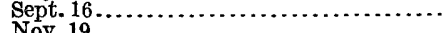 & 11 \\
\hline a. 1 C & 81 & Nov. $19, \ldots \ldots \ldots \ldots \ldots \ldots \ldots \ldots \ldots$ & 11 \\
\hline
\end{tabular}

J. H. Dinsmore, SE. $\frac{1}{4}$ SE. $\frac{1}{\frac{1}{4}}$ sec. 6, T. 14 S., R. 3 W., San Dieguito Valley.

[Driven pipe, 2 inches in diameter, 18 feet deep. Establislied by the San Dieguito Mutual Water Co. for observing the depth of water plane. Bencil mark: Top of casing 3 feet 1 inch above surface, 20.98 feet above sea level.]

\begin{tabular}{|c|c|c|c|}
\hline Date of measurement. & $\begin{array}{l}\text { Deptli } \\
\text { of water } \\
\text { level } \\
\text { below } \\
\text { bench } \\
\text { mark. }\end{array}$ & Date of measurement. & $\begin{array}{c}\text { Depth } \\
\text { of water } \\
\text { level } \\
\text { below } \\
\text { bench } \\
\text { mark. }\end{array}$ \\
\hline 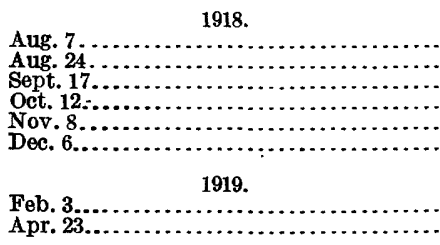 & $\begin{array}{rr}\text { Ft. } & \text { in. } \\
8 & 2 \\
8 & 4 \\
8 & 8 \\
8 & 10 \\
8 & 10 \\
8 & 7 \\
& \\
8 & 1 \\
7 & 11\end{array}$ & 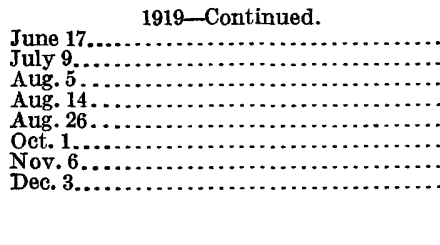 & $\begin{array}{rr}\text { Ft. } & \text { in. } \\
8 & 7 \\
8 & 11 \\
9 & 3 \\
9 & 4 \\
9 & 4 \\
9 & 7 \\
9 & 10 \\
9 & 10\end{array}$ \\
\hline
\end{tabular}


Records of water levels in wells in San Diego County, California-Continued.

H1. Roberts place, NE. $\frac{1}{4}$ SW. $\frac{1}{\frac{1}{4}}$ sec. 33, T. 12 S., R. 1 W., San Pasqual.

[Curbed well, 24feet 6 inches deep, 4 by 4 feet in cross section; method of lift, gasoline engine and centrifugal pump. Bench mark: Top of 3 by 4 inch curb post at northwest corner, 3 feet 6 inches above surface, 382.73 feet above sea level. Water-Supply Paper 446, Table 31, p. 130, and Pl. XLI.]

\begin{tabular}{|c|c|c|c|}
\hline Date of measurement. & $\begin{array}{c}\text { Depth } \\
\text { of water } \\
\text { level } \\
\text { below } \\
\text { bench } \\
\text { mark. }\end{array}$ & Date of measurement. & $\begin{array}{l}\text { Depth } \\
\text { of water } \\
\text { level } \\
\text { below } \\
\text { bench } \\
\text { mark. }\end{array}$ \\
\hline 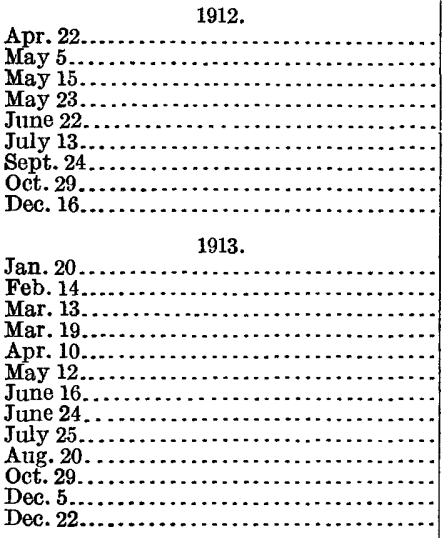 & $\begin{array}{rr}\text { Ft. } & \text { in. } \\
4 & 10 \\
5 & 2 \\
5 & 0 \\
5 & 0 \\
5 & 10 \\
5 & 8 \\
6 & 9 \\
6 & 9 \\
6 & 6 \\
& \\
5 & 10 \\
5 & 6 \\
5 & 0 \\
5 & 1 \\
5 & 1 \\
5 & 3 \\
5 & 8 \\
5 & 10 \\
6 & 5 \\
6 & 10 \\
7 & 5 \\
7 & 1 \\
7 & 1\end{array}$ & 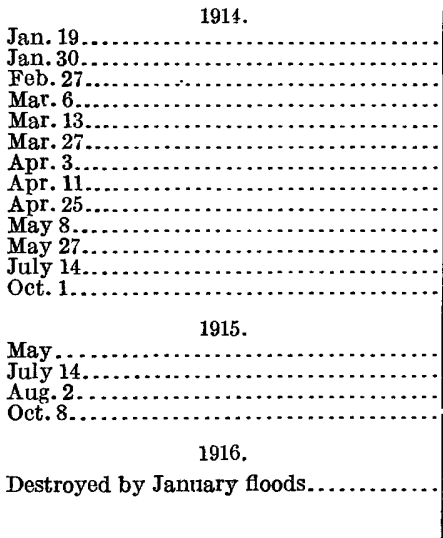 & $\begin{array}{rr}\text { Ft. } & \text { in. } \\
6 & 7 \\
5 & 4 \\
4 & 9 \\
5 & 0 \\
5 & 1 \\
4 & 7 \\
4 & 10 \\
4 & 9 \\
5 & 0 \\
5 & 2 \\
5 & 2 \\
5 & 4 \\
7 & 0 \\
& \end{array}$ \\
\hline
\end{tabular}


Records of water levels in wells in San Diego County, California-Continued.

H5. F. M. Judson, SW. $\frac{1}{4}$ sec. 35, T. 12 S., R. 1 W., San Pasqual.

[Dug well, 11.0 feet deep, 3 by 3 feet in cross section. Bench mark: Tack in top of 2 by 3 inch curb post at southwest corner, 4 inches above surface, 419.44 feet above sea level. Water-Supply Paper 446, P1. XLI.]

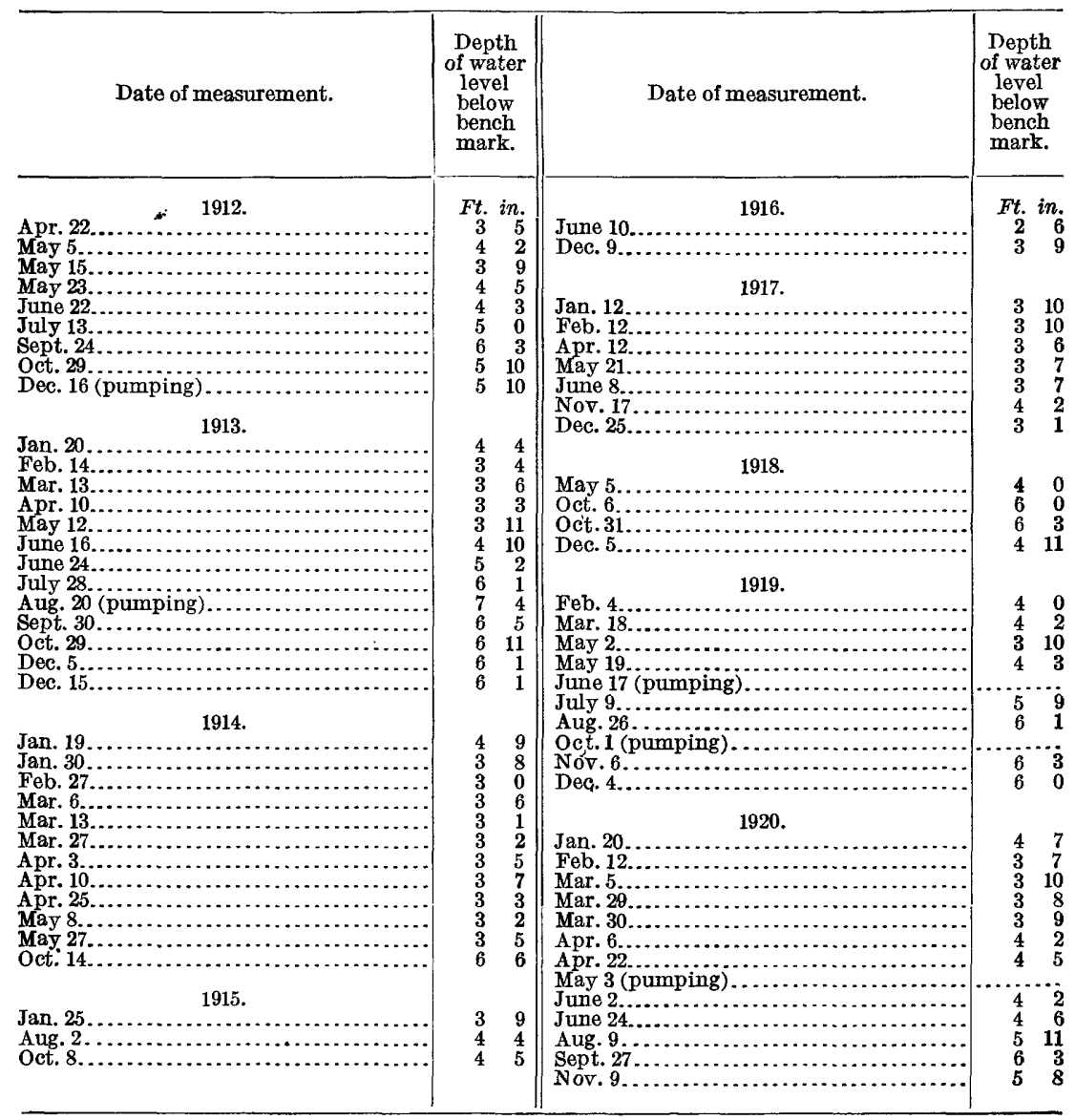




\section{Records of water levels in wells in San Diego County, California-Continued.}

\section{H31. H. S. Meyers, NE. $\frac{1}{4}$ SE. $\frac{1}{4}$ sec. 33, T. 12 S., R. 1 W., San Pasqual.}

[Dug well, 4 by 4 feet in cross section, 7 feet deep, not used. Bench mark: Tack in top of 2 by 4 inch post at northwest corner of curb, 3 feet above surface, 384.97 feet above sea level. Water-Supply Paper 446, Table 31, p. 130, and Pl. XLI.]

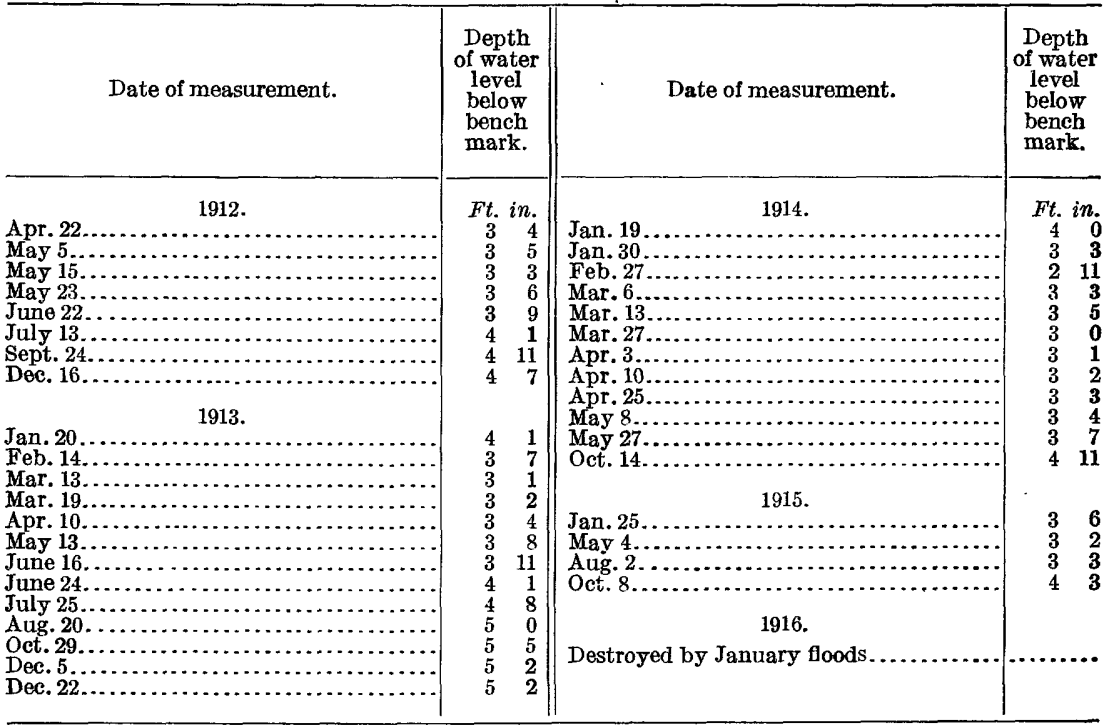

H31a. Well in NW. $\frac{1}{4}$ SW. $\frac{1}{4}$ sec. 33, T. 12 S., R. 1 W., one-fourth mile west of San Pasqual Creamery.

[Curbed well; method of lift, wind. Bench mark: Nail in top of 4 by 4 inch timber on north side of curb under cover, 2 inches above surface, 379.16 feet above sea level. Companion well for Nos. H31 and $\mathbf{H 1}$, Water-Supply Paper 446, Table 31, p. 130.]

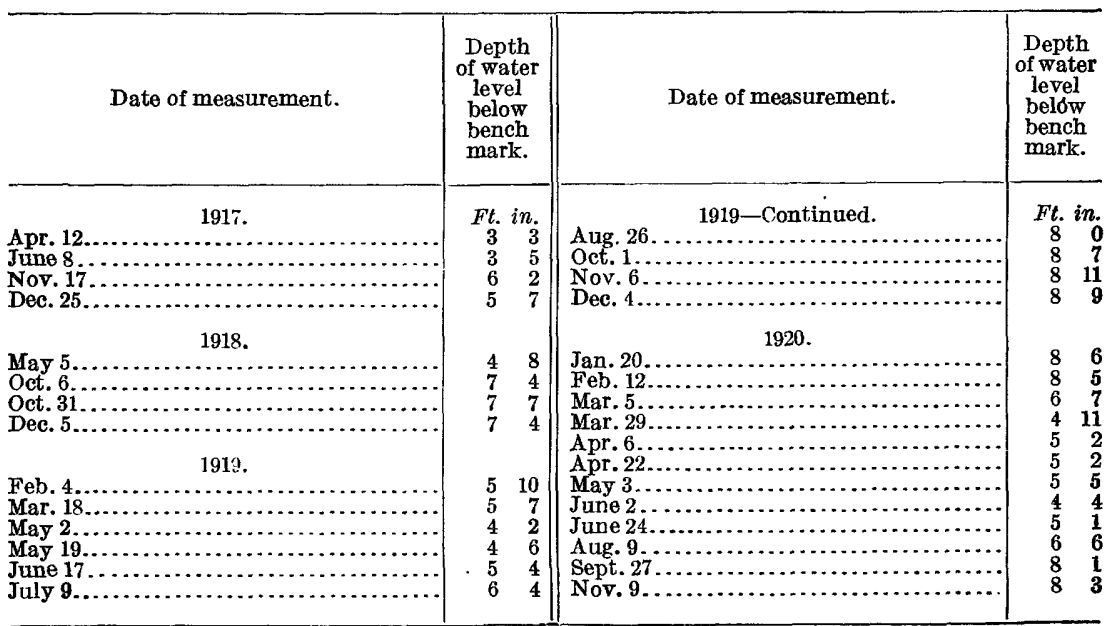


Records of water levels in wells in San Diego County, California-Continwed.

H34a. San Diego County highway bridge over Santa Ysabel Creek in NE. $\frac{1}{4}$ NW. $\frac{1}{4}$ sec. 35, T. 12 S., R. 1 W., San Pasqual.

[Bench mark: Nail at $V$ notch in upstream side of pile at northeast corner of bridge, 426.27 feet above sea level. Companion for well No. H34, Water-Supply Paper 446, Table 30, p. 126.]

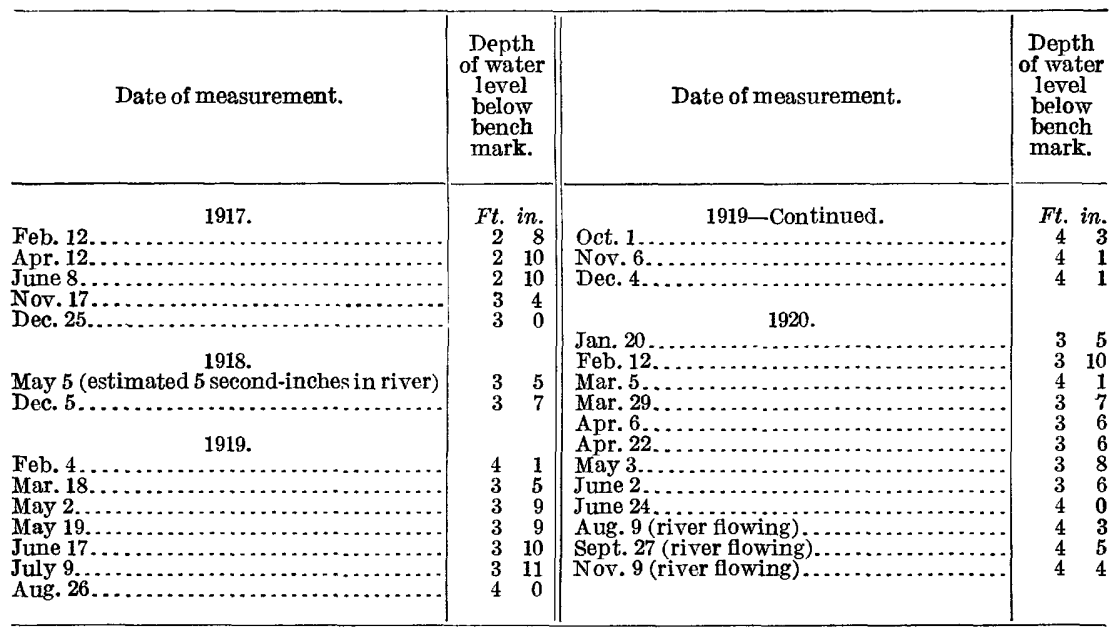

H37. H. A. Miles, Valle de Pamo land grant, Ramona.

[Dug well, 32 feet deep, 5 feet in diameter. Bench mark: Top of concrete curb, at southwest side, 0.5 foot above surface, 1,438.50 feet above sea level. Water-Supply Paper 446, Table 30, p. 126, and P1. XLVII.]

\begin{tabular}{|c|c|c|c|}
\hline Date of measurement. & $\begin{array}{l}\text { Depth } \\
\text { of water } \\
\text { level } \\
\text { below } \\
\text { bench } \\
\text { mark. }\end{array}$ & Date of measurement. & $\begin{array}{l}\text { Depth } \\
\text { of water } \\
\text { level } \\
\text { below } \\
\text { bench } \\
\text { mark. }\end{array}$ \\
\hline 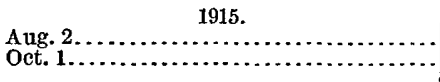 & $\begin{array}{lr}\text { Ft. } & \text { in. } \\
30 & 6 \\
27 & 9\end{array}$ & 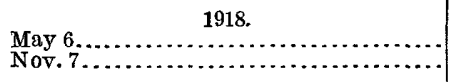 & $\begin{array}{lr}\text { Ft. } & \text { in. } \\
25 & 6 \\
26 & 7\end{array}$ \\
\hline $\begin{array}{l}\text { Jume } 10, \ldots \ldots \ldots \ldots \ldots \ldots \ldots \ldots \ldots \ldots \ldots \\
\text { Dec. } 9 . \ldots \ldots \ldots \ldots \ldots \ldots \ldots \ldots \ldots \ldots \ldots \ldots\end{array}$ & $\begin{array}{ll}24 & 4 \\
25 & 1\end{array}$ & May $19 \ldots \ldots \ldots \ldots \ldots$ & 2611 \\
\hline 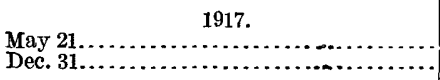 & $\begin{array}{ll}24 & 6 \\
26 & 9\end{array}$ & $\begin{array}{l}\text { Jan. } 31 \ldots \ldots \ldots \\
\text { Apr. } 28 \text { (pumping) } \\
\text { Sept. } 22 \ldots \ldots \ldots\end{array}$ & $\begin{array}{ll}28 & 4 \\
28 & 6\end{array}$ \\
\hline
\end{tabular}


Records of water levels in wells in San Diego County, California-Continued.

H38. Mark Kearney, Valle de Pamo land grant, Ramona.

[Dug well, 38 feet deep, 5 feet in diameter. Bench mark: Top of concrete curb, at southwest side, 2inches below surface, 1,424.56 feet above sea level. Water-Supply Paper 446, Table 30, p. 126, and P1. XLVII.]

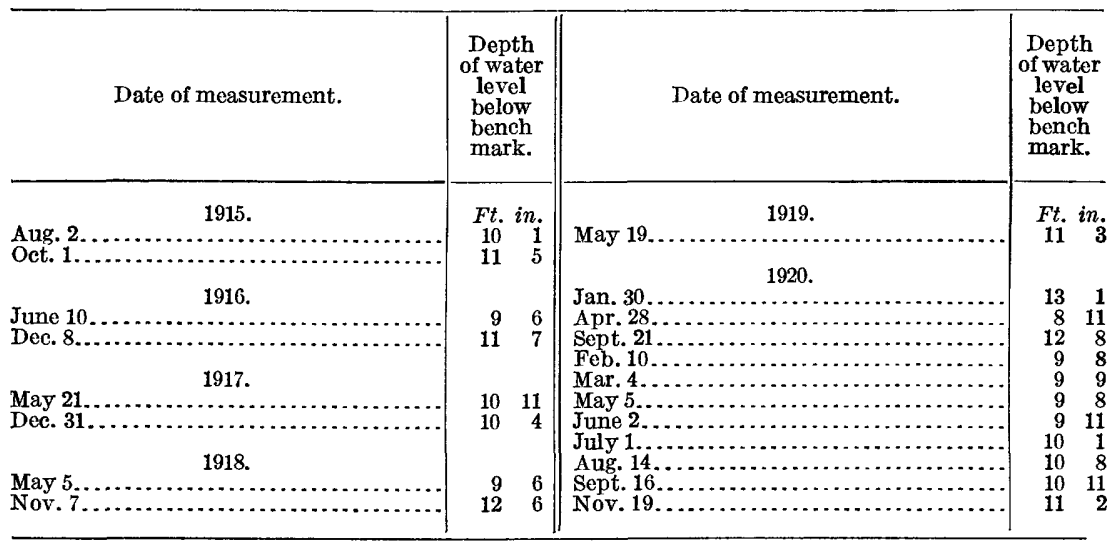

K31. L. H. Ieovich, Ex Mission San Diego, Mission Valley.

[Dug well, 24.3 feet deep, 6 feet in diameter. Bench mark: Top of concrete curb, at east side, 1 foot 8 inches above surface, 95.70 feet above sea level. Water-Supply Paper 446, Table 30, p. 126.]

\begin{tabular}{|c|c|c|c|}
\hline Date of measurement. & $\begin{array}{l}\text { Depth } \\
\text { of water } \\
\text { level } \\
\text { below } \\
\text { bench } \\
\text { mark. }\end{array}$ & Date of measurement. & $\begin{array}{l}\text { Depth } \\
\text { of water } \\
\text { level } \\
\text { below } \\
\text { bench } \\
\text { mark. }\end{array}$ \\
\hline 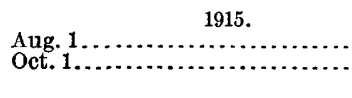 & $\begin{array}{rr}F t . & \text { in. } \\
16 & 9 \\
21 & 5\end{array}$ & $\begin{array}{l}\text { Apr. } 29 \ldots \ldots \ldots \\
\text { Aug. } 20 \ldots \ldots \ldots \ldots \ldots \ldots \ldots\end{array}$ & $\begin{array}{rr}\text { Ft. } & \text { in. } \\
7 & 4 \\
9 & 9 \\
10 & 3\end{array}$ \\
\hline
\end{tabular}

K33. G. S. Beach, Pueblo Lands of San Diego, Old Town.

[Dug well, 8 feet deep. Bench mark: Notch in 2 by 4 inch post at southwest corner of curb, 4 inches below suriace, 10.89 feet above sea level. Water-Supply Paper 446, Table 30, p. 126.]

\begin{tabular}{|c|c|c|c|}
\hline Date of measurement. & $\begin{array}{l}\text { Depth } \\
\text { of water } \\
\text { level } \\
\text { below } \\
\text { bench } \\
\text { mark. }\end{array}$ & Date of measurement. & $\begin{array}{l}\text { Depth } \\
\text { of water } \\
\text { level } \\
\text { below } \\
\text { bench } \\
\text { mark. }\end{array}$ \\
\hline 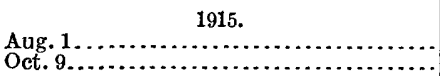 & $\begin{array}{rr}\text { Ft. } & \text { in. } \\
6 & 2 \\
6 & 6\end{array}$ & 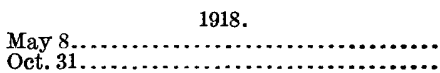 & $\begin{array}{rr}\text { Ft. in. } \\
3 & 11 \\
6 & 0\end{array}$ \\
\hline \begin{tabular}{c}
\multicolumn{1}{c}{1916.} \\
June $15 \ldots \ldots \ldots \ldots \ldots \ldots \ldots \ldots \ldots \ldots \ldots$
\end{tabular} & & 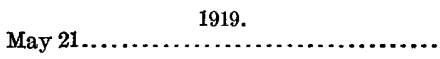 & \\
\hline $\begin{array}{c}1917 . \\
\text { May } 25 \ldots \ldots \ldots \ldots \ldots \ldots \ldots \ldots \ldots \ldots \ldots \ldots \ldots \ldots \ldots \ldots\end{array}$ & 211 & 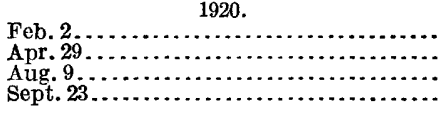 & $\begin{array}{rr}6 & 2 \\
4 & 0 \\
5 & 10 \\
6 & 2\end{array}$ \\
\hline
\end{tabular}


Records of water levels in wells in San Diego County, California-Continued.

K84a. George W. Johnson, Mission Valley, near county poor farm.

[Drilled well, 77 feet deep, 8-inch casing, sunk in A pril, 1916. Bench mark: Top of casing at surface. Companion well to K84. Water-Supply Paper 446, Table 30, p. 126.]

\begin{tabular}{|c|c|c|c|}
\hline Date of measurement. & $\begin{array}{l}\text { Depth } \\
\text { of water } \\
\text { level } \\
\text { below } \\
\text { bench } \\
\text { mark. }\end{array}$ & Date of measurement. & $\begin{array}{l}\text { Depth } \\
\text { of water } \\
\text { level } \\
\text { below } \\
\text { bench } \\
\text { mark. }\end{array}$ \\
\hline 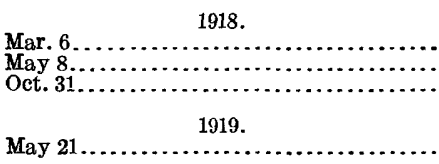 & $\begin{array}{rr}\text { Ft. } & \text { in. } \\
5 & 11 \\
14 & 8 \\
16 & 11 \\
& \\
16 & 7\end{array}$ & 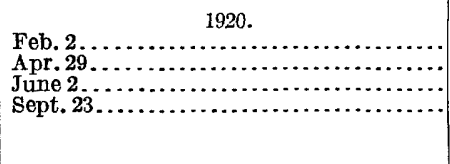 & $\begin{array}{rr}F t . & \text { in } \\
7 & 6 \\
16 & 4 \\
17 & 2 \\
18 & 0\end{array}$ \\
\hline
\end{tabular}

L5. G. E. Philbrook, El Cajon land grant, Lakeside.

[Dug well, 7 feet in diameter. Bench mark: Tack in top of wood curb on west side, 1 foot 5 inchesabove surface, 413.40 feet above sea level. Water-Supply Paper 446, Table 30, p. 127.]

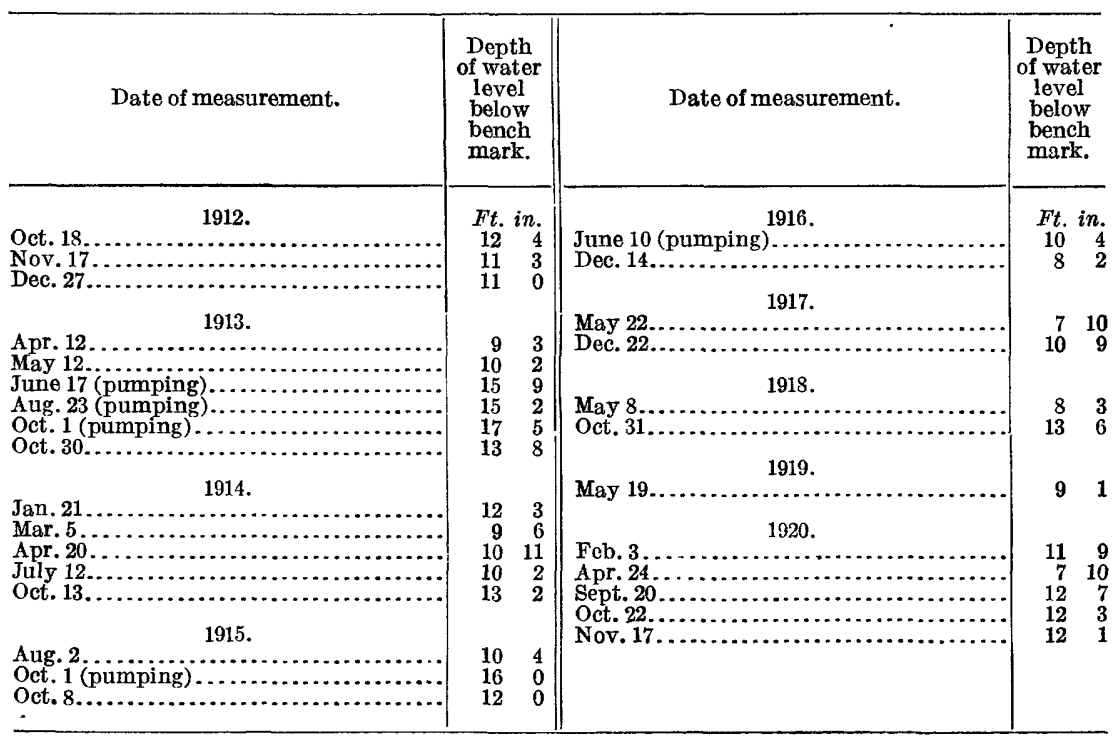


Records of water levels in wells in San Diego County, California-Continued.

L7a. Cuyamaca Water Co., El Cajon land grant, Lakeside.

[Dug well. Bench mark: Three notches in top of curb arc, on east side, 3 feet below surface, 435.25 feet above sea level. Prior to October, 1914, measurements were made from top of curb cover, about 1 foot 1 inch higher than bench nuark. Water-Supply Paper 446, Table 31, p. 130, and Pl. XL.]

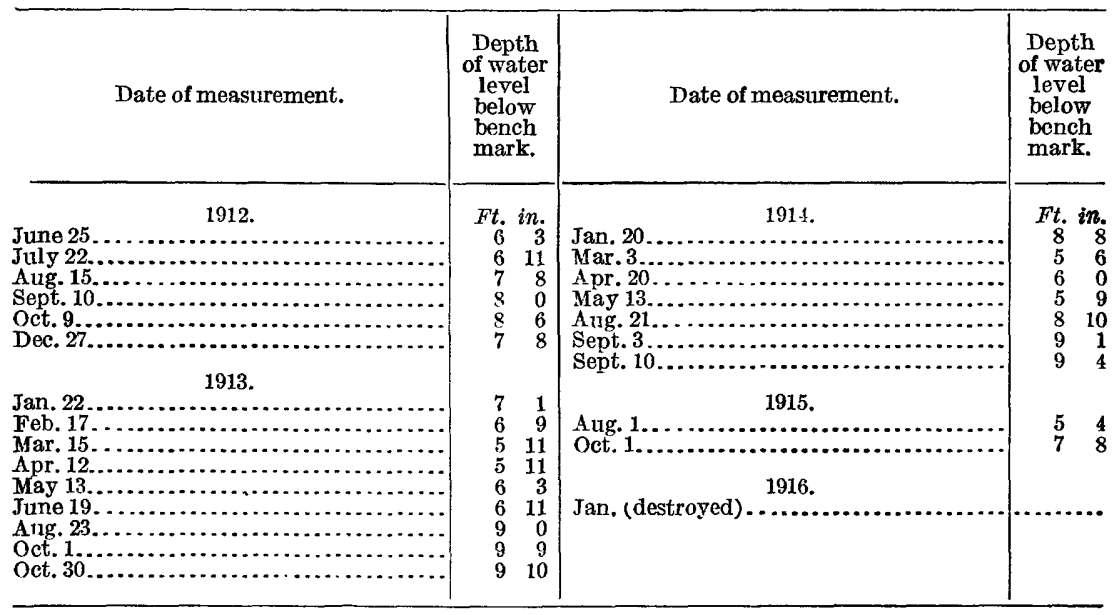

L7e. Cuyamaca Water Co., El Cajon land grant, Lakeside.

[Drilled well. Bench mark: Top of casing 1 foot above surface, 436.57 feet above sea level. Companion well to L7a. Water-Supply Paper 446, Table 30, p. 127.]

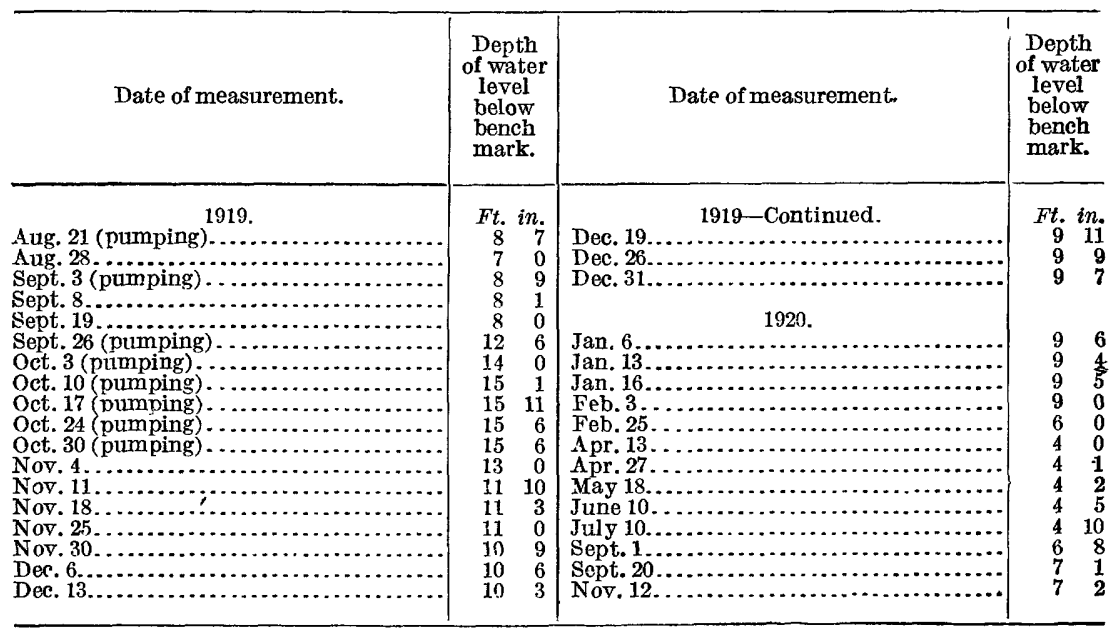


Records of water levels in wells in San Diego County, California-Continued.

L63a. Sumner ranch, El Cajon land grant, Foster.

[Driven well, 2 inches in diameter, equipped with well point. Installed by Curamaca Water Co. for observing depth of water plane. Bench mark: Top of casing 3.5 feet above surface, 432.85 feet above sea level. Companion well to L63. Water-Supply Paper 446, Table 30, p. 127.]

\begin{tabular}{|c|c|c|c|}
\hline Date of measurement. & $\begin{array}{l}\text { Depth } \\
\text { of water } \\
\text { level } \\
\text { below } \\
\text { bench } \\
\text { mark. }\end{array}$ & Date of measurement. & $\begin{array}{l}\text { Depth } \\
\text { of water } \\
\text { level } \\
\text { below } \\
\text { bench } \\
\text { mark. }\end{array}$ \\
\hline 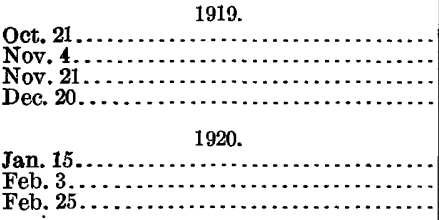 & $\begin{array}{rr}\text { Ft. } & \text { in } \\
14 & 11 \\
14 & 9 \\
14 & 4 \\
14 & 0 \\
& \\
13 & 11 \\
13 & 11 \\
13 & 6\end{array}$ & 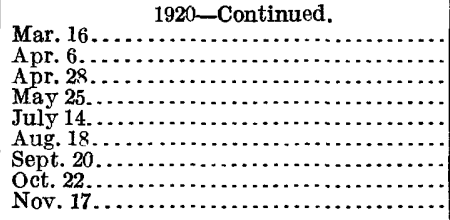 & $\begin{array}{rr}\text { Ft. } & \text { in. } \\
13 & 3 \\
4 & 9 \\
5 & 10 \\
7 & 8 \\
9 & 2 \\
10 & 9 \\
11 & 0 \\
11 & 4 \\
11 & 7\end{array}$ \\
\hline
\end{tabular}

L65. G. E. Philbrook, El Cajon land grant, Lakeside.

[Dug well, 7 feet in diameter. Bench mark: Top of curb on east side, 2 inches above surface, 412.20 feet above sea level. Water-Supply Paper 446, Table 31, p. 130, and Pl. XL ]

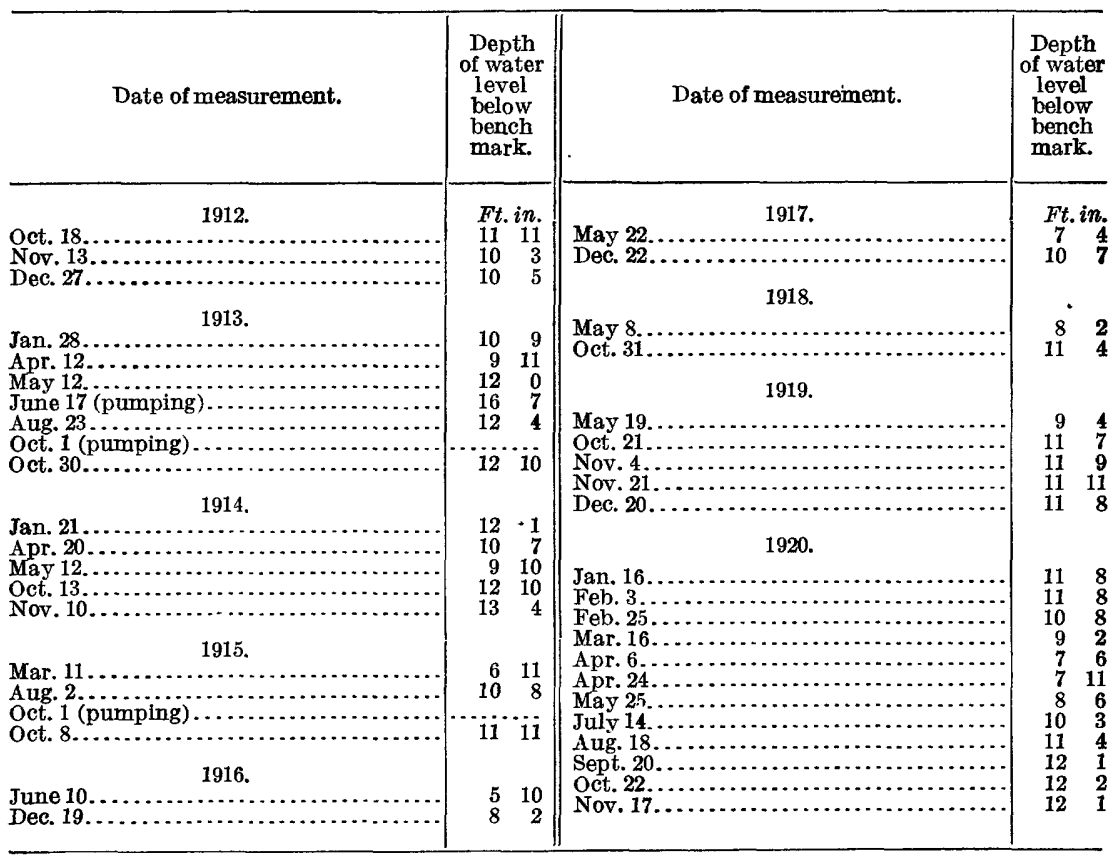


Records of water levels in wells in San Diego County, California-Continued.

L65a. Barttell ranch, El Cajon land grant, Lakeside.

[Driven well, 2 inches in diameter, equipped with well point. Installed by Cuyamaca Water Co. for observing depth of water plane. Bench mark: Top of casing, 3 feet 7 inches above surface. Altitude of bench mark, 408.51 feet above sealevel. Companion well to L65. Water-Supply Paper 446, Table 31, p. 130.]

\begin{tabular}{|c|c|c|c|}
\hline Date of measurement. & $\begin{array}{c}\text { Depth } \\
\text { of water } \\
\text { level } \\
\text { below } \\
\text { bench } \\
\text { mark. }\end{array}$ & Date of measurement. & $\begin{array}{l}\text { Depth } \\
\text { of water } \\
\text { level } \\
\text { below } \\
\text { bench } \\
\text { mark. }\end{array}$ \\
\hline 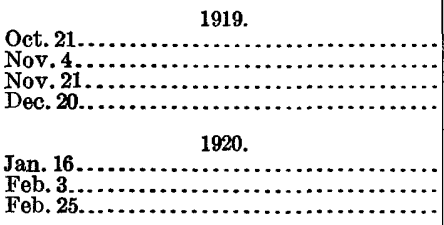 & $\begin{array}{cc}\text { Ft. } & \text { in. } \\
8 & 5 \\
8 & 2 \\
8 & 3 \\
8 & 1 \\
& \\
8 & 0 \\
8 & 0 \\
6 & 9\end{array}$ & 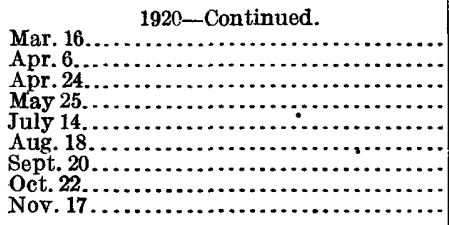 & $\begin{array}{rr}\text { Ft. } & \text { in. } \\
5 & 6 \\
3 & 10 \\
4 & 5 \\
5 & 0 \\
6 & 11 \\
7 & 11 \\
8 & 5 \\
8 & 7 \\
8 & 6\end{array}$ \\
\hline
\end{tabular}

L70. U. S. Geological Survey, El Cajon land grant, Lakeside.

[River gage. Zero of gage, 5 feet below surface; 405.00 feet above sea level. Water-Supply Paper 446, Table 31 , p. 130, and Pl. XL.]

\begin{tabular}{|c|c|c|c|}
\hline Date of measurement. & $\begin{array}{l}\text { Gage } \\
\text { readings } \\
\text { at water } \\
\text { plane. }\end{array}$ & Date of measurement. & $\begin{array}{l}\text { Gage } \\
\text { readings } \\
\text { at water } \\
\text { plane. }\end{array}$ \\
\hline 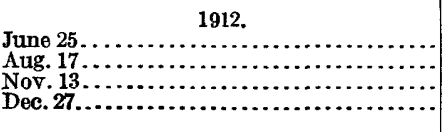 & $\begin{array}{rr}F t . & \text { in. } \\
2 & 8 \\
1 & 8 \\
1 & 3 \\
1 & 8\end{array}$ & 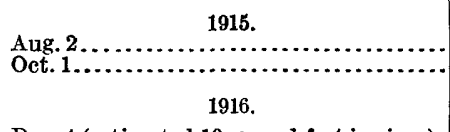 & $\begin{array}{rr}\text { Ft. in. } \\
1 & 10 \\
& 6\end{array}$ \\
\hline 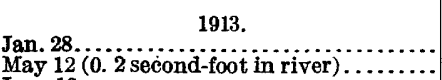 & $\begin{array}{ll}2 & 4 \\
2 & 5\end{array}$ & $\begin{array}{c}\text { Dec. } 4 \text { (estimated } 10 \text { second-feet in river). } \\
1917 .\end{array}$ & 46 \\
\hline 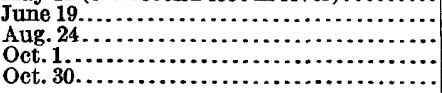 & $\begin{array}{r}10 \\
5 \\
0 \\
-5\end{array}$ & $\begin{array}{c}\text { May } 23 \text { (estimated } 20 \text { second-feet in river). } \\
\text { Dec. } 22 \ldots \ldots \ldots \ldots \ldots \ldots \ldots \ldots \ldots \ldots \ldots \\
1918 .\end{array}$ & $\begin{array}{rr}5 & 0 \\
1 & 10\end{array}$ \\
\hline 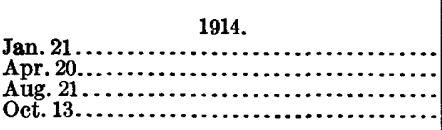 & $\begin{array}{r}5 \\
2 \\
1 \\
0 \\
-5\end{array}$ & $\begin{array}{l}\text { May } 8 \text { (estimated } 0.2 \text { second-foot in river) } \\
\text { Oet. } 31 \ldots \ldots \ldots \ldots\end{array}$ & $\begin{array}{r}40 \\
-1\end{array}$ \\
\hline
\end{tabular}

L70a. H. Thum, El Cajon land grant, Lakeside.

[Driven well, 2-inch pipe, equipped with well point. Installed by Cuyamaca Water Co. for observing depth of water plane. Bench mark: Top of casing, 3.5 feet above surface, 414.85 feet above sea level. Companion well to L70. Water-Supply Paper 446, Table 31, p. 130.]

\begin{tabular}{|c|c|c|c|}
\hline Date of measurement. & $\begin{array}{l}\text { Depth } \\
\text { of water } \\
\text { level } \\
\text { below } \\
\text { bench } \\
\text { mark. }\end{array}$ & Date of measurement. & $\begin{array}{l}\text { Depth } \\
\text { of water } \\
\text { level } \\
\text { below } \\
\text { bench } \\
\text { mark. }\end{array}$ \\
\hline 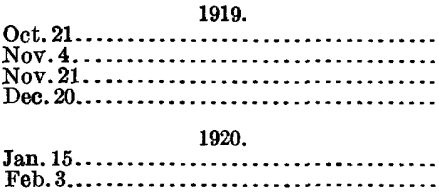 & $\begin{array}{rr}\text { Ft. } & \text { in. } \\
12 & 2 \\
12 & 2 \\
12 & 2 \\
12 & 2 \\
& \\
12 & 3 \\
12 & 3\end{array}$ & 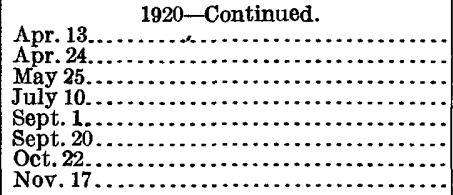 & $\begin{array}{rr}\text { Ft. } & \text { in. } \\
6 & 6 \\
6 & 6 \\
7 & 0 \\
10 & 2 \\
11 & 11 \\
12 & 2 \\
12 & 4 \\
12 & 3\end{array}$ \\
\hline
\end{tabular}


Records of water levels in wells in San Diego County, California-Continued.

L75. El Monte ranch, El Cajon land grant (Cape Horn), Lakeside.

[Drilled well, 20 feet deep, 6 inches in diameter. Bench mark: Top of casing at surface. Water-Supply Paper 446, Table 31, p. 130, and Pl. XL.]

\begin{tabular}{|c|c|c|c|}
\hline Date of measurement. & $\begin{array}{c}\text { Depth } \\
\text { of water } \\
\text { level } \\
\text { below } \\
\text { bench } \\
\text { mark. }\end{array}$ & Date of measurement. & $\begin{array}{l}\text { Depth } \\
\text { of water } \\
\text { level } \\
\text { below } \\
\text { bench } \\
\text { mark. }\end{array}$ \\
\hline 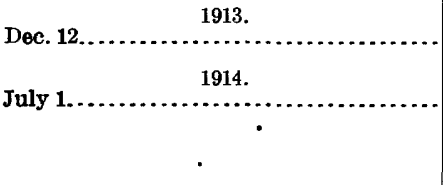 & $\begin{array}{rr}F t . & \text { in. } \\
19 & 3 \\
9 & 3\end{array}$ & 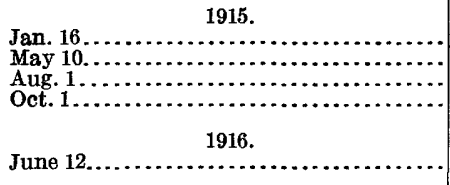 & $\begin{array}{rr}\text { Ft. } & \text { in. } \\
18 & 5 \\
6 & 3 \\
8 & 6 \\
12 & 0 \\
& \\
8 & 7\end{array}$ \\
\hline
\end{tabular}

L75a. Cuyamaca Water Co., El Cajon land grant (Cape Horn), Lakeside.

[Driven well, 3-inch pipe, equipped with well point. Installed by Cuyamaca Water Co. for observing depth of water plane. Bench mark: Top of casing, 4.5 feet above surface. Companion well to L75. Water-Supply Paper 446, Table 31, p. 130.]

\begin{tabular}{|c|c|c|c|}
\hline $\begin{array}{c}\text { Date of measurement. } \\
\text {. }\end{array}$ & $\begin{array}{l}\text { Depth } \\
\text { of water } \\
\text { level } \\
\text { below } \\
\text { bench } \\
\text { mark. }\end{array}$ & Date of measurement. & $\begin{array}{l}\text { Depth } \\
\text { of water } \\
\text { level } \\
\text { below } \\
\text { bench } \\
\text { mark. }\end{array}$ \\
\hline 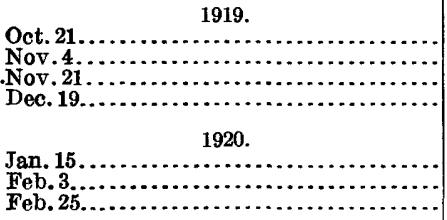 & $\begin{array}{rr}\text { Ft. } & \text { in. } \\
25 & 2 \\
25 & 6 \\
25 & 11 \\
22 & 11 \\
& \\
21 & 8 \\
20 & 5 \\
12 & 6\end{array}$ & 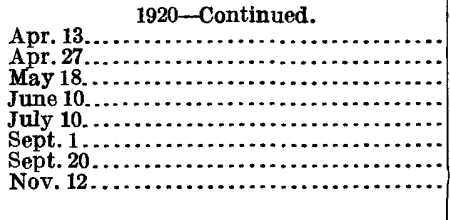 & $\begin{array}{rr}\text { Ft. } & \text { in. } \\
11 & 4 \\
11 & 4 \\
11 & 8 \\
13 & 5 \\
16 & 4 \\
20 & 9 \\
21 & 8 \\
24 & 5\end{array}$ \\
\hline
\end{tabular}

L78. Gay estate, El Cajon land grant, Lakeside.

[Drilled well, 52.8 feet deep, 12 inches in diameter. Bench mark: Top of casing, 10 inches above surface, 401.66 feet above sea level. Water-Supply Paper 446, Table 30, p. 127, and Pl. XLIII.]

\begin{tabular}{|c|c|c|c|}
\hline Date of measurement. & $\begin{array}{l}\text { Depth } \\
\text { of water } \\
\text { level } \\
\text { below } \\
\text { bench } \\
\text { mark. }\end{array}$ & Date of measurement. & $\begin{array}{l}\text { Depth } \\
\text { of water } \\
\text { level } \\
\text { below } \\
\text { bench } \\
\text { mark. }\end{array}$ \\
\hline 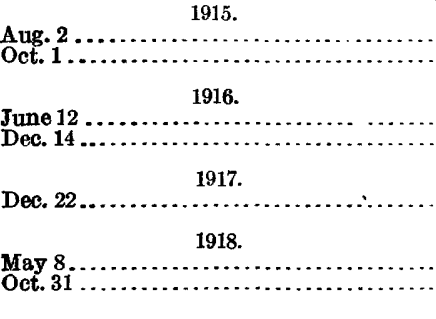 & $\begin{array}{rr}\text { Ft. in. } \\
10 & 1 \\
13 & 4 \\
& \\
6 & 2 \\
7 & 3 \\
& \\
10 & 0 \\
& \\
7 & 5 \\
11 & 0\end{array}$ & 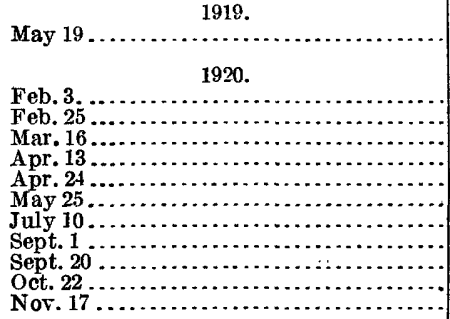 & $\begin{array}{rr}\text { Ft. } & \text { in. } \\
9 & 5 \\
& \\
11 & 1 \\
11 & 3 \\
10 & 7 \\
9 & 9 \\
9 & 8 \\
9 & 7 \\
10 & 6 \\
11 & 9 \\
12 & 1 \\
12 & 6 \\
12 & 6\end{array}$ \\
\hline
\end{tabular}


Records of water levels in wells in San Diego 'County, California-Continued.

L83. San Francisco Savings Union, El Cajon land grant, Santee.

[Drilled well, 68 feet deep, 10 inches in diameter. Bench mark: Top of easing, 1.5 feet above surface, 364.48 feet above sea level. Water-Supply Paper 446, Table 30, p. 127, and Pl. XL.]

\begin{tabular}{|c|c|c|c|}
\hline Date of measurement. & $\begin{array}{c}\text { Depth } \\
\text { of water } \\
\text { level } \\
\text { below } \\
\text { bench } \\
\text { mark. }\end{array}$ & Date of measurement. & $\begin{array}{l}\text { Depth } \\
\text { of water } \\
\text { level } \\
\text { below } \\
\text { bench } \\
\text { mark. }\end{array}$ \\
\hline 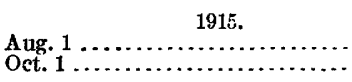 & $\begin{array}{rr}\text { Ft. } & \text { in. } \\
6 & 8 \\
8 & 6\end{array}$ & $\begin{array}{c}1916 . \\
\text { Destroyed by January floods... }\end{array}$ & $\begin{array}{r}\text { Ft. in. } \\
\text {.......... }\end{array}$ \\
\hline
\end{tabular}

L83a. Cuyamaca Water Co., El Cajon land grant, Riverview.

[Driven well, 2-inch pipe, equipped with well point. Installed by Cuyamaca Water Co. for observing depth of water plane. Bench mark: Top of pipe, 4 feet above surface, 370.81 feet above sea level. Chosen for a companion for well L83. Water-Supply Paper 446, Table 30, p. 127.J

\begin{tabular}{|c|c|c|c|}
\hline Date of measurement. & $\begin{array}{c}\text { Depth } \\
\text { of water } \\
\text { level } \\
\text { below } \\
\text { bench } \\
\text { mark. }\end{array}$ & Date of measurement. & $\begin{array}{l}\text { Depth } \\
\text { of water } \\
\text { level } \\
\text { below } \\
\text { bench } \\
\text { mark. }\end{array}$ \\
\hline 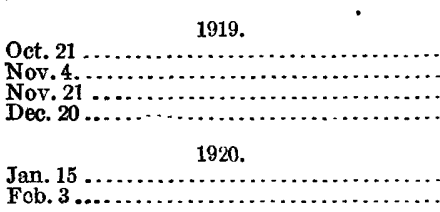 & $\begin{array}{rr}\text { Ft. } & \text { in. } \\
8 & 0 \\
7 & 11 \\
7 & 9 \\
7 & 5 \\
& \\
7 & 3 \\
7 & 3\end{array}$ & 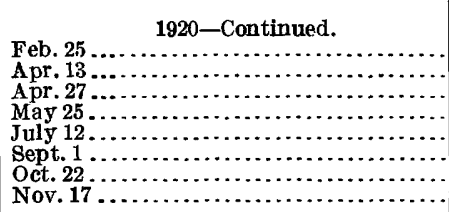 & $\begin{array}{rr}\text { Ft. } & \text { in. } \\
6 & 7 \\
6 & 5 \\
6 & 7 \\
6 & 8 \\
7 & 10 \\
8 & 10 \\
8 & 5 \\
8 & 2\end{array}$ \\
\hline
\end{tabular}

L85. William Thum, El Cajon land grant, Santee.

[Dug well, 22.8 feet deep, 10 feet in diameter. Bench mark: Top of curb on west side, at surface, 335.00 feet above sea level. Water-Supply Paper 446, Table 30, p. 127.]

\begin{tabular}{|c|c|c|c|}
\hline Date of measurement. & $\begin{array}{c}\text { Depth } \\
\text { of water } \\
\text { level } \\
\text { below } \\
\text { bench } \\
\text { mark. }\end{array}$ & Date of measurement. & $\begin{array}{l}\text { Depth } \\
\text { of water } \\
\text { level } \\
\text { below } \\
\text { bench } \\
\text { mark. }\end{array}$ \\
\hline 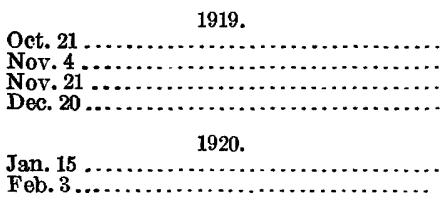 & $\begin{array}{lr}F t . & \text { in. } \\
12 & 5 \\
12 & 5 \\
12 & 8 \\
12 & 3 \\
& \\
12 & 2 \\
12 & 1\end{array}$ & 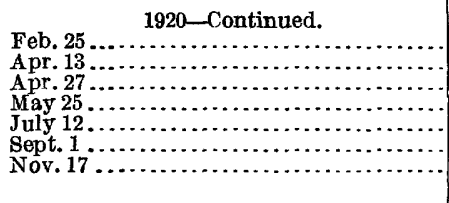 & $\begin{array}{rr}\text { Ft. } & \text { in. } \\
10 & 1 \\
8 & 7 \\
8 & 2 \\
8 & 3 \\
9 & 9 \\
10 & 9 \\
11 & 1\end{array}$ \\
\hline
\end{tabular}


Records of water levels in wells in San Diego County, California-Continued.

\section{L96. El Cajon land grant, El Cajon.}

[Dug well, 26 feet deep, 6 feet in diameter. Bench mark: Top of hexagonal wood curb on west side, 2 inches above surface, 441.80 feet above sea level. Water-Supply Paper 446, Table 31, p. 130, and Pl. XIVII.]

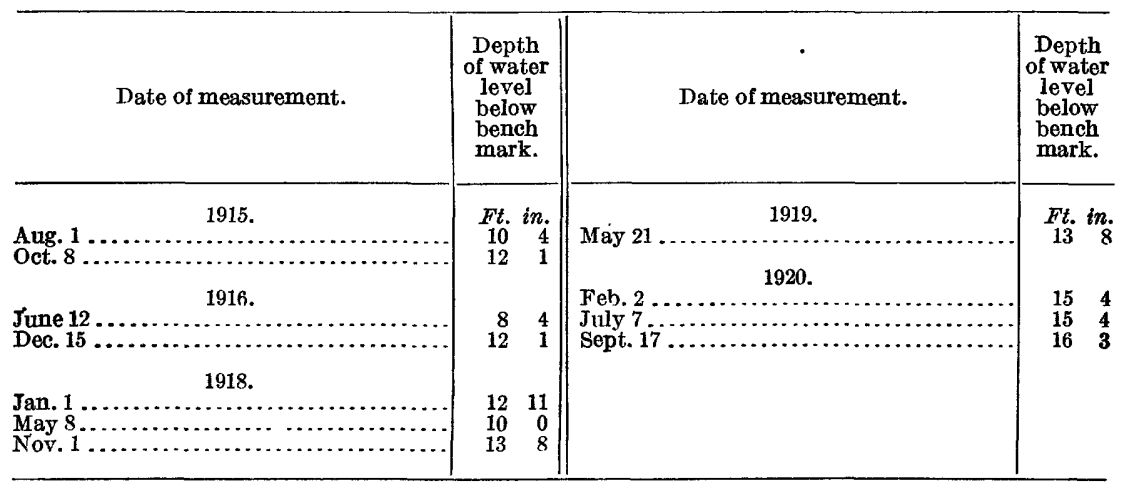

018. L. C. Kincaid, La Nacion land grant, Sunnyside.

[Dug well, 12 feet 8 inches deep, 8 feet in diameter. Bench mark: Top of concrete curb on northwest side, at surface, 89.48 feet above sea level. Water-Supply Paper 446, Table 30, p. 127, and PI. XXXVII.]

\begin{tabular}{|c|c|c|c|}
\hline Date of measurement. & $\begin{array}{l}\text { Depth } \\
\text { of water } \\
\text { level } \\
\text { below } \\
\text { bench } \\
\text { mark. }\end{array}$ & Date of measurement. & $\begin{array}{l}\text { Depth } \\
\text { of water } \\
\text { level } \\
\text { below } \\
\text { bench } \\
\text { mark. }\end{array}$ \\
\hline 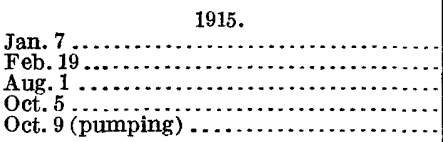 & $\begin{array}{rr}\text { Ft. } & \text { in. } \\
8 & 3 \\
5 & 4 \\
6 & 11 \\
7 & 10 \\
11 & 3\end{array}$ & $\begin{array}{c}1916 . \\
\text { January (destroyed by floods) . . . . . . . }\end{array}$ & Ft. in. \\
\hline
\end{tabular}

O18a. L. C. Kincaid, La Nacion land grant, Sunnyside.

[Drilled well. Bench mark: Top of casing, 2 feet below surface. Lift, gasoline engine and centrifuga] pump. Companion well for O18. Water-Supply Paper 446,Table 30, p.127. Well 200 feet northeast of 018, which was destroved by floods of January, 1916.]

\begin{tabular}{|c|c|c|c|}
\hline Date of measurement. & $\begin{array}{l}\text { Depth } \\
\text { of water } \\
\text { level } \\
\text { below } \\
\text { bench } \\
\text { mark. }\end{array}$ & Date of measurement. & $\begin{array}{l}\text { Depth } \\
\text { of water } \\
\text { level } \\
\text { below } \\
\text { bench } \\
\text { mark. }\end{array}$ \\
\hline \begin{tabular}{c}
\multicolumn{2}{c}{1920.} \\
Apr. $29 \ldots \ldots \ldots \ldots \ldots \ldots \ldots$
\end{tabular} & $\underset{11}{\text { Ft. in. }}$ & $\begin{array}{r}1920-\text { Continued. } \\
\text { Oct. } 24 \ldots \ldots \ldots \ldots \ldots \ldots \ldots\end{array}$ & Ft. in. \\
\hline
\end{tabular}


Records of water levels in wells in San Diego County, California-Continued.

O29. F. M. Winship, La Nacion land grant, Chula Vista.

[Dug well 57.0 feet deep, 4 by 4 feet in cross section. Lift, windmill; use, domestic purposes. Bench mark: Top of wood curb on north side, 9 inches above surface, 62.14 feet above sea level. Water-Supply Paper 446, Table 30, p. 128.]

\begin{tabular}{|c|c|c|c|}
\hline Date of measurement. & $\begin{array}{c}\text { Depth } \\
\text { of water } \\
\text { level } \\
\text { below } \\
\text { bench } \\
\text { mark. }\end{array}$ & Date of measurement. & $\begin{array}{l}\text { Depth } \\
\text { of water } \\
\text { level } \\
\text { below } \\
\text { bench } \\
\text { mark. }\end{array}$ \\
\hline 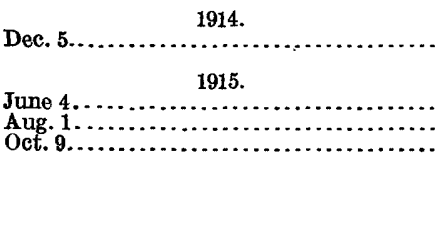 & $\begin{array}{rr}\text { Ft. } & \text { in. } \\
51 & 3 \\
& \\
50 & 8 \\
50 & 8 \\
51 & 2\end{array}$ & 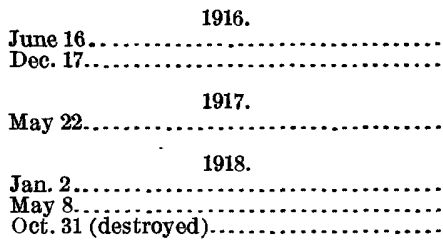 & $\begin{array}{rr}\text { Ft. } & \text { in } \\
49 & 10 \\
50 & 9 \\
& \\
49 & 5 \\
& \\
49 & 5 \\
49 & 7 \\
\end{array}$ \\
\hline
\end{tabular}

O39. W. F. Clark, NW. $\frac{1}{4}$ sec. 23 , T. 18 S., R. 2 W., Otay.

[Dug and drilled well, 90 feet deep. Bench mark: Top of concrete curb on east side, 1 foot above surface, 56.30 feet above sea level. Water-Supply Paper 446, Table 30, p. 128, and PI. XLV.]

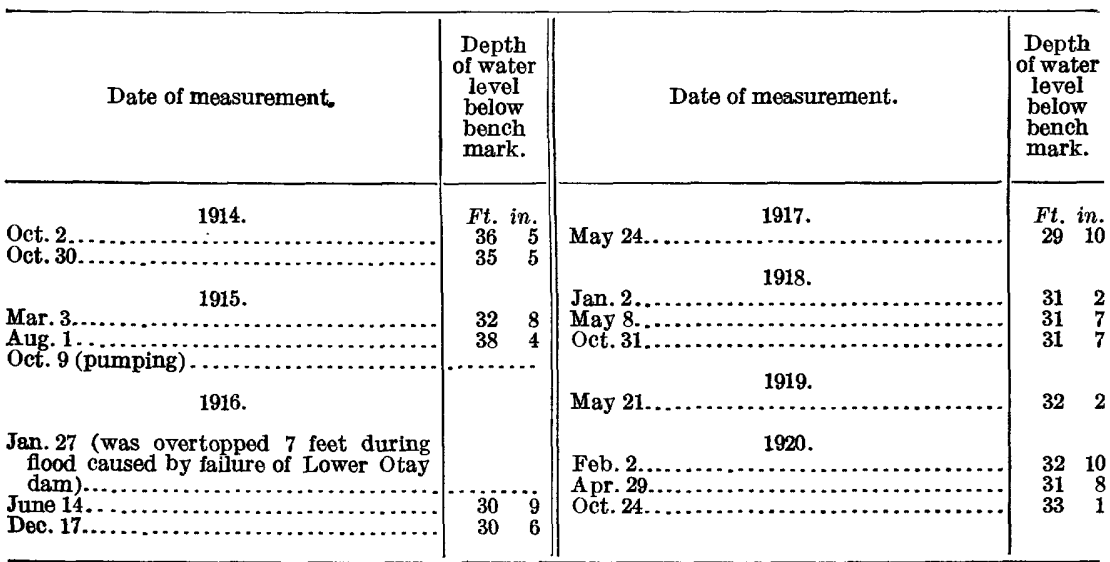

O83. San Diego Construction Co., La Nacion land grant, Chula Vista.

[Dug well, 63.0 feet deep. Bench mark: Top of timber on south side of wood curb, at surface, 57.60 feet above sea level. Water-Supply Paper 446, Table 30, p. 128.]

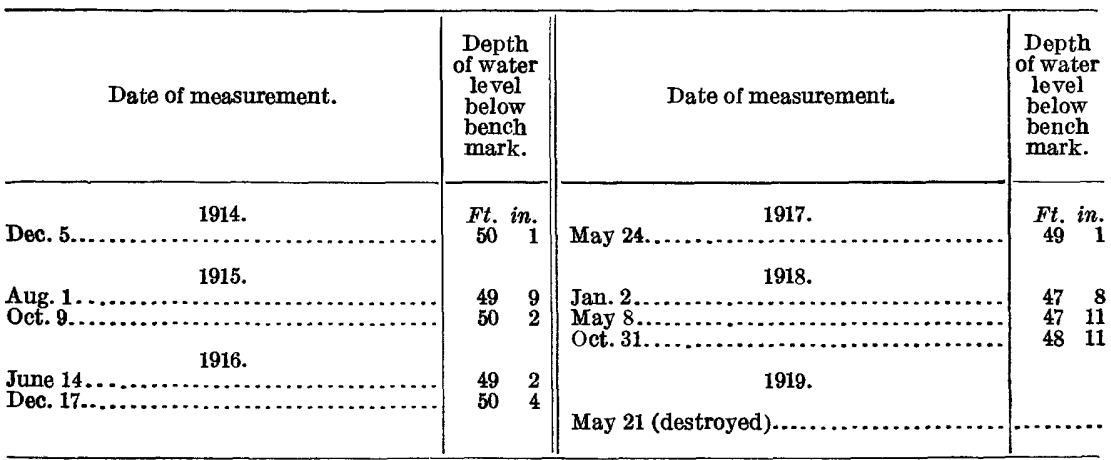


Records of water levels in wells in San Diego County, California-Continued.

O89a. J. Rhodeos, NE. $\frac{1}{1}$ sec. 24, T. 18 S., R. 2 W., Otay.

[Dug well, 33 feet deep, 3 by 3 feet in cross section. Lift, wind. Used for domestic purposes and irrigation. Bench mark: Top of 2-inch wood curb, 1 foot 5 inches above surface. Companion well to Nos. O88 and O89. Water-Supply Paper 446, Table 30, p. 128.]

\begin{tabular}{|c|c|c|c|}
\hline Date of measurement. & $\begin{array}{l}\text { Depth } \\
\text { of water } \\
\text { level } \\
\text { below } \\
\text { bench } \\
\text { mark. }\end{array}$ & Date of measurement. & $\begin{array}{l}\text { Depth } \\
\text { of water } \\
\text { level } \\
\text { below } \\
\text { bench } \\
\text { mark. }\end{array}$ \\
\hline 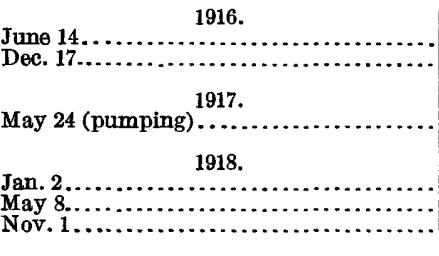 & $\begin{array}{rr}F t . & \text { in. } \\
20 & 2 \\
19 & 10 \\
& \end{array}$ & 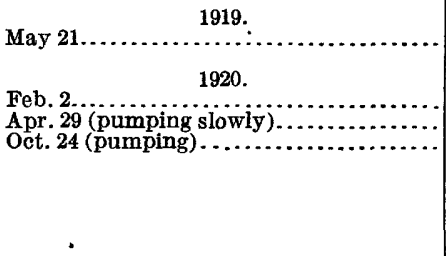 & $\begin{array}{rr}F l . & \text { in. } \\
22 & 4 \\
& \\
22 & 10 \\
22 & 8 \\
30 & 4\end{array}$ \\
\hline
\end{tabular}

O104. Alfonso Fredericks, SW. $\frac{1}{1}$ sec. 28, T. 18 S., R. 2 W., Nestor.

[Drilled well, 70 feet 6 inches deep, 12 inches in diameter, not used. Bench mark: Top of casing between timbers, 1 foot above surface, 53.30 feet above sea level. Water-Supply Paper 446, Table 30, p. 129, and Pl. XLV.]

\begin{tabular}{|c|c|c|c|}
\hline Date of measurement. & $\begin{array}{l}\text { Depth } \\
\text { of water } \\
\text { level } \\
\text { below } \\
\text { bench } \\
\text { mark. }\end{array}$ & Date of measurement. & $\begin{array}{l}\text { Depth } \\
\text { of water } \\
\text { level } \\
\text { below } \\
\text { bench } \\
\text { mark. }\end{array}$ \\
\hline 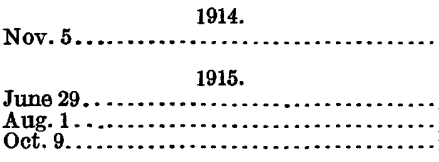 & $\begin{array}{rr}\text { Ft. } & \text { in. } \\
49 & 8 \\
& \\
47 & 3 \\
47 & 6 \\
47 & 8\end{array}$ & 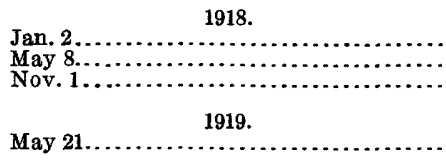 & $\begin{array}{rr}\text { Ft. } & \text { in. } \\
46 & 0 \\
45 & 8 \\
47 & 2 \\
& \\
47 & 4\end{array}$ \\
\hline 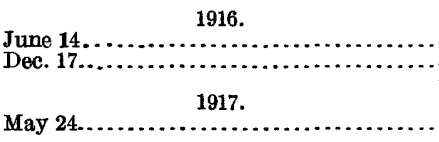 & $\begin{array}{rr}45 & 1 \\
45 & 8 \\
& \\
44 & 10\end{array}$ & 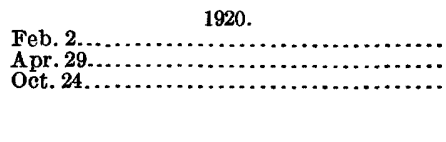 & $\begin{array}{rr}48 & 1 \\
47 & 11 \\
49 & 8\end{array}$ \\
\hline
\end{tabular}

O118. Well in SW. $\frac{1}{4}$ sec. 33, T. 18 S., R. 2 W., Tia Juana Valley.

[Driven well, 16 feet 6 inches deep, $1 \frac{1}{2}$-inch pipe; not used. Bench mark: Top of flange at head of $1 \frac{1}{2}$-inch pipe, 1 foot 10 inches above surface, 26.80 feet above sea level. Water-Supply Paper 446, Table 30, p. 129, and Pl. XXXVI.]

\begin{tabular}{|c|c|c|c|}
\hline Date of measurement. & $\begin{array}{l}\text { Depth } \\
\text { of water } \\
\text { J evel } \\
\text { below } \\
\text { bench } \\
\text { mark. }\end{array}$ & Date of measurement. & $\begin{array}{l}\text { Depth } \\
\text { of water } \\
\text { level } \\
\text { below } \\
\text { bench } \\
\text { mark. }\end{array}$ \\
\hline Oct. $30 \ldots \ldots \ldots \ldots$ & ${ }_{17}{ }_{i n}{ }_{2}$ & May $24 \ldots \ldots \ldots \ldots$ & Ft. in. \\
\hline 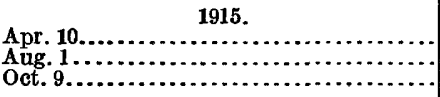 & $\begin{array}{rr}7 & 2 \\
9 & 4 \\
10 & 6\end{array}$ & 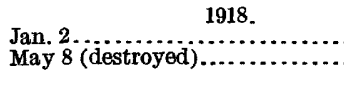 & $\begin{array}{rr}9 & 4 \\
\cdots & 9\end{array}$ \\
\hline 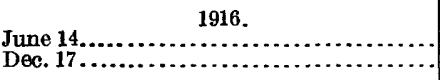 & $\begin{array}{rr}6 & 3 \\
6 & 11\end{array}$ & & \\
\hline
\end{tabular}


Records of water levels in wells in San Diego County, California-Continued.

O118a. Well in SW. $\frac{1}{4}$ sec. 33, T. 18 S., R. 2 W., Tia Juana Valley.

[Dug well. Lift, gasoline engine and centrifugal pump. Bench mark: Top of 1-inch cover, at surface. Companion well to 0118. Water-Supply Paper 446, Table 30, p. 129.]

\begin{tabular}{|c|c|c|c|}
\hline Date of measurement. & $\begin{array}{l}\text { Depth } \\
\text { of water } \\
\text { level } \\
\text { below } \\
\text { bench } \\
\text { mark. }\end{array}$ & Date of measurement. & $\begin{array}{l}\text { Depth } \\
\text { of water } \\
\text { level } \\
\text { below } \\
\text { bench } \\
\text { mark. }\end{array}$ \\
\hline $\begin{array}{c}1918 . \\
\text { May } 8 \ldots \ldots \ldots \ldots \ldots \ldots \ldots \ldots \ldots \\
\text { Nov. } 1 \ldots \ldots \ldots \ldots \ldots \ldots \ldots \ldots \\
\text { May } 21 \text { (pumping) } 1919 . \ldots \ldots \ldots \ldots\end{array}$ & $\begin{array}{rr}F t . & \text { in } \\
7 & 7 \\
9 & 0\end{array}$ & 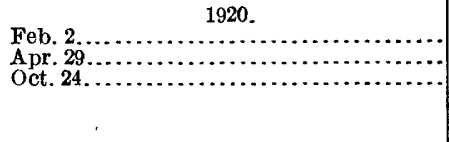 & $\begin{array}{rr}\text { Ft. } & \text { in. } \\
10 & 11 \\
7 & 8 \\
10 & 4\end{array}$ \\
\hline
\end{tabular}

O140. Little Landers Colony, NW. $\frac{1}{4}$ sec. 1, T. 19 S., R. 2 W., Tia Juana Valley.

[Drilled well, 30 feet deep, 12 inchesin diameter. Bench mark: Top of casing, 1 foot 2 inches below surface, 52.22 feet above sea level. Water-Supply Paper 446, Table 30, p. 129, and P1. XXXVI.]

\begin{tabular}{|c|c|c|c|}
\hline Date of measurement. & $\begin{array}{l}\text { Depth } \\
\text { of water } \\
\text { level } \\
\text { below } \\
\text { bench } \\
\text { mark. }\end{array}$ & Date of measurement. & $\begin{array}{l}\text { Depth } \\
\text { of water } \\
\text { level } \\
\text { below } \\
\text { bench } \\
\text { mark. }\end{array}$ \\
\hline 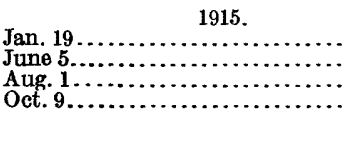 & $\begin{array}{rr}F t . & \text { in. } \\
6 & 3 \\
2 & 8 \\
3 & 3 \\
3 & 10\end{array}$ & 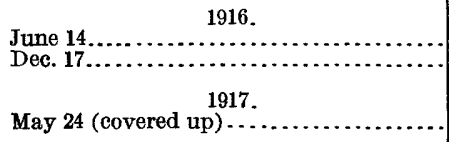 & $\begin{array}{rr}F t . & \text { in. } \\
2 & 2 \\
2 & 5\end{array}$ \\
\hline
\end{tabular}

O140a. Mrs. A. W. Jackson, near center of sec. 1, T. 19 S., R. 2 W., Tia Juana Valley.

[Drilled well, 18 feet deep; lift, gasoline engine and centrifugal pump; used for irrigation and domestic purposes. Bench mark: Top of board casing, 6 inches above surface. Companion well to O140. WaterSupply Paper 446, Table 30, p. 129.]

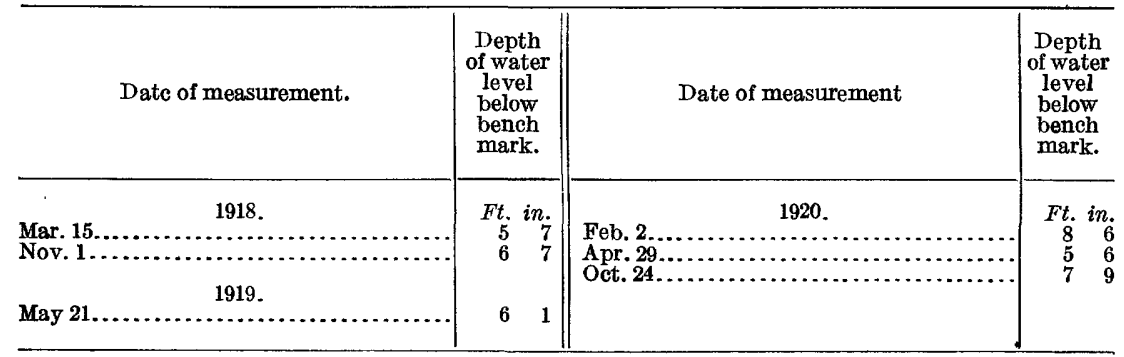





\section{INDEX.}

A.

Ainley, -, record of well of............... $\quad 81$

Alessandro, records of wells near........... 73-74

Allen, F. R., record of well of.............. 68

Alley, Charles, record of well of............ 58

Alvarado, F., record of well of............. $\quad 9_{2}$

Anaheim, record of well near............. 44-16

Andrews, T. D., record of well of........... 37

Arnez, M., record of well of ................ 25

Arnold, H., record of well of................ 69

Arnold, T. P., record of well of............ 114

Artesian Land \& Water Co., record of well of. . $\quad 22$

Atkins, Mrs. B. R., record of well of........ 120

Azusa, discharge of San Gabriel River near..

Azusa Irrigation Co., record of well of........

B.

Baisley, W. D., record of well of............

Baldwin, H. C., record of well of.

Baldwin Park, record of well near............

Ballantyne, James, record of well of. . .......

Bank of Norwalk, record of well of...........

Banta, G. B., record of well of..............

Barger, J. A., record of well of ..............

Barttell ranch, record of well on .............

Bates, Stanley, record of well of . . . ..........

Bates, Mrs., record of well of................

Bayley, william, record of well of ...........

Beach, G. S., record of well of ..............

Beck, - , record of well of................. 34-35

Bedell, Mrs., record of well of.............. 14

Bemis, A. W., record of well of............ 90

Bemis, Mrs. M. J., record of well of ..........

Bergstrom, L., record of well of.............

Bermudas, $\mathbf{H}$., record of well of..............

Bieley, Robert, record of well of.............

Bojorquez, $\mathbf{E}$. P., record of well of.......... 23-24

Bonsall, record of well near............... 127

B orden, John H., record of well of........... 43

Bowers, F., record of well of............... 53

Bowers, records of wells near............. 86,87

Boyd, J. F., record of well of . ............. 107

Bradley Bros., record of well of............ 63

Bright, Tony, record of well of............. 21

Brinkerhoff, $\boldsymbol{H}$. R., record of well of........ 25

Brockley, J. B., record of well of ........... 15

Brookside, records of wells near............ 113

Brown, C. P., record of well of............. 70

Brunson, L. A., record of well of........... 42

Bryn Mawr, records of wells near... 73,111-112,114

Buckmaster, J. C., record of well of......... 40

Buehler, F., record of well of.............. 115

C.

Cadd, J. F., record of well of.

Caldwell, A. B., record of well of........... 16-17 California, southern, map of part of. ....... In pocket. California State Hospital, record of well of... 120 Carmichael, J., record of well of.

Carrel, F. H., record of well of.
120
87

16
Page.

Carter, Crawford, record of well of . ......... 75-76

Cathcart estate, records of wells of .......... 64-66

Chamberlain, G. F., record of well of ........ 48

Champion, J., record of well of............. 109

Chinese gardeners, record of well of......... 13

Chino, record of well east of................. 70

Chula Vista, records of wells near.......... 149

Cienaga station, record of well near......... 22

Claremont, records of wells near........... 59-63

Clark, C. H., records of wells of . ........... 36-37

Clark, W. F., record of well of ............. 149

Coastal plain, depletion and replenishment of ground water in............ 9-10 previous work in ................... 5-6

Cole, H. H., record of well of . ............ 116

Colton, records of wells near.............. 71-72

Connelly, Eliza, record of well of........... 13

Cooley, E. M., record of well of ........... 120

Cooley, George M., records of wells of ....... 98-99

Cortelyou, G. A., record of well of.......... 24

County well at Ivy station, record of....... 22

at Lakeview, record of ............... 89

at San Luis Rey, record of.............. $\quad 129$

at Spadra, record of .................. $\quad 55$

near Alessandro, record of............. 73

near El Monte, record of............... 36

near Puente, record of ................ 50

Covina, record of well near................. 48

Crole, C. F., record of well of................ 100

Cunningham, R. F., record of well of ....... 120

Curtis, G. W., record of well of ........... 120

Curtis, R. T., record of well of . .......... 114

Cutting, C., record of well of............... 99

Cuyamaca Water Co., records of wells of. 142, 146, 147

D.

Deacon, Sidney, record of well of

55

Dennison, J. R., record of well of ............ $\quad 57$

Depletion of ground water, causes of........ 7

Dickson, James, record of well of ........... $\quad 96$

Dinsmore, J. H., record of well of........... 135

Doheny, E. L., record of well of ............ 20

Drew, H. S., record of well of............. 120

Drew, record of well near................ $\quad 116$

E.

Eason, W. M., record of well of ............ $\quad 81$

East Highlands, record of well near.......... 103

El Cajon, record of well near................ 148

Elliot, A., record of well of................. 39

Ellis, Arthur J., work of................. 127

El Monte, records of wells near............. 34-39

El Monte ranch, record of well on ............. 146

Emery, E. M., record of well of............ 120

Escondido Mutual Water Co., record of well of 133

Esler, B. T., record of well of.............. 102

Estudillo, José G., record of well of . ......... 87

Ethanac, records of wells near. ............ 77-78

Explanation of records.................. 10-12 
F.

Fairview Hotel, record of well of

Fickewith, E., record of well of.

Field, Dexter, record of well of.

Firth, Emil, record of well of.

Fisk, O. J., records of wells of ........ 111, 114

Flood water, conservation of............... 6-7

Flowing wells in San Bernardino Valley,

records of pressure in ......... 117-119

Fluctuation of water table, causes of ........ 6

Foothill belt, depletion and replenishment of ground water in.............. \& 8

previous work in ................... 5

Forman, Charles, records of wells of........ 130-131

Foster, records of wells near . . ........... 143-144

Fowler, A. C., record of well of. ........... 112

Fowler, G. J., record of well of............. 102

Fredericks, Alfonso, record of well of........ 150

Freer, Jackson, records of wells of........... 38

French, W. J., record of well of............ 120

Frink Bros., record of well of ............. 115

G.

Gage Canal Co., well record supplied by ..... 121-126 Gansnor \& Renwick, record of well of....... 115

Gardena, record of well near............... 16

Gardner, H. E., record of well of........... 120

Garland estate, record of well of........... 105

Garrigan, J. E., record of well of............ 85

Gay, M. R., records of wells of.......... 108, 120

Gay estate, record of well of. ............. 146

Goodman, Jane C., record of well of......... 100

Green, Mrs. Sarah, record of well of......... 93

Gregory, A., record of well of.............. 109

Ground water, source of supply of ..........

Gurado, E., record of well of

H.

Haley, 一, record of well of................

Ham, H. H., record of well of.

Hammel \& Decker, record of well of.........

Harford, Mrs. I. R., record of well of........

Harger, K. D., record of well of..............

Harkness, L. V., record of well of...........

Harlem Springs, records of wells near...... 100-102

Harmon, S. W., record of well of ........... 92

Harris, H. J., record of well of. ............. 17

Harris, O. W., record of well of............ 120

Hart, Albert, record of well of . ............ 96

Haslam, W. S., record of well of............ 83

Haws, Mrs., record of well of............... 101

Haws \& McKinley, record of well of ........ 100

Hayes, C. L., record of well of.............. 106

Heinze, H., record of well of ................ 49

Hemet, records of wells near........... 84-85,86

Hertel, Mrs. Emelie, record of well of....... 21

Hewitt, Mrs. Ruby, record of well of........ $\quad 86$

Hicks, S. E., record of well of.............. 54

Higgins, Dal, ranch, record of well on....... 128

Elinkley, N. B., estate, record of well of..... 73

Hislop, -, record of well of.............. 31

Holcomb, E. L., record of well of . ......... 120

Hollywood, records of wells near........... 28-29

Holmes, C. A., record of well of............ 87

Hopkins, H. R., record of well of........... 63

Howard Summit, record of well near....... 19-20

Hows, Mrs., record of well of.............. 118

Huebsch, W. J., record of well of.......... 68

Hurlbut, - , record of well of ............. 29-30
Page.

Icovich, L. H., record of well bf............ 140 Idlewild, records of wells near...... 99, 115, 116-117

Irrigation, water for, source of............ 5 water from, as source of ground water.. 7

Ivy station, record of wells near........ 22,24-25

J.

Jackson, Mrs. A. W., record of well of........ 151

Jackson, S. A., record of well of............ 91

Johnson, A. P., record of well of........... 19-20

Johnson, George W., record of well of....... 141

Johnson, S. H., record of well of............ 95

Jorgensen, C. C., record of well of........... $\quad 17$

Judson, F. M., record of well of............ 137

K.

Kane, M. P., record of well of............. $\quad 23$

Kearney, Mark, record of well of........... $\quad 140$

Kelly, S. F., record of well of............. 94

Kidson, Richard, record of well of ......... 12

Kincaid, L. C., records of wells of........... 148

Kumler, H. R., record of well of........... 86

Kuntz, W. H., record of well of............ 42

I.

Lakeside, records of wells near........ 142, 144-146

Iakeview, records of wells near............ 88-89

Lancaster, J. W., record of well of .......... 74

Landreth, C. A., record of well of........... 41

Law, J. A., record of well of.............. 34

Lee, Charles H., work of ................ 127

Lee \& Gilmore, records of wells of.......... 69

Lemon, record of well near............... $\quad 53$

Lenanon, A., record of well of............. 115

Linastruth, B., record of well of........... 66

Iindenberg, William, record of well of....... 108

Lindenberger, H. H. H., record of well of...... 81

Little Landers Colony, record of well of..... 151

Lodge, H. E., record of well of............. 28

Lofland, Fred W., record of well of......... 14

Long, Ben, records of wells of............. 18

Lordsburg, record of well near............. 58-59

Los Angeles, precipitation at, graph showing $\quad 8$

records of wells in ............. 12, 13-15, 20-21

Lossman, C., record of well of............. 75

Lyons, L., record of well of.............. 103

Lytle, J. H., record of well of.............. 93

M.

McClain, John, estate, record of well of ...... 32

McClure, Mrs., record of well of............ 36

McCollum, I.. record of well of. ........... 31

McCoy, John, record of well of............ $\quad 34$

McDonald, Albert, record of well of......... 88

McIntosh, R. P., records of wells of ...... 104, 105

Mansfield, S., record of well of............. 111

Martin, Emmet, record of well of............ 108

Massey, -, record of well of ............. 58-59

Meeker, Dr., record of well of ............. $\quad 120$

Mendenhall, W. C., work of ............. 5,6,10

Menifee School, record of well of........... $\quad 80$

Menifee Valley, records of wells in.......... $\quad 80$

Mentone, records of wells near........ 103, 104-105

Meyers, H. S., record of well of ............ 138

Meyers, Mrs., record of well of.............. 67

Miles, H. A., record of well of............ 139

Miller, Willis, record of well of ............ 106 
Page.

Mission Valley, records of wells of ......... 139, 140
Moneta, records of wells near.............. $16-19$

Monseratte rancho, record of well on........ 128

Moro, Paul, record of well of.............. 76

Moro, Santos, record of well of............. 75-76

Morris, Charles, record of well of............ 120

Morris, Mrs. F., record of well of........... 113

Murray, Mrs., record of well of............ 117

\section{N.}

Neff, J. B., acknowledgment to............ well of, graph showing fluctuation in.... record of ........................ 44-46

Nelson, E. G., record of well of ............ 70

Nestor, record of well near............... 150

Newport, Wiliam, records of wells of........ 78,80

Nichols, W. A., records of wells of ......... 110

Niles, William, record of well of . . ......... 26-27

Norwalk, records of wells near............ 43-44

Norwalk Builders Association, record of well of . .............................

Norwood, E., record of well of

o.

Ontario Water Co., record of well of . ........ 59-60

Orric, - , record of well of ................. 92

Otay, records of wells near............ 149,150

P.

Pala, record of well near................. 128

Palmer, S. E. A., record of well of .......... 120

Palms, records of wells at............... 23-24

Parker, Mrs., record of well of............ 113

Pasadena, records of wells in .............. 29-31

Pattee \& Nye, record of well of........... 102

Patterson, Miss T., record of well of......... 82

Patton, records of wells near................ 98-99

Perris, records of wells near.......... 74-77, 78-79

Persons, Mrs. Sadie G., record of well of..... 53

Philbrook, G. E., record of well of........ 141, 144

Phillips, C. S., record of well of............. 75

Pomona, records of wells near............ 63-70

Pooles, Fred, record of well of ........... 120

Poorman, Edward, record of well of........ 74

Post \& Lockhart, record of well of.......... 19-20

Puente, records of wells near.............. 49-50

Purpose of the investigation............... $5-6$

\section{R.}

Rain, ground water supplied by

Ramona, records of wells near..

Redlands, records of wells near....... 105-111,115

Reed, Dr. A. R., record of well of........... 63

Reese, Dr., record of well of.............. 78-79

Reimers, R., record of well of............. 69

Renfro, G. B., records of wells of........... 33

Renwick, G., record of well of ........... 90

Reynolds, M. D., record of well of......... 91

Rhodeos, J., record of well of. ............ 150

Richmond, Edmund E., record of well of.... 132

Ritter, M., record of well of................ 35

Riverside Trust Co., record of well of....... 99

Riverside Water $\mathrm{Co}$., records of wells of. . 72, 118-119

Riverview, record of well near.............. 147

Roberts place, record of well on .......... 136

Robertson, W. B., rncord of well of......... 102

Rogers. C. W, record of well of.
Romick, J. W., record of well of............ Page.

Ronzone, S., record of well of............ 107

Rowland, William, records of wells of..... 51-52

Rowland, records of wells near. . . . . . . . . 51-52

S.

San Antonio Water Co., record of well of.....

San Bernardino, precipitation at, graph show-

ing ......................... 88

records of wells near............. 71, 72,

$90-96,117-119,121-126$

San Bernardino Valley, depletion and replenishment of ground water in...... $7-8$

discharge of Santa Ana River at entrance to......................... 9

previous work in ................... 5,10

San Diego, Old Town, record of well near.... 140 San Diego Construction Co., record of well of. . 149

San Diego County, records of wells in...... 127-151

previous work in.................. 126

San Diego River at Lakeside, record of ..... 145

San Dimas, records of wells near.......... 55-57

San Francisco Savings Union, record of well of......................... 147

San Gabriel, records of wells near.......... 32

San Gabriel River, discharge of, graph showing ..............................

discharge of, near Azusa, Calif. .......... San Jacinto, precipitation at, graph showing. San Jacinto Valley, depletion and replenishment of ground water in....... 10

previous work in .................... 6,11 San Luis Rey, records of wells near....... 129-133 San Pasqual, records of wells near........ 136-139 Santa Ana River, discharge of, at entrance to San Bernardino Valley....... 8

discharge of, graph showing........... 8 Santa Fe ranch, record of well on......... 134-135 Santa Fe Springs, records of wells near..... 42 Santa Ysabel Creek at San Pasqual, record of........................... 139

Santee, record of well near.......... 143,146,147 Savannah, records of wells near............ 33 Scope of the investigation............... $5-6$ Scott, H. R., record of well of............ 120 Scott, J. P., record of well of .............. 101 Series of wells measured.................. 10-12 Sesma, Jose, record of well of.............. 24 Sesma, Mrs., record of well of............... 28 Severence, M. S., record of well of.......... 97, 120 Severence, W. R., record of well of......... 97 Sharp, J. W., record of well of............. 42 Shaw, C. A., record of well of............. 109 Sherman, records of wells near........... 25-27 Showers, Mrs., record of well of ........... 21 Silvey, George, record of well of........... 58-59 Slack, H. A., record of well of............. $\quad 29$ Slack, -, record of well of................ 103 Slauson, record of well near............... 13 Smith, James, record of well of............ 116 Smyres, -, record of well of.............. $\quad 85$ Sores, W. D., record of well of............. 120 Sources of ground water.................. $6-7$ Spadra, records of wells near.............. 54-55 Stiles, E. J., record of well of............... 96 Stones, H. N., record of well of........... 95 Streams, ground water supplied by........ $6-7$ 
Summers, W. G., record of well of........... Page.

Sumner ranch, record of well on............ 144

Sunnyside, records of wells near............ 148

Sunny Slope station, record of well near.... 31

Sutherland, N., record of well of........... 120

Swarthout, N. M., record of well of ......... 93

Sylvera, Mrs. S. W., record of well of....... 111

T.

Ternescal Water Co., record of well of........

Terry, William, record of well of............

Theland, Mrs. Mary, record of well of........

Thomas, Milton, record of well of...........

Thomas, W. A., record of well of............

Thum, H., record of well of

Thum, William, record of wellof

Tia Juana Valley, records of wellsin ........ 150-151

Tieg, Mrs., record of well of ............... 68

Till, Demmy, record of well of............ 14

Titus ranch, record of well on............. 31

Torbert, W. S., record of well of............. 32

Tustin, precipitation near, graph showing...

U.

Ummerman, Father, record of well of

U.S. Geological Survey, record of well of...

Urbita Hot Springs Co., record of flowing well of.

\section{V.}

Vache, E., record of well of

Valencia, records of wells near ...............

Valley of southern California, defined. ......

Van Leuven, E. F., record of well of..
Vigus, Mrs. Mary, record of well of.

Page.

Vineland, record of well near.............. 47

W.

Walker, Mrs. Maud F., record of well of ..... 84

Wallace, R. A., record of well of ........... $\$ 1$

Walnut, record of well near............... 53

Ward, -, record of well of................ 34-35

Ward, Mills \& Co., record of well of......... 104

Washington School, record of well of ....... $\quad \mathbf{1 2 0}$

Waters, E. E., record of well of............ 77

Well No. 42, fluctuation in, graph showing.. 8

Well No. 72, fluctuation in, graph showing.. 11

Wells not measured since 1913, records of .... 120

Westmyer, C. H., record of well of .......... 120

White, D. W., record of well of ........... 120

White, J. J., record of well of . .............67-68

Whittler, record of well near............... 39-41

Whitworth, J. H., record of well of ......... 25

Wilcox, F. E., record of well of ............ 29-30

Wilhelm, L., record of well of ............. 81

Williams, L. H., record of well of.......... 101

Williams well, graph showing fluctuation in. 8

record of . . . . . . . .

Wilson, F. E., record of well of........... 32

Winchester, records of wells near.......... 81-83

Winship, F. M., record of well of ........... 149

Woodbridge, -, record of well of.......... $\quad 90$

Y.

Yorba, B., record of well of...............

z.

Zader, W. L., record of well of.

120 



